\title{
THE SYNTHESIS OF CARBOHYDRATES FOR THE TREATMENT OF DISEASE
}

\author{
By \\ Emma Marie Dangerfield
}

\begin{abstract}
A thesis
submitted to the Victoria University of Wellington

in fulfilment of the requirements for the degree of

Doctor of Philosophy
\end{abstract}

Victoria University of Wellington

2011 



\section{Abstract}

In this thesis I investigated two aspects of glycobiology. In the first, I investigated the potential of $\alpha$-GalCer analogues to be used in cancer immunotherapy. Two 4deoxy $\alpha$-GalCer analogues, with either a sphinganine or a sphingosine base, were synthesised using a convergent strategy. The $\alpha$-GalCer sphinganine derivative was synthesised in 14 steps from D-arabinose, and in an overall 13\% yield. The $\alpha-$ GalCer sphingosine analogue was synthesised in 13 steps also in $13 \%$ yield. Biological analysis revealed that both 4-deoxy analogues possessed comparable activity to $\alpha$-GalCer in mice, however demonstrated significantly reduced hNKT cell activity. The reduced activity was attributed to species-specific differences in iNKT cell glycolipid recognition rather than reduced CD1d presentation. From these results we suggest that glycolipids developed for potent CD1d-iNKT cell activity in humans should contain a ceramide base with the 4-hydroxyl present.

The second part of this thesis focused on protecting group free methodology for the synthesis of sugar mimetics that have proven potential as glycosidase inhibitors. In this work I developed an efficient, high yielding and diastereoselective strategy for the synthesis of a number of five and six membered azasugars. This strategy utilises two novel reaction methodologies. The first enabled the stereoselective formation of cyclic carbamates from olefinic amines, the transition states controlling the stereoselectivity during this reaction are discussed. The second reaction facilitated the synthesis of primary amines without the need for protecting groups, the scope of this reductive amination methodology is also investigated. The five membered azasugars 1,4-dideoxy-1,4-imino-Dxylitol, 1,4-dideoxy-1,4-imino-L-lyxitol, 1,4-dideoxy-1,4-imino-L-xylitol and 1,2,4-trideoxy-1,4-imino-L-xylitol were prepared in 5 steps, in good overall yields (57\%, 55\%, 54\% and 48\% respectively), and without the need for protecting groups. The six membered azasugar DGJ was prepared over six steps in $33 \%$ yield using similar methodology. The synthesised compounds were also tested for anti-tubercular activity using a BCG alamar blue assay. 



\section{Acknowledgements}

Many people have contributed to this $\mathrm{PhD}$ journey, and without their help the last three years would not have been the same. I would like to begin by thanking Drs Bridget Stocker and Mattie Timmer for their guidance and supervision. Thank you for encouraging, supporting and believing in me. I have really appreciated your dedication and commitment to teaching me and I admire your pioneering spirits. I would like to thank Dr Ian Hermans for input and advice and especially for teaching me the language of immunology. Also thanks to Prof Graham LeGros for the various pep talks and for encouraging me to be true to my own values and goals.

Thanks to Anna, Ashna, Janice, Janelle, Hilary, Gert, Steph, Stefan, Jessie, Cat, Lynton, Ben and Greg, the past and present students of the immunoglycomics research group. I have really valued the great conversations and discussions about work and life in general, you make the chemistry lab a great place to be. Thanks to Debs and Sara for helping me find my way around the immunology labs and to all the members of the vaccine research group for creating a great learning environment. I am very grateful to Rob Weinkove for conducting the human iNKT cell proliferation assay, to Fenella Rich and Dr Joanna Kirman for their help with the BCG assay, and to René McLaughlin for teaching me how to culture human DCs. I would specifically like to mention the help of our collaborators, Assoc Prof Rod Dunbar and Dr Anna Brooks (Auckland University), who provided me with the human $\mathrm{T}$ cell clones, and also the Tertiary Education Commission who supported me financially throughout the course of my $\mathrm{PhD}$.

I would also like to thank the non-scientist friends and family who have travelled with me on this journey. Your input has been invaluable and has given me perspective as I focus on the details and intricacies of my research. To my Mum, Dad, and sister for always encouraging me to do my best, thank you for all your love, support, guidance and friendship. Finally I would like to thank Chris, who has been my companion throughout. Your continuing and unwavering support has been a source of strength and encouragement. You have walked this journey with me and this thesis is part of your story too. 



\section{Preface}

This thesis is composed of seven chapters that describe the chemistry and biology of glycoconjugates and carbohydrates that can inhibit the metabolism of this important class of compound. In chapter one, an introduction into the studies undertaken in chapters two through seven is given. Here the reader is introduced to the iNKT cell ligand $\alpha$-GalCer (1, Figure 1). In addition the therapeutic value of azasugars as glycosidase inhibitors is presented.

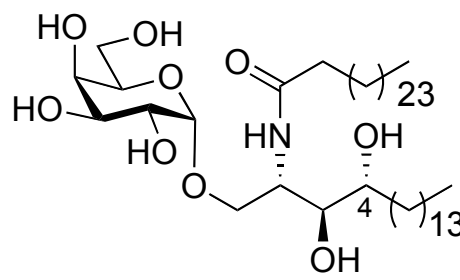

1, $\alpha$-GalCer (KRN7000)

Figure 1. The iNKT cell ligand $\alpha$-GalCer.

The three major goals of this thesis were firstly, to understand the glycolipid structural components required for potent iNKT cell activation. Specifically we wanted to understand the importance of the 4-hydroxyl for glycolipid activity. Secondly, to develop methodology that enabled azasugars to be synthesised without using protecting groups. Thirdly, to investigate the anti-tubercular activity of compounds described in chapters four to six.

Chapters two and three focus on understanding the importance of the 4-hydroxyl for iNKT cell activity. In chapter two, the syntheses of two 4-deoxy $\alpha$-GalCer analogues, $\mathbf{2}$ and $\mathbf{3}$ (Figure 2), are described. The 4-deoxy analogues $\mathbf{2}$ and $\mathbf{3}$ were each synthesised in $13 \%$ yield over 14 and 13 steps respectively. In chapter four the biological activity of these 4-deoxy analogues, compared to $\alpha$-GalCer was investigated. I found that the 4-hydroxyl was not a requirement for potent iNKT cell activity in mice, however, was vital for human iNKT cell activation. 


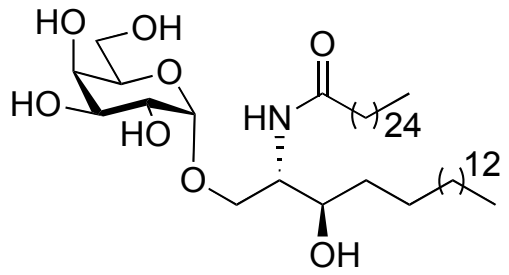

$\alpha$-GalCer analogue with sphinganine lipid 2

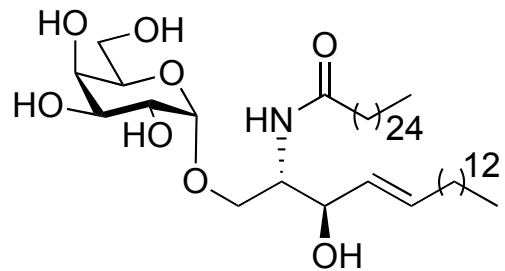

$\alpha$-GalCer analogue with sphingosine lipid 3

Figure 2. The two 4-dexyo $\alpha$-GalCer analogues synthesised in chapter two.

Chapters four to six focus on developing methodology for the protecting group free synthesis of azasugars. In chapter four, two new reaction methodologies were developed that enable azasugars to be synthesised without using protecting groups. These reactions were a reductive amination, to synthesis primary amines directly from aldehydes, and a stereoselective carbamate annulation. The scope of the reductive amination was investigated in chapter five. In general this methodology was widely applicable to the synthesis of a variety of primary amines from aldehyde precursors. In chapter six the scope and application of the carbamate annulation for the synthesis of five and six membered azasugars was investigated. When the methodology was used to synthesise five membered azasugars the carbamate annulation was stereoselective ( $>20: 1$ d.r. in all reactions carried out). When the methodology was extended to six membered azasugars the diastereoselectivity was reduced. Overall the protecting group free methodology was employed to synthesise five azasugars from carbohydrate starting materials. The azasugars synthesised and the overall yields obtained for their synthesis are depicted in figure 3. 
<smiles>OC[C@H]1NC[C@@H](O)[C@@H]1O</smiles>

1,4-Didexoy-1,4-imino-D-xylitol 5 Steps from D-xylose overall yield: $55 \%$<smiles>OC[C@@H]1NCC(O)[C@H]1O</smiles><smiles>OC[C@@H]1NC[C@@H](O)[C@H]1O</smiles>

1,4-Didexoy-1,4-imino-L-lyxitol

5 Steps from D-lyxose overall yield: $55 \%$<smiles>OC[C@@H]1NCC[C@@H]1O</smiles>

\section{1,4-Didexoy-1,4-imino-L-xylitol 1,2,4-Trideoxy-1,4-imino-L-arabinitol 5 Steps from D-arabinose overall yield: $54 \%$ \\ 5 Steps from 2-deoxy-D-ribose overall yield: $48 \%$}<smiles>OC[C@H]1NC[C@@H](O)[C@H](O)[C@@H]1O</smiles>

\section{Deoxygalactonojirimycin}

Six steps from D-galactose overall yield: $33 \%$

Figure 3. Azasugars synthesised in chapters four and six using the protecting group free methodology developed in this thesis.

In chapter seven the anti-tubercular activity of the compounds described in chapters four to six were investigated. In this chapter an established BCG growing assay was optimised and used to examine the activity of the compounds. Most compounds did not exhibit inhibitory activity, however, 1(diphenylmethyl)amino-pent-4-ene-2,3-diol exhibited modest inhibitory activity. 



\section{Table of contents}

CHAPTER 1:

Introduction

1.1 General introduction 1

1.2 Glycolipid adjuvants for cancer immunotherapy 13

$\begin{array}{ll}1.3 \text { The history and synthesis of azasugars } & 30\end{array}$

1.4 Thesis outline 43

CHAPTER 2:

The Synthesis of $\alpha$-GalCer Analogues 51

2.1 Introduction 51

2.2 Synthesis of $\alpha$-GalCer Analogues $\quad 52$

2.3 Conclusion $\quad 58$

$\begin{array}{ll}2.4 \text { Experimental } & 59\end{array}$

$\begin{array}{ll}2.5 \text { References } & 77\end{array}$

CHAPTER 3:

Biological Testing of $\alpha$-GalCer Analogues $\quad 79$

$\begin{array}{ll}3.1 \text { Introduction } & 79\end{array}$

$\begin{array}{ll}3.2 \text { Results } & 80\end{array}$

$\begin{array}{ll}3.3 \text { Discussion } & 85\end{array}$

$\begin{array}{ll}3.4 \text { Conclusion } & 88\end{array}$

$\begin{array}{ll}3.5 \text { Experimental } & 89\end{array}$

$\begin{array}{ll}3.6 \text { References } & 93\end{array}$

CHAPTER 4:

Protecting Group Free Synthesis of a Five Membered Azasugar 95

4.1 Introduction 95

4.2 Results and Discussion 96

4.3 Conclusion 103

4.4 Experimental 103

$\begin{array}{ll}4.5 \text { References } & 109\end{array}$

CHAPTER 5:

Reductive Amination Methodology for the Synthesis of Primary Amines 111

$\begin{array}{ll}5.1 \text { Introduction } & 111\end{array}$

5.2 Results and Discussion $\quad 112$

$\begin{array}{ll}5.3 \text { Conclusion } & 121\end{array}$

5.4 Experimental 121

5.5 References 131

CHAPTER 6:

Investigations into the Carbamate Annulation Reaction for the Synthesis

of Five and Six Membered Azasugars 133

6.1 Introduction 133

6.2 Results and Discussion 134

$\begin{array}{ll}6.3 \text { Conclusion } & 153\end{array}$

6.4 Experimental 154

$\begin{array}{ll}6.5 \text { References } & 170\end{array}$ 
CHAPTER 7:

Anti-tubercular Activity of Azasugars and Linear Alkenylamines

7.1 Introduction

7.2 Results and Discussion

7.3 Experimental

7.4 References

APPENDIX

NMR Spectra 


\section{List of Abbreviations}

\begin{tabular}{|c|c|c|c|}
\hline \multicolumn{2}{|c|}{$\alpha$-GalCer $\alpha$-galactosylceramide } & \multirow[t]{2}{*}{ GD1b } & \multirow{2}{*}{$\begin{array}{l}\text { Gal } \beta 1-3 \text { GalNAc } \beta 1 \text { - } \\
4(\text { Neu5Ac } \alpha 2-8 \text { Neu5Ac } \alpha 2-\end{array}$} \\
\hline Ac & acetyl & & \\
\hline $\mathrm{AcOH}$ & acetic acid & & 3)Gal $\beta 1$-4GlcCeramide \\
\hline $\mathrm{AG}$ & arabinogalactan & GM1 & Gal $\beta 1-3$ GalNAc $\beta 1-$ \\
\hline APC & antigen presenting cells & & 4(Neu5Ac $\alpha 2-3)$ Gal $\beta 1-$ \\
\hline APC & fluorophore: & & 4GlcCeramide \\
\hline & allophycocyanin & GMCSF & granulocyte-macrophage \\
\hline aq. & aqueous & & colony-stimulating factor \\
\hline AraT & arabinosyltransferase & GSL & glycosphingolipid \\
\hline $\mathrm{BCG}$ & Bacillus Calmette-Gérin & GT1b & Neu5Ac $\alpha 2-3$ Gal $\beta 1-$ \\
\hline $\mathrm{Bn}$ & benzyl & & 3GalNAc $\beta 1-4(\mathrm{Neu} 5 \mathrm{Ac} \alpha 1-$ \\
\hline Boc & tert-butyloxycarbonyl & & 8Neu5Ac $\alpha 2-3)$ Gal $\beta 4$ Glc \\
\hline br & broad & & Ceramide \\
\hline $\mathrm{Bz}$ & benzoyl & $\mathrm{hDC}$ & human DC \\
\hline $\begin{array}{l}\text { Calcd. } \\
\text { CD }\end{array}$ & $\begin{array}{l}\text { calculated } \\
\text { cluster of differentiation }\end{array}$ & HMBC & heteronuclear multiple \\
\hline COSY & correlated NMR spectrum & HMPA & hexamethylphosphoramide \\
\hline d & doublet & hNKT & human iNKT \\
\hline dd & doublet of doublets & HRMS & high-resolution mass \\
\hline $\mathrm{DAB}$ & 1,4-dideoxy-1,4-imino-D- & & spectrometry \\
\hline DBU & $\begin{array}{l}\text { arabinitol } \\
1,8 \text {-diazabicyclo[5.4.0] }\end{array}$ & HSQC & $\begin{array}{l}\text { heteronuclear single } \\
\text { quantum coherence }\end{array}$ \\
\hline $\mathrm{DC}$ & $\begin{array}{l}\text { undec-7-ene } \\
\text { dendritic cell }\end{array}$ & HT-2 & $\begin{array}{l}\text { murine T-helper cell- } \\
\text { derived line }\end{array}$ \\
\hline $\mathrm{DCM}$ & dichloromethane & $\mathrm{Hz}$ & hertz \\
\hline DGJ & deoxygalactonojirimycin & IFN & interferon \\
\hline GMII & golgi $\alpha$-mannosidase II & $\mathrm{iGb3}$ & isoglobotrihexosylceramide \\
\hline DMAP & 4-(dimethylamino)pyridine & IL & interleukin \\
\hline DMDP & $\begin{array}{l}\text { 2,5-dihydroxymethyl-3,4- } \\
\text { dihydroxypyrrolidine }\end{array}$ & IMDM & $\begin{array}{l}\text { Iscove's Modified } \\
\text { Dulbecco's Medium }\end{array}$ \\
\hline $\mathrm{DMF}$ & dimethylformamide & Imid. & imidazole \\
\hline DMSO & dimethyl sulfoxide & iNKT & invariant natural killer $\mathrm{T}$ \\
\hline DNA & deoxyribonucleic acid & $i \operatorname{Pr}$ & iso-propyl \\
\hline DPA & arabinofuranosyl-1-mono & IR & infrared spectroscopy \\
\hline & phosphoryl-decaprenol & $i . v$. & intra venous \\
\hline EDCI & 1-ethyl-3-(3- & $J$ & coupling constant \\
\hline & dimethylaminopropyl) & $\mathrm{KO}$ & knock out \\
\hline & carbodiimide & LSD & lysosomal storage disorder \\
\hline eq. & equivalents & $\mathrm{m}$ & multiplet \\
\hline ER & endoplasmic reticulum & $\mathrm{mDC}$ & mouse DC \\
\hline ESI & electron spray ionization & MDR & multi-drug resistance \\
\hline Et & ethyl & $\mathrm{Me}$ & methyl \\
\hline FITC & fluorescein isothiocyanate & $\mathrm{MHC}$ & major histocompatibility \\
\hline $\mathrm{Gb} 3$ & globotrihexosylceramide & & complex \\
\hline & & $\mathrm{MHz}$ & mega hertz \\
\hline & & MIC & $\begin{array}{l}\text { minimum inhibitory } \\
\text { concentration }\end{array}$ \\
\hline
\end{tabular}




\begin{tabular}{|c|c|c|c|}
\hline $\begin{array}{l}\min . \\
\mathrm{mNKT}\end{array}$ & $\begin{array}{l}\text { minutes } \\
\text { mouse iNKT }\end{array}$ & PNP & purine nucleoside \\
\hline MOM & methoxymethyl & ppm & parts per million \\
\hline $\mathrm{Mp}$ & melting point & $p \mathrm{TsOH}$ & para-toluenesulfonic acid \\
\hline mRNA & messenger ribonucleic acid & $\mathrm{RBC}$ & red blood cell \\
\hline Ms & mesyl & RPMI & Roswell Park Memorial \\
\hline$m / z$ & mass to charge ratio & & Institute \\
\hline \multirow[t]{3}{*}{ NADPH } & nicotinamide adenine & $\mathrm{rt}$ & room temperature \\
\hline & dinucleotide phosphate & $\mathrm{s}$ & singlet \\
\hline & hydride & sat. & saturated \\
\hline NBS & $N$-bromosuccinimide & SE & Standard Error \\
\hline NIS & $N$-iodosuccinimide & $t$ & triplet \\
\hline NK & natural killer & TAB & tween albumin broth \\
\hline \multirow[t]{2}{*}{ NMO } & $N$-methylmorpholine- $N$ - & $\mathrm{Tb}$ & tuberculosis \\
\hline & oxide & $t$-Bu & tert-butyl \\
\hline \multirow[t]{2}{*}{ NMR } & nuclear magnetic & TCR & $\mathrm{T}$ cell receptor \\
\hline & resonance & TES & triethylsilane \\
\hline \multirow[t]{2}{*}{ OADC } & oleic albumin dextrose & TFA & trifluoroacetic acid \\
\hline & catalase & THF & tetrahydrofuran \\
\hline Obsd. & observed & TLC & thin layer chromatography \\
\hline \multirow[t]{2}{*}{ PBMC } & peripheral blood & TLR & toll-like receptor \\
\hline & mononuclear cells & $\mathrm{Tf}$ & trifluoromethanesulfonyl \\
\hline PBS & phosphate-buffered saline & TNF & tumour necrosis factor \\
\hline PE & phycoerythrin & $\operatorname{Tr}$ & triphenylmethyl \\
\hline PerCP & $\begin{array}{l}\text { peridinin-chlorophyll } \\
\text { proteins }\end{array}$ & VEGF & $\begin{array}{l}\text { vasculature endothelial } \\
\text { growth factor }\end{array}$ \\
\hline $\mathrm{Ph}$ & phenyl & XDR & extreme-drug resistance \\
\hline
\end{tabular}




\section{Chapter 1: Introduction}

\subsection{General introduction}

Glycans are vital components of all cells. Their role in biology, from energy storage to cellular recognition, makes them vital to the existence of life as we know it. ${ }^{1}$ Glycoconjugates are one of the most complex biopolymers, due to their vast monomeric structural diversity and the number of connection sites possessed by each individual unit. As our understanding of the glycome and the biological functions of carbohydrates increases, so does our ability to harness their potential for the treatment of disease. ${ }^{2}$

The study of modern carbohydrate chemistry began in 1891, with Emil Fischer's assignments of the relative configurations of the monosaccharides. ${ }^{3,4}$ Prior to this, glucose and galactose were recognised as similar but distinct sugars, yet very little was known about their structure. ${ }^{5}$ Emil Fischer's work was fundamentally important to the field of carbohydrate chemistry and in 1902 he was awarded the Nobel Prize in Chemistry for his work on sugars and purines. ${ }^{6,7}$ Over the next 50 years, the field of carbohydrate chemistry continued to evolve and flourish, with some of the most significant achievements being: the discovery of the first naturally occurring branched chain sugar, hamamelose (K. Freudenberg); investigations into the cyclic/acyclic nature of hydroxylated aldehydes and research into glycosidase enzymes (B. Helferich); and the application of methylation analysis to analyse disaccharides (N. Haworth). ${ }^{5}$

In the 1950s, newly introduced chromatographic and NMR techniques made it possible to follow the progress of complex carbohydrate reactions, and during this 
period of sugar research the importance of the carbocation intermediate, during glycosylation reactions, was realised and exploited, thus enabling more controlled structural modifications of carbohydrates to be made. A number of sugar analogues were synthesised during this period including $C$-glycosidic, branched chain, unsaturated derivatives and carbohydrates with amino-, thiol-, or halogenosubstituents replacing one or more of the hydroxyl groups on the carbohydrate ring. The syntheses of these modified carbohydrates was largely driven by the discovery that many modified sugars were not only metabolites, produced by microorganisms, but also, in many instances, were biologically active. ${ }^{5}$

\section{Glycobiology}

As our structural and chemical understanding of carbohydrates has grown, so too has our comprehension of the role that carbohydrates play in biological systems. Since the late $19^{\text {th }}$ century, the first insights into the role of carbohydrates during fermentation marked the beginning of the glycobiology field. ${ }^{8,9}$ However, due to the highly complex nature of glycoconjugates, this field has often been overshadowed by genomic and proteomic research. ${ }^{10}$ Despite this, we now understand much about the function of carbohydrates in energy storage, intercellular adhesion, signal transduction and viral and bacterial cell-surface recognition. Glycans enable cellular recognition and communication, they help to distinguish prokaryotes from eukaryotes, and form major components of cell walls and peptidoglycans. Many eukaryote and prokaryote cells contain a glycocalyx, which sits outside the plasma membrane and consists of a myriad of carbohydrate rich molecules (Figure 1.1). These carbohydrate molecules are like chemical keys, carrying the information required for events such as regulated intercellular interactions. ${ }^{11}$ As biopolymers, glycoconjugates are one of the most complex, and the majority of these are bound to proteins (glycoproteins) or to lipid backbones (glycolipids). These carbohydrates, which protrude into the surrounding environment, provide binding sites for other cells, pathogens, antibodies and lectins (carbohydrate binding proteins). 


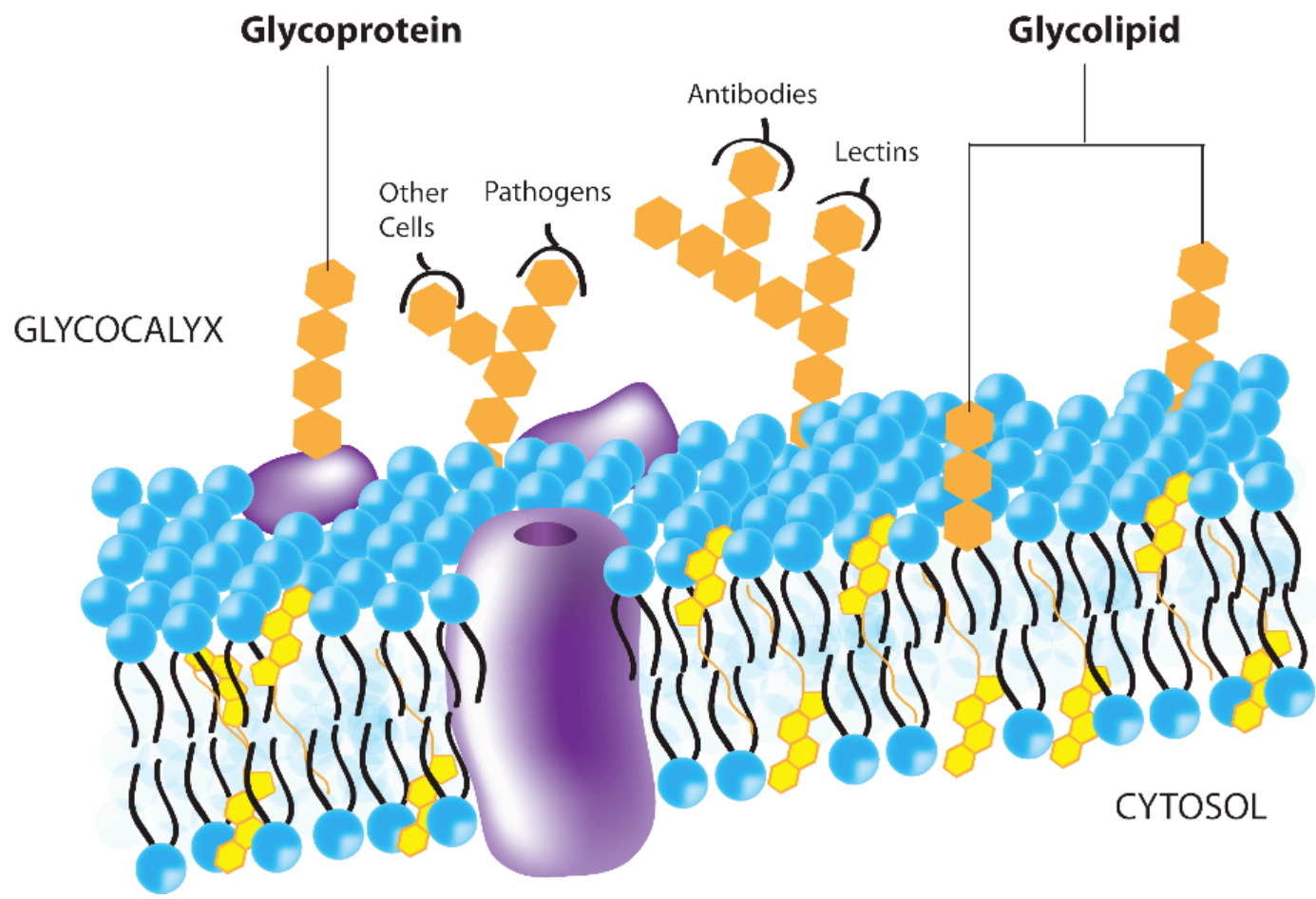

Figure 1.1. Cellular glycocalyx. Glycoproteins and glycolipids protrude from the cellular membrane into the surrounding environment. They provide binding sites for pathogens, such as viruses and bacteria, other cells, antibodies, and lectins.

The classical ABO blood group antigens provide an elegant example of the importance of extracellular glycans. Each of the classified antigens within the ABO blood group system are oligosaccharides found at the termini of glycoproteins, glycolipids and soluble oligosaccharides (Table 1.1). ${ }^{11}$ These antigens were first discovered on the surface of erythrocytes (red blood cells), however, they are also displayed by other tissues and human secretions. The ABO classification is based on the presence or absence of two antigens, $\mathbf{A}$ and $\mathbf{B}$, on the erythrocyte surface. ${ }^{12}$ In addition, there are two antibodies (gamma globulin proteins) anti-A and anti-B, which always occur in the plasma when the corresponding antigen is missing. If an oligosaccharide is not modified to the $\mathbf{A}$ or B type structures, the phenotype is called $\mathrm{O}$ and the surface antigen $\mathbf{H}$. These antigens are recognised by an antibody called anti-H. ${ }^{11}$ It is this knowledge which enables us to understand why, for example, a person of blood group $\mathrm{O}$ cannot receive blood from a person with type A blood, as the anti-A antibodies will cross react with the A antigens in the received blood, resulting in agglutination. 
Table 1.1. The ABO blood group system. ${ }^{11}$

\begin{tabular}{lcc} 
Phenotype of & Minimal determinant saccharide & $\begin{array}{c}\text { Antibodies found } \\
\text { in plasma }\end{array}$ \\
\hline (Blood group antigen) & Anti-B
\end{tabular}

Another important class of carbohydrate-specific binding protein are the lectins. Lectins selectively and reversibly bind saccharides, however, they do not possess catalytic activity nor are they products of an immune response. ${ }^{13}$ This heterogeneous group of oligomeric proteins has been implicated in diverse biological functions including cell adhesion, cell recruitment, intracellular 
trafficking and immune recognition. Lectins occurring in animals consist of three subgroups, the S-type lectins, the C-type lectins and the P-type lectins. ${ }^{11} \mathrm{C}$-type lectins are further classified into endocytic lectins, collectins and selectins. One group of important endocytic lectins are the mannose-binding proteins. These are soluble lectins present in mammalian serum and liver, which bind to oligomannosides on infectious microorganisms, resulting in the activation of the compliment system (made up of over 25 proteins), and the subsequent lysis of invading pathogens. ${ }^{13}$

Glycosphingolipids (GSLs), an important class of glycolipid, are components of essentially all types of animal and plant cell membranes. There are six series of glycosphingolipid that all contain a sphingoid base, most frequently ceramide (1, Figure 1.2), but possess different core oligosaccharides. ${ }^{14}$ The class sphingoid base encompasses over 100 different lipid amino alcohols with the three major categories in mammalian cells being sphingosine, phytosphingosine and sphinganine. ${ }^{15}$ These core structures can be derivatized with an $\mathrm{N}$-acyl fatty acid chain (that can vary in length) to give ceramide (1), phytoceramide (2) and dihydroceramide (3), respectively.

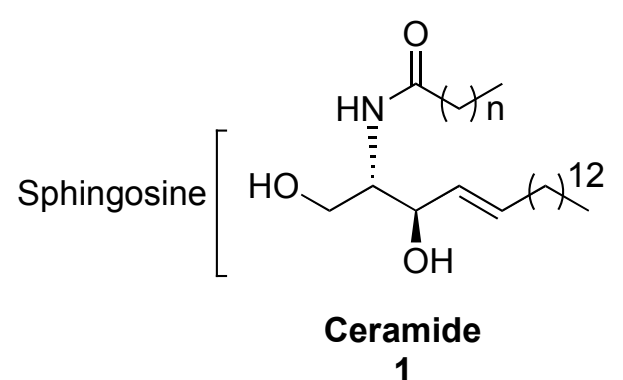

1

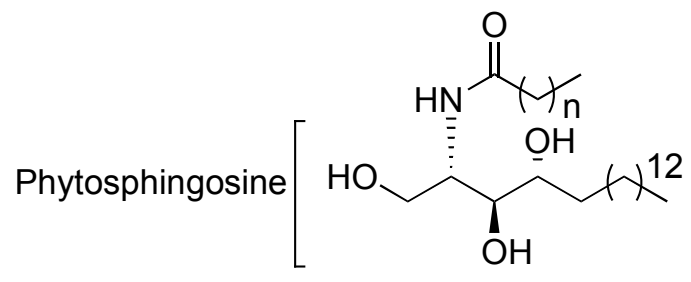

Phytoceramide

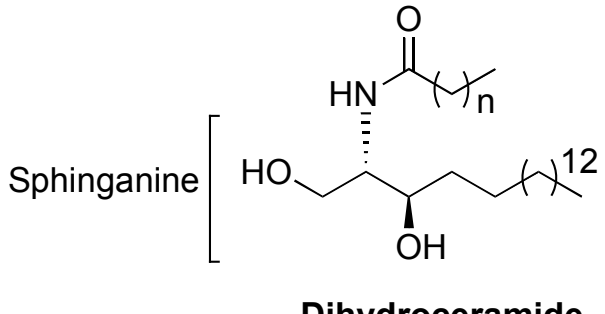

3

Figure 1.2. Three major categories of sphingoid base found in mammalian cells.

The six series of glycosphingolipids are composed of five more simple categories, di-gal, ganglio-, globo-, lacto- and neolacto-, and a sixth hybrid series (Figure 3). All contain a $\beta$-glycosidic linkage between the carbohydrate at the reducing end 
and the ceramide moiety. In all except the di-gal series, this sugar is a glucose residue. The ganglio-, globo-, lacto- and neolacto-series are further derivatized with a $1,4-\beta$-linked galactose residue. The ganglio-series contains a $1,4-\beta$-linked galactose residue, whereas the globo-series possess a 1,4- $\alpha$-linked galactose residue, and the lacto- and neolacto-series a 1,3- $\beta$-linked $N$-acetylglucoseamine sugar. The roles of GSLs on the cell surface can be roughly divided into two functions: 1) involvement in cell adhesion or recognition processes through interactions with other GSLs or lectins on neighbouring cells, and 2) influencing signal transduction through receptor proteins on the cell surface. ${ }^{16}$ GSLs are found at increased concentrations on the apical membranes of cells that line the inside of the stomach, intestines and respiratory tract. These membranes form a barrier between the body and the external world, and are the place of first contact for many pathogens. Consequently, bacteria, viruses and protozoans have evolved to exploit GSLs to aid in virluence. ${ }^{16}$ For example, the exotoxins excreted by Vibrio cholerae are known to bind to ganglioside GM1, and botulism toxin binds to gangliosides GD1b and GT1b. ${ }^{14}$ In addition, some bacteria have GSL-binding lectins that may mediate infectivity. GSLs can regulate gene expression via two proposed mechanisms: lipid-lipid interactions, where the bioactive GSL alters membrane structure and/or the interactions of membrane proteins with the membrane bilayer; or lipid-protein interactions, where changes in GSLs modulate the functions of proteins. ${ }^{17}$ Some GSLs mediate signal transduction through the formation of 'glycosynapses'. These are GSL rich, cholesterol independent membrane micro domains that contain tetraspanin, growth factor receptor, and cytoplasmic protein kinases. ${ }^{14}$ Another key function of GSLs is their involvement in immune responses. Notably, the GSLs $\alpha$-galactosylceramide ( $\alpha$-GalCer) and isoglobotrihexosylceramide (iGb3) are presented by the CD1d molecule to invariant natural killer $\mathrm{T}$ (iNKT) cells. This process and the cascade events that result, following $\mathrm{T}$ cell activation, are discussed in more detail in section 1.2. 


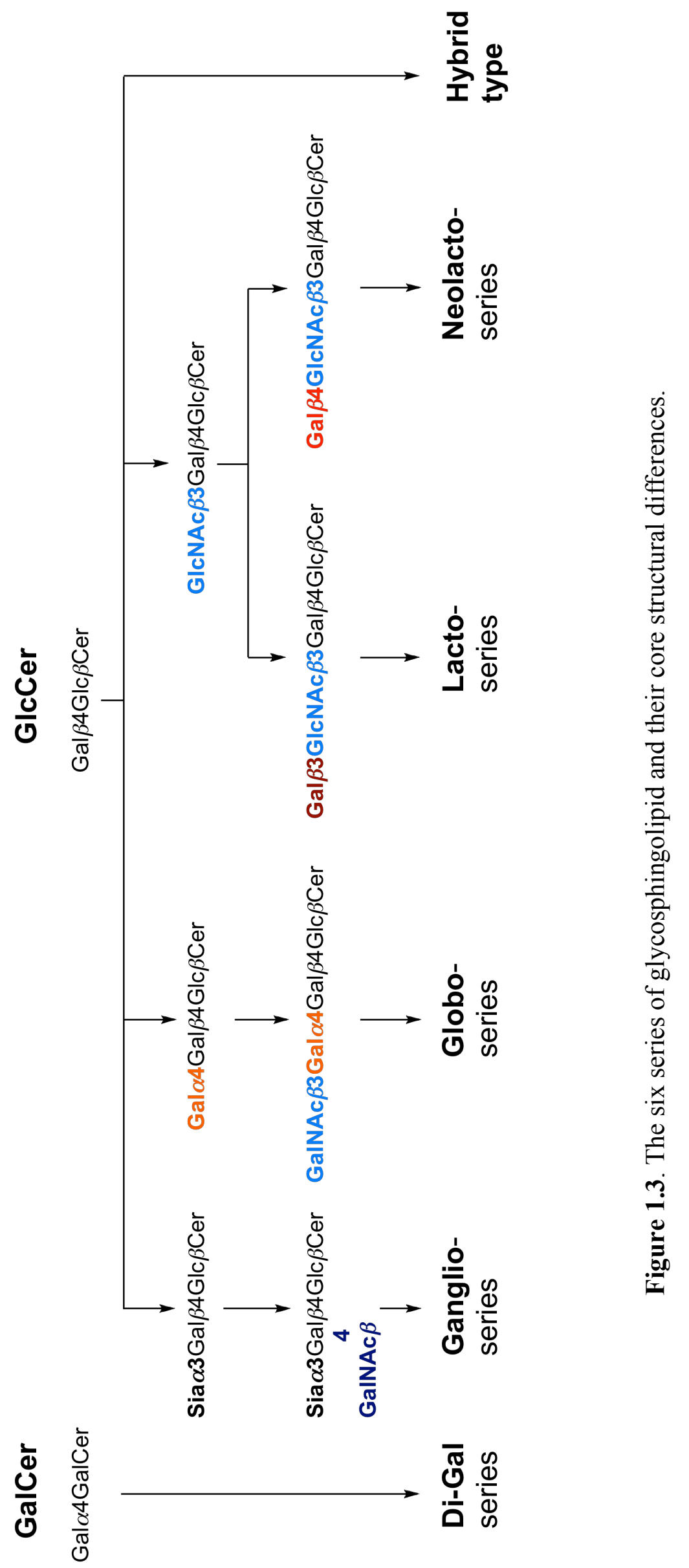




\section{Carbohydrate based drugs}

With the increase in the discovery of carbohydrate-related drug targets, the pharmaceutical potential of carbohydrates has been explored. ${ }^{18-20}$ One particularly important area of carbohydrate based drugs has been in the development of glycosidase inhibitors. ${ }^{5}$ Glycosidase enzymes catalyse the hydrolytic cleavage of carbohydrates. They have a vital role in a wide range of biological processes including intestinal digestion, the post translational modification of glycoproteins, lysosomal catabolism of glycoconjugates and in the mediation of some viral infections. ${ }^{21}$ If glycosidases do not function correctly, a number of diseases can result from the defective processing of carbohydrates. The inhibition of glycosidases can thus provide a valuable therapy for the treatment of diseases such as diabetes, cancer and influenza. ${ }^{21,22}$

Type II diabetes is caused by the body's inability to respond to insulin, which results in a reduced ability to store glucose as the glycogen polysaccharide. This, in turn, leads to increased blood sugar levels. ${ }^{23}$ Though there is no cure for diabetes, blood sugar levels can be controlled through the use of glycosidase inhibitors that prevent the breakdown of carbohydrate polysaccharides. ${ }^{24}$ Glycogen phosphorylase is responsible for the breakdown of glycogen into the glucose monomers and DAB (1,4-dideoxy-1,4-imino-D-arabinitol, 4, Figure 1.4), a potent inhibitor of glycogen phosphorylase, is currently being investigated for the treatment of type II diabetes. ${ }^{25}$ Another strategy for treating type II diabetes is via the regulation of carbohydrate absorption. This can be achieved by inhibiting intestinal glucosidase enzymes that break down dietary polysaccharides (e.g. starch) to smaller sugar units for absorption. Glyset, also known as miglitol (5, Figure 1.4), is one such anti-diabetic drug currently on the market. Miglitol inhibits $\alpha$-glucosidases from the pancreas and small intestine, ${ }^{18}$ preventing the hydrolysis of 1,4- $\alpha$-linked carbohydrates found in complex polysaccharides such as starch. 


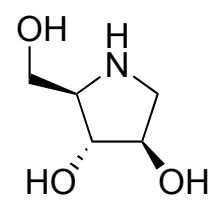

DAB (4)<smiles>OCCN1CC(O)C(O)[C@H](O)C1CO</smiles>

Miglitol (5)<smiles>OC1CCCN2C[C@H](O)[C@@H](O)[C@H]12</smiles>

Swainsonine (6)<smiles>OC[C@H]1N[C@H](c2c[nH]c3ccncc23)[C@H](O)[C@@H]1O</smiles>

DGJ (10)<smiles>O=c1[nH]cnc2c(CN3C[C@H](O)[C@@H](CO)C3)c[nH]c12</smiles>

DADMe-Immucillin-H (8)<smiles>C=N[C@@H]1OC(C(=O)O)=C[C@H](NC(=N)N)[C@@H]1C(O)CO</smiles>

Zanamivir (11)<smiles>CCCCN1CC(O)C(O)C(O)C1CO</smiles>

Miglustat (9)<smiles>C=N[C@H]1[C@@H](OC(CC)CC)C=C(C(=O)O)C[C@@H]1N(C)O</smiles>

Tamiflu (12)

Figure 1.4. Prominent glycosidase inhibitors.

Cancerous tumours express unusual complex carbohydrate structures resulting from abnormalities in the $N$-glycosylation pathway, and tumours that express greater numbers of aberrant glycosides are associated with poor clinical outcomes. ${ }^{26}$ The inhibition of key enzymes involved in $N$-glycosylation, such as Golgi $\alpha$-mannosidase II (dGMII), has shown potential in cancer treatment. ${ }^{27}$ In particular, swainsonine (6, Figure 1.4$)^{28}$ is a very effective inhibitor of murine cell invasion. Swainsonine acts by inhibiting Golgi $\alpha$-mannosidase II, blocking the expression of 1,6-branched complex-type $N$-linked oligosaccharides. These $N$ linked oligosaccharides are over expressed after malignant transformation and are required for effective tumour cell invasion. Swainsonine also enhances the natural anti-tumour defences of the body through stimulation of the immune system. ${ }^{29}$ 
Purine nucleoside phosphorylases (PNPs) are required by humans for the recycling of deoxyguanosine. $\mathrm{T}$ cell immune deficiency syndrome occurs as a result of a genetic deficiency of PNP, ${ }^{30}$ an observation that has made human PNP a target for the treatment of over activated $\mathrm{T}$ cells in disease such as $\mathrm{T}$ cell leukaemia and $\mathrm{T}$ cell related autoimmune disease. A number of synthetic high affinity transition state analogues have been developed as PNP inhibitors. Amongst the first generation inhibitors, Immucillin-H (7) and DADMeImmucillin-H (8, Figure 1.4) are the most notable with Pico-molar inhibition of PNP. These azasugar derivatives are currently in clinical trials for the treatment of leukemia. $^{31}$

Lysosomal storage disorders (LSDs) are a group of about 50 inherited metabolic disorders characterised by lysosomal dysfunction, and are usually a consequence of a single enzyme deficiency that is required for metabolism. Gaucher's disease, a type of LSD, results from deficient glucocerebrosidase activity leading to the accumulation of glucosylceramide in cells, particularly white blood cells, and in some organs including the spleen, liver, kidneys and brain. ${ }^{2}$ This can lead to problems such as liver malfunction, severe neurological complications and sclera (the growth of tissue over the eye). Enzyme replacement therapy can be used for some, but not all forms of the disease, and because of this, enzyme inhibitors, which reduce glucosylceramide levels, hold much promise as therapies for Gaucher's disease. Miglustat (9, Figure 1.4) is a glycosidase inhibitor that can be used to treat Gaucher's disease. ${ }^{18}$ Miglustat inhibits glucosylceramide synthase thereby resulting in a global reduction of GSL levels and reduced GSL accumulation (Figure 1.5). 

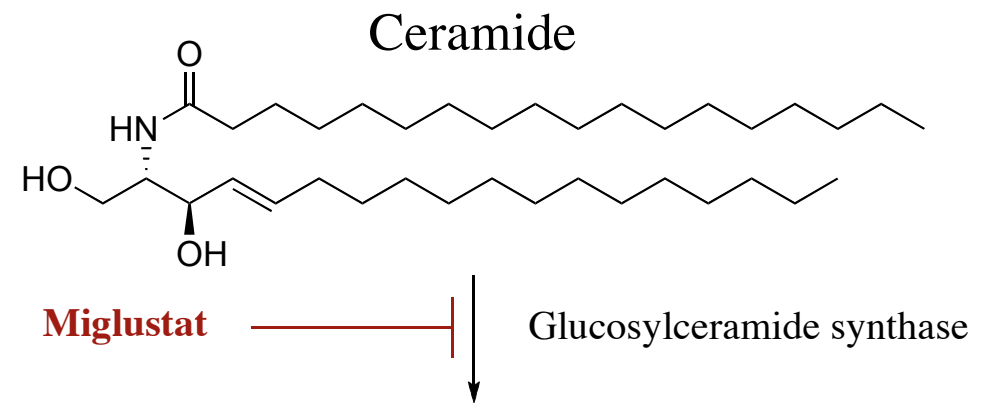

\section{Glucosylceramide}

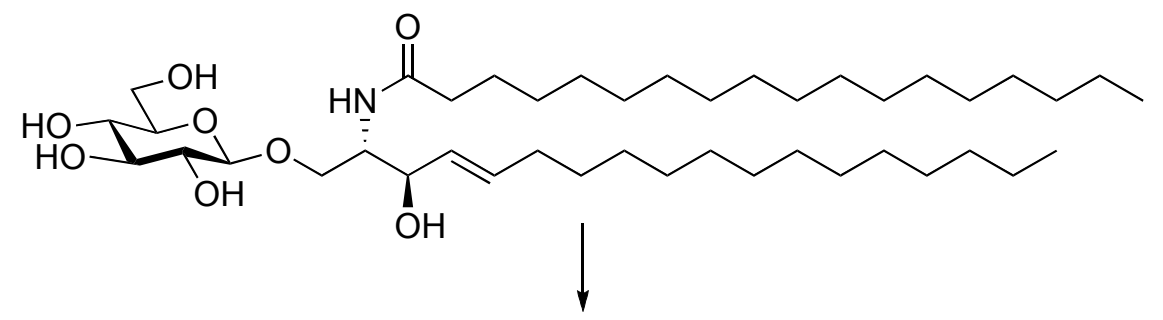

\section{Lactosylceramide}
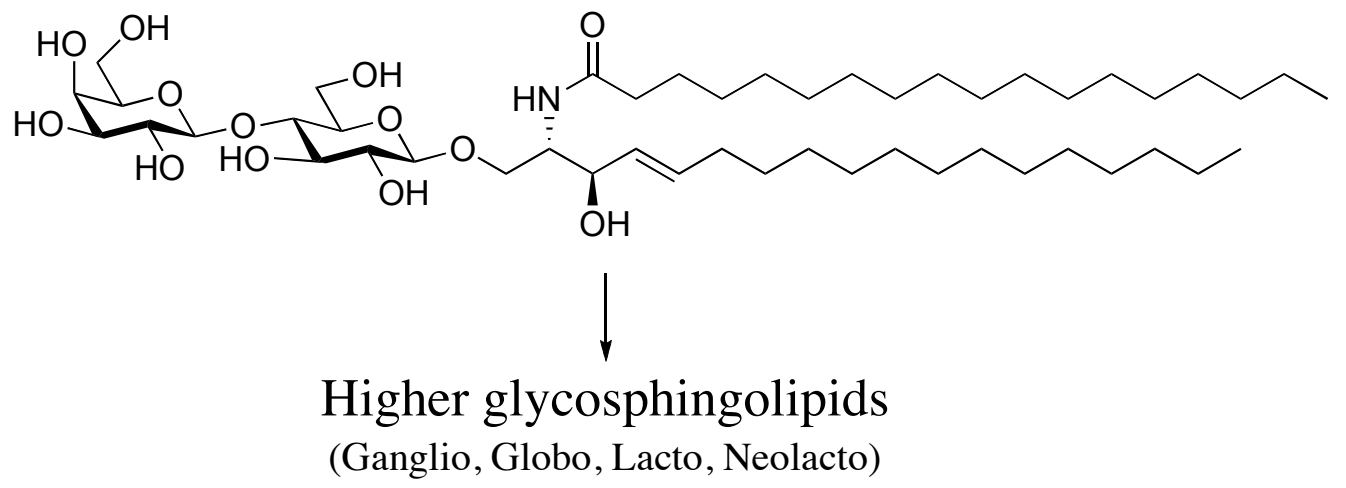

Figure 1.5. Inhibition of glucosylceramide synthase with Miglustat leads to a global reduction in glycosphingolipids via the reduced biosynthesis of glucosylceramide.

Fabry's disease, also a LSD, is caused by a deficiency in $\alpha$-galactosidase A. This enzyme hydrolyses the terminal galactose residue from $\mathrm{Gb}_{3} .{ }^{32} \mathrm{~A}$ deficiency in this enzyme leads to the accumulation of $\mathrm{Gb}_{3}$ and other related glycolipids within lysosomes. In the end stages of the disorder, renal disease and life-threatening cardiovascular or cerebrovascular complications limit life expectancy. 1Deoxygalactonojirymicin (DGJ, 10) is currently being investigated for its ability to treat Fabry's disease. ${ }^{32,33}$ Some forms of Fabry's disease are caused by misfolded enzymes. The firm binding between DGJ and the mutant $\alpha$-galactosidase A shifts the folding and stability of the enzyme in favour of the proper conformation and allows for a smooth escape of the enzyme from the ER for trafficking to the 
lysosomal compartment. Once in the lysosome $\alpha$-galactosidase A maintains its proper function. Though DGJ is an $\alpha$-galactosidase A inhibitor, remarkably, in the treatment of Fabry's disease leads to an increase in $\alpha$-galactosidase A levels within the cells of those with the mis-folded enzyme.

Another disease that can be treated by using a carbohydrate mimic is influenza. Influenza is an acute respiratory viral infection that affects millions of people each year. The influenza virus infects the respiratory epithelium by targeting sialic acid residues on glycoproteins and gangliosides. It uses two enzymes for this process: hemagglutinin, which enables the virus to attach to the host sialic acid and penetrate the plasma membrane; and neuraminidase, which enables the virus to detach itself after viral replication via sialic acid hydrolysis. ${ }^{5}$ Without neuraminidase, virus particles would not be able to escape the host cell surface and infect other cells. The inhibition of this enzyme therefore presents a valuable target for the treatment of influenza. Zanamivir (11, Figure 1.4) was the first neuraminidase inhibitor used for this purpose. Later in 2000 Tamiflu $^{\mathrm{TM}}(\mathbf{1 2})$ was developed. ${ }^{18,20}$ This neuraminidase inhibitor is more frequently used owing to its improved pharmacokinetic properties.

By and large, the majority of glycosidase inhibitors discovered to date are azasugars (carbohydrates where the ring oxygen is replaced with a nitrogen atom). In view of this, azasugars have become popular synthetic targets and are frequently screened for their ability to inhibit glycosidases. ${ }^{10}$ A more thorough analysis of the history and synthesis of azasugars will be discussed in section $\mathbf{1 . 3}$. 


\subsection{Glycolipid adjuvants for cancer immunotherapy}

Over the last decade, interest in cancer vaccination has increased as our knowledge and understanding of the immune system has developed. At the start of the $20^{\text {th }}$ century, cancer research focused predominantly on the development of new chemotherapeutic drugs, ${ }^{34}$ with some of the most successful drugs adding months to the lives of cancer patients. However, as most chemotherapeutics do not specifically target cancer cells, many have undesirable side effects. ${ }^{35-37}$ In light of this, therapeutic cancer vaccination strategies, in which the immune system is selectively activated to recognise and destroy tumour cells, are being developed to treat cancer. In 2010 the U.S. food and drug administration approved the first therapeutic cancer vaccine Provenge ${ }^{\circledR}$ for the treatment of prostate cancer. $^{38}$

Research into cancer vaccination began over 100 years ago with the work of William B. Coley. In 1892, Coley injected streptococcal bacteria into a patient with inoperable cancer to induce erysipelas (infection of the dermis) and stimulate the immune system. ${ }^{39,40}$ Coley observed that the malignant tumour reduced in size and he attributed this to the immune system destroying the cancer. Over the next 40 years, Coley continued to investigate this form of cancer therapy and treated hundreds of patients with inoperable bone and soft-tissue sarcomas. ${ }^{41}$ Coley's therapy used a heat-treated streptococcal bacterium combined with a second bacterium called Serratia marcescens. ${ }^{42}$ This concoction became known as Coley's Toxins and by the end of his career he had treated over 1,000 cancer patients. Although Coley's research generated widespread interest, it was criticised because his patient follow-up was poorly documented, 13 different toxin preparations were used, and his methods of administration were inconsistent. The growing popularity of radiation and chemotherapy coupled with the inability of others to reproduce his results, led to the demise of Coley's cancer immunotherapies and this avenue of research was largely ignored until the late 20th century. 


\section{Antigen presentation}

Our knowledge of the immune system and how an antigen is presented has grown considerably since Coley's time. Antigen presentation is a process by which antigen-presenting cells (APCs) enable T cells to recognise antigen. Antigens are presented by major histocompatibility complex (MHC) proteins on the surface of cells. $^{43}$ There are two types of MHC complexes: MHC I, which presents intracellular antigens, and MHC II, which is only displayed by specialised immune cells and presents antigens that have been phagocytosed. Each person has a unique set of MHC proteins that enables their own cells to be distinguished from another person's. Nucleated cells are constantly presenting peptide on their MHC I complexes. If the peptide is a self-peptide, no immune response will be generated. Alternatively, if the peptide is foreign, this antigenic peptide will be recognised by immature antigen presenting cells (APCs). There are two categories of APCs, professional and non-professional. Compared to non-professional APCs, professional APCs internalise and display antigen more efficiently. The dendritic cell (DC) is a type of professional APC, which plays an important role in cancer immunotherapy. ${ }^{44}$

During a primary immune response, immature DCs that have acquired antigen mature and migrate to the lymph node (Figure 1.6). Here they present the antigen on their MHC I receptors to the T cell receptor (TCR) on T cells. This interaction combined with cluster of differentiation (CD) 8 co-stimulation leads to $\mathrm{T}$ cell activation. ${ }^{45}$ Once the $\mathrm{T}$ cell is activated it divides and replicates, producing a number of $\mathrm{T}$ cells with the same TCR and the capacity to recognise the same specific antigen-MHC complex. These T cells migrate from the lymph node to the periphery seeking out cells that present the complementary antigen. The CD8+ T cells are then able to kill these foreign or defective cells (Figure 1.6). 


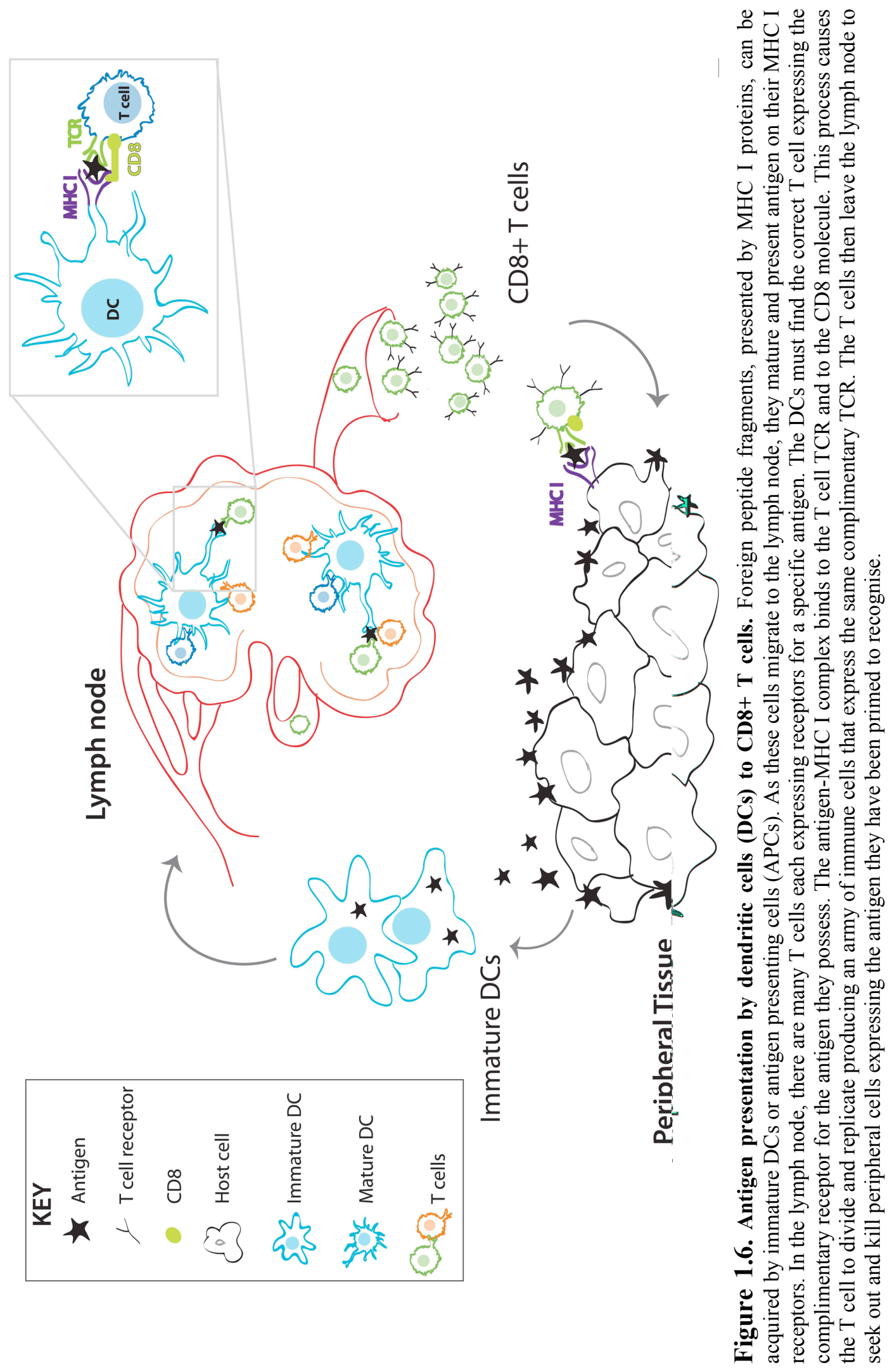




\section{Cancer immunotherapy}

The immune system can specifically identify and eliminate cancerous and/or precancerous cells on the basis of tumour-specific antigens induced by cellular stress. ${ }^{46}$ This process is called tumour immune surveillance. ${ }^{47}$ However, due to mechanisms not fully understood, a tumour cell is sometimes able to escape clearance. ${ }^{48}$ Once a tumour has developed, it is difficult for an immune response to be generated against it. ${ }^{49}$ There are two key reasons for this. First, tumour vasculature is incomplete and irregular making it difficult for immune cells to survey the tumour for antigen. Second, the tumour environment is highly immunosuppressive. This renders the majority of infiltrating immune cells inactive. The mechanisms contributing to the immunosuppressive microenvironment are not well understood, however a number of soluble suppressive factors such as TGF- $\beta$, VEGF, IL-10 and gangliosides have been implicated. ${ }^{49,50}$

Cancer immunotherapy aims to stimulate a patient's immune system and restore the defective elements of the antigen presentation pathway thereby enabling the immune system to attack the malignant tumour cells responsible for the disease. There are several types of immunotherapy regimes, which can be broadly grouped into non-specific and specific immunotherapy. In these strategies, tumour antigen is provided to activate the anti-tumour response and/or boost the immune response. Some of the cancer vaccination strategies under investigation include:

\section{Non-specific Immunotherapy:}

- Toll-like receptor (TLR) activation - TLRs recognise danger signals produced by microbes. ${ }^{51}$ This immunotherapy regime attempts to alarm immune cells by providing the danger signals usually produced by pathogens. $^{52}$

- Administration of cytokines - Cytokines can modulate anti-tumour responses. For example, interleukin (IL)-2 has been shown to offset defective antigen recognition and stimulate tumour destruction by $\mathrm{T}$ or Natural Killer (NK) cells. Cytokines have been used on their own, or in combination with other immunotherapy regimes. ${ }^{53-55}$ 
- NK cell therapy - In this therapy, NK cells are administered with IL-2 to induce tumour regression. The reduced level of MHC expression on tumours makes them especially susceptible to lysis by NK cells. ${ }^{56}$

\section{Specific Immunotherapy}

\section{ADOPTIVE TRANSFER.}

- Antibody adoptive transfer - Injection of prepared tumour-specific antibodies that can kill the tumour directly or activate anti-body dependent cellular cytotoxicity. For example, the anti-body bevacizumab targets vasculature endothelial growth factor (VEGF) promoting angiogenesis. ${ }^{57,58}$

- Adoptive cell transfer - Injection of cultured T cells pre-activated with tumour cells to target cancer antigens. ${ }^{59}$

\section{VACCINATION}

- Tumour cell vaccines - Vaccination with killed tumour cells mixed with a potent adjuvant. $^{60}$

- Tumour antigen vaccines - Administration of crude antigen mixtures (e.g. chaperone-peptide-rich complexes) extracted from tumours. ${ }^{60,61}$

- Peptide vaccines - Injection of defined peptide antigens (e.g. gp100) ${ }^{62}$ known to be expressed on tumours. These can bind to MHC I or II and be directly recognised by CD8 or CD4 T cells. ${ }^{63}$

- Dendritic cell (DC) vaccines - DCs are harvested from the blood of a cancer patient and primed ex vivo with killed tumour cells before reinjection into the patient. This enables the immune system to recognise the cancer as foreign (discussed in subsequent paragraphs). ${ }^{64}$

- Viral vectors and DNA vaccines - Delivery of naked DNA or viral vectors (e.g. adenovirus) encoding tumour antigen. ${ }^{60,65}$

- Idiotype vaccines - Delivery of an antibody that mimics a natural tumour antigen. These vaccines can stimulate the body to produce an immune response against tumour cells. ${ }^{60}$

Immunotherapy strategies are often combined to afford an improved treatment regime. For example, TLRs may be used in combination with DC vaccination. ${ }^{66}$ 


\section{DC based cancer immunotherapy}

The DC based cancer immunotherapy regime provides DCs with tumour antigen for presentation and initiation of the anti-tumour response (Figure 1.7). ${ }^{67}$ In this therapy, a portion of a patient's tumour is surgically removed. A blood sample is also taken from the patient and from this sample, immature DCs are isolated. Apoptosis is induced in the cancer cells ex vivo and the isolated DCs are primed using the dead cancer cells. This process loads the DC MHC I proteins with antigen from the tumour cells. Following maturation, the DCs are re-injected into the patient. The activated DCs prime the patient's immune response to target and kill cancer cells.

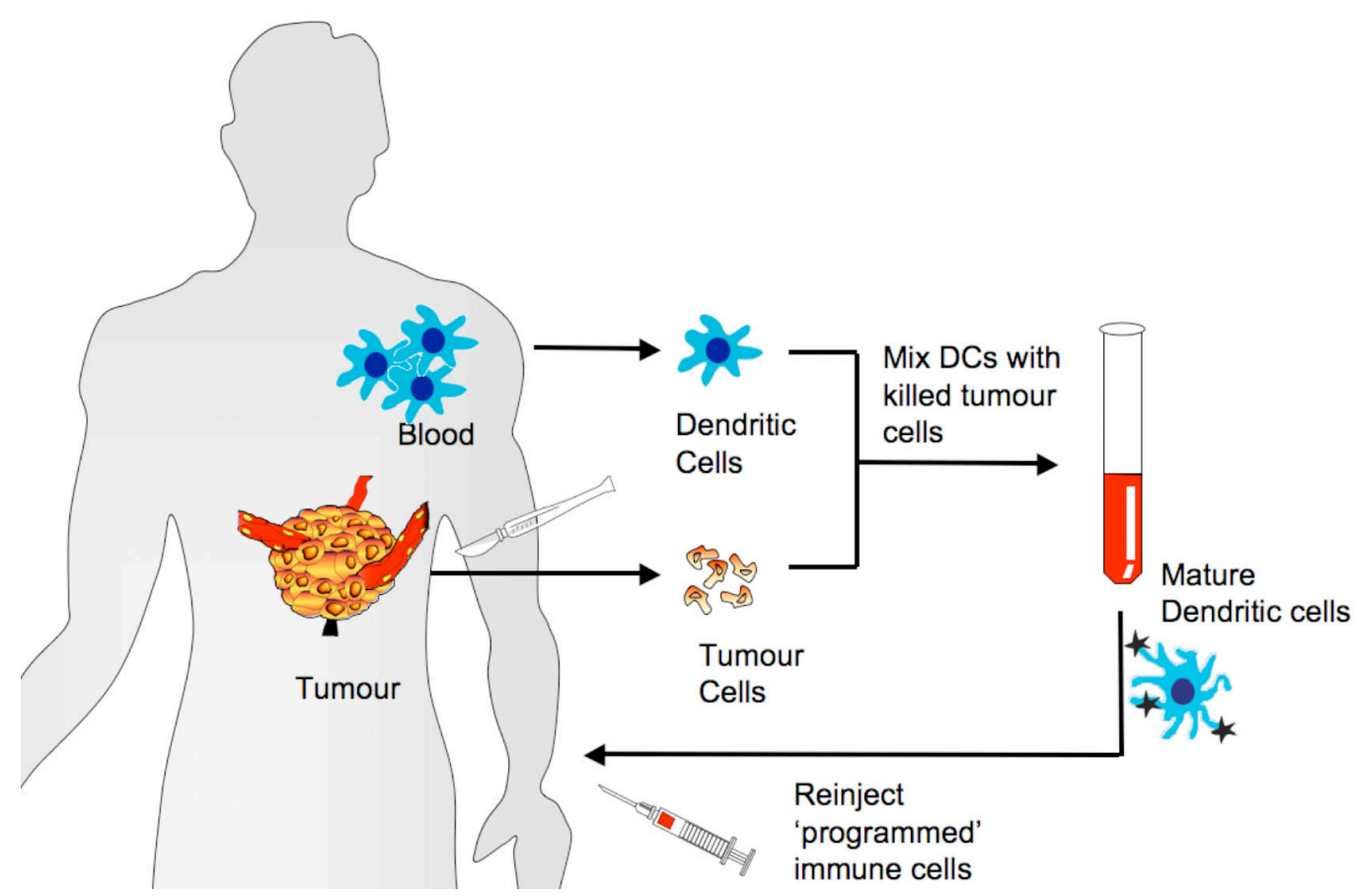

Figure 1.7. The DC cancer vaccination process. After surgical removal of tumour cells, the cells are killed and mixed with DCs from the patient's blood. These DCs then present the tumour antigen and, after maturation, are re-injected into the patient where they elicit an anti-tumour immune response.

Priming of the immune response occurs via MHC I presentation of antigen to $\mathrm{CD} 8+\mathrm{T}$ cells in the lymph node. This generates a cancer cell specific anti-tumour immune response because only those $\mathrm{CD} 8+\mathrm{T}$ cells with the correct receptor for binding to the specific cancer antigens (presented by the DC) are activated. Several cytokines, including IL-12 produced by the DCs, are also required for T cell activation. Once activated, the $\mathrm{CD} 8+\mathrm{T}$ cells migrate from the lymph node 
and travel around the body to find and destroy tumour cells presenting the specific peptide antigen. By activating the DCs ex vivo, the defective tumour vasculature and the immunosuppressive tumour environment are by-passed. This is because the apoptosed cancer cells are given directly to the DCs thereby improving the availability of the antigen. This ex vivo DC activation also enhances maturation and antigen presentation. Despite these benefits, the anti-tumour immune response generated is often too weak to reproducibly eliminate and prevent the reoccurrence of the cancer. By increasing the strength of the immune response, this therapy could be greatly improved. ${ }^{68}$ One way an immune response can be enhanced is via the activation of Natural Killer T (NKT) cells.

\section{NKT cells}

NKT cells are a distinct population of T lymphocytes with enormous therapeutic potential in the treatment of cancers and autoimmune disorders. They are powerful regulators of the immune system and their activation results in a cascade of events ultimately leading to an enhanced immune response. NKT cells constitute approximately 0.2 per cent of all peripheral blood T cells ${ }^{51,69}$ and share properties of both $\mathrm{T}$ cells and Natural Killer (NK) cells as they express both a semi-invariant $\mathrm{T}$ cell receptor (TCR) and NK cell markers. ${ }^{70}$ In contrast to the traditional T cell, the TCR of NKT cells recognises the carbohydrate portion of glycolipids presented by the 'MHC class I like' cluster of differentiation (CD)1d molecule. CD1d is a member of the CD 1 family of glycoproteins ${ }^{71}$ and is displayed on the surface of APCs including DCs, B cells and macrophages. ${ }^{72}$ The CD1d receptor has a hydrophobic region that binds to the lipid portion of a glycolipid antigen exposing the carbohydrate region to NKT cells. ${ }^{73} \alpha$ Galactosylceramide ( $\alpha$-GalCer, KRN7000, 13, Figure 1.8) is currently the most powerful glycolipid known to bind to CD1d and activate iNKT cells. This glycolipid is composed of a galactose head group and a ceramide lipid tail with a phytosphingosine base. The hydrophobic region of CD1d is composed of two binding pockets. The phytosphingosine chain of $\alpha$-GalCer binds to the F' pocket (alternatively termed the C' by Cerundolo and co-workers) ${ }^{73}$ and the longer acyl chain is anchored in the A' pocket. 


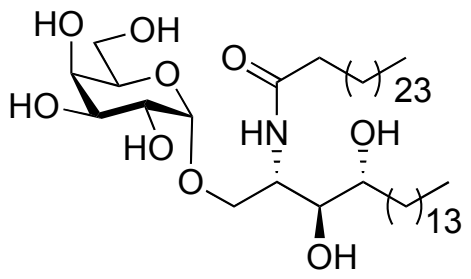

13, $\alpha$-GalCer

(KRN7000)

Figure 1.8. The well studied iNKT cell ligand $\alpha$-GalCer.

Although there are subtypes of CD1d-dependant NKT cells, the best characterised expresses a semi-invariant $\mathrm{T}$ cell receptor. These type 1 or semi-invariant NKT (iNKT) cells are conserved across the majority of the mammalian population and are found in both humans and mice. They express an invariant $\alpha$-chain combined with a limited, but not invariant, TCR $\beta$-chain. The TCR expressed by murine iNKT cells consists of an $\alpha$-chain encoded by a $V \alpha 14-J \alpha 18$ rearranged gene that is preferentially associated with a $\beta$-chain encoded by $V \beta 8.2, V \beta 2$, or $V \beta 7^{74}$ Human iNKT cells also express an invariant TCR, however, the $\alpha$-chain is encoded by the $V \alpha 24-J \alpha 18$ gene mainly associated with the $V \beta 11 \beta$-chain. Human and mouse iNKT cells are highly cross-reactive and mouse iNKT cells can recognise human CD1d as well as mouse CD1d, and human iNKT cells can also recognise both CD1d homologues. ${ }^{75}$ The unprecedented degree of conservation in this $\mathrm{T}$ cell recognition system suggests that it is fundamentally important. Furthermore, the highly conserved TCR of iNKT cells makes them an ideal target to activate for improved cancer immunotherapy regimes.

A number of glycolipids have been studied for their ability to bind to CD1d and activate iNKT cells. To date, $\alpha$-GalCer $(\mathbf{1 3}$, Figure 1.8$)$ is the most potent and well-studied iNKT cell ligand. Activation of iNKT cells by $\alpha$-GalCer leads to the immediate production of cytokines and an enhanced immune response. ${ }^{76}$ Upon activation, iNKT cells produce a host of cytokines such as interferon (IFN)- $\gamma$, IL4 , and to a lesser extent, IL-2 and tumour necrosis factor (TNF)- $\alpha$ (Figure 9). iNKT cell activation also leads to the trans activation of DCs and B cells which upregulate several maturation markers including CD80 and CD86 in response. ${ }^{77}$ CD80 (also called B7.1) and CD86 (B7.2) are co-stimulatory molecules that bind 
to CD28 on T cells enhancing the TCR mediated activation of T cells. ${ }^{78}$ Overall, this process leads to an enhanced CD8+ T cell anti-tumour immune response with each of the cytokines playing a different role. IFN- $\gamma$ and IL-4 both increase IL-12 production by DCs, and in turn, IL-12 increases the activity of CD8+ cells and stimulates NK cells. IL-2 stimulates the growth of CD8+ T cells and TNF- $\alpha$ is able to induce apoptosis and inflammation. 


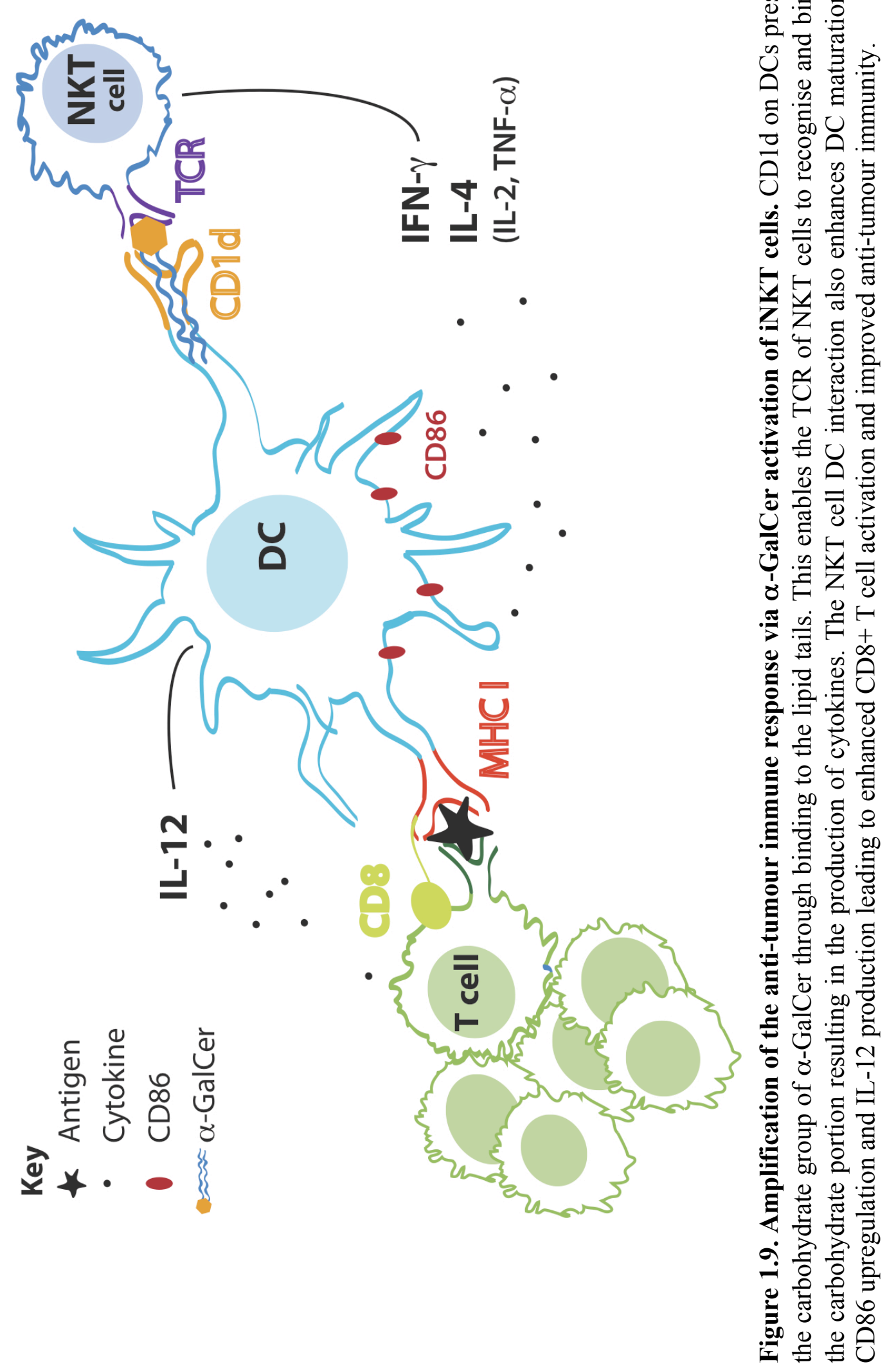




\section{Synthetic glycolipids for iNKT cell activation}

The discovery of $\alpha$-GalCer as a powerful CD1d binding lipid began in the 1990s when Kirin Pharmaceuticals isolated agelasphin-9b (14, Figure 1.10) from the marine sponge Agelas mauritianus. ${ }^{79,80}$ In 1995, a series of analogues were synthesised. ${ }^{81}$ These varied in fatty acid chain length, lipid chain length, and functional group substitution, with the goal being to identify a glycolipid that was easier to synthesise yet did not compromise on biological activity to any great extent. In murine studies it was discovered that 15 (Figure 1.10) was the most "desirable candidate for clinical application" ${ }^{81}$ due to its reduced structural complexity and improved tumour growth inhibition. Overall, it was found that longer ceramide lipid tail lengths improved activity, and the optimal lengths suggested in this study were C-18 for the lipid tail and C-24 or longer for the fatty acid chain. Several analogues were then tested for their ability to induce lymphocyte proliferation in human umbilical cord blood. ${ }^{81}$ When using human cells the activity of $\mathbf{1 5}$ was significantly reduced, and the importance of the 4hydroxyl on the lipid chain was discovered. This work eventually led to the selection of 13 (Figure 1.8) for future studies and in $1997 \alpha$-GalCer was identified as a potent iNKT cell ligand. ${ }^{82}$
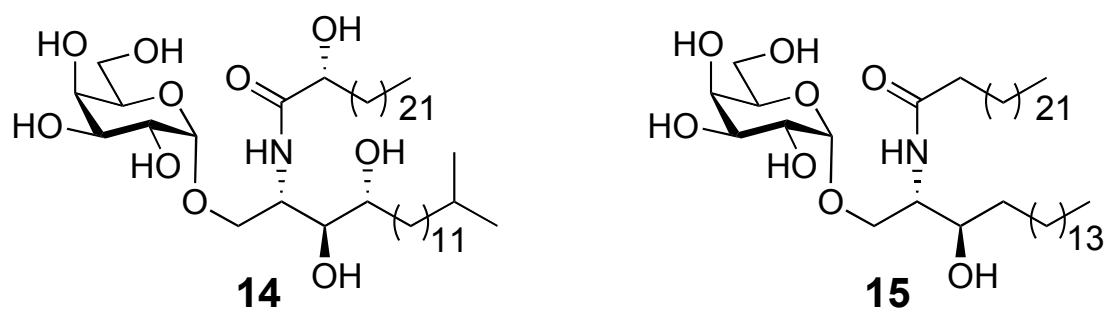

Figure 1.10. $\alpha$-Galactosylceramides isolated and synthesised in the development of the potent iNKT cell ligand KRN7000.

Several groups have synthesised structural analogues of $\alpha$-GalCer (13) to better understand which components are required for CD1d presentation and iNKT cell activation. The ceramide portion has been modified in a number of ways. These include the addition of aromatic residues, ${ }^{83,84}$ changes to lipid length, saturation and hydroxylation pattern ${ }^{85}$ and variations in the connectivity between the unfunctionalised lipid and the phytosphingosine backbone. ${ }^{86}$ Biological evaluation 
of these analogues has shown that the CD1d molecule is able to accommodate a variety of lipid tails, and that the structure of these can alter iNKT cell activation, probably through a combination of affinity (of the lipid for CD1d) and the angle of carbohydrate presentation to the iNKT cell. ${ }^{87-91}$

McCarthy et al. measured the rate at which $\alpha$-GalCer, and analogues thereof $(\mathbf{1 6}$, Figure 1.11), dissociated from CD1d. These $\alpha$-GalCer analogues varied in the length and saturation of the ceramide lipid. They found that the length of both lipid chains (phytosphingosine and acyl) affected the stability of the glycolipidCD1d complex. They then investigated the binding affinity of the TCR for the human CD1d glycolipid complexes. ${ }^{87}$ Here, they found a unique role for the phytosphingosine lipid chain (which occupies the CD1d F' channel) in modulating the TCR binding affinity to the hCD1d-lipid complex. Only alterations in the phytosphingosine length effected TCR affinity. It was concluded that incomplete occupation of the CD1d F' channel results in conformational changes at the TCR recognition surface, reducing the affinity of the iNKT cell TCR for the CD1d-glycolipid complex. These results demonstrate the importance of the $\alpha$-GalCer lipid lengths, and indicate that the C-26 acyl chain and the C-18 ceramide base are optimal lengths for potent iNKT cell binding and activation.

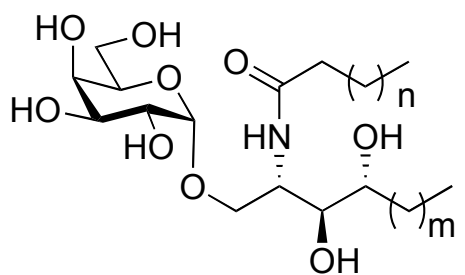

16

$$
\begin{aligned}
& \mathrm{n}=23: 0, \mathrm{~m}=13 \\
& \mathrm{n}=17: 0, \mathrm{~m}=13 \\
& \mathrm{n}=17: 2, \mathrm{~m}=13 \\
& \mathrm{n}=8: 1, \mathrm{~m}=13 \\
& \mathrm{n}=23: 0, \mathrm{~m}=7 \\
& \mathrm{n}=23: 0, \mathrm{~m}=4
\end{aligned}
$$

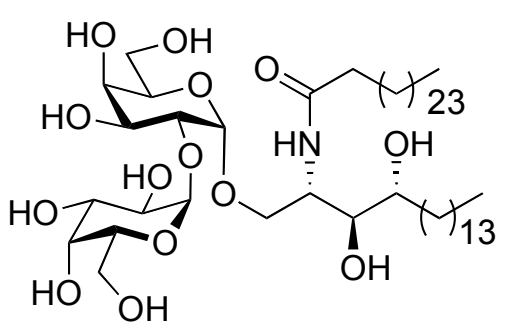

18

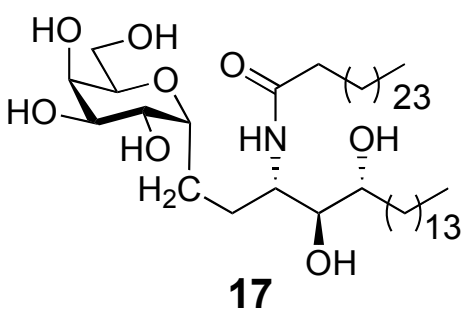

17

Figure 1.11. $\alpha$-GalCer analogues synthesised and tested for their ability to activate iNKT cells. 
Tsuji and co-workers discovered that the $C$-glycoside analogue of $\alpha$-GalCer $(\alpha-C$ GalCer, 17, Figure 1.11) was a more potent activator of mouse iNKT cells (than 13), as it stimulated prolonged cytokine production. ${ }^{88,89}$ Two explanations were proposed for this improved activity. First, the $C$-glycoside analogue may persist longer due to its intrinsic resistance to enzyme mediated hydrolytic degradation. Second, this unnatural mimetic may have altered receptor-binding properties. The activity of this analogue was then investigated toward human cells. However, it was found to be a less potent agonist for human iNKT cells. ${ }^{90}$ Tsuji and coworkers then investigated $E$-alkene linked glycolipids and found that some of these analogues were more potent activators of human, rather than murine, iNKT cells. $^{91}$

In addition to the synthesis of $\alpha$-GalCer analogues with structural modifications to the ceramide portion, some groups have synthesised analogues with additional carbohydrate residues attached to the galactose head group. For example, Besra and co-workers synthesised the galactosyl $(\alpha 1 \rightarrow 2)$ galactosyl ceramide derivative 18 (Figure 1.11). ${ }^{92}$ Interestingly, this analogue could only activate iNKT cells once it had been processed by APCs to $\alpha$-GalCer.

\section{Isoglobotrihexosylceramide (iGb3)}

Isoglobotrihexosylceramide (iGb3, 19, Figure 1.12) is the only other class of glycolipid known to bind to CD1d and activate iNKT cells. iGb3 mediated iNKT cell activation produces a similar cytokine profile to $\alpha$-GalCer, although at a reduced level. ${ }^{93}$ Its ability to bind to the TCR of iNKT cells demonstrates the unique ability of this TCR to recognise chemically diverse ligands presented by CD1d. ${ }^{94}$ iGb3 belongs to the family of glycolipids termed globosides, which are characterised as those having a sphingosine ceramide lipid tail attached via a $\beta$ linkage to a lactose disaccharide equipped with a 1,4- $\alpha$-linked galactose unit at the terminal position. This combination forms the most simple globoside core, termed Gb3 (Figure 3, pg 7). The most well-established role of globosides is to serve as cell surface antigens, such as blood group antigens ${ }^{95}$ or tumour associated antigens. ${ }^{17,96}$ Globosides also mediate cell adhesion and may be involved in signal transduction within cells. iGb3 differs from the standard globo-series in that the 
attachment of the terminal galactose is at the 3 " rather than the 4 " position of the lactose moiety. This seemingly minor change enables the activation of iNKT cells. Gb3, by contrast, is unable to induce cytokine production by iNKT cells. ${ }^{93}$ iGb3 is a lysosomal glycosphingolipid with previously unknown function. Accordingly, there has been considerable debate as to whether iGb3 is the ligand by which the invariant TCR of iNKT cells is selected upon. ${ }^{69,97}$ However, it seems unlikely that this glycolipid is critical to the development of iNKT cells as illustrated in studies where iNKT cell development was normal in mice deficient in the enzyme iGb3 synthase. ${ }^{98}$ In addition, it has been argued that humans do not have iGb3 because they lack any functional iGb3-synthase enzymes. ${ }^{99}$

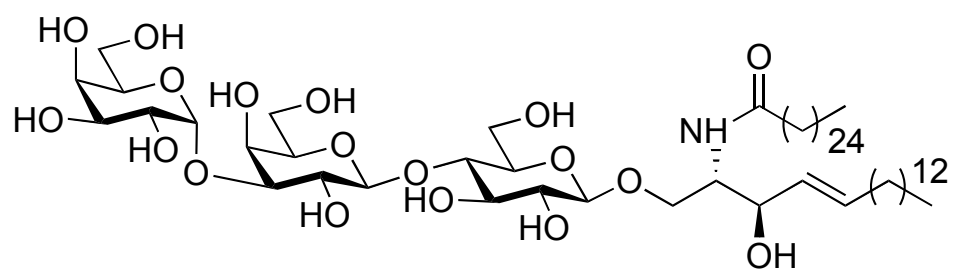

iGb3, 19

Figure 1.12. Isoglobotrihexosylceramide (iGb3)

A few iGb3 analogues have been synthesised and tested to gain insight into the critical elements required for iNKT cell activation, and to determine whether an enhanced response can be generated with this class of molecule. Chen et al. investigated a series of deoxy analogues in which the hydroxyl groups of the terminal galactose were systematically removed. ${ }^{100}$ The activities of the four iGb3 analogues were tested against murine iNKT cells and the level of IL-2 measured. This structure activity relationship study illustrated that the 2"' and 3"' hydroxyl groups appear to be critical for the recognition of iGb3 by iNKT cells. It was also suggested that modifications to the 4"' and 6"' positions of iGb3 should not diminish stimulatory activity. In 2009 Xia et al. synthesised the iGb3 analogues phytosphingosine 20 and sphinganine 21 (Figure 1.13) and investigated their ability to stimulate human iNKT cells. ${ }^{101}$ They discovered that the phytosphingosine analogue was 100 times more active than iGb3 itself (when tested using human iNKT cells). Savage and co-workers synthesised the $\alpha$ anomers of both iGb3 (22, Figure 1.13) and Gb3 (23). ${ }^{102}$ These glycolipids were 
effective iNKT cell antigens in both the human and murine settings and did not require lysosomal processing to the monoglycosylceramides for stimulation in mice.

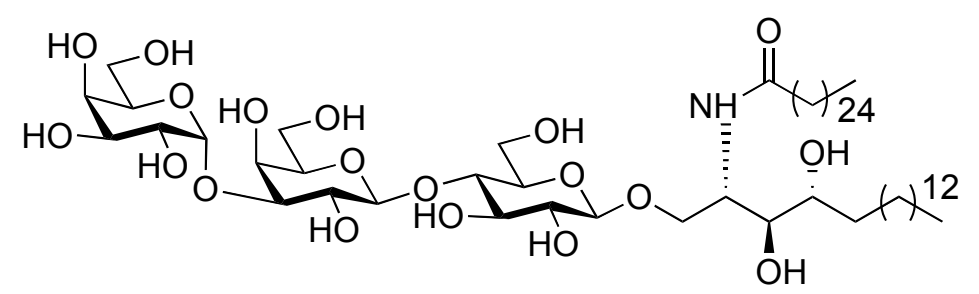

iGb3-phytosphingosine analogue, 20

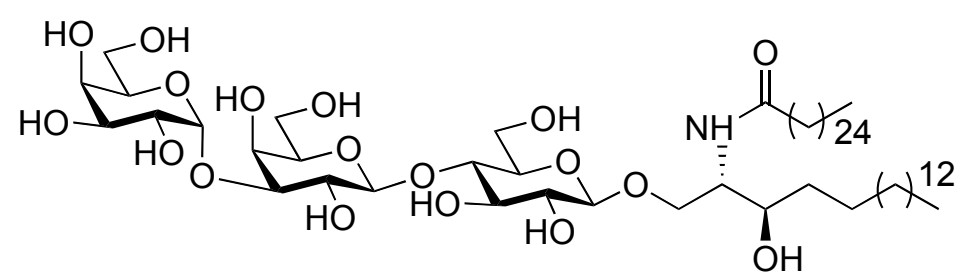

iGb3-sphinganine analogue, 21

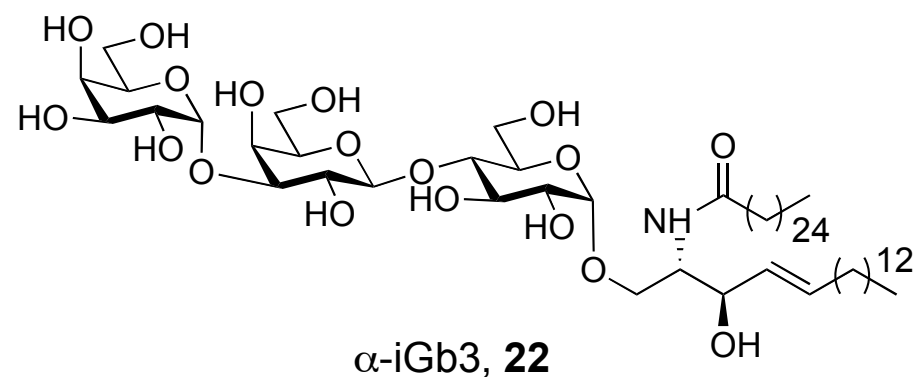

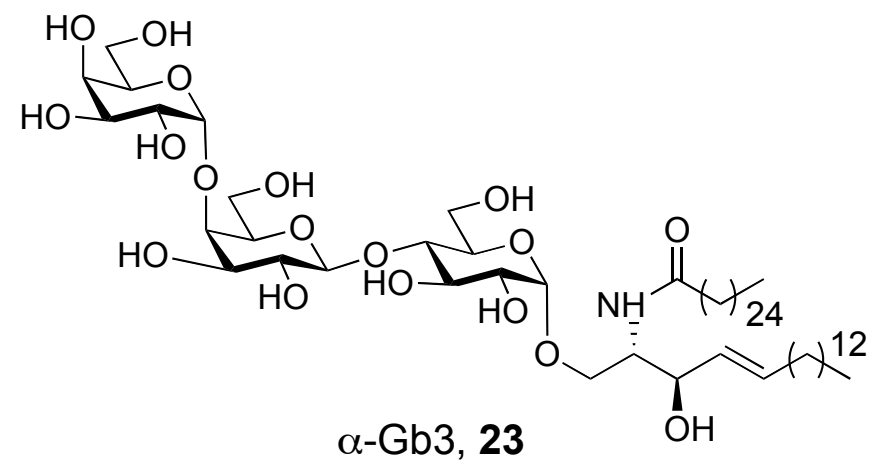

Figure 1.13. iGb3 analogues. 


\section{Species-specific activity of $\alpha$-GalCer analogues}

Despite the high degree of cross reactivity between human and mouse iNKT cells, there is accumulating evidence to suggest that glycolipid activity can be speciesspecific. In particular, the 4-hydroxyl on the ceramide lipid chain appears to be important for potent glycolipid activity in humans, but not in mice. As previously mentioned, sphinganine glycolipid 15 (Figure 1.10, pg 23) demonstrated potent activity in mice, however this did not correspond to human iNKT cell activity. ${ }^{81}$ In later studies, Kronenberg and co-workers investigated the activity of several glycosphingolipids, including $\alpha$-GalCer (13) and analogue 15, and observed that 13 was able to expand human iNKT cells from peripheral blood mononuclear cells (PBMCs), while sphinganine glycolipid 15 could not. ${ }^{103}$ They suggested this species-specific activity was due to differences in mouse and human CD1d structure. In the human system, studies by Xia et al. demonstrated that the phytosphingosine analogue of iGb3 (20, Figure 1.13) was 100 times more active than iGb3 itself (19, Figure 1.12) ${ }^{101}$ However, a recent article by Dubreuil and co-workers challenged this species-specific activity and suggested that $\mathbf{1 3}$ and $\mathbf{1 5}$ induced comparable human iNKT cell activation. ${ }^{104}$

Our interests lie in identifying the optimal iNKT cell glycolipid for use in cancer immunotherapy. Accordingly, the goal of this work is to identify the importance of the 4-hydroxyl on the lipid of $\alpha$-GalCer for activity in humans. Sphinganine $\mathbf{1 5}$ is a more attractive glycolipid adjuvant (cf. $\alpha$-GalCer (13)) in the clinical setting, because removal of the 4-hydroxyl reduces the complexity and length of the synthetic strategy. It has been suggested that the 4-hydroxyl is not important for glycolipid activity. ${ }^{104}$ In addition, we wish to compare the mouse and human models for investigating glycolipid activity. Mouse models are frequently used to determine the activity of a glycolipid in the context of iNKT cell activation. While these models are invaluable tools, and indeed, played a major role in the discovery of $\alpha$-GalCer, it is important to identify the limitations of these models. In the original work by Morita et al. the C-26 acyl chain was found to be the optimum length for potent activity, however, the sphinganine $\alpha$-GalCer analogue $\mathbf{1 5}$ synthesised only contained a C-24 acyl chain. ${ }^{81}$ Thus, to more fully understand the influence of the 4-hydroxyl on species-specific glycolipid activity, we want to 
synthesise $\alpha$-GalCer sphinganine analogue 24 (Figure 1.14), with the C-26 acyl chain, and investigate its activity in mice and humans. In addition, the $\alpha$-GalCer sphingosine analogue 25 (Figure 1.14) has not been synthesised and tested for activity. Sphingosine $\mathbf{2 5}$ provides an extra target to investigate the importance of the 4-hydroxyl for human iNKT cell activation. Together, studies investigating the activities of $\mathbf{2 4}$ and $\mathbf{2 5}$ will enable us to more fully understand the glycolipid structural elements required for potent iNKT cell activation in humans.

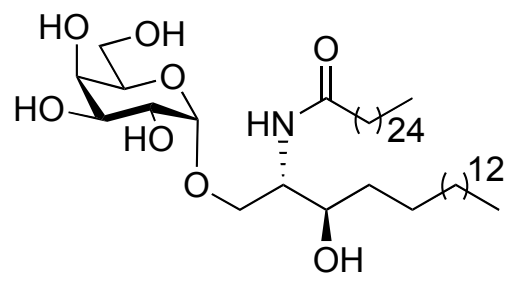

$\alpha-$ GalCer analogue with sphinganine lipid

24

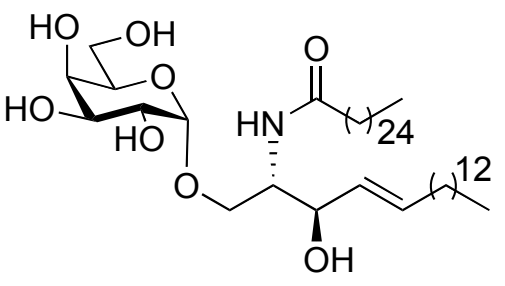

$\alpha-$ GalCer analogue with sphingosine lipid

Figure 1.14. Target $\alpha$-GalCer lipid analogues.

\section{Synthesis of $\alpha$-GalCer analogues}

A number of elegant strategies for the synthesis of $\alpha$-GalCer have been reported. ${ }^{81,104-110}$ We combined aspects of these strategies to develop an efficient route that allowed for the convergent synthesis of glycolipids 24 and 25 via a common late stage building block. For the synthesis of $\mathbf{2 4}$ and $\mathbf{2 5}$, we propose to use the donor developed by Wong and co-workers which contains a benzylidene acetal at the 4- and 6-hydroxyls and which leads to $\alpha$-selective coupling. ${ }^{105}$ As the lipid acceptor a sphingosine azide was chosen. While it is possible to couple the complete ceramide lipid, amides reduce the nucleophilicity of the primary hydroxyl and reduce the yield of the glycosylation reaction. ${ }^{107}$ The lipid acceptor will be synthesised by modifying the strategy developed by Schmidt and coworkers, ${ }^{111}$ whereby the hydroxy aldehyde used in the key Wittig metathesis will be prepared using a more efficient strategy, as reported by David et al. ${ }^{112}$ Alternative deprotection strategies will then be employed to synthesise $\mathbf{2 4}$ and $\mathbf{2 5}$ from a common late stage precursor. 


\subsection{The history and synthesis of azasugars}

Azasugars are structural analogues of traditional carbohydrates, where the ring oxygen is replaced with a nitrogen atom. Since the discovery of nojirimycin in $1966,{ }^{113}$ these sugar mimics have attracted considerable attention due to their ability to specifically and effectively inhibit carbohydrate-processing enzymes. Azasugars are found as secondary metabolites in a wide variety of plants and microorganisms and can be divided into the five classes: pyrrolidines, piperidines, indolizidines, pyrrolizidines and nortropanes (Figure 1.15). Pyrrolidines and piperidines are the most simple and are constructed of five or six membered rings, respectively. Indolizidines and pyrrolizidines are bicyclic structures that contain five - six (indolizidines) or five - five membered (pyrrolizidines) 1,2 fused rings. Nortropanes, also bicyclic structures, contain 2,6 fused five - six membered rings. Representative structures of each azasugar class are shown (Figure 1.15), however, as this thesis concerns the synthesis of piperidines and pyrrolidines, our attention will focus on these two classes of azasugars.<smiles>[R]C1NC(CO)C([O])C(O)C1[R]</smiles>

Piperidine
26, $\mathrm{R}=\mathrm{OH}, \mathrm{R}^{\prime}=\mathrm{OH}$ :

Nojirimycin

27, $\mathrm{R}=\mathrm{H}, \mathrm{R}^{\prime}=\mathrm{OH}$ :

Deoxynojirimycin (DNJ)

28, $\mathrm{R}=\mathrm{H}, \mathrm{R}^{\prime}=\mathrm{H}$ : Fagomine<smiles>O[C@H]1CN2CCC[C@H](O)[C@@]2(O)[C@@H]1O</smiles>

Indolizidine

Swainsonine<smiles>OCC1[C@@H](O)C(O)[C@@H]2[C@@H](O)CCN12</smiles>

Pyrrolizidine

Alexine<smiles>OC[C@H]1N[C@H](CO)[C@@H](O)[C@H]1O</smiles>

Pyrrolidine

\section{9}

2,5-Dihydroxymethyl3,4-dihydroxypyrrolidine (DMDP)

Figure 1.15. Representative structures of the five azasugar classes.

Nojirimycin (26) was the first naturally occurring azasugar isolated. ${ }^{113,114}$ This six membered azasugar, or piperidine, was first extracted from Streptomyces roseochromogenes in 1966 and was found to possess anti-microbial activity. 
Later, nojirimycin was also isolated from Streptomyces nojiriensis (from where it acquired the name nojirimycin). ${ }^{114}$ In addition to anti-microbial activity, nojirimycin is a potent inhibitor of $\alpha$ - and $\beta$-glucosidases. Ten years after the discovery of nojirimycin, deoxynojirimycin (DNJ, 27), originally named moranoline, was isolated from Mulberry trees, ${ }^{115}$ though it had been previously synthesised in $1966^{116}$ and $1968^{114}$ prior to its isolation. Fagomine (28) was first isolated from buckwheat seeds in 1974 (Fagopyrum esculentum Moench) ${ }^{117}$ and was first synthesised by Fleet et al. in $1985 .{ }^{118}$ Fagomine, a 1,2-dideoxy azasugar, is an inhibitor of mammalian $\alpha$-glucosidase and $\beta$-galactosidase ${ }^{19,120}$ and was reported to have anti-hyperglycemic effects in diabetic mice. ${ }^{121}$ Due to the instability of azasugars with an anomeric hydroxyl (e.g. 26) there has been more interest in the activity of C-1 deoxy azasugars (e.g. 27 and 28). The five membered azasugars, or pyrrolidines, were first discovered in 1976 when 2,5dihydroxymethyl-3,4-dihydroxypyrrolidine (DMDP, 29) was isolated from the leaves of Derris elliptica. ${ }^{122}$ However, DMDP's ability to inhibit glycoprotein processing enzyme glucosidase I was not discovered until several years later. ${ }^{123}$

\section{Azasugars as enzyme inhibitors}

As eluded to in section 1.1, carbohydrate processing enzymes play an important role in a wide range of diseases ${ }^{22,124}$ including cancer, ${ }^{125}$ Gaucher's disease, ${ }^{126}$ viral and bacterial infection, and diabeties, ${ }^{21}$ and accordingly, the development of specific and selective glycosidase inhibitors has become the target of many synthetic chemists. Arguably, the most valuable property of azasugars is their ability to inhibit glycosidase enzymes and it is this property that has been exploited during the development of a number of azasugar drugs. Glycosidases catalyse the hydrolysis of glycosidic linkages, releasing smaller sugar units (Scheme 1.1). The transition state of this reaction involves a positively charged oxocarbenium ion. At physiological $\mathrm{pH}$, the nitrogen atom of the azasugar is protonated and this charged species resembles the oxocarbenium ion transitionstate formed during carbohydrate hydrolysis. 


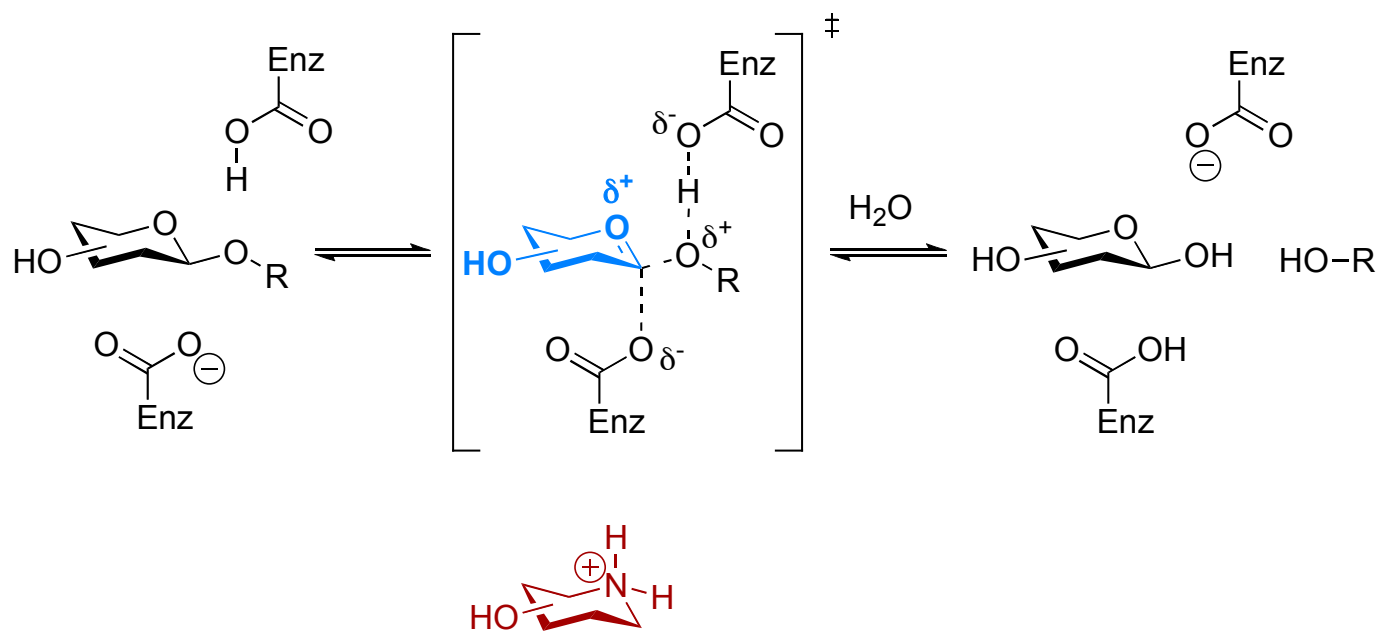

Scheme 1.1. General scheme illustrating the mechanism by which positively charged azasugars are able to mimic the glycosyl cation formed during carbohydrate hydrolysis.

In addition to their use as glycosidase inhibitors, azasugars have the potential to act as glycosyltransferase inhibitors. Glycosyltransferase enzymes catalyse the transfer of a monosaccharide donor to a glycosyl acceptor (Scheme 1.2) and are involved in the biosynthesis glycoconjugates such as of polysaccharides, glycoproteins and glycolipids. During the coupling reaction, a glycosyl cation transition state is formed. Once again, it is the positively charged ring nitrogen that is able to mimic the positively charged glycosyl cation formed during carbohydrate transfer.

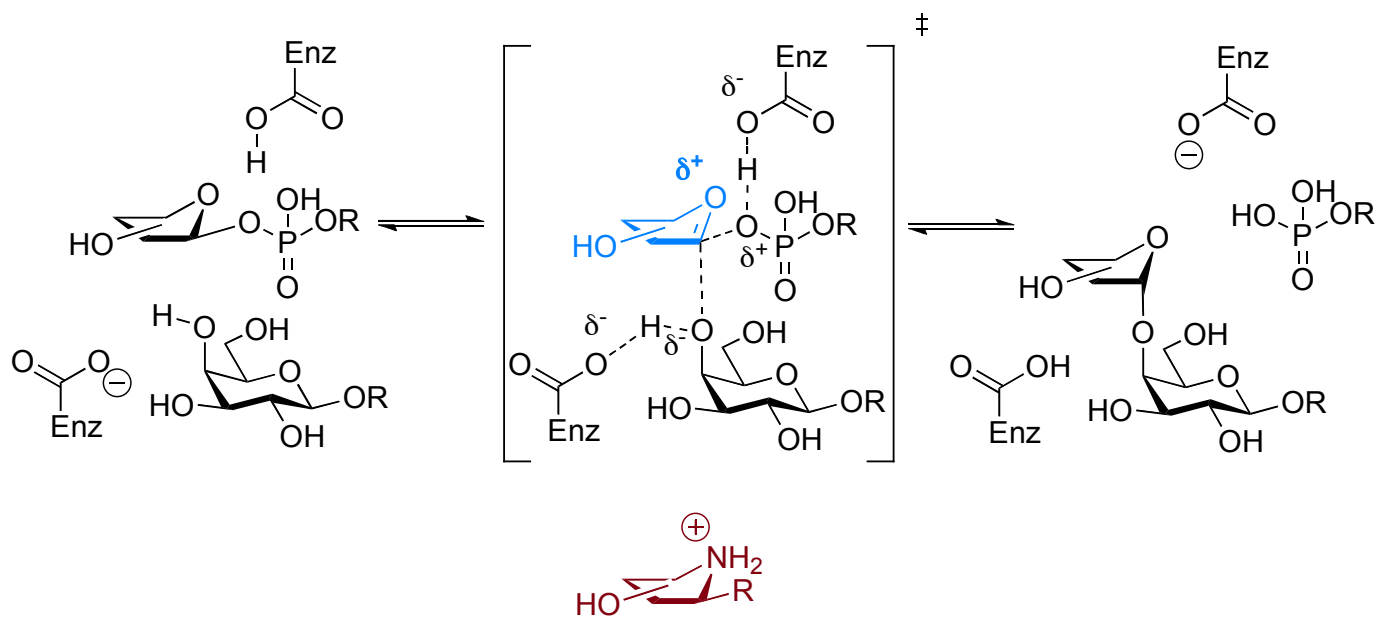

Scheme 1.2. Azasugar inhibition of glycosyltransferases.

Of particular interest to us is the potential use of azasugar mimics to treat tuberculosis (Tb). M. tuberculosis, the causative agent of Tb, has a thick outer cell wall that plays a critical role in the intrinsic resistance of mycobacteria to 
antibiotics, chemical injury and the immune response. ${ }^{127}$ One of the key features of this cell wall is that it contains large arabinogalactan (AG) polysaccharide components, which contains linear galactan chains and branched arabinose motifs. The arabinogalactan polysaccharide is constructed by arabinosyltransferase (AraT) enzymes that use arabinofuranosyl-1-monophosphoryldecaprenol (DPA) as the monomeric donor substrate. The AraT enzyme family catalyse the addition of the DPA donor to the growing arabinogalactan polysaccharide. During this coupling reaction, the donor carbohydrate goes through a positively charged glycosyl cation transition state (Scheme 1.2). Therefore, azasugars hold much promise for the treatment of $\mathrm{Tb}$.

Despite their valuable inhibitory properties, only a few azasugars have been widely studied for their therapeutic potential. This is largely due to the limited availability of many azasugars and the complexity of their synthesis. ${ }^{128}$ Methodology that enables azasugars to be synthesised in a fast and efficient manner is highly advantageous for full assessment of their inhibitory properties.

\section{Synthetic routes to five and six membered azasugars}

A number of routes have been developed for the synthesis of azasugars. These utilise a variety of key synthetic transformations including aldol and Wittig reactions, Michael additions, reductive aminations, substitution reactions, ringclosing metathesis, dihydroxylation, and pericyclic reactions. There are a number of excellent articles that review the total synthesis of azasugars. ${ }^{129-134}$ A few recent synthetic routes are summarised below.

In 2009, Poisson and co-workers developed an efficient non-chiral pool total synthesis of DNJ (27) in 11 steps with an overall yield of 24\% (Scheme 1.3). ${ }^{135}$ The key reactions in this synthesis were a one-pot ring closing metathesis and subsequent hydroboration. The route began with Sharpless asymmetric epoxidation of alcohol 30, followed by sodium hydroxide promoted rearrangement to give epoxide 31. Reaction of $\mathbf{3 1}$ with benzoyl isocyanate, followed by base promoted cyclisation gave carbamate 32 in a 77\% yield. This material was converted to protected diol $\mathbf{3 3}$ through Boc protection, followed by 
carbamate cleavage and benzylidene protection. $N$-Alkylation of $\mathbf{3 3}$ with iodide 34 provided diene 35, ready for the one-pot Grubbs metathesis and hydroboration step. The two-step one-pot conversion of diene $\mathbf{3 5}$ into protected azasugar $\mathbf{3 6}$ occurred smoothly (70\% yield) and allowed for the final deprotection and total synthesis of DNJ (27). While this approach involves a number of steps, the overall yield is competitive with the sequence being the most efficient of the non-chiralpool approaches for the synthesis of DNJ.
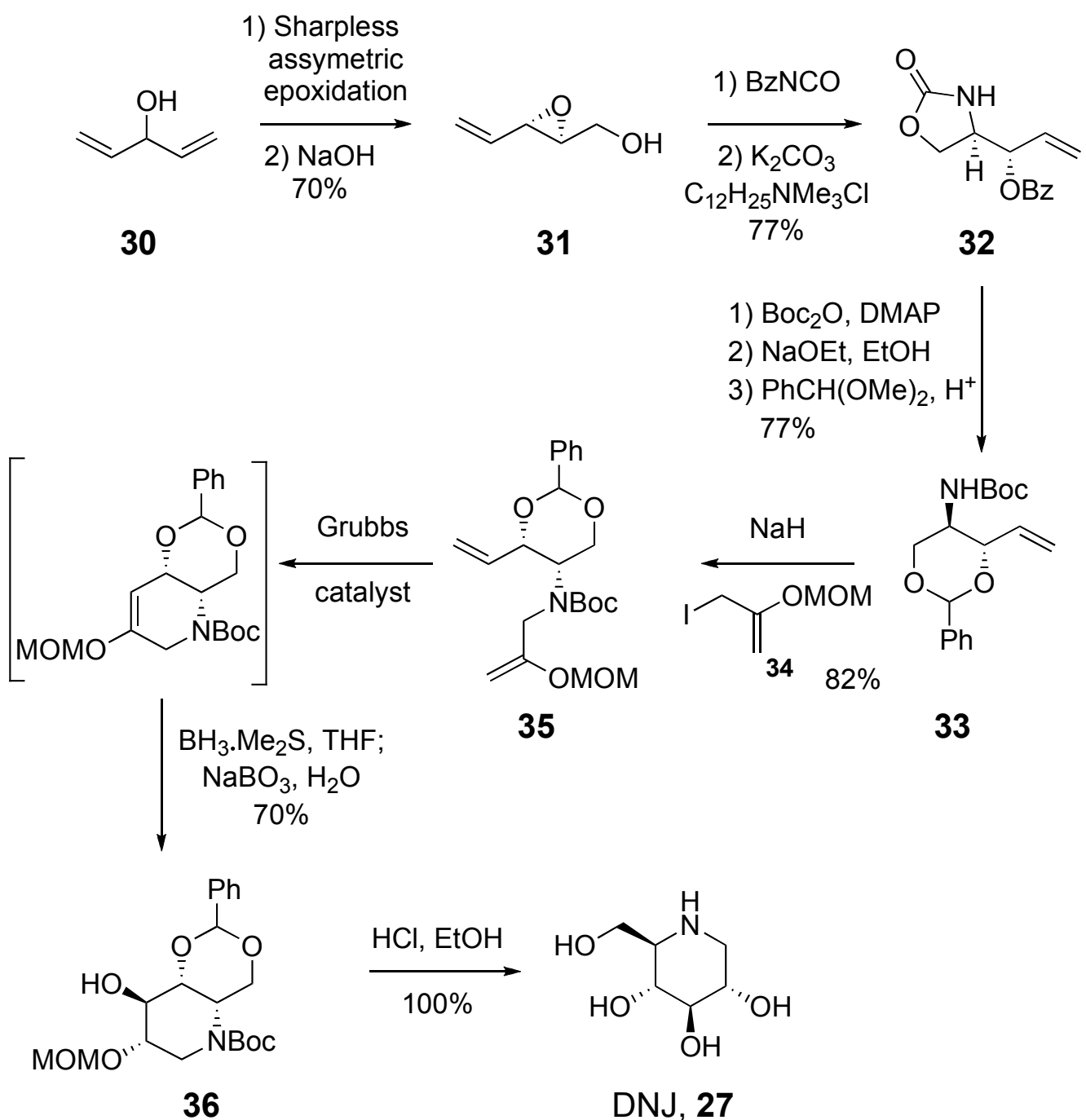

Scheme 1.3. Total synthesis of DNJ. ${ }^{135}$

In the same year Vankar and co-workers developed a route for the synthesis of six membered L-azasugars (Scheme 1.4). ${ }^{136}$ Their synthesis of L-allodeoxynojirimycin (43) was performed in 13 steps, with an overall 20\% yield. As the starting material, protected galactal $\mathbf{3 7}$ was used. Conversion of the primary hydroxyl to the trichloroacetimidate enabled the key 3,3-sigmatropic 
rearrangement to install the protected amine functionality at the anomeric position and gave amide 38. Reduction of amide $\mathbf{3 8}$ followed by Boc protection gave linear amine 39 in a $75 \%$ yield over the two steps. Next mesylation, followed by Boc deprotection enabled intramolecular $\mathrm{S}_{\mathrm{N}} 2$ cyclisation, induced by $\mathrm{K}_{2} \mathrm{CO}_{3}$, to give protected azasugar 40. Amine protection followed by osmium tetroxide dihydroxylation gave diol 41, which was cleaved using sodium periodate. The resulting ketone was reduced and the hydroxyl protected to give tribenzyloxy protected azasugar 42. Final deprotection with $\mathrm{H}_{2}$ on $\mathrm{Pd} / \mathrm{C}$ followed by acid mediated hydrolysis gave L-allo-deoxynojirimycin (43). The primary advantages of this synthesis are that it enables L-azasugars to be accessed from Dcarbohydrates. In addition, by varying the carbohydrate starting material, azasugars with different stereochemistries can be synthesised. Some of the disadvantages, however, include the use of osmium tetroxide, which is highly poisonous even at low exposure levels, and the requirement for complicated starting materials, which are difficult to obtain. 


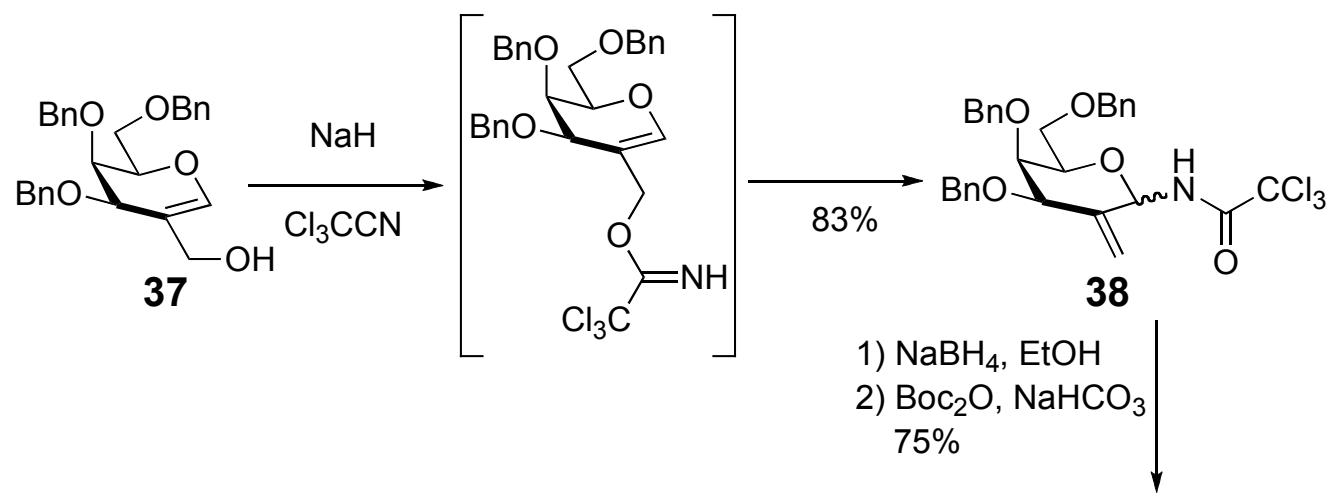

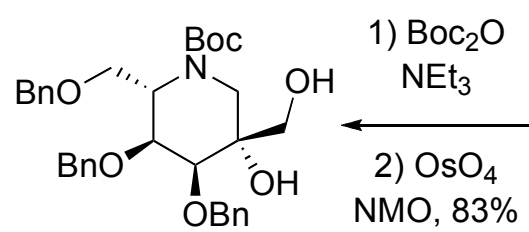

41

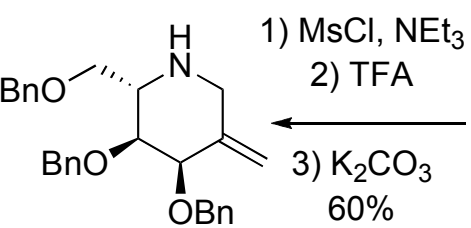

40<smiles>C=C1CC(O)C(OCc2ccccc2)C(O)C1CNC(=O)OCc1ccccc1</smiles>

39

1) $\mathrm{NaIO}_{4}, \mathrm{MeOH}$

2) $\mathrm{NaBH}_{4}, \mathrm{MeOH}$

3) $\mathrm{Ac}_{2} \mathrm{O}, \mathrm{NEt}_{3}$ $76 \%$<smiles>CC(=O)OC1CN(C(=O)OCc2ccccc2)[C@H](COc2ccccc2)[C@H](OCc2ccccc2)[C@H]1OCc1ccccc1</smiles>

42
1) $\mathrm{H}_{2}, \mathrm{Pd} / \mathrm{C}$

2) $6 \mathrm{~N} \mathrm{HCl}$, reflux $86 \%$<smiles>OC[C@H]1NC[C@@H](O)[C@H](O)[C@H]1O</smiles>

43

Scheme 1.4. Methodology for the synthesis of L-allo-deoxynojirimycin. ${ }^{136}$

In 2006, a synthesis of the rare five membered L-azasugar 1,4-dideoxy-1,4-iminoL-ribitol (49) was published (Scheme 1.5). ${ }^{137}$ This azasugar was synthesised in 9 steps from D-glucosamine, in an overall 21\% yield. D-Glucosamine 44 was subjected to diazotransfer followed by benzylidene protection to give azidoglucose 45 in a $75 \%$ yield. Next, anomeric protection and stereochemical inversion of the hydroxyl at the 3-position gave benzoyloxy-D-alloside 46. Benzyl protection of the 3-hydroxyl followed by reductive opening of the benzylidene protecting group gave azido-3,4-dibenzyloxy-D-alloside 47, which was converted to linear diol 48 via benzoyl deprotection and subsequent reduction using sodium borohydride in methanol. Target azasugar 49 was obtained through periodate cleavage followed by hydrogenation using palladium on charcoal. 

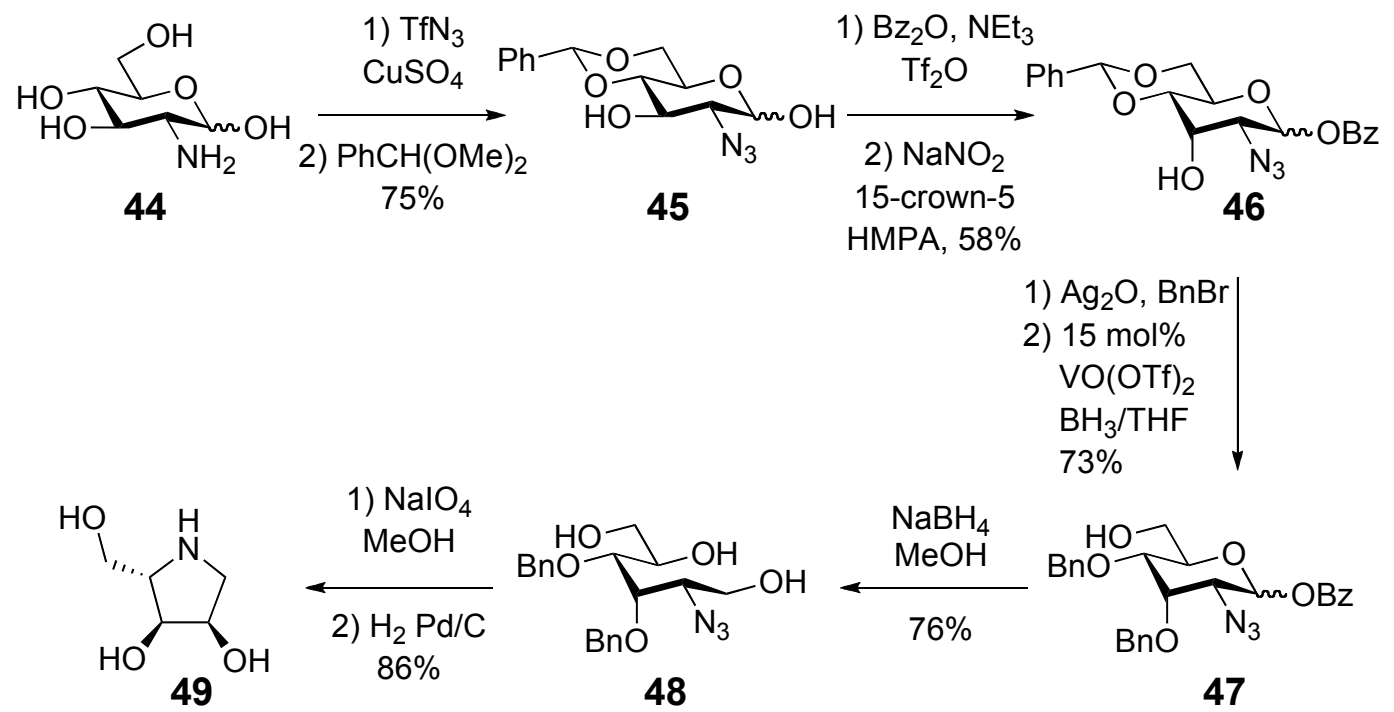

Scheme 1.5. Synthesis of 1,4-dideoxy-1,4-imino-L-ribitol. ${ }^{137}$

Fernández-Mayoralas and co-workers developed an elegant synthesis of five and six membered azasugars using a proline derived chiral catalyst to direct the stereochemistry of the key aldol reaction. ${ }^{138}$ In this work, (S)-proline was immobilised on a mesoporous silicate and the use of this catalyst in the aldol reaction of aldehyde $\mathbf{5 0}$ and ketone $\mathbf{5 1}$ resulted in anti-selective aldol product $\mathbf{5 2}$ (Scheme 1.6). Subsequent one-pot reduction/cyclisation of azide $\mathbf{5 2}$ led to the formation of five membered azasugar 53. Although the starting aldehyde is not commonly commercially available, it can be relatively easily synthesised from tartaric acid, and thus this route provides efficient methodology for the preparation of azasugars.

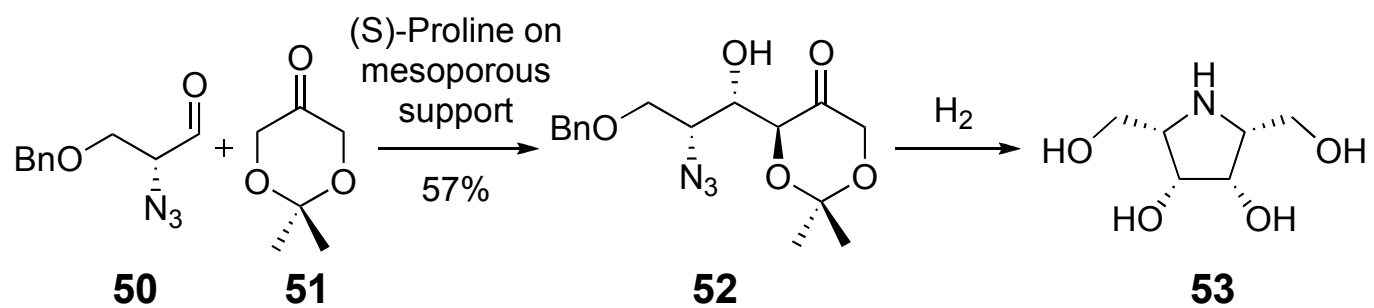

Scheme 1.6. Chiral catalysed aldol methodology for the synthesis of azasugars. ${ }^{138}$

An area of growing concern for the synthetic organic chemist is the ability to develop more efficient routes through reducing the number of protecting group manipulations used in a sequence. ${ }^{139}$ A protection/deprotection event introduces two additional steps, and incurs costs from additional reagents and waste disposal. 
With this in mind, Lindström et al. completed an efficient protecting group free synthesis of azasugar $\mathbf{5 7}$ in water. ${ }^{140}$ The synthesis commenced with a modified Sharpless asymmetric dihydroxylation of 1,6-dibromodiene 54. Hydrolysis of the allylic bromide gave diol 55, and subsequent stereoselective epoxidation using peroxotungstate catalyst $\mathrm{K}_{2}\left[\mathrm{~W}_{2} \mathrm{O}_{3}\left(\mathrm{O}_{2}\right)_{4}\left(\mathrm{H}_{2} \mathrm{O}\right)_{2}\right]$ gave 56 in a $97 \%$ yield over the two steps. Nucleophilic displacement of the bromide by ammonia led to spontaneous intramolecular ring-opening of the epoxide to afford azasugar $\mathbf{5 7}$ in an $88 \%$ yield. Overall, the total synthesis was performed in four steps in an impressive $60 \%$ total yield.
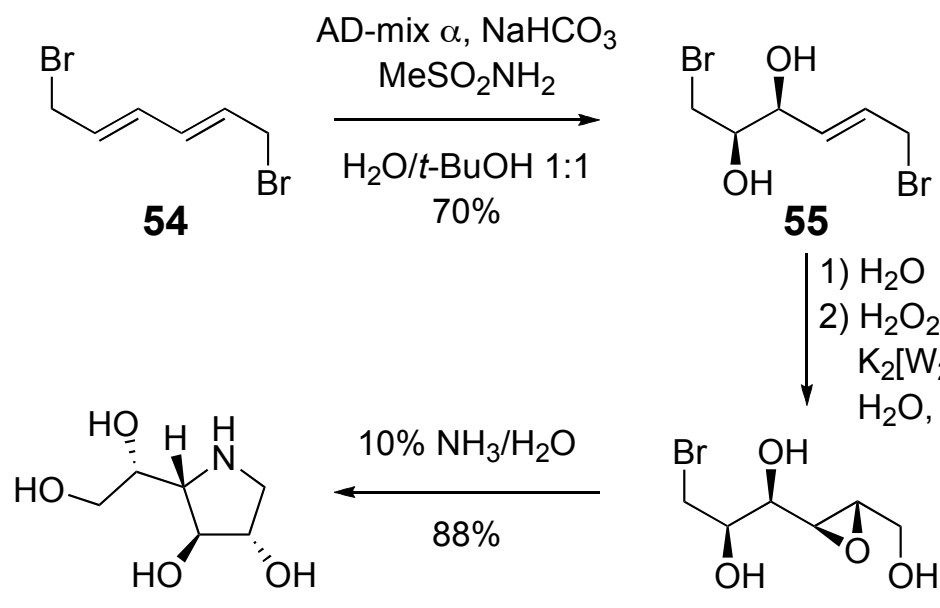

57<smiles>OCC1OC1C(O)C(O)CBr</smiles>

56

Scheme 1.7. The asymmetric synthesis of a five membered azasugar in water. ${ }^{140}$

\section{Proposed strategy for the protecting group free synthesis of azasugars}

By and large, the vast majority of strategies utilised for the synthesis of azasugars employ standard protecting group manipulations. The use of protecting groups has the disadvantage of requiring organic solvents for reaction, work-up and purification. ${ }^{139}$ In addition, extensive protecting group manipulations lead to lengthy syntheses requiring both protection and deprotection, resulting in reduced atom economy ${ }^{141}$ and hence reaction efficiency. In view of this, we investigated a protecting group free synthesis of azasugars to enable their efficient preparation and facilitate biological testing. 
In our protecting group free strategy, we proposed that azasugars $(\mathbf{5 8}$, Scheme 1.8) could be prepared via an iodine promoted carbamate annulation to give carbamates 59, which could be subsequently hydrolysed to give the desired azasugars. We postulated that the linear alkenylamines $(\mathbf{6 0})$ would be accessible via Vasella reductive amination of methyl iodofuranosides $\mathbf{6 1},{ }^{142,143}$ which can be prepared in two steps from the parent monosaccharides. ${ }^{144}$ To achieve this protecting group free strategy, two reactions were developed: the one pot iodine mediated carbamate annulation reaction and the Vasella reductive amination to form primary amines from aldehydes. We also hoped that the complete synthesis would be amenable to chemistry in aqueous media.<smiles>[R]C1CNC(CO)C1O</smiles>

58<smiles>[R][R](=CC=CC)C1C([R])=C(O)C2COC(=O)N21</smiles>

59

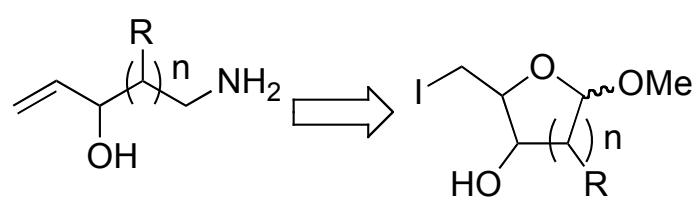

60

$$
\mathrm{R}=\mathrm{OH} \text { or } \mathrm{H}
$$

Scheme 1.8. Proposed retrosynthesis for the formation of five membered azasugars via cyclic carbamates.

In developing the one pot iodine promoted carbamate annulation reaction we wanted the cyclisation to be stereoselective. The use of electrophiles to promote nucleophilic addition to allylic alcohols has been well documented and when an internal nucleophile is used, the 'cis' product is formed preferentially (Scheme 1.9). ${ }^{145,146}$ Here the stereochemistry of the allylic alcohol directs the stereochemical outcome of the cyclisation. It was anticipated that similar stereo control could be extended en route to the desired carbamate. In addition to controlling the stereochemistry of the cyclisation, we also wanted to form the cyclic carbamate in situ.

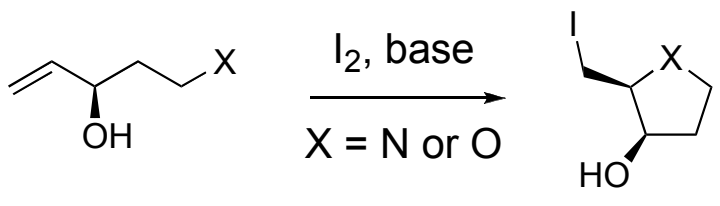

Scheme 1.9. Stereochemical outcome of iodine promoted cyclisations utilising an internal nucleophile. 
It has previously been reported that cyclic carbamates can be prepared, in modest yield, from the reaction of acyclic amines equipped with a halogen leaving group and either tetraethylammonium carbonate ${ }^{147}$ or sodium carbonate ${ }^{148}$ (Scheme $^{1}$ 1.10). In view of this, we postulated that carbamate building block 59 (Scheme 1.8) could be prepared via an iodine promoted cyclisation/in situ carbonylation using $\mathrm{NaHCO}_{3}$ as both the base, for the halocyclisation, and the source of $\mathrm{CO}_{2}$ for the carbamate annulation reaction.
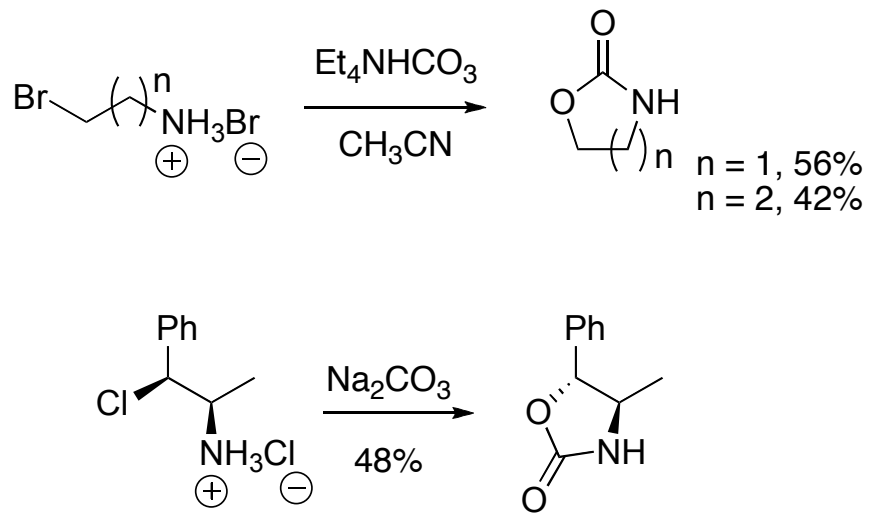

Scheme 1.10. Cyclic carbamate formation from acyclic amines equipped with a halogen leaving group.

Key in our protecting group free strategy was also the ability to synthesise the unprotected linear alkenylamines (60, Scheme 1.8) from iodoglycosides (61) using a one-pot Vasella reductive amination with ammonia as the amine nucleophile. The Vasella reaction allows for the reductive fragmentation of haloglycosides with zinc yielding alkenals. ${ }^{149}$ In Vasella's original work activated zinc and acetic acid were added to a solution of methyl bromoglucoside $\mathbf{6 2}$ in ethanol and the solution was stirred at reflux to give aldehyde 63 (Scheme 1.11). Magnesium, $\mathrm{Zn} / \mathrm{Cu}$ and $\mathrm{Zn} / \mathrm{Ag}$ were also investigated, however, no product was observed using these reagents. The Vasella reaction proceeds via oxidative insertion of zinc into the carbon-bromide bond, this is followed by reductive elimination with the loss of methoxide to give the aldehyde product. This methodology is generally applicable to the synthesis of alkenals from both pyranose $^{150}$ and furanose ${ }^{151}$ precursors equipped with iodide, ${ }^{152,153}$ bromide $^{154}$ or chloride ${ }^{155}$ substituents. We proposed to use the Vasella reaction to convert the methyl iodoglycosides (61) into alkenal substrates prior to reductive amination. 


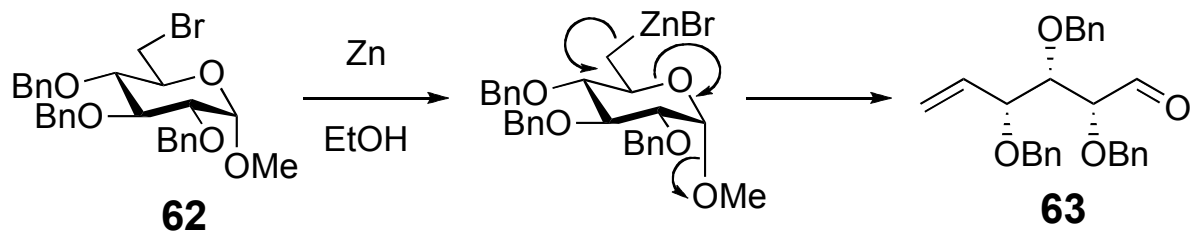

Scheme 1.11. Vasella reaction.

Traditionally, protecting groups have been used when preparing primary amines via metal hydride reductive amination, ${ }^{156-158}$ so as to prevent over alkylation. In the typical reductive amination a carbonyl, usually a ketone or an aldehyde (64), reacts with an amine (65) to form an imine (66) that is subsequently reduced (often with $\left.\mathrm{NaCNBH}_{3}\right)^{159}$ to give the desired amine product 67 (Scheme 1.12). However, when $\mathrm{R}^{2}=\mathrm{H}$, multiple alkylation events typically occur (68) resulting in the formation of the undesired secondary (69) or tertiary (70) amine products. ${ }^{160-162}$ This over-alkylation is a consequence of the increased reactivity of the primary amine product 67 (when $\mathrm{R}^{2}=\mathrm{H}$ ) compared to ammonia $\left(\mathbf{6 5}\right.$, when $\mathrm{R}^{2}$ $=\mathrm{H}){ }^{160,163,164}$ Though the formation of tertiary amines (70) can be reduced by increasing the number of amine equivalents and by adjusting the $\mathrm{pH}^{160}$ it is difficult to prevent the formation of secondary amines. To avoid this problem, primary or 'protected' amines $\left(\mathbf{6 5}, \mathrm{R}^{2}=\right.$ alkyl, aryl) are commonly used as the amine source. ${ }^{156-158}$

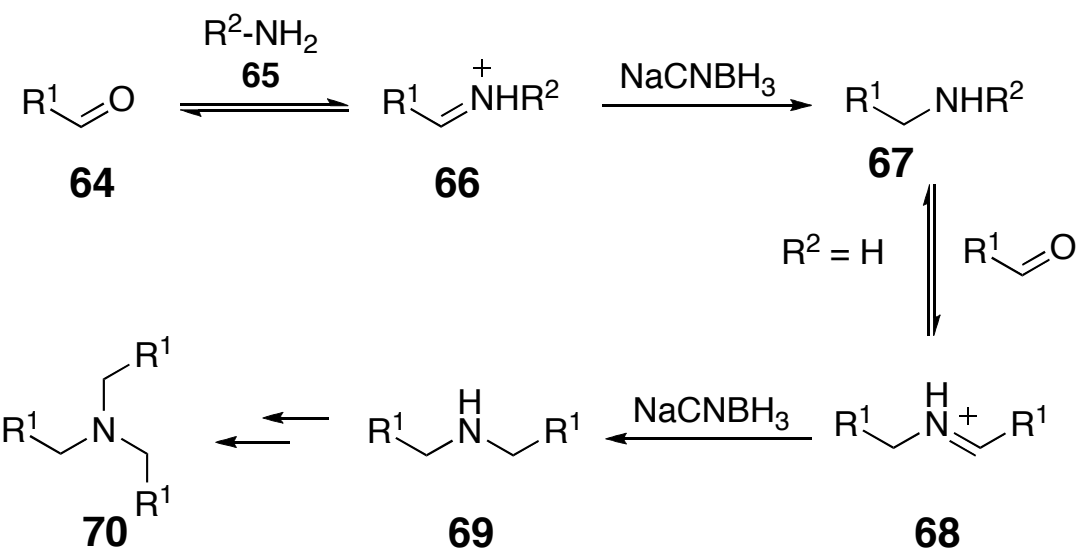

Scheme 1.12. Reductive amination of aldehydes.

Miriyala et al. recently developed alternative methodology for the synthesis of primary amines via selective reductive amination. Here, primary amines were 
produced from ketones using ammonia and titanium(IV) isopropoxide- $\mathrm{NaBH}_{4}{ }^{165}$ Unfortunately, the extension of this methodology to aldehydes was ineffective and predominantly resulted in secondary amine formation. This decreased selectivity is a consequence of the reduced steric bulk and high reactivity of aldehydes, making them even more likely to give over-alkylated products when compared to ketones. ${ }^{163}$ The selective metal hydride reductive amination of aldehydes to primary amines has, therefore, continued to be a significant challenge in scientific research. 


\subsection{Thesis outline}

The work in this thesis focuses on the synthesis of glycolipids and azasugars that could be used to treat disease. Chapters 2 and 3 describe the synthesis and biological evaluation of $\alpha$-GalCer lipid analogues to assess which lipid sphingoid base is required for potent iNKT cell activation in humans. In Chapter 4, methodology for the protecting groups free synthesis of azasugars is developed, and this work is expanded in Chapters 5 and 6. Chapter 5 focuses on further developing the reductive amination reaction using different iodoglycoside and aldehyde substrates, and Chapter 6 expands on the carbamate annulation methodology. In Chapter 7, the anti-tubercular activity of azasugars, and the azasugar building blocks is investigated. 


\subsection{References}

(1) Prescher, J. A.; Bertozzi, C. R. Nat. Chem. Biol. 2005, 1, 13-21.

(2) Gornik, O.; Dumić, J.; Flögel, M.; Lauc, G. Acta Pharm. 2006, 56, 19-30.

(3) Fischer, E. Ber. Dtsch. Chem. Ges. 1891, 24, 1836-1845.

(4) Fischer, E. Ber. Dtsch. Chem. Ges. 1891, 24, 2683-2687.

(5) The Organic Chemistry of Sugars; 1 ed.; Levy, D. E.; Fügedi, P., Eds.; CRC Press, 2006.

(6) Kunz, H. Angew. Chem. Int. Ed. 2002, 41, 4439-4451.

(7) Lichtenthaler, F. W. Angew. Chem. Int. Ed. 1992, 31, 1541-1696.

(8) Roseman, S. J. Biol. Chem. 2001, 276, 41527-41542.

(9) Cummings, R. D. Mol. BioSyst. 2009, 5, 1087-1104.

(10) Bertozzi, C. R.; Kiessling, L. L. Science 2001, 291, 2357-2364.

(11) Lindhorst, T. K. Essentials of Carbohydrate Chemistry and Biochemistry; 2 ed.; Wiley-Vch, 2003.

(12) Hosoi, E. J. Med. Invest. 2008, 55, 174-182.

(13) Comprehensive Glycoscience; 1 ed.; Kamerling, L. P.; Boons, G.-J.; Lee, Y. C.; Suzuki, A.; Taniguchi, N.; Voragen, A. G. J., Eds.; Elsevier, 2007; Vol. 3.

(14) Comprehensive Glycoscience; 1 ed.; Kamerling, L. P.; Boons, G.-J.; Lee, Y. C.; Suzuki, A.; Taniguchi, N.; Voragen, A. G. J., Eds.; Elsevier, 2007; Vol. 4.

(15) Pruett, S. T.; Bushnev, A.; Hagedorn, K.; Adiga, M.; Haynes, C. A.; Sullards, M. C.; Liotta, D. C.; Merrill Jr, A. H. J. Lipid Res. 2008, 49, 1621-1639.

(16) Wennekes, T.; van den Berg, R. J. B. H. N.; Boot, R. G.; van der Marel, G. A.; Overkleeft, H. S.; Aerts, J. M. F. G. Angew. Chem. Int. Ed. 2009, 48, 8848-8870.

(17) Patwardhan, G. A.; Liu, Y.-Y. Prog. Lipid Res. 2011, 50, 104-114.

(18) Brown, J. R.; Crawford, B. E.; Esko, J. D. Crit. Rev. Biochem. Mol. 2007, 42, 481-515.

(19) Meutermans, W.; Le, G. T.; Becker, B. ChemMedChem 2006, 1, 11641194.

(20) Ernst, B.; Magnani, J. L. Nat. Rev. Drug Disc. 2009, 8, 661-677.

(21) Asano, N.; Kato, A.; Watson, A. A. Mini Rev. Med. Chem. 2001, 1, $145-$ 154.

(22) Dwek, R. A.; Butters, T. D.; Platt, F. M.; Zitmann, N. Nature Rev. Drug Disc. 2002, 1, 65-75.

(23) Oikonomakos, N. G.; Tiraidis, C.; Leonidas, D. D.; Zographos, S. E.; Kirstiansen, M.; Jessen, C. U.; Nørskov-Lauritsen, L.; Agius, L. J. Med. Chem. 2006, 49, 5687-5701.

(24) Somsák, L.; Czifrák, K.; Tóth, M.; Bokor, E.; Chrysina, E. D.; Alexacou, K.-M.; Hayes, J. M.; Tiraidis, C.; Lazoura, E.; Leonidas, D. D.;

Zographos, S. E.; Oikonomakos, N. G. Curr. Med. Chem. 2008, 15, 2933 2983.

(25) Oikonomakos, N.; Tiraidis, C.; Leonidas, D. D.; Zographos, S. E.; Kristiansen, M.; Jessen, C. U.; Nørskov-Lauritsen, L.; Agius, L. J. Med. Chem. 2006, 49, 5687-5701.

(26) Dube, D. H.; Bertozzi, C. R. Nat. Rev. Drug Disc. 2005, 4, 477-488. 
(27) Wrodnigg, T. M.; Steiner, A. J.; Ueberbacher, B. J. Anticancer Agent. Me. 2008, $8,77-85$.

(28) Shaheen, P. E.; Stadler, W.; Elson, P.; Knox, J.; Winquist, E.; Bukowski, R. M. Invest. New Drug. 2005, 23, 577-581.

(29) Yagita, M.; Noda, I.; Maehara, M.; Fujieda, S.; Inouye, Y.; Hoshino, T.; Saksela, E. Int. J. Cancer 1992, 52, 664-672.

(30) Winchester, B. G. Tetrahedron: Asymmetry 2009, 20, 645-651.

(31) Balakrishnan, K.; Nimmanapalli, R.; Ravandi, F.; Keating, M. J.; Gandhi, V. Blood 2006, 108.

(32) Germain, D. P. Orphanet J. Rare Dis. 2010, 5:30.

(33) Fan, J.-Q.; Ishii, S.; Asano, N.; Suzuki, Y. Nature Med. 1999, 5, 112-115.

(34) DeVita Jr, V. T.; Chu, E. Cancer Res. 2008, 68, 8643-8653.

(35) Palmieri, F. M.; Frye, D. K.; Mahon, S. M. Clin. J. Oncol. Nurs. 2009, 13, 4-10.

(36) Ramirez, L. Y.; Huestis, S. E.; Yap, T. Y.; Zyzanski, S.; Drotar, D.; Kodish, E. Pediatr. Blood Cancer 2009, 52, 497-502.

(37) Menna, P.; Salvatorelli, E.; Minotti, G. Chem. Res. Toxicol. 2008, 21, $978-$ 989.

(38) April 29, 2010, Food and Drug administration Provenge (sipuleuel-T). Retrieved from www.fda.gov/BiologicsBloodVaccines/CellularGeneTherapyProducts/Ap provedProducts/ucm210012.htm 20 May, 2011

(39) Coley, W. B. Am. J. Med. Sci. 1893, 105, 487-511.

(40) McCarthy, E. F. Iowa Orthop. J. 2006, 26, 154-158.

(41) Coley, W. B. Proc. R. Soc. Med. 1910, 3, 1-48.

(42) Hoption Cann, S. A.; van Netten, J. P.; van Netten, C. Postgrad. Med. J. 2003, 79, 672-680.

(43) Germain, R. N. Cell 1994, 76, 287-99.

(44) Banchereau, J.; Briere, F.; Caux, C.; Davoust, J.; Lebecque, S.; Liu, Y.-J.; Pulendran, B.; Palucka, K. Annu. Rev. Immunol. 2000, 18, 767-811.

(45) Trombetta, E. S.; Mellman, I. Ann. Rev. Immunol. 2005, 23, 975-1028.

(46) Neller, M. A.; Lopez, J. A.; Schmidt, C. W. Semin. Immunol. 2008, 20, 286-295.

(47) Vesely, M. D.; Kershaw, M. H.; Schreiber, R. D.; Smyth, M. J. Ann. Rev. Immunol. 2011, 29, 235-271.

(48) Dunn, G. P.; Bruce, A. T.; Ikeda, H.; Old, L. J.; Schreiber, R. D. Nat. Immunol. 2002, 3, 991-998.

(49) Swann, J. B.; Smyth, M. J. J. Clin. Invest. 2007, 117, 1137-1146.

(50) Flavell, R. A.; Sanjabi, S.; Wrzesinski, S. H.; Licona-Limõn, P. Nat. Rev. Immunol. 2010, 10, 554-567.

(51) van Duin, D.; Medzhitov, R.; Shaw, A. C. Trends Immunol. 2006, 27, 4955 .

(52) Salaun, B.; Lebecque, S.; Matikainen, S.; Rimoldi, D.; Romero, P. Clin. Cancer Res. 2007, 13, 4565-4574.

(53) Okada, H.; Lieberman, F. S.; Walter, K. A.; Lunsford, L. D.; Kondziolka, D. S.; Bejjani, G. K.; Hamilton, R. L.; Torres-Trejo, A.; Kalinski, P.; Cai, Q.; Mabold, J. L.; Edington, H. D.; Butterfield, L. H.; Whiteside, T. L.; Potter, D. M.; Schold Jr, S. C.; Pollack, I. F. J. Transl. Med. 2007, 5:67. 
(54) He, H.; Wisner, P.; Yang, G.; Hu, H. M.; Haley, D.; Miller, W.; O'Hara, A.; Alvord, W. G.; Clegg, C. H.; Fox, B. A. J. Transl. Med. 2006, 4, $24-$ 40.

(55) Parmiani, G.; Rivoltini, L.; Andreola, G.; Carrabba, M. Immunol. Lett. 2000, 74, 41-44.

(56) Grzywacz, B.; Miller, J. S.; Verneris, M. R. Best Prac. Res. Cl. Ha. 2008, 21, 467-483.

(57) Kern, F.; Gratama, J.; Manca, F.; Roederer, M.; Willemsen, R.; Chames, P.; Schooten, E.; Gratama, J.; Debets, R. Cytometry 2008, 73A, 10931099.

(58) Aldrich, J. F.; Lowe, D. B.; Shearer, M. H.; Winn, R. E.; Jumper, C. A.; Kennedy, R. C. Clin. Dev. Immunol. 2010, 1-12.

(59) Stauss, H. J.; Cesco-Gaspere, M.; Thomas, S.; Hart, D. P.; Xue, S. A.; Holler, A.; Wright, G.; Perro, M.; Little, A. M.; Pospori, C.; King, J.; Morris, E. C. Mol. Ther. 2007, 15, 1744-1750.

(60) Briones, J. Clin. Transl. Oncol. 2008, 10, 543-551.

(61) Huang, C.; Zhao, J.; Li, Z.; Li, D.; Xia, D.; Wang, Q.; Jin, H. Cancer Epidemiol. 2010, 34, 494-500.

(62) Iero, M.; Filipazzi, P.; Castelli, C.; Belli, F.; Valdagni, R.; Parmiani, G.; Patuzzo, R.; Santinami, M.; Rivoltini, L. Cancer Immunol. Immunother. 2009, 58, 1159-1167.

(63) Dao, T.; Scheinberg, D. A. Best Prac. Res. Cl. Ha. 2008, 21, 391-404.

(64) Palucka, K.; Ueno, H.; Banchereau, J. J. Immunol. 2011, 186, 1325-1331.

(65) Lian, H.; Jin, N.; Li, X.; Mi, Z.; Zhang, J.; Sun, L.; Li, X.; Zheng, H.; Li, P. Cancer Immunol. Immunother. 2006, 56, 181-192.

(66) Hermans, I. F.; Silk, J. D.; Gileadi, U.; Masri, S. H.; Shepherd, D.; Farrand, K. J.; Salio, M.; Cerundolo, V. J. Immunol. 2007, 178, 27212729.

(67) Lesterhuis, W. J.; Aarntzen, E. H. J. G.; De Vries, I. J. M.; Schuurhuis, D. H.; Figdor, C. G.; Adema, G. J.; Punt, C. J. A. Crit. Rev. Oncol. Hematol. 2008, 66, 118-134.

(68) Petersen, T. R.; Sika-Paotonu, D.; Knight, D. A.; Dickgreber, N.; Farrand, K. J.; Ronchese, F.; Hermans, I. F. Immmunol. Cell Biol. 2010, 88, 596604.

(69) Bendelac, A.; Savage, P. B.; Teyton, L. Annu. Rev. Immunol. 2006, 25, 297-336.

(70) Godfrey, D. I.; Berzins, S. P. Nat. Rev. Immunol. 2007, 7, 505-518.

(71) Silk, J. D.; Salio, M.; Brown, J.; Jones, E. Y.; Cerundolo, V. Annu. Rev. Cell. Dev. Bi. 2008, 24, 369-395.

(72) Bendelac, A.; Savage, P. B.; Teyton, L. Annu. Rev. Immunol. 2007, 25, 297-336.

(73) Koch, M.; Stronge, V. S.; Shepherd, D.; Gadola, S. D.; Mathew, B.; Ritter, G.; Fersht, A. R.; Besra, G. S.; Schmidt, R. R.; Jones, E. Y.; Cerundolo, V. Nat. Immunol. 2005, 6, 819-826.

(74) Godfrey, D. I.; Kronenberg, M. J. Clin. Invest. 2004, 114, 1379-1388.

(75) Brossay, L.; Chioda, M.; Burdin, N.; Koezuka, Y.; Casorati, G.; Dellabona, P.; Kronenberg, M. J. Exp. Med. 1998, 188, 1521-1528.

(76) Godfrey, D. I.; McCluskey, J.; Rossjohn, J. Nat. Immunol. 2005, 6, 754756. 
(77) Silk, J. D.; Hermans, I. F.; Gileadi, U.; Chong, T. W.; Shepherd, D.; Salio, M.; Mathew, B.; Schmidt, R. R.; Lunt, S. J.; Williams, K. J.; Stratford, I. J.; Harris, A. L.; Cerundolo, V. J. Clin. Invest. 2004, 114, 1800-1811.

(78) Acuto, O.; Michel, F. Nat. Rev. Immunol. 2003, 3, 939-951.

(79) Natori, T.; Koezuka, Y.; Higa, T. Tetrahedron Lett. 1993, 34, 5591-5592.

(80) Natori, T.; Morita, M.; Akimoto, K.; Koezuka, Y. Tetrahedron 1994, 50, 2771-2784.

(81) Morita, M.; Motoki, K.; Akimoto, K.; Natori, T.; Sakai, T.; Sawa, E.; Yamaji, K.; Koezuka, Y.; Kobayashi, E.; Fukushima, H. J. Med. Chem. 1995, 38, 2176-2187.

(82) Kawano, T.; Cui, J.; Koezuka, Y.; Toura, I.; Kaneko, Y.; Motoki, K.; Ueno, H.; Nakagawa, R.; Sato, H.; Kondo, E.; Koseki, H.; Taniguchi, M. Science 1997, 278, 1626-1629.

(83) Fujio, M.; Wu, D.; Garcia-Navarro, R.; Ho, D. D.; Tsuji, M.; Wong, C.-J. J. Am. Chem. Soc. 2006, 128, 9022-9023.

(84) Schiefner, A.; Fujio, M.; Wu, D.; Wong, C.-H.; Wilson, I. A. J. Mol. Biol. 2009, 394, 71-82.

(85) Park, J.-J.; Lee, J. H.; Ghosh, S. C.; Bricard, G.; Venkataswamy, M. M.; Porcelli, S. A.; Chung, S.-K. Bioorg. Med. Chem. Lett. 2008, 18, 39063909.

(86) Tashiro, T.; Hongo, N.; Nakagawa, R.; Seino, K.; Watarai, H.; Ishii, Y.; Taniguchi, M.; Mori, K. Bioorg. Med. Chem. 2008, 16, 8896-8906.

(87) McCarthy, C.; Shepherd, D.; Fleire, S.; Stronge, V. S.; Koch, M.; Illarionov, P. A.; Bossi, G.; Salio, M.; Denkberg, G.; Reddington, F.; Tarlton, A.; Reddy, B. G.; Schmidt, R. R.; Reiter, Y.; Griffiths, G. M.; Van Der Merwe, P. A.; Besra, G. S.; Jones, E. Y.; Batista, F. D.; Cerundolo, V. J. Exp. Med. 2007, 204, 1131-1144.

(88) Schmieg, J.; Yang, G.; Franck, R. W.; Tsuji, M. J. Exp. Med. 2003, 198, 1631-1641.

(89) Chen, G.; Schmieg, J.; Tsuji, M.; Franck, R. W. Org. Lett. 2004, 6, 40774080.

(90) Li, X.; Chen, G.; Garcia-Navarro, R.; Franck, R. W.; Tsuji, M. Immunology 2008, 127, 216-225.

(91) Li, X.; Shiratsuchi, T.; Chen, G.; Dellabona, P.; Casorati, G.; Franck, R. W.; Tsuji, M. J. Immunol. 2009, 183, 4415-4421.

(92) Veerapen, N.; Brigl, M.; Garg, S.; Cerundolo, V.; Cox, L. R.; Brenner, M. B.; Besra, G. S. Bioorg. Med. Chem. Lett. 2009, 19, 4288-4291.

(93) Zhou, D.; Mattner, J.; Cantu III, C.; Schrantz, N.; Yin, N.; Gao, Y.; Sagiv, Y.; Hudspeth, K.; Wu, Y.-P.; Yamashita, T.; Teneberg, S.; Wang, D.; Proia, R. L.; Levery, S. B.; Savage, P. B.; Teyton, L.; Bendelac, A. Science 2004, 306, 1786-1789.

(94) Zajonc, D. M.; Savage, P. B.; Bendelac, A.; Wilson, I. A.; Teyton, L. J. Mol. Biol. 2008, 377, 1104-1116.

(95) Hollán, S. Haematologia 2000, 30, 237-252.

(96) Cooling, L. L. W.; Zhang, D. S.; Naides, S. J.; Koerner, T. A. W. Blood 2003, 101, 711-721.

(97) Godfrey, D. I.; McConville, M. J.; Pellicci, D. G. J. Exp. Med. 2006, 203, 2229-2232.

(98) Porubsky, S.; Speak, A. O.; Luckow, B.; Cerundolo, V.; Platt, F. M.; Grone, H.-J. Proc. Natl. Acad. Sci. 2007, 104, 5977-5982. 
(99) Christiansen, D.; Milland, J.; Mouhtouris, E.; Vaughan, H.; Pellicci, D. V.; McConville, M. J.; Godfrey, D. I.; Sandrin, M. S. Plos. Biol. 2008, 6, e172 $(1-12)$.

(100) Chen, W.; Xia, C.; Wang, J.; Thapa, P.; Li, Y.; Nadas, J.; Zhang, W.; Zhou, D.; Wang, P. G. J. Org. Chem. 2007, 72, 9914-9923.

(101) Xia, C.; Schmann, J.; Emmanuel, R.; Zhang, Y.; Chen, W.; Zhang, W.; Libero, G. D.; Wang, P. G. J. Med. Chem. 2009, 50, 3489-3495.

(102) Yin, N.; Long, X.; Goff, R. D.; Zhou, D.; Cantu III, C.; Mattner, J.; Saint Mezard, P.; Teyton, L.; Bendelac, A.; Savage, P. B. ACS Chem. Biol. 2009, 4, 191-197.

(103) Brossay, L.; Naidenko, O.; Burdin, N.; Matsuda, J.; Sakai, T.; Kronenberg, M. J. Immunol. 1998, 161, 5124-5128.

(104) Lacône, V.; Hanault, J.; Pipelier, M.; Blot, V.; Lecourt, T.; Rocher, J.; Turcot-Dudois, A.-L.; Marionneau, S.; Douillard, J.-Y.; Clément, M.; Le Pendu, J.; Bonneville, M.; Micouin, L.; Dubreuil, D. J. Med. Chem. 2009, $52,4960-4963$.

(105) Plettenburg, O.; Bodmer-Narkevitch, V.; Wong, C.-H. J. Org. Chem. 2002, 67, 4559-4564.

(106) Xia, C.; Yao, Q.; Schümann, J.; Rossy, E.; Chen, W.; Zhu, L.; Zhang, W.; De Libero, G.; Wang, P. G. Bioorg. Med. Chem. Lett. 2006, 16, $2195-$ 2199.

(107) Morales-Serna, J. A.; Boutureira, O.; Díaz, Y.; Matheu, M. I.; Castillón, S. Carbohydr. Res. 2007, 342, 1595-1612.

(108) Ndonye, R. M.; Izmirian, D. P.; Dunn, M. F.; Yu, K. O. A.; Porcelli, S. A.; Khurana, A.; Kronenberg, M.; Richardson, S. K.; Howell, A. R. J. Org. Chem. 2005, 70, 10260-10270.

(109) Du, W.; Gervay-Hague, J. Org. Lett. 2005, 7, 2063-2065.

(110) Lee, A.; Farrand, K. J.; Dickgreber, N.; Hayman, C. M.; Jürs, S.; Hermans, I. F.; Painter, G. F. Carbohydr. Res. 2006, 341, 2785-2798.

(111) Zimmermann, P.; Schmidt, R. R. Liebigs Ann. Chem. 1988, 663-667.

(112) David, S.; Estramareix, B.; Fischer, J.-C.; Thérisod, M. J. Chem. Soc. Perkin Trans. 1 1982, 2131-2137.

(113) Inouye, S.; Tsuruoka, T.; Niida, T. J. Antibiot. 1966, 19, 288-292.

(114) Inouye, S.; Tsuruoka, T.; Ito, T.; Niida, T. Tetrahedron 1968, 23, 2125 2144.

(115) Yagi, M.; Kouno, T.; Aoyagi, Y.; Murai, H. Nippon Nogeikagaku Kaishi 1976, 50, 571-572.

(116) Paulsen, H.; Sangster, I.; Heyns, K. Chem. Ber. 1967, 100, 802-815.

(117) Koyama, M.; Sakamura, S. Agric. Biol. Chem. 1974, 38, 1111-1112.

(118) Fleet, G. W. J.; Smith, P. W. Tetrahedron Lett. 1985, 26, 1469-1472.

(119) Asano, N.; Oseki, K.; Kizu, H.; Matsui, K. J. Med. Chem. 1994, 37, 37013706.

(120) Kato, A.; Asano, N.; Kizu, H.; Matsui, K.; Watson, A. A.; Nash, R. J. J. Nat. Prod. 1997, 60, 312-314.

(121) Nojima, H.; Kimura, I.; Chen, F.; Sugihara, Y.; Haruno, M. J. Nat. Prod. 1998, 61, 397-400.

(122) Welter, A.; Jadot, J.; Dardenne, G.; Marlier, M.; Casimir, J. Phytochemistry 1976, 15, 747-749.

(123) Elbein, A. D.; Mitchell, M.; Sanford, B. A.; Fellows, L. E.; Evans, S. V. J. Biol. Chem. 1984, 259, 12409-12413. 
(124) Asano, N. Cell. Mol. Life Sci. 2009, 66, 1479-1492.

(125) Paulsen, H.; Brockhausen, I. Glycoconjugate J. 2001, 18, 867-870.

(126) Butters, T. D.; Dwek, R. A.; Platt, F. M. Glycobiology 2005, 15, 43R-52R.

(127) Bhowruth, V.; Alderwick, L. J.; Brown, A. K.; Bhatt, A.; Besra, G. S. Biochem. Soc. Trans 2008, 36, 555-565.

(128) Watson, A. A.; Fleet, G.; Asano, N.; Molyneux, R. J.; Nash, R. J. Phytochemistry 2001, 56, 265-295.

(129) Pearson, M. S. M.; Mathé-Allainmat, M.; Fargeas, V.; Lebreton, J. Eur. J. Org. Chem. 2005, 2159 - 2191.

(130) Afarinkia, K.; Bahar, A. Tetrahedron: Asymmetry 2005, 16, 1239-1287.

(131) Stocker, B. L.; Dangerfield, E. M.; Win-Mason, A. L.; Haslett, G. W.; Timmer, M. S. M. Eur. J. Org. Chem. 2010, 1615-1637.

(132) Asano, N.; Nash, R. J.; Molyneux, R. J.; Fleet, G. W. J. Tetrahedron: Asymmetry 2000, 11, $1645-1680$.

(133) Murphy, P. V. Eur. J. Org. Chem. 2007, 4177-4187.

(134) Merino, P.; Delso, I.; Tejero, T.; Cardona, F.; Marradi, M.; Faggi, E.; Parmeggiani, C.; Goti, A. Eur. J. Org. Chem. 2008, 2929-2947.

(135) Danoun, G.; Ceccon, J.; Greene, A. E.; Poisson, J.-F. Eur. J. Org. Chem. 2009, 4221-4224.

(136) Gupta, P.; Vankar, Y. D. Eur. J. Org. Chem. 2009, 1925-1933.

(137) Luo, S.-Y.; Kulkarni, S. S.; Chou, C.-H.; Liao, W.-M.; Hung, S.-C. J. Org. Chem. 2006, 71, 1226-1229.

(138) Doyagüez, E. G.; Calderón, F.; Sánchez, F.; Fernández-Mayoralas, A. J. Org. Chem. 2007, 72, 9353-9356.

(139) Young, I. S.; Baran, P. S. Nature Chem. 2009, 1, 193-205.

(140) Lindström, U. M.; Ding, R.; Hidestål, O. Chem. Commun. 2005, 17731774.

(141) Trost, B. M. Science 1991, 254, 1471-1477.

(142) Bernet, B.; Vasella, A. Helv. Chim. Acta. 1979, 62, 1990-2016.

(143) Bernet, B.; Vasella, A. Helv. Chim. Acta. 1979, 62, 2400-2410.

(144) Skaanderup, P. R.; Poulsen, C. S.; Hyldtoft, L.; Jørgensen, M. R.; Madsen, R. Synthesis 2002, 12, 1721-1727.

(145) Chamberlin, A. R.; Mulholland Jr, R. L.; Kahn, S. D.; Hehre, W. J. J. Am. Chem. Soc. 1987, 109, 672-677.

(146) Tredwell, M.; Luft, J. A. R.; Schuler, M.; Tenza, K.; Houk, K. N.; Gouverneur, V. Angew. Chem. Int. Ed. 2008, 47, 357-360.

(147) Inesi, A.; Mucciante, V.; Rossi, L. J. Org. Chem. 1998, 63, 1337-1338.

(148) Hassner, A.; Burke, S. S. Tetrahedron 1974, 30, 2613-2621.

(149) Bernet, B.; Vasella, A. Helv. Chim. Acta 1979, 62, 1990-2016.

(150) Kumar, V.; Gauniyal, H. M.; Shaw, A. K. Tetrahedron: Asymmetry 2007, 18, 2069-2078.

(151) Fourrière, G.; Van Hijfte, N.; Lalot, J.; Dutech, G.; Fragnet, B.; Coadou, G.; Quirion, J.-C.; Leclerc, E. Tetrahedron 2010, 66, 3963-3972.

(152) Ovaa, H.; Codée, J. D. C.; Lastdrager, B.; Overkleeft, H. S.; van der Marel, G. A.; Boom, J. H. Tetrahedron Lett. 1999, 40, 5063-5066.

(153) Skaanderup, P. R.; Hyldtoft, L.; Madsen, R. Monatsh. Chem. 2002, 133, 467-472.

(154) Ramana, C. V.; Khaladkar, T. P.; Chatterjee, S.; Gurjar, M. K. J. Org. Chem. 2008, 73, 3817-3822.

(155) Fürstner, A.; Weidmann, H. J. Org. Chem. 1989, 54, 2307-2311. 
(156) Kagan, F.; Rebenstorf, M. A.; Heinzelman, R. V. J. Am. Chem. Soc. 1957, 79, 3541-3544.

(157) Lauritsen, A.; Madsen, R. Org. Biomol. Chem. 2006, 4, 2898-2905.

(158) Sharma, S. K.; Songster, M. F.; Colpitts, T. L.; Hegyes, P.; Barany, G.; Castellino, F. J. J. Org. Chem. 1993, 58, 4993-4996.

(159) Borch, R. F.; Bernstein, M. D.; Durst, H. D. J. Am. Chem. Soc. 1971, 93, 2897-2904.

(160) Baxter, E.; Reitz, A. Organic Reactions 2002, 59, 1-714.

(161) Gomez, S.; Peters, J. A.; Maschmeyer, T. Adv. Synth. Catal. 2002, 344, 1037-1057.

(162) Bódis, J.; Lefferts, L.; Müller, T. E.; Pestman, R.; Lercher, J. A. Catal. Lett. 2005, 104, 23-28.

(163) Bowles, P.; Clayden, J.; Helliwell, M.; McCarthy, C.; Tomkinson, M.; Westlund, N. J. Chem. Soc. Perk. Trans. 1 1997, 2607-2616.

(164) Pelter, A.; Rosser, R. M.; Mills, S. J. Chem. Soc. Perk. Trans. 1 1984, 717-720.

(165) Miriyala, B.; Bhattacharyya, S.; Williamson, J. S. Tetrahedron 2004, 60, 1463-1471. 


\section{Chapter 2: The Synthesis of $\alpha$-GalCer Analogues}

\subsection{Introduction}

The glycolipid $\alpha$-GalCer (1, Figure 2.1$)$ is a potent iNKT cell ligand that is used to boost anti-tumour immune responses during therapeutic cancer vaccination. The $\alpha$-GalCer phytosphingosine lipid possesses a hydroxyl on the 4-position. To date the importance of this hydroxyl for human iNKT cell activation has been strongly debated. $\alpha$-GalCer demonstrates potent activity toward both human and murine iNKT cells. In contrast, a number of studies have suggested that the activity of $\alpha$-GalCer sphinganine analogue 2 (Figure 2.1) was significantly reduced in humans, although in mice, its activity was comparable to $\alpha$-GalCer. ${ }^{1,2}$ In 2008, Dubreuil and co-workers challenged this species-specific activity by reporting that $\mathbf{1}$ and $\mathbf{2}$ induced comparable human iNKT cell activation. ${ }^{2}$ To shed light on this and identify the optimal ceramide backbone for human iNKT cell activation, we wanted to synthesise the 4-deoxy $\alpha$-GalCer analogues $\mathbf{2}$ and $\mathbf{3}$ (Figure 2.1) containing the sphinganine and sphingosine ceramides. These would then be tested for their ability to activate both murine and human iNKT cells (see Chapter 3 for biological analysis). To date, the $\alpha$-GalCer sphingosine analogue 3 has not been synthesised and investigated for its ability to activate iNKT cells. 


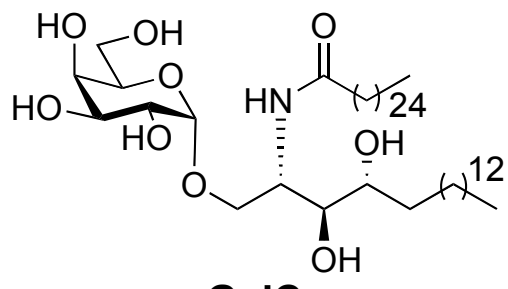

$\alpha$-GalCer

1

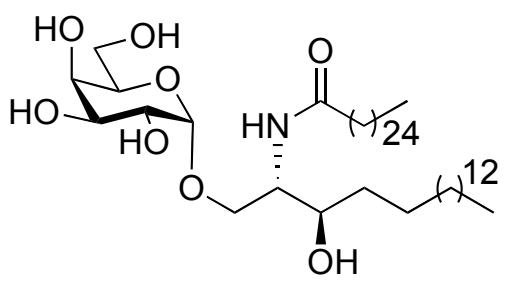

$\alpha$-GalCer analogue with sphinganine lipid 2

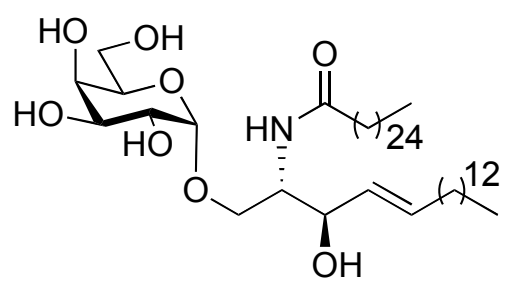

$\alpha$-GalCer analogue with sphingosine lipid 3

Figure 2.1. $\alpha$-GalCer and the target sphinganine and sphingosine analogues.

\subsection{Synthesis of $\alpha-G a l C e r$ Analogues}

To synthesise sphinganine $\mathbf{2}$ and sphingosine $\mathbf{3}$ a convergent strategy was proposed whereby the late stage building block $\mathbf{4}$ could be converted into either glycolipid (Scheme 2.1). Here, hydrogenation reaction or birch reduction would give sphinganine $\mathbf{2}$ or sphingosine $\mathbf{3}$ respectively. The fully protected glycolipid $\mathbf{4}$ could be accessed via the coupling of galactosyl donor $\mathbf{5}$ and mono-lipid acceptor 6. Although it is possible to couple the complete ceramide lipid to a donor substrate, amides reduce the nucleophilicity of the primary hydroxyl, via hydrogen bond donation and thus reduce the yield of the glycosylation reaction. ${ }^{3,4}$ Galactose donor 5 could in turn be prepared from D-galactose (7), ${ }^{5}$ and lipid acceptor 6 from aldehyde 8 and phosphorane 9 through the use of a Wittig reaction. ${ }^{6}$ Aldehyde $\mathbf{8}$ could be synthesised in 3 steps from D-arabinose (10), ${ }^{7}$ and phosphorane 9 prepared from commercially available bromotetradecane. 


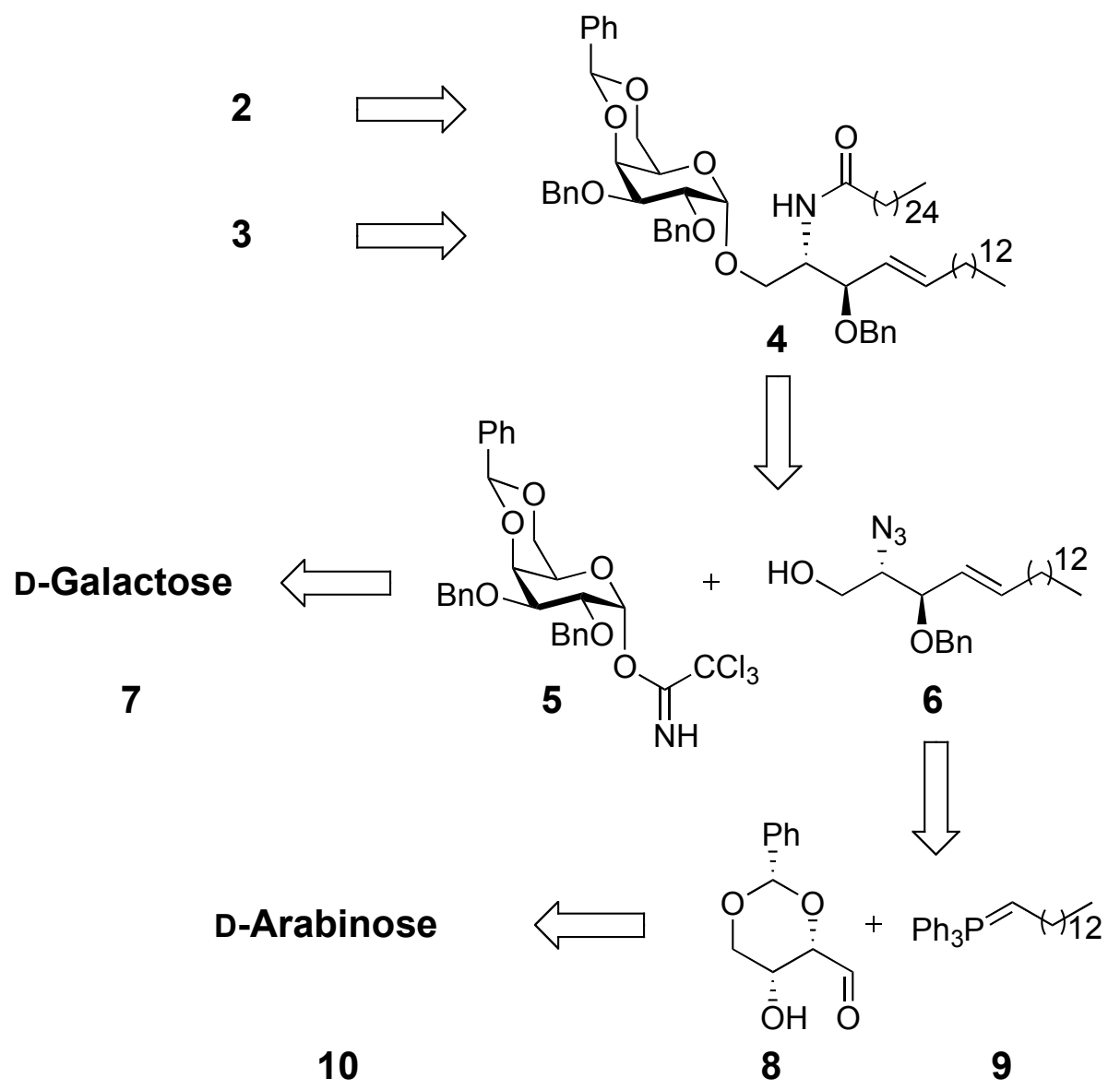

Scheme 2.1. Retrosynthesis of target sphinganine and sphingosine $\alpha$-GalCer analogues.

To prepare the desired trichloroacetimidate donor 5, D-galactose (7) was peracetylated then subjected to thiophenyl glycosylation followed by deacetylation using sodium methoxide to give thiogalactoside 11 (Scheme 2.2). The C-4 and C-6 hydroxyls were then protected with a benzylidene tether so as to allow for selective $\alpha$-glycosylation. ${ }^{5,8}$ Benzylation gave the fully protected dibenzylgalactoside 12 in 53\% yield (two steps). The thioglycoside donor was then convereted to a trichloroacetimidate leaving group. While thioglycosides are good donors their activation required the use of NIS. The use of NIS with lipid acceptor 6 would be likely to result in intramolecular iodocyclisation to form the corresponding five membered ring. Hydrolysis of thioglycoside 12 using TFA and NIS $^{9}$ only provided 71\% yield of lactol 13. TLC analysis of the crude reaction mixture revealed the presence of a higher running product, which was isolated and characterised using ${ }^{1} \mathrm{H},{ }^{19} \mathrm{~F}$ and $2 \mathrm{D}$ NMR spectroscopy. The reaction by-product was determined to be TFA 
derivative 14, which gave a distinctive ${ }^{1} \mathrm{H}$ NMR anomeric shift at $6.56 \mathrm{ppm}(J$ $=3.6 \mathrm{~Hz}$ ) and a signal in the ${ }^{19} \mathrm{~F}$ NMR at $-75 \mathrm{ppm}$. To improve the yield of lactol formation, thioglycoside $\mathbf{1 2}$ was subjected to NBS in acetone and lactol 13 was obtained in excellent (99\%) yield. ${ }^{10}$ Conversion of the anomeric hydroxyl to a trichloroacetimidate leaving group then afforded final galactose donor 5 in $81 \%$ yield.
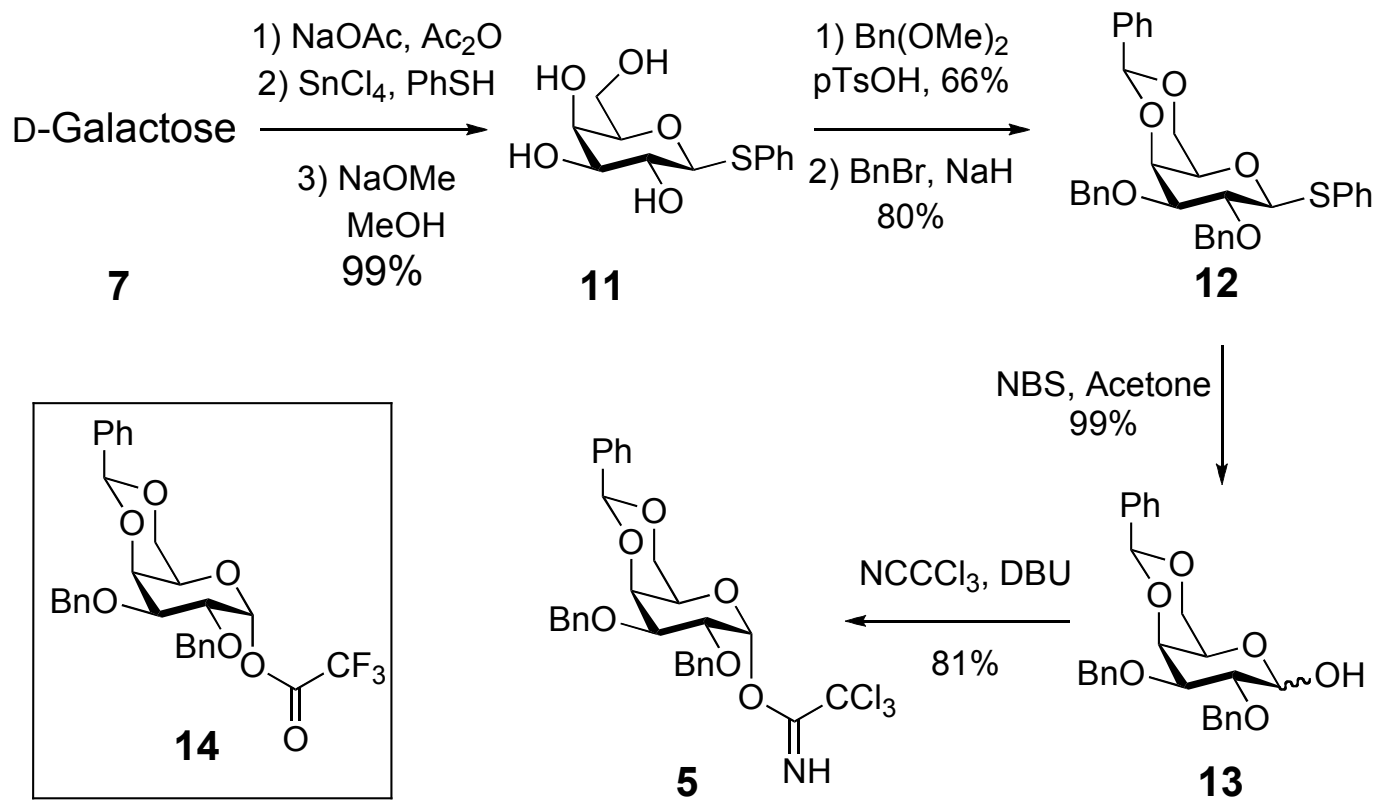

Scheme 2.2. Synthesis of trichloroacetimidate donor 5 .

The synthesis of lipid building block 6 commenced with $\mathrm{NaBH}_{4}$ reduction of Darabinose (10) to give the corresponding pentol which was subsequently protected with a benzylidene group to give triol 15 (Scheme 2.3). ${ }^{7}$ Sodium periodate cleavage of triol 15 gave aldehyde $\mathbf{8}$. This hydroxy aldehyde readily polymerised and accordingly it was important to react aldehyde $\mathbf{8}$ immediately to improve the yield of the Wittig reaction. Reaction of bromotetradecane (16) with $\mathrm{PPh}_{3}$ gave phosphonium salt 17 which could be crystallised using dry acetone and diethyl ether and stored under nitrogen. Wittig metathesis was then conducted to install the $E$-alkene and synthesise the full length C-18 ceramide backbone. First, phosphonium salt 17 was deprotonated using phenyllithium to give phosphorane 9 as an orange solution. Reaction of aldehyde 8 with phosphorane 9 using the Schlosser modification ${ }^{11,12}$ as adapted by Schmidt and co-workers, ${ }^{6}$ then gave alkene 18 as a mixture of $E$ and $Z$ isomers (4:1, 77\% yield). These isomers could 
be separated at this stage using repeated silica gel column chromatography (DCM/Hexanes, 1/1, vv). Alternatively, the $E / Z$ mixture of alkenes could be converted to hydroxyazide $\mathbf{6}$ (vide infra), which allowed for easier chromatographic separation of the isomers.
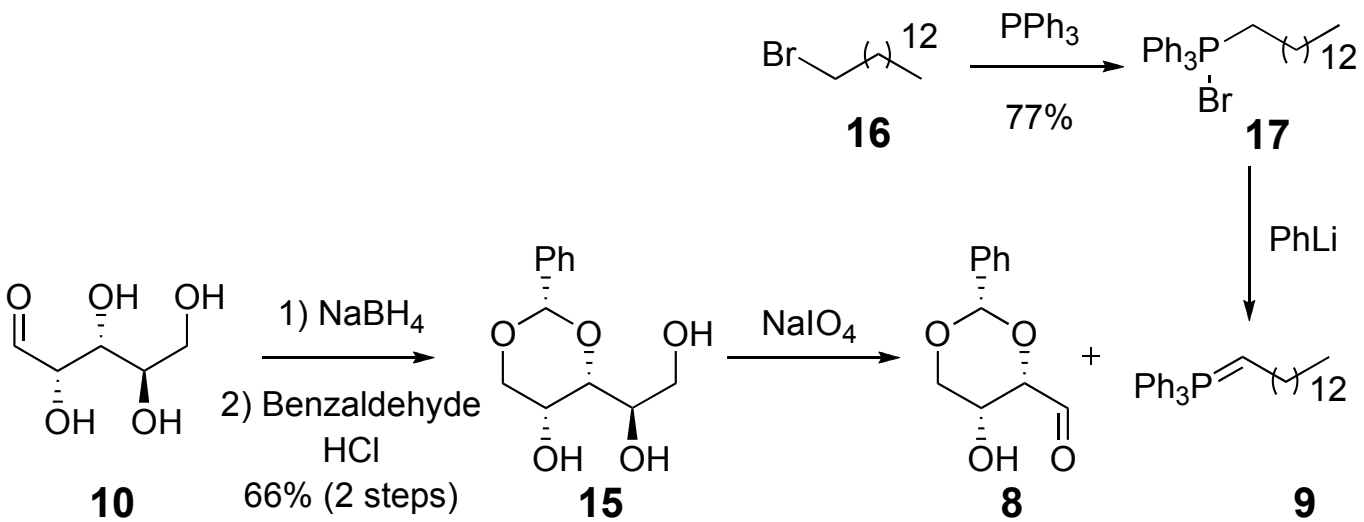
$77 \%$ (from 15)<smiles>[Y12]CC=C[C@H]1O[C@@H](c2ccccc2)OC[C@H]1O</smiles>

22

1) $\mathrm{TrCl}$

2) $\mathrm{BnBr}, \mathrm{NaH}$

3) TFA, TES $69 \%$ (3 steps)

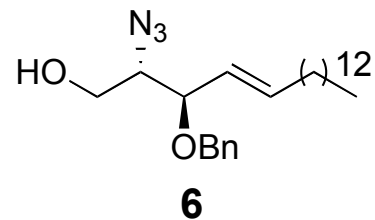<smiles>[Y10]CC=CC1=CCOC(c2ccccc2)O1</smiles>

20<smiles>N/C=C/C(=O)CCO[C@H](O)c1ccccc1</smiles>

21

Scheme 2.3. Synthesis of lipid building block 6 .

Wittig reaction of an unstabilized ylide usually leads to the formation of the $Z$ product. To explain the preferential formation of the $E$-alkene during the synthesis of lipid $\mathbf{1 8}$ it is important to consider the theory behind the Schlosser 
modification. In this procedure an excess (3.6 eq.) of alkyllithium base is used, this leads to the formation of lithium halide complexes and allows the $E$-isomer to form (Scheme 2.4). When an ylide (II) reacts with an aldehyde (I) at low temperatures $\left(-30{ }^{\circ} \mathrm{C}\right)$, it is presumed that a diastereomeric mixture of betainelithium halide complexes is formed (IIIa and b). At $-30{ }^{\circ} \mathrm{C}$ fragmentation of this complex to the alkene does not occur. Treatment of the complex with a strong base, such as phenyllithium, results in the formation of a $\beta$-oxide ylide complex (IV), which when protonated gives the more stable anti-betaine lithium halide complex (V). Once the anti-betaine lithium halide complex has formed the reaction is then warmed to room temperature, which releases the $E$-alkene (VI).
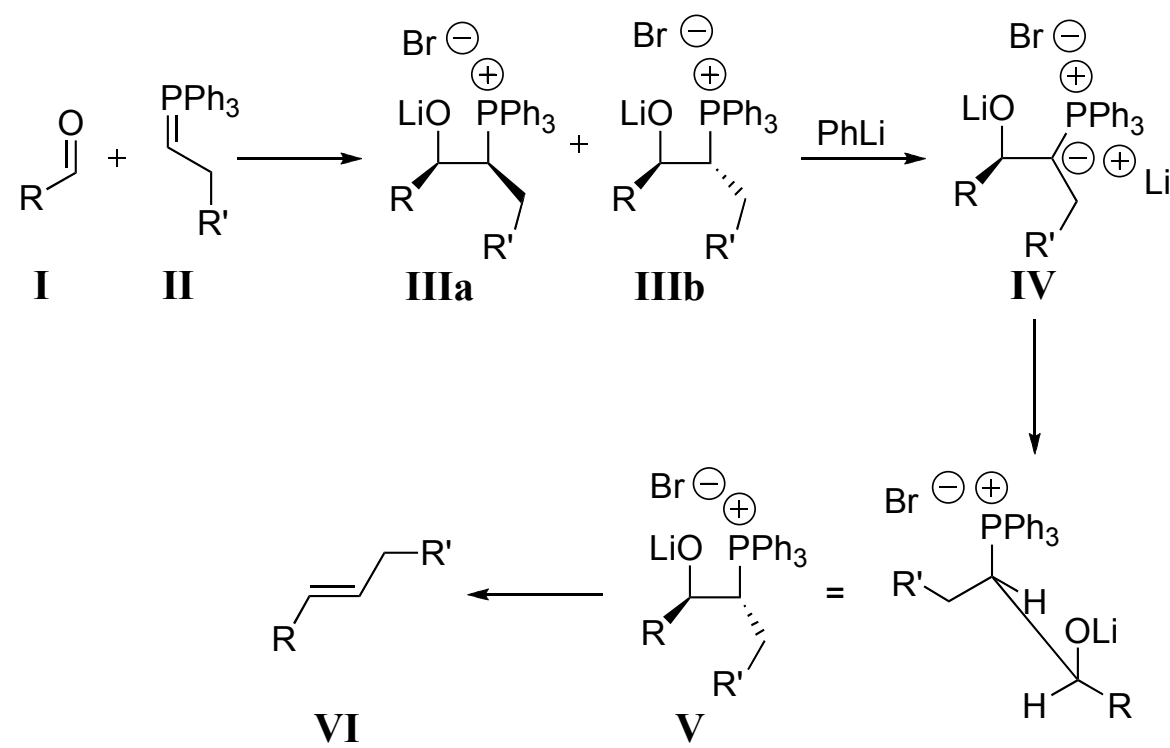

Scheme 2.4. Schlosser modification to the Wittig reaction affording $E$-alkenes.

Having prepared the required alkene 18 the C-2 hydroxyl was then converted to a triflate leaving group to enable $\mathrm{NaN}_{3} \mathrm{~S}_{\mathrm{N}} 2$ substitution to give azidooctadecene 19 . Initial attempts at carrying out this transformation on a small scale $(100 \mathrm{mg})$ were unsuccessful and only a small quantity of product was observed. Several by products, including the putatively assigned ketone $\mathbf{2 1}$, were observed. It is likely that ketone 21 was formed via E2 elimination of the triflate intermediate to give diene 20. Hydrolysis of 20, would then result in the formation of ketone $\mathbf{2 1}$. When the scale of the reaction was increased to a minimum of $1.0 \mathrm{~g}$ of alkene $\mathbf{1 8}$ azidooctadecene 19 was obtained in $77 \%$ yield, consistent with that reported by Schmidt and co-workers. ${ }^{6}$ With azidooctadecene 19 in hand the benzylidene 
acetal was removed using $p \mathrm{TsOH}$ to give lipid diol 22 in $90 \%$ yield. Next we wanted to determine whether it was necessary to protect the secondary hydroxyl during coupling of the lipid building block to the carbohydrate donor. Accordingly lipid 22 was reacted with imidate donor 5 (Scheme 2.2), however, a 1:1 mixture of 1-OH:3-OH coupled products were observed. Although primary hydroxyls are typically more reactive than secondary hydroxyls, in this example the 3-OH is at the allylic position. This increases the reactivity of the secondary hydroxyl rendering the nucleophilicity of two hydroxyls comparable. Thus trityl protection of the primary hydroxyl, benzyl protection of the allylic alcohol, and subsequent detritylation was necessary to complete the synthesis of the final lipid building block $\mathbf{6}$ ready for coupling.

With the required galactose trichloroacetimidate donor $\mathbf{5}$ and lipid acceptor $\mathbf{6}$ in hand, a $\mathrm{BF}_{3} . \mathrm{OEt}_{2}$ mediated glycosylation reaction was attempted. This proceeded smoothly, and ${ }^{1} \mathrm{H}$ NMR analysis revealed an anomeric coupling constant of 3.4 $\mathrm{Hz}$ indicating that only the $\alpha$-isomer 23 was formed in good (65\%) yield (Scheme 2.5). Staudinger reduction of the $\mathrm{C}-2$ azide using $\mathrm{PMe}_{3}$, followed by coupling to hexacosanoic acid then gave key building block 4 in 83\% yield over the two steps. Removal of the benzylidene protecting group, using acetic acid and water gave glycolipid 24, which was subjected to $\mathrm{Pd}(\mathrm{OH})_{2}$ to give $\alpha$-GalCer sphinganine $\mathbf{2}$ in a $98 \%$ yield over two steps. Alternatively, Birch reduction of the fully protected glycolipid 4 gave $\alpha$-GalCer sphingosine 3 in $97 \%$ yield. Due to the amphiphilic nature of glycolipids $\mathbf{2}$ and $\mathbf{3}$ deuterated pyridine was used for NMR characterisation. The full characterisation data was in agreement with literature values for analogous glycolipids with shorter acyl chains (see appendix for NMR spectra of final glycolipids). ${ }^{13,14}$ 


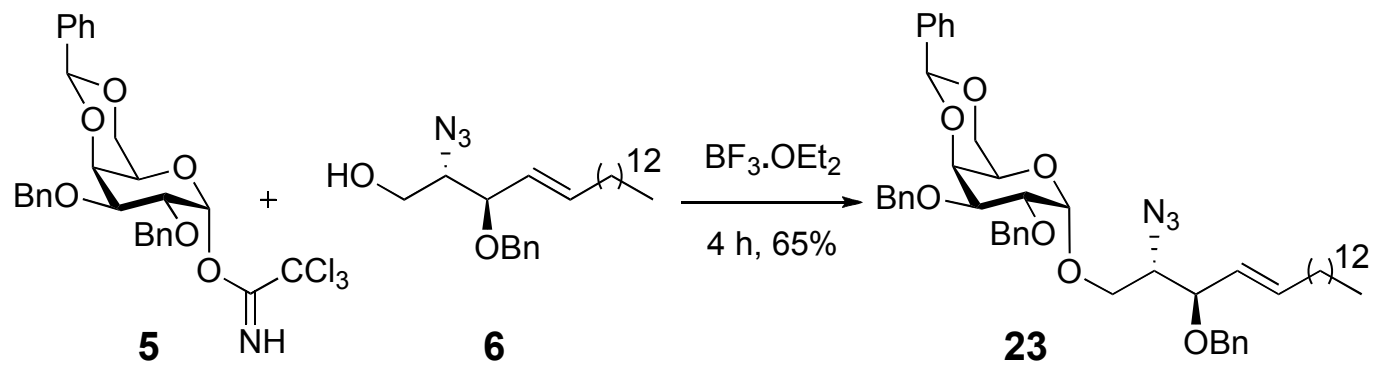

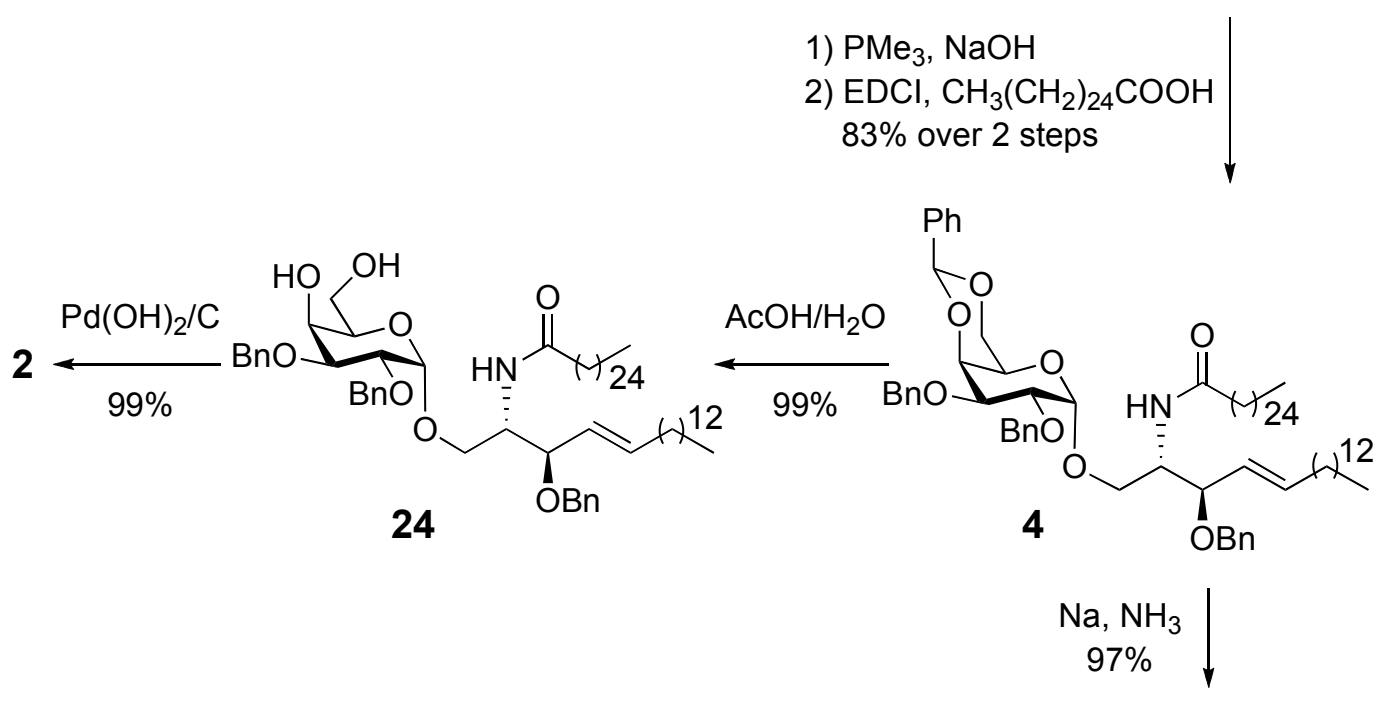

Scheme 2.5. Total synthesis of $\alpha$-GalCer analogues 2 and 3 .

\subsection{Conclusion}

In this work, two $\alpha$-GalCer analogues were synthesised from carbohydrate starting materials using a convergent strategy. $\alpha$-GalCer sphinganine derivative $\mathbf{2}$ was synthesised in 14 steps (longest linear sequence) from D-arabinose, and in an overall 13\% yield. $\alpha$-GalCer sphingosine analogue 3 was synthesised in 13 steps (longest linear sequence) also with an overall yield of $13 \%$. 


\subsection{Experimental}

\section{General procedure}

Unless otherwise stated all reactions were performed under a nitrogen atmosphere. THF (Lab-Scan) was distilled from $\mathrm{LiAlH}_{4}$ prior to use. $\mathrm{BF}_{3}$. $\mathrm{OEt}_{2}$ (Janssen Chimica), diethyl ether (Merck), $\mathrm{H}_{2} \mathrm{O}, \mathrm{PhBr}$ (Aldrich), and pyridine (Fischer Scientific), were distilled prior to use. Hexanes (Panreac), DMF (Acros), TES (Aldrich), $\mathrm{NaH}$ (Avocado), $\mathrm{BnBr}$ (Fluka), $\mathrm{TrCl}$ (Acros), $\mathrm{NaN}_{3}$ (BDH), $p \mathrm{TsOH}$ (Fluka), $\mathrm{Tf}_{2} \mathrm{O}$ (Sigma-Aldrich), Li (Aldrich), 1-bromotetradecane (Fluka), $\mathrm{NaIO}_{4}(\mathrm{M} \& \mathrm{~B})$, benzaldehyde (Unilab), $\mathrm{NaBH}_{4}$ (Aldrich), D-arabinose (Acros), Dgalactose (Sigma), NaOAc (Riedel-de Haën), $\mathrm{Ac}_{2} \mathrm{O}$ (Fluka), $\mathrm{SnCl}_{4}$ (Aldrich), $\mathrm{PhSH}$ (Koch-Light Laboratories), NaOMe (Chimica), Bn(OMe) 2 (Aldrich), NBS (Aldrich), Acetone (Pure Science), $\mathrm{NCCCl}_{3}$ (Aldrich), DBU (Merck), $\mathrm{PMe}_{3}$ (Aldrich), EDCI (Sigma), Hexacosanoic acid (Acros), $\mathrm{Pd} / \mathrm{OH}$ (Aldrich), $\mathrm{Na}$ (Aldrich), $\mathrm{NH}_{3}$ (BOC gasses), toluene (Panreac), $\mathrm{MeOH}$ (Pure Science), EtOAc (Pure Science), and Petroleum ether (Pure Science) EtOH (absolute, Pure Science), AcOH (Ajax Finechem), DCM (Panreac), TFA (Aldrich) $\mathrm{PPh}_{3}$ (Merck), and $\mathrm{NaOH}$ (Pure Science) were used as received. All solvents were removed by evaporation under reduced pressure. Reactions were monitored by TLC-analysis on Macherey-Nagel silica gel coated aluminium sheets $(0.20 \mathrm{~mm}$, silica gel 60$)$ with detection by UV-absorption (254 nm), by spraying with $20 \% \mathrm{H}_{2} \mathrm{SO}_{4}$ in EtOH followed by charring at $\sim 150{ }^{\circ} \mathrm{C}$, by dipping in $\mathrm{I}_{2}$ in silica, or by spraying with a solution of ninhydrin in EtOH followed by charring at $\sim 150{ }^{\circ} \mathrm{C}$. Column chromatography was performed on Pure Science silica gel (40-63 micron). Dowex ${ }^{\circledR}$ W50-X8 acidic resin (Sigma) and Dowex ${ }^{\circledR} 1$ X4-50 basic resin (Sigma) were used for ion exchange chromatography. High-resolution mass spectra were recorded on a Waters Q-TOF Premier ${ }^{\mathrm{TM}}$ Tandem Mass Spectrometer using positive electro-spray ionisation. Optical rotations were recorded using a PerkinElmer 241 polarimeter at the sodium D-line. Infrared spectra were recorded as thin films using a Bruker Tensor 27 FTIR spectrometer, equipped with an Attenuated Total Reflectance (ATR) sampling accessory, and are reported in wave numbers $\left(\mathrm{cm}^{-1}\right)$. Nuclear magnetic resonance spectra were recorded at $20^{\circ} \mathrm{C}$ in $\mathrm{D}_{2} \mathrm{O}, \mathrm{CDCl}_{3}, \mathrm{CD}_{3} \mathrm{OD}$ or pyridine- $\mathrm{d}_{6}$ using either a Varian Unity-INOVA operating at $300 \mathrm{MHz}$ or a Varian Unity operating at $500 \mathrm{MHz}$. Chemical shifts 
are given in ppm $(\delta)$ relative to tetramethylsilane. NMR peak assignments were made using COSY, HSQC and HMBC experiments.

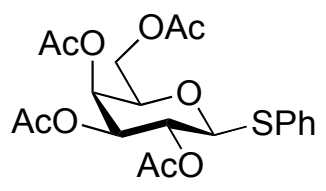

galactopyranoside. To a solution of $1,2,3,4,6$-penta- $O$-acetyl- $\beta$-Dgalactopyranoside (15.0 g, $38.45 \mathrm{mmol}$, co-evaporated twice with dry toluene), in dry DCM $(150 \mathrm{~mL})$ at $0{ }^{\circ} \mathrm{C}$, thiophenol $(4.75 \mathrm{~mL}, 5.08 \mathrm{~g}, 46.14 \mathrm{mmol})$ followed by tin(IV) chloride $(0.45 \mathrm{~mL}, 1.0 \mathrm{~g}, 3.85 \mathrm{mmol})$ were added and the resulting mixture stirred for $3 \mathrm{~h}$. The reaction was quenched with $3 \mathrm{M}$ aq. KF $(100 \mathrm{~mL})$ and the organic layer was washed with water $(100 \mathrm{~mL})$, sat. aq. $\mathrm{NaHCO}_{3}(100 \mathrm{~mL})$, and brine $(100 \mathrm{~mL})$, dried over $\mathrm{MgSO}_{4}$, filtered and concentrated under reduced pressure. The resulting oil was purified by flash chromatography mixed with $10 \%$ crushed KF (Petroleum ether/EtOAc, 2/1, v/v) to give phenyl 2,3,4,6-tetra- $O$ acetyl-1-thio- $\beta$-D-galactopyranoside as a colourless oil $(99 \%, 16.75 \mathrm{~g}, 38.07$ mmol). $[\alpha]^{23}=+4.0\left(c=1.0, \mathrm{CHCl}_{3}\right)$; IR (film) 3060, 2917, 2849, 2400, 2000, $1747,1583,1480,1439,1369,1200,1054,917,736,702 \mathrm{~cm}^{-1} ;{ }^{1} \mathrm{H}$ NMR (500 $\left.\mathrm{MHz}, \mathrm{CDCl}_{3}\right) \delta 7.51(\mathrm{~m}, 2 \mathrm{H}, \mathrm{CH}-o \mathrm{Ph}), 7.31(\mathrm{~m}, 3 \mathrm{H}, \mathrm{CH}-m \mathrm{Ph}), 5.41$ (d, $J_{3,4}=$ $3.4 \mathrm{~Hz}, 1 \mathrm{H}, \mathrm{H}-4), 5.24\left(\mathrm{t}, J_{1,2}=J_{2,3}=10.0 \mathrm{~Hz}, 1 \mathrm{H}, \mathrm{H}-2\right), 5.05\left(\mathrm{dd}, J_{3,4}=3.4, J_{2,3}=\right.$ $10.0 \mathrm{~Hz}, 1 \mathrm{H}, \mathrm{H}-3), 4.72\left(\mathrm{~d}, J_{1,2}=10.0 \mathrm{~Hz}, 1 \mathrm{H}, \mathrm{H}-1\right), 4.18\left(\mathrm{dd}, J_{5,6 \mathrm{a}}=7.1, J_{6 \mathrm{a}, 6 \mathrm{~b}}=\right.$ $11.4 \mathrm{~Hz}, 1 \mathrm{H}, \mathrm{H}-6 \mathrm{a}), 4.11\left(\mathrm{dd}, J_{5,6 \mathrm{~b}}=6.2, J_{6 \mathrm{a}, 6 \mathrm{~b}}=11.4 \mathrm{~Hz}, 1 \mathrm{H}, \mathrm{H}-6 \mathrm{~b}\right), 3.94(\mathrm{dd}$, $\left.J_{5,6 \mathrm{~b}}=6.2, J_{5,6 \mathrm{a}}=7.1 \mathrm{~Hz}, 1 \mathrm{H}, \mathrm{H}-5\right), 2.11\left(\mathrm{~s}, 3 \mathrm{H}, \mathrm{OAc}-\underline{\mathrm{H}}_{3}\right), 2.09$ (s, 3H, OAc$\left.\mathrm{C}_{3}\right), 2.04$ (s, 3H, OAc-C $\left.\underline{H}_{3}\right), 1.97$ (s, 3H, OAc-C $\left.\underline{H}_{3}\right) ;{ }^{13} \mathrm{C} \mathrm{NMR}(125 \mathrm{MHz}$, $\left.\mathrm{CDCl}_{3}\right) \delta 170.4,170.2,170.1,169.4(\mathrm{OAc}-\underline{\mathrm{C}}=\mathrm{O}), 132.5(\mathrm{CH}-o \mathrm{Ph}) 132.5(\mathrm{C}-i \mathrm{Ph})$, 128.9 (CH-m Ph), 128.2 (CH-p Ph), 86.6 (C1), 74.4 (C5), 72.0 (C3), 67.22, 67.20 (C2 and C4), 61.6 (C6), $20.8\left(\mathrm{OAc}-\underline{\mathrm{H}}_{3}\right), 20.7\left(\mathrm{OAc}-\underline{\mathrm{C}} \mathrm{H}_{3}\right), 20.64\left(\mathrm{OAc}-\underline{\mathrm{CH}}_{3}\right)$, $20.59\left(\mathrm{OAc}-\underline{\mathrm{CH}}_{3}\right)$; HRMS(ESI) $\mathrm{m} / z$ calcd. for $\left[\mathrm{C}_{20} \mathrm{H}_{24} \mathrm{O}_{9} \mathrm{~S}+\mathrm{Na}\right]^{+}: 463.1033$, obsd.: 463.1034 . 


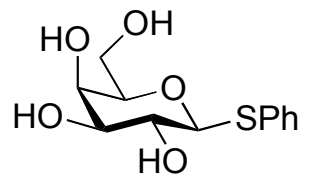

Phenyl 1-thio- $\beta$-D-galactopyranoside (11). To a solution of phenyl 2,3,4,6-tetra- $O$-acetyl-1-thio- $\beta$-D-galactopyranoside $(33.0 \mathrm{~g}, 74.98 \mathrm{mmol})$ in $\mathrm{MeOH}(375 \mathrm{~mL}), \mathrm{NaOMe}$ was added slowly until the solution reached a $\mathrm{pH}$ of 11. The reaction mixture was stirred $4 \mathrm{~h}$, neutralised with Dowex $\mathrm{H}^{+}$, filtered and concentrated under reduced pressure. The resulting oil was crystallized from EtOH/Petroleum ether to afford $\mathbf{1 1}$ as white fluffy crystals $(99 \%, 20.2$ g, 74.23 mmol). Mp $106.2-107.0{ }^{\circ} \mathrm{C} .[\alpha]^{21}{ }_{\mathrm{D}}=-37.0(c=0.1, \mathrm{MeOH})$; IR (film) 3383, 2895, 1583, 1480, 1439, 1057, 865, 743, $692 \mathrm{~cm}^{-1} ;{ }^{1} \mathrm{H}$ NMR (500 MHz, $\left.\mathrm{CD}_{3} \mathrm{OD}\right)$ $\delta$ 7.56-7.53 (m, 2H, CH-o Ph), 7.31-7.27 (m, 2H, CH-m Ph), 7.24-7.22 (m, 1H, $\mathrm{CH}-p \mathrm{Ph}), 4.60\left(\mathrm{~d}, J_{1,2}=9.7 \mathrm{~Hz}, 1 \mathrm{H}, \mathrm{H}-1\right), 3.91$ (bs, $\left.1 \mathrm{H}, \mathrm{H}-4\right), 3.77$ (dd, $J_{5,6 \mathrm{a}}=$ $\left.7.0, J_{6 \mathrm{a}, 6 \mathrm{~b}}=11.5 \mathrm{~Hz}, 1 \mathrm{H}, \mathrm{H}-6 \mathrm{a}\right), 3.72\left(\mathrm{dd}, J_{5,6 \mathrm{~b}}=5.5, J_{6 \mathrm{a}, 6 \mathrm{~b}}=11.5 \mathrm{~Hz}, 1 \mathrm{H}, \mathrm{H}-6 \mathrm{~b}\right)$, $3.60\left(\mathrm{t}, J_{1,2}=J_{2,3}=9.7 \mathrm{~Hz}, 1 \mathrm{H}, \mathrm{H}-2\right), 3.56\left(\mathrm{dd}, J_{5,6 \mathrm{~b}}=5.5, J_{5,6 \mathrm{a}}=7.0 \mathrm{~Hz}, 1 \mathrm{H}, \mathrm{H}-5\right)$, $3.49\left(\mathrm{dd}, J_{3,4}=3.0, J_{2,3}=9.5 \mathrm{~Hz}, 1 \mathrm{H}, \mathrm{H}-3\right) ;{ }^{13} \mathrm{C} \mathrm{NMR}\left(125 \mathrm{MHz}, \mathrm{CD}_{3} \mathrm{OD}\right) \delta$ 135.9 (C-i SPh) 131.9 (CH-o Ph), 129.8 (CH-m Ph), 127.9 (CH-p Ph), 90.2 (C1), 80.5 (C5), 76.2 (C3), 70.9 (C2), 70.3 (C4), 62.6 (C6); HRMS(ESI) m/z calcd. for $\left[\mathrm{C}_{12} \mathrm{H}_{16} \mathrm{O}_{5} \mathrm{~S}+\mathrm{Na}\right]^{+}:$295.0611, obsd.: 295.0613.

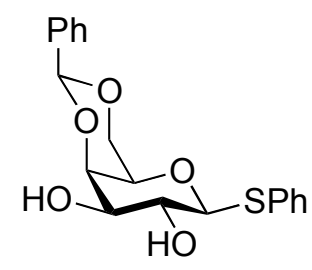

Phenyl 4,6- $O$-benzylidene-1-thio- $\beta$-D-galactopyranoside. To a solution of thioglycoside 11 ( $3.0 \mathrm{~g}, 11.03 \mathrm{mmol}$, co-evaporated twice with dry DMF, $30 \mathrm{~mL})$ dissolved in dry DMF $(180 \mathrm{~mL})$ under a nitrogen atmosphere, benzaldehyde dimethyl acetal $(11.5 \mathrm{~mL}, 76.6 \mathrm{mmol})$ was added followed by $p \mathrm{TsOH}(1.0 \mathrm{~g}, 5.1 \mathrm{mmol})$. The reaction mixture was stirred overnight at $\mathrm{rt}$ then neutralised with triethylamine and concentrated under reduced pressure. The residue was redissolved in EtOAc $(150 \mathrm{~mL})$ and washed with water $(150 \mathrm{~mL})$, sat. aq. $\mathrm{NaHCO}_{3}(150 \mathrm{~mL})$ and brine $(150 \mathrm{~mL})$, dried over $\mathrm{MgSO}_{4}$, filtered and concentrated under reduced pressure. Crystallisation from EtOAc/petroleum ether 
afforded phenyl 4,6-O-benzylidene-1-thio- $\beta$-D-galactopyranoside as fluffy white crystals $(66 \%, 2.62 \mathrm{~g}, 7.28 \mathrm{mmol}) . \mathrm{Mp} 154-156{ }^{\circ} \mathrm{C} ;[\alpha]^{22}{ }_{\mathrm{D}}=-34.5(c=1.0$, $\mathrm{CHCl}_{3}$ ); IR (film) 3401, 3061, 2976, 2869, 1583, 1480, 1451, 1439, 1362, 1098, 1070, 1041, 1027, 925, 898, 866, 734, $696 \mathrm{~cm}^{-1} ;{ }^{1} \mathrm{H}$ NMR (500 MHz, $\left.\mathrm{CDCl}_{3}\right) \delta$ $7.70(\mathrm{~m}, 2 \mathrm{H}$, aromatic), 7.40-7.29 (m, $8 \mathrm{H}$, aromatic), $5.52(\mathrm{~s}, 1 \mathrm{H}, \mathrm{CH}-\mathrm{Ph}), 4.52$ $\left(\mathrm{d}, J_{1,2}=9.0 \mathrm{~Hz}, 1 \mathrm{H}, \mathrm{H}-1\right), 4.40\left(\mathrm{~d}, J_{6 \mathrm{a}, 6 \mathrm{~b}}=12.5 \mathrm{~Hz}, 1 \mathrm{H}, \mathrm{H}-6 \mathrm{a}\right) 4.22\left(\mathrm{~d}, J_{3,4}=1.5\right.$ $\mathrm{Hz}, 1 \mathrm{H}, \mathrm{H}-4), 4.05$ (dd, $\left.J_{5,6 \mathrm{~b}}=1.0, J_{6 \mathrm{a}, 6 \mathrm{~b}}=12.5 \mathrm{~Hz}, 1 \mathrm{H}, \mathrm{H}-6 \mathrm{~b}\right), 3.71-3.70(\mathrm{~m}, 2 \mathrm{H}$,

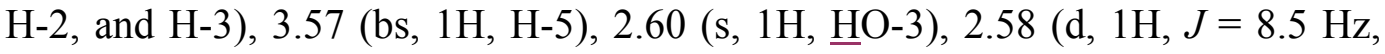
$\underline{\mathrm{HO}}-2) ;{ }^{13} \mathrm{C} \mathrm{NMR}\left(125 \mathrm{MHz}, \mathrm{CDCl}_{3}\right) \delta 137.5,130.6$ (quaternary C), 133.8, 129.4, 129.0, 128.3, $126.5(10 \mathrm{x}$ aromatic $\mathrm{C}), 101.4\left(\mathrm{PhCHO}_{2}\right), 87.0(\mathrm{C} 1), 75.3(\mathrm{C} 4)$, 73.8 (C2), 70.1 (C5), 69.3 (C6), 68.8 (C3); HRMS(ESI) $m / z$ calcd. for $\left[\mathrm{C}_{19} \mathrm{H}_{20} \mathrm{O}_{5} \mathrm{~S}+\mathrm{Na}\right]^{+}:$383.0924, obsd.: 383.0927.

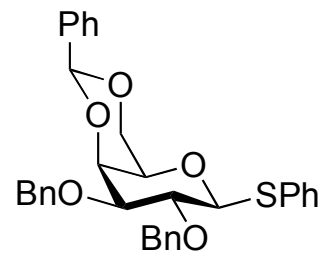

Phenyl 2,3-di- $O$-benzyl-4,6- $O$-benzylidene-1-thio- $\beta$-Dgalactopyranoside (12). To a solution of phenyl 4,6- $O$-benzylidene-1-thio- $\beta$-Dgalactopyranoside $(2.0 \mathrm{~g}, 5.55 \mathrm{mmol})$ in dry DMF $(25 \mathrm{~mL})$ at $0{ }^{\circ} \mathrm{C}$ was added $\operatorname{BnBr}(2.27 \mathrm{~g}, 1.6 \mathrm{~mL}, 13.3 \mathrm{mmol})$ followed by $\mathrm{NaH}$ (as a $60 \%$ mineral oil dispersion, $0.72 \mathrm{~g}, 18.0 \mathrm{mmol})$. The resulting solution was warmed to room temperature and stirred overnight, excess $\mathrm{NaH}$ was quenched using $\mathrm{MeOH}$, and the solvent was removed under reduced pressure. The syrup was redissolved in diethyl ether $(100 \mathrm{~mL})$ and washed twice with water $(100 \mathrm{~mL})$ and brine $(100$ $\mathrm{mL}$ ), dried over $\mathrm{MgSO}_{4}$, filtered and concentrated under reduced pressure. The product was crystallised from EtOAc/petroleum ether to afford $\mathbf{1 2}$ as white fluffy crystals $(80 \%, 2.39 \mathrm{~g}, 4.42 \mathrm{mmol}) . \mathrm{Mp} 171.2-171.9{ }^{\circ} \mathrm{C} ;[\alpha]^{22}{ }_{\mathrm{D}}=-18.9(c=1.0$, $\mathrm{CHCl}_{3}$ ); IR (film) 2817, 2849, 1977, 1584, 1453, 1399, 1092, 1057, 1026, 815, 759, 732, $696 \mathrm{~cm}^{-1} ;{ }^{1} \mathrm{H}$ NMR $\left(500 \mathrm{MHz}, \mathrm{CDCl}_{3}\right) \delta$ 7.73-7.71 (m, 2H, CH-o $\mathrm{PhCHO}_{2}$ ), 7.55-7.53 (m, 2H, CH-o SPh), 7.43-7.19 (m, 16H, aromatic H), 5.50 (s, 1H, $\left.\mathrm{PhCHO}_{2}\right), 4.72$ (m, 4H, Bn-2 and Bn-3), 4.63 (d, $\left.J_{1,2}=9.3 \mathrm{~Hz}, 1 \mathrm{H}, \mathrm{H}-1\right), 4.39$ 
$\left(\mathrm{d}, J_{6 \mathrm{a}, 6 \mathrm{~b}}=12.5 \mathrm{~Hz}, 1 \mathrm{H}, \mathrm{H}-6 \mathrm{a}\right), 4.17\left(\mathrm{~d}, J_{3,4}=3.4 \mathrm{~Hz}, 1 \mathrm{H}, \mathrm{H}-4\right), 4.01$ (dd, $J_{5,6 \mathrm{a}}=$ $\left.1.3, J_{6 \mathrm{a} .6 \mathrm{~b}}=12.5 \mathrm{~Hz}, 1 \mathrm{H}, \mathrm{H}-6 \mathrm{~b}\right), 3.91\left(\mathrm{t}, J_{1,2}=J_{2,3}=9.3 \mathrm{~Hz}, 1 \mathrm{H}, \mathrm{H}-2\right), 3.64(\mathrm{dd}$, $\left.J_{3,4}=3.4, J_{2,3}=9.3 \mathrm{~Hz}, 1 \mathrm{H}, \mathrm{H}-3\right), 3.44$ (bs, $\left.1 \mathrm{H}, \mathrm{H}-5\right) ;{ }^{13} \mathrm{C} \mathrm{NMR}(125 \mathrm{MHz}$, $\left.\mathrm{CDCl}_{3}\right) \delta 138.5,138.1,137.9$ (3 x quaternary C), $132.8(\mathrm{CH}-o \mathrm{SPh}), 132.7,129.1$, $128.9,128.4,128.4,128.24,128.19,127.8,127.7,127.5,126.6$ (aromatic C), $101.4\left(\mathrm{PhCHO}_{2}\right), 86.5$ (C1), 81.4 (C3), 75.5 (2-OCHPh), 75.4 (C2), 73.7 (C4), $71.9\left(3-\mathrm{OCH}_{2} \mathrm{Ph}\right), 69.9$ (C5), 69.4 (C6); HRMS(ESI) $m / z$ calcd. for $\left[\mathrm{C}_{33} \mathrm{H}_{32} \mathrm{O}_{5} \mathrm{~S}+\mathrm{Na}\right]^{+}:$563.1863, obsd.: 563.1871 .

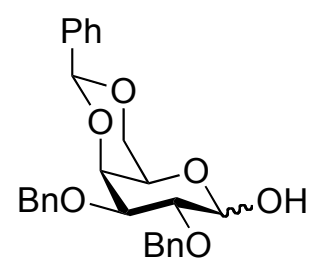

2,3-Di- $O$-benzyl-4,6- $O$-benzylidene-D-galactose (13). To a solution of thioglycoside $12(500 \mathrm{mg}, 0.925 \mathrm{mmol})$ in acetone $(18.5 \mathrm{~mL})$ and water $(1.85 \mathrm{~mL})$ NBS $(576 \mathrm{mg}, 3.24 \mathrm{mmol})$ was added and the reaction was stirred at room temperature for $15 \mathrm{~min}$. The reaction mixture was diluted with EtOAc $(45 \mathrm{ml})$, and washed sat. aq. $\mathrm{Na}_{2} \mathrm{~S}_{2} \mathrm{O}_{3}(50 \mathrm{~mL})$, water $(50 \mathrm{~mL})$ and brine (50 mL), dried over $\mathrm{MgSO}_{4}$ filtered and concentrated under reduced pressure. The resulting oil was purified by gradient flash chromatography (Petroleum ether/EtOAc, 5/1 to 0/100, v/v) then crystallised (Petroleum ether/EtOAc, 2/1, $\mathrm{v} / \mathrm{v})$ to give $\mathbf{1 3}$ as fluffy white crystals $(94 \%, 390 \mathrm{mg}, 0.870 \mathrm{mmol}) . \mathrm{R}_{f}=0.08$ (Petroleum ether/EtOAc, 5/1, v/v). Mp $=165.5-166.4{ }^{\circ} \mathrm{C} ;[\alpha]_{\mathrm{D}}{ }^{24}=+41.0(c=$ 1.0, $\mathrm{CHCl}_{3}$ ). IR (film) 3408, 3064, 3032, 2865, 1454, 1400, 1364, 1249, 1097 , 1052, 1027, 996, 909, 732, $697 \mathrm{~cm}^{-1}$. ${ }^{1} \mathrm{H}$ NMR (500 MHz, $\left.\mathrm{CDCl}_{3}\right) \delta$ 7.57-7.53 (m, 3H, aromatics), 7.43-7.29 (m, 12H, aromatics), 5.50 (s, 1H, CH-benzylidene), 5.38 (s, 1H, H-1), 4.93-4.86 (m, 1H, $\left.\underline{\mathrm{H}}_{\underline{a}} \mathrm{H}_{\mathrm{b}} \mathrm{Bn}-2\right)$, 4.82-4.76 (m, 2H, Bn-3), 4.734.69 (m, 1H, $\left.\mathrm{CH}_{\mathrm{a}} \underline{\mathrm{H}_{\mathrm{b}}} \mathrm{Bn}-2\right), 4.24$ (d, $\left.J_{6 \mathrm{a}, 6 \mathrm{~b}}=12.5 \mathrm{~Hz}, 1 \mathrm{H}, \mathrm{H}-6 \mathrm{a}\right), 4.23$ (s, 1H, H-4), $4.07\left(\mathrm{dd}, J_{1,2}=3.4, J_{2,3}=9.7 \mathrm{~Hz}, 1 \mathrm{H}, \mathrm{H}-2\right), 4.03\left(\mathrm{~d}, J_{6 \mathrm{a}, 6 \mathrm{~b}}=12.5 \mathrm{~Hz}, 1 \mathrm{H}, \mathrm{H}-6 \mathrm{~b}\right)$, $3.98\left(\mathrm{dd}, J_{3,4}=3.4, J_{2,3}=9.7 \mathrm{~Hz}, 1 \mathrm{H}, \mathrm{H}-3\right), 3.88$ (s, 1H, H-5), 2.90 (s, 1H, 1-OH); ${ }^{13} \mathrm{C}$ NMR $\left(125 \mathrm{MHz}, \mathrm{CDCl}_{3}\right) \delta 138.5,138.2,137.8,128.9,128.7,128.6,128.5$, $128.45,128.39,128.21,128.18,128.14,128.1,128.9,128.8,128.7,126.3$ (aromatics), 101.1 (CH-benzylidene), 92.2 (C1), 75.73 (C2), 75.71 (C3), 74.3 
(C4), 73.9 ( $\left.\underline{\mathrm{CH}}_{2} \mathrm{Bn}-2\right), 71.8\left(\underline{\mathrm{CH}}_{2} \mathrm{Bn}-3\right), 69.5$ (C6), 62.8 (C5); HRMS (ESI) $\mathrm{m} / \mathrm{z}$ calcd. for $\left[\mathrm{C}_{27} \mathrm{H}_{28} \mathrm{O}_{6}+\mathrm{Na}\right]^{+}$: 471.1778 , obsd.: 471.1774 .

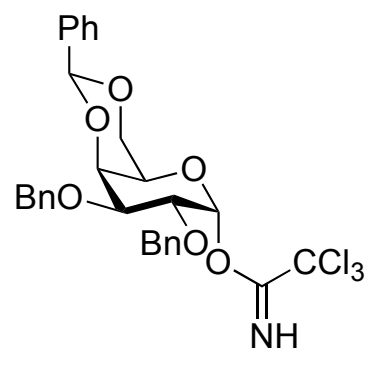

\section{2,3-di- $O$-benzyl-4,6- $O$-benzylidene- $\alpha$-D-galactosyl}

trichloroacetimidate (5). To a solution of lactol $13(370 \mathrm{mg}, 0.826 \mathrm{mmol}$, coevaporated $3 \mathrm{x}$ dry toluene) in dry DCM $(4 \mathrm{~mL})$ was added trichloroacetonitrile (826 $\mu \mathrm{L}, 1.19 \mathrm{~g}, 8.26 \mathrm{mmol})$ followed by 1,8-diazabicycloundec-7-ene (185 $\mu \mathrm{L}$, $1189 \mathrm{mg}, 1.24 \mathrm{mmol}$ ) and the resulting brown solution stirred $4 \mathrm{~h}$ at $\mathrm{rt}$. The solution was concentrated under reduced pressure and purified by gradient flash chromatography (Petroleum ether/EtOAc/NEt $3,95 / 5 / 1$ to $1 / 1 / 0, \mathrm{v} / \mathrm{v} / \mathrm{v}$ ) to give trichloroacetimidate 5 as a colourless oil $(81 \%, 394 \mathrm{mg}, 0.661 \mathrm{mmol}) . \mathrm{R}_{f}=0.69$ (Petroleum ether/EtOAc, $1 / 2, \mathrm{v} / \mathrm{v}) ; \mathrm{Mp}=140.8-142.1{ }^{\circ} \mathrm{C} ;[\alpha]_{\mathrm{D}}{ }^{24}=+93.0(c=$ 1.0, $\mathrm{CHCl}_{3}$ ). IR (film) 3339, 3065, 2907, 2864, 1671, 1497, 1456, 1368, 1290, 1249, 1175, 1120, 1098, 1027, 968, 846, 794, 738, $697 \mathrm{~cm}^{-1}$. ${ }^{1} \mathrm{H}$ NMR (500 MHz, $\left.\mathrm{CDCl}_{3}\right) \delta 8.58(\mathrm{~s}, 1 \mathrm{H}, \mathrm{H}-\mathrm{N}), 7.55-7.53(\mathrm{~m}, 3 \mathrm{H}$, aromatics), 7.40-7.28 (m, 15H, aromatics), $6.65\left(\mathrm{~d}, J_{1,2}=3.4 \mathrm{~Hz}, 1 \mathrm{H}, \mathrm{H}-1\right), 5.53$ (s, 1H, CH-benzylidene), 4.84 $\left(\mathrm{d}, J_{\mathrm{HaHb}}=11.9 \mathrm{~Hz}, 1 \mathrm{H}, \underline{\mathrm{C}}_{\underline{a}} \mathrm{H}_{\mathrm{b}} \mathrm{Bn}-3\right), 4.81\left(\mathrm{~d}, J_{\mathrm{HaHb}}=8.8 \mathrm{~Hz}, 1 \mathrm{H}, \underline{\mathrm{C}}_{\underline{a}} \mathrm{H}_{\mathrm{b}} \mathrm{Bn}-2\right)$, $4.79\left(\mathrm{~d}, J_{\mathrm{HaHb}}=8.8 \mathrm{~Hz}, 1 \mathrm{H}, \mathrm{CH}_{\mathrm{a}} \underline{\mathrm{H}}_{\mathrm{b}} \mathrm{Bn}-2\right), 4.77\left(\mathrm{~d}, J_{\mathrm{HaHb}}=11.9 \mathrm{~Hz}, 1 \mathrm{H}, \mathrm{CH}_{\mathrm{a}} \underline{\mathrm{H}}_{\mathrm{b}}\right.$ Bn-3), 4.31-4.27 (m, 3H, H-2, H-4 and H-6a), 4.09 (dd, $J_{3,4}=3.5, J_{2,3}=10.0 \mathrm{~Hz}$, $1 \mathrm{H}, \mathrm{H}-3), 4.02\left(\mathrm{dd}, J_{5,6 \mathrm{~b}}=1.5, J_{6 \mathrm{a}, 6 \mathrm{~b}}=12.7 \mathrm{~Hz}, 1 \mathrm{H}, \mathrm{H}-6 \mathrm{~b}\right), 3.85(\mathrm{~s}, 1 \mathrm{H}, \mathrm{H}-5) ;{ }^{13} \mathrm{C}$ $\operatorname{NMR}\left(125 \mathrm{MHz}, \mathrm{CDCl}_{3}\right) \delta 161.0(\underline{\mathrm{C}}=\mathrm{NH}), 138.4,138.3,137.6,129.0,128.3$, $128.26,128.2,128.0,127.7,127.5,127.4,126.4$ (aromatics), $101.1(\mathrm{CH}-$ benzylidene), 95.6 (C1), $91.4\left(\underline{\mathrm{CCl}}_{3}\right), 75.1$ (C2), 74.7 (C3), 74.5 (C4), 73.1 $\left(\underline{\mathrm{CH}}_{2} \mathrm{Bn}-2\right), 72.2\left(\underline{\mathrm{CH}}_{2} \mathrm{Bn}-3\right), 69.1$ (C6), 65.3 (C5). HRMS(ESI) $\mathrm{m} / \mathrm{z}$ calcd. for $\left[\mathrm{C}_{29} \mathrm{H}_{28} \mathrm{NO}_{6} \mathrm{Cl}_{3}+\mathrm{Na}\right]^{+}:$614.0874, obsd.: 614.0872. 


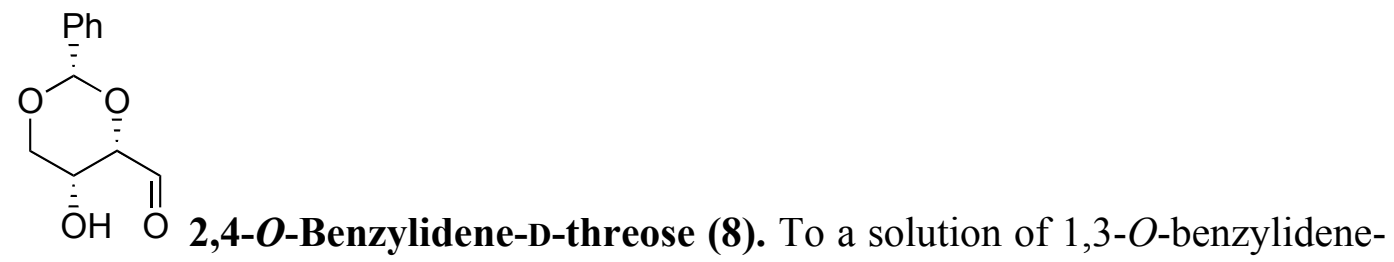
D-arabinitol $15^{7}$ (5.17 g, $\left.21.52 \mathrm{mmol}\right)$ in methanol $(100 \mathrm{~mL})$ was added $\mathrm{NaIO}_{4}$ $(5.07 \mathrm{~g}, 23.67 \mathrm{mmol})$ in water $(50 \mathrm{~mL})$. The reaction was stirred $20 \mathrm{~min}$ at $\mathrm{rt}$, at which point the reaction was deemed complete by TLC analysis $\left(\mathrm{R}_{f}=0.47\right.$, EtOAc). The solution was filtered, to remove the white precipitate, and concentrated under reduced pressure. The residue was dissolved in water $(50 \mathrm{~mL})$ and extracted four times with $100 \mathrm{~mL}$ EtOAc, dried over $\mathrm{MgSO}_{4}$, filtered and concentrated under reduced pressure. The resulting oil was co-evaporated three times with dry toluene and used immediately.<smiles>[Y10]CCP(Br)c1ccccc1</smiles>

Tetradecyltriphenylphosphoniumbromide (17). A solution of $\mathrm{PPh}_{3}(9.5 \mathrm{~g}, 36.0 \mathrm{mmol})$ in bromotetradecane $(10.75 \mathrm{~mL}, 10.0 \mathrm{~g}, 36.0 \mathrm{mmol})$ was heated to $140{ }^{\circ} \mathrm{C}$ under dry conditions, and stirred for $5 \mathrm{~h}$. The solution was cooled to approximately $40{ }^{\circ} \mathrm{C}$, and the product crystallised by the addition of 50 $\mathrm{mL}$ dry acetone followed by $120 \mathrm{~mL}$ dry diethyl ether to give phosphorane salt $\mathbf{1 7}$ as white crystals (14.98 g, $27.1 \mathrm{mmol}, 75 \%)$.<smiles>NC=CC1OC(c2ccccc2)OCC1O</smiles>

(2R,3R,4E)-1,3-O-Benzylidene-4-octadecen-1,2,3-triol (18). To a solution of $\mathrm{PhBr}(15.20 \mathrm{~g}, 96.85 \mathrm{mmol})$ in dry diethyl ether $(45 \mathrm{~mL})$ at $0{ }^{\circ} \mathrm{C}$ Li $(1.35 \mathrm{~g}, 195 \mathrm{mmol})$ was added in small pieces. The solution was stirred at $\mathrm{rt}$ until all Li metal dissolved ( 3 h). To phosphorane salt 17 (14.5 g, $26.9 \mathrm{mmol})$ in dry toluene $(210 \mathrm{~mL})$ under an atmosphere of nitrogen at $-30{ }^{\circ} \mathrm{C}$, the phenyllithium base was added via a cannula needle. The reaction mixture was stirred $30 \mathrm{~min}$ at $-30{ }^{\circ} \mathrm{C}$, before the addition of aldehyde $8(5.17 \mathrm{~g}, 21.5 \mathrm{mmol})$ in dry THF $(30 \mathrm{~mL})$. The reaction was stirred $1 \mathrm{~h}$ at $-30{ }^{\circ} \mathrm{C}$, then left to warm up slowly over night. After $18 \mathrm{~h}$ the reaction was quenched by the addition of methanol $(100 \mathrm{~mL})$ and water $(50 \mathrm{~mL})$ and stirred a further $1 \mathrm{~h}$. The layers were 
then separated, the organic layer was washed with brine $(200 \mathrm{~mL})$, dried over $\mathrm{MgSO}_{4}$, filtered, concentrated under reduced pressure. The resulting oil was purified by gradient flash chromatography (Petroleum ether/EtOAc, 100/0 to 10/1, $\mathrm{v} / \mathrm{v})$ to give 18 as a waxy solid. (4:1 mixture, $E: Z, 77 \%, 6.39 \mathrm{~g}, 16.5 \mathrm{mmol})$. The isomers could be separated at this stage using a long $(\sim 60 \mathrm{~cm})$ gradient flash column (DCM/Hexanes, 1/1 to 3/2, v/v). $\mathrm{R}_{f}=0.01$ (Petroleum ether/EtOAc, 9/1, $\mathrm{v} / \mathrm{v}) ;[\alpha]_{\mathrm{D}}^{21}=-12.0\left(c=0.4, \mathrm{CHCl}_{3}\right)$. IR (film) 3578, 3434, 3012, 2923, 2853, 1454, 1395, 1359, 1310, 1216, 1130, 1087, 1027, 887, 849, 813, 755, $698 \mathrm{~cm}^{-1}$. ${ }^{1} \mathrm{H}$ NMR (500 MHz, $\mathrm{CDCl}_{3}$ ) $\delta$ 7.54-7.51 (m, 2H, aromatics), 7.41-7.36 (m, 3H, aromatics), 5.88 (ddd, $\left.J_{3,5}=1.0, J_{5,6}=6.7, J_{4,5}=15.5 \mathrm{~Hz}, 1 \mathrm{H}, \mathrm{H}-5\right), 5.67$ (ddt, $J_{3,4}$ $\left.=6.2, J_{4,5}=15.5, J_{4,6 \mathrm{a}}=J_{4,6 \mathrm{~b}}=1.3 \mathrm{~Hz}, 1 \mathrm{H}, \mathrm{H}-4\right), 5.63$ (s, 1H, CH-benzylidene), $4.43\left(\mathrm{~d}, J_{3,4}=6.2 \mathrm{~Hz}, 1 \mathrm{H}, \mathrm{H}-3\right), 4.26\left(\mathrm{dd}, J_{1 \mathrm{a}, 2}=2.0, J_{1 \mathrm{a}, 1 \mathrm{~b}}=11.8 \mathrm{~Hz}, 1 \mathrm{H}, \mathrm{H}-1 \mathrm{a}\right)$ $4.10\left(\mathrm{dd}, J_{1 \mathrm{~b}, 2}=1.3, J_{1 \mathrm{a}, 1 \mathrm{~b}}=11.8 \mathrm{~Hz}, 1 \mathrm{H}, \mathrm{H}-1 \mathrm{~b}\right), 3.55\left(\mathrm{br}-\mathrm{d}, J_{2, \mathrm{OH}}=10.0 \mathrm{~Hz}, 1 \mathrm{H}\right.$, $\mathrm{H}-2), 2.65\left(\mathrm{~d}, J_{2, \mathrm{OH}}=10.0 \mathrm{~Hz}, 1 \mathrm{H}, 2-\mathrm{OH}\right), 2.09\left(\mathrm{ddd}, J_{4,6}=1.3, J_{5,6}=6.7, J_{6,7}=\right.$ 14.1 Hz, 2H, H-6a and H-6b), 1.39 (m, 2H, H-7), 1.27 (m, 20H, H-8 to H-17), 0.87 (t, $\left.J_{17,18}=7.0 \mathrm{~Hz}, 3 \mathrm{H}, \mathrm{H}-18\right) ;{ }^{13} \mathrm{C} \mathrm{NMR}\left(125 \mathrm{MHz}, \mathrm{CDCl}_{3}\right) \delta 137.9$ (C5), 135.3, 129.0, 128.3, 126.1, (aromatics), 125.9 (C4), 101.5 (benzylidene- $\underline{\mathrm{CH}}$ ), 80.7 (C3), 72.4 (C1), 66.4 (C2), 32.5 (C6), 31.9, 29.69, 29.68, 29.66, 29.6, 29.5, 29.4, 29.3, 29.0, 22.7 (C7 to C17), 14.1 (C18); HRMS(ESI) $\mathrm{m} / z$ calcd. for $\left[\mathrm{C}_{25} \mathrm{H}_{40} \mathrm{O}_{3}+\mathrm{Na}\right]^{+}: 411.2870$, obsd.: 411.2871 .<smiles>[Y10]CC=CC1OC(c2ccccc2)OCC1N=N</smiles>

11

(2S,3R,4E)-2-Azido-1,3-O-benzylidene-4-octadecen-1,3-diol

(19). To a solution of $\mathbf{1 8}(1.360 \mathrm{~g}, 3.51 \mathrm{mmol})$ (co-evaporated three times with dry toluene, $8 \mathrm{~mL})$ in freshly distilled DCM $(9.5 \mathrm{~mL})$ with dry pyridine $(707 \mu \mathrm{L}$, $8.76 \mathrm{mmol})$ at $-15{ }^{\circ} \mathrm{C}$ under nitrogen, $\mathrm{Tf}_{2} \mathrm{O}(737 \mu \mathrm{L}, 4.38 \mathrm{mmol})$ was added slowly drop wise over $30 \mathrm{~min}$. The solution was stirred an additional $15 \mathrm{~min}$ at $15^{\circ} \mathrm{C}$ before the slow addition (over $2 \mathrm{~min}$ ) of dry DMF $(35 \mathrm{~mL}) . \mathrm{NaN}_{3}(0.913 \mathrm{~g}$, $14.05 \mathrm{mmol}$ ) was then added in one portion and the reaction slowly warmed to room temperature and stirred for $5 \mathrm{~h}$, at which point TLC analysis deemed the reaction complete. The reaction was quenched with water $(100 \mathrm{~mL})$ and extracted 
with petroleum ether (three times $30 \mathrm{~mL}$ ). The organic layers were combined, washed brine $(100 \mathrm{~mL})$, dried over $\mathrm{MgSO}_{4}$, filtered and concentrated under reduced pressure. The resulting oil was purified by gradient flash chromatography (Petroleum ether/EtOAc, 100/1 to 50/1, v/v) to give $\mathbf{1 9}$ as a waxy solid (77\%, 1.11 g, $2.69 \mathrm{mmol}) . \mathrm{R}_{f}=0.39$ (Petroleum ether/EtOAc, 9/1, v/v); $[\alpha]_{\mathrm{D}}^{23}=-15.62(c=$ 1.0, $\mathrm{CHCl}_{3}$ ). IR (film) 3344, 2924, 2853, 2107, 1456, 1395, 1274, 1214, 1115, 1026, 970, 907, 731, $696 \mathrm{~cm}^{-1} .{ }^{1} \mathrm{H}$ NMR $\left(500 \mathrm{MHz}, \mathrm{CDCl}_{3}\right) \delta$ 7.49-7.46 (m, 2H, aromatics), 7.38-7.34 (m, 4H, aromatics), $5.99\left(\mathrm{dt}, J_{4,5}=15.4, J_{5,6 \mathrm{a}}=J_{5,6 \mathrm{~b}}=6.9\right.$ $\mathrm{Hz}, 1 \mathrm{H}, \mathrm{H}-5), 5.59$ (ddt, $\left.J_{3,4}=7.5, J_{4,5}=15.4, J_{4,6 \mathrm{a}}=J_{4,6 \mathrm{~b}}=1.2 \mathrm{~Hz}, 1 \mathrm{H}, \mathrm{H}-4\right), 5.50$ (s, 1H, CH-benzylidene), $4.35\left(\mathrm{dd}, J_{1 \mathrm{a}, 2}=5.2, J_{1 \mathrm{a}, 1 \mathrm{~b}}=10.8 \mathrm{~Hz}, 1 \mathrm{H}, \mathrm{H}-1 \mathrm{a}\right), 4.07$ $\left(\mathrm{dd}, J_{3,4}=7.5, J_{2,3}=9.4 \mathrm{~Hz}, 1 \mathrm{H}, \mathrm{H}-3\right), 3.63\left(\mathrm{t}, J_{1 \mathrm{a}, 1 \mathrm{~b}}=J_{1 \mathrm{~b}, 2}=10.8 \mathrm{~Hz}, 1 \mathrm{H}, \mathrm{H}-1 \mathrm{~b}\right)$, $3.48\left(\mathrm{ddd}, J_{1 \mathrm{a}, 2}=5.2, J_{2,3}=9.4, J_{1 \mathrm{~b}, 2}=10.8 \mathrm{~Hz}, 1 \mathrm{H}, \mathrm{H}-2\right), 2.12\left(\mathrm{ddd}, J_{4,6}=1.2, J_{5,6}\right.$ $=6.9, J_{6,7}=14.0 \mathrm{~Hz}, 2 \mathrm{H}, \mathrm{H}-6 \mathrm{a}$ and H-6b), $1.43(\mathrm{~m}, 2 \mathrm{H}, \mathrm{H}-7), 1.35-1.24(\mathrm{~m}$, $20 \mathrm{H}, \mathrm{H}-8$ to H-17), 0.89 (t, $\left.J_{17,18}=6.9 \mathrm{~Hz}, 3 \mathrm{H}, \mathrm{H}-18\right) ;{ }^{13} \mathrm{C}$ NMR (125 MHz, $\left.\mathrm{CDCl}_{3}\right) \delta 137.9$ (C5), 137.3, 129.1, 128.3, 126.2 (aromatics), 125.8 (C4), 101.1 (CH-benzylidene), 81.8 (C3), 69.1 (C1), 57.5 (C2), 32.5 (C7), 31.9, 29.68, 29.66, 29.59, 29.5, 29.4, 29.2, 28.7, 22.7 (C8 to C17), 14.1 (C18); HRMS(ESI) m/z calcd. for $\left[\mathrm{C}_{25} \mathrm{H}_{39} \mathrm{O}_{2} \mathrm{~N}_{3}+\mathrm{Na}\right]^{+}: 436.2934$, obsd.: 436.2932 .<smiles>[Y10]/C=C/C(=O)CCOC(O)c1ccccc1</smiles>

1-O-( $\alpha$-hydroxybenzylidene)-4-octadecen-3-one (21).

${ }^{1} \mathrm{H}$ NMR (500 MHz, $\left.\mathrm{CDCl}_{3}\right) \delta$ 7.42-7.23 (m, 5H, aromatics), 6.87 (dt, $J_{4,5}=16.0$, $\left.J_{5,6 \mathrm{a}}=J_{5,6 \mathrm{~b}}=6.7 \mathrm{~Hz}, 1 \mathrm{H}, \mathrm{H}-5\right), 6.16\left(\mathrm{dt}, J_{4,5}=16.0, J_{4,6 \mathrm{a}}=J_{4,6 \mathrm{~b}}=1.6,1 \mathrm{H} \mathrm{Hz}, \mathrm{H}-\right.$ 4), 5.47 (s, 1H, CH-benzylidene), $4.14\left(\mathrm{dt}, J_{1 \mathrm{a}, 1 \mathrm{~b}}=12.0, J_{1 \mathrm{a}, 2 \mathrm{a}}=J_{1 \mathrm{a}, 2 \mathrm{~b}}=6.7 \mathrm{~Hz}\right.$, $1 \mathrm{H}, \mathrm{H}-1 \mathrm{a}), 3.97\left(\mathrm{dt}, J_{1 \mathrm{a}, 1 \mathrm{~b}}=12.0, J_{1 \mathrm{~b}, 2 \mathrm{a}}=J_{1 \mathrm{~b}, 2 \mathrm{~b}}=6.7 \mathrm{~Hz}, 1 \mathrm{H}, \mathrm{H}-1 \mathrm{~b}\right), 2.91(\mathrm{~m}, 2 \mathrm{H}$, H-2a and H-2b), 2.22 (m, 2H, H-6a and H-6b), 1.41 (m, 2H, H-7), 1.27-1.18 (m, $20 \mathrm{H}, \mathrm{H}-8$ to H-17), 0.87 (t, $\left.J_{17 \mathrm{a}, 18}=J_{17 \mathrm{~b}, 18}=6.8 \mathrm{~Hz}, 3 \mathrm{H}, \mathrm{H}-18\right)$.<smiles>C[14CH2]/C=C/[C@H](O)CCO</smiles>

(2S,3R,4E)-2-Azido-4-octadecen-1,3-diol (22). To a solution of 19 (715 mg, $1.72 \mathrm{mmol})$ in DCM (4 mL), MeOH (19 mL), $\mathrm{H}_{2} \mathrm{O}$ (150 $\mu \mathrm{L})$, propane-1,3-diol (95 $\mu \mathrm{L}, 1.72 \mathrm{mmol})$, and $p \mathrm{TsOH}(\sim 75 \mathrm{mg})$ were added. The 
solution was stirred four days at rt then quenched using sat. aq. $\mathrm{NaHCO}_{3}$. The methanol was removed under reduced pressure, and the resulting bi-layer was diluted using EtOAc $(50 \mathrm{~mL})$ and washed sat. aq. $\mathrm{NaHCO}_{3}(50 \mathrm{~mL})$ and brine $(50$ $\mathrm{mL}$ ), dried over $\mathrm{MgSO}_{4}$, filtered, and concentrated under reduced pressure. The resulting oil was purified by gradient flash chromatography (Petroleum ether/EtOAc, 20/1 to $1 / 1, \mathrm{v} / \mathrm{v})$ to give 22 as a white solid $(90 \%, 505 \mathrm{mg}, 1.55$ mmol). $\mathrm{R}_{f}=0.43($ Petroleum ether/EtOAc, $1: 1, \mathrm{v} / \mathrm{v}) ;[\alpha]_{\mathrm{D}}{ }^{23}=-29.4(c=1.0$, $\mathrm{CHCl}_{3}$ ). IR (film) 3357, 2922, 2853, 2098, 1466, 1266, 1059, 1005, 971, 908, 735 $\mathrm{cm}^{-1} .{ }^{1} \mathrm{H}$ NMR $\left(500 \mathrm{MHz}, \mathrm{CDCl}_{3}\right) \delta 5.82\left(\mathrm{dt}, J_{4,5}=15.3, J_{5,6 \mathrm{a}}=J_{5,6 \mathrm{~b}}=6.7 \mathrm{~Hz}, 1 \mathrm{H}\right.$, $\mathrm{H}-5$ ), $5.53\left(\mathrm{ddt}, J_{3,4}=7.3, J_{4,5}=15.3, J_{4,6 \mathrm{a}}=J_{4,6 \mathrm{~b}}=1.4,1 \mathrm{H} \mathrm{Hz}, \mathrm{H}-4\right), 4.24$ (dd, $J_{2,3}$ $\left.=6.5, J_{3,4}=7.3 \mathrm{~Hz}, 1 \mathrm{H}, \mathrm{H}-2\right), 3.77(\mathrm{~m}, 2 \mathrm{H}, \mathrm{H}-1 \mathrm{a}$ and $\mathrm{H}-1 \mathrm{~b}), 3.50(\mathrm{~m}, 1 \mathrm{H}, \mathrm{H}-2)$, $2.06\left(\mathrm{ddd}, J_{4,6}=1.4, J_{5,6}=6.7, J_{6,7}=14.5 \mathrm{~Hz}, 2 \mathrm{H}, \mathrm{H}-6 \mathrm{a}\right.$ and H-6b), $1.38(\mathrm{~m}, 2 \mathrm{H}$, $\mathrm{H}-7$ ), 1.27 (m, 20H, H-8 to H-17), 0.87 (t, $J_{17 \mathrm{a}, 18}=J_{17 \mathrm{~b}, 18}=6.8 \mathrm{~Hz}, 3 \mathrm{H}, \mathrm{H}-18$ ); ${ }^{13} \mathrm{C}$ NMR (125 MHz, $\mathrm{CDCl}_{3}$ ) $\delta 136.1$ (C5), 128.0 (C4), 73.8 (C3), 66.7, (C2), 62.6 (C1), 32.3 (C6), 31.9, 29.70, 29.68, 29.67, 29.66, 29.60, 29.5, 29.4, 29.2, 28.9, 22.7 (C7 to C17), 14.1 (C18); $\mathrm{HRMS}(\mathrm{ESI}) \mathrm{m} / z$ calcd. for $\left[\mathrm{C}_{18} \mathrm{H}_{35} \mathrm{O}_{2} \mathrm{~N}_{3}+\mathrm{Na}\right]^{+}$: 348.2621, obsd.: 348.2624 .<smiles>C[Al]C=CC(O)C(C#N)CO</smiles>

(2S,3R,4E)-2-azido-1-O-trityl-4-octadecen-1,3-diol. To a solution of $22(653 \mathrm{mg}, 2.01 \mathrm{mmol})$, in pyridine $(10 \mathrm{~mL}), \operatorname{TrCl}(785 \mathrm{mg}, 2.82$ mmol) was added and the solution was stirred $48 \mathrm{~h}$ at $\mathrm{rt}$. The reaction mixture was then concentrated, and redissolved in diethyl ether $(30 \mathrm{~mL})$. The organic layer was washed with sat. aq. $\mathrm{NH}_{4} \mathrm{Cl}(30 \mathrm{~mL})$, sat. aq. $\mathrm{NaHCO}_{3}(30 \mathrm{~mL})$, and brine (30 $\mathrm{mL}$ ), dried over $\mathrm{MgSO}_{4}$, filtered and concentrated under reduced pressure. The resulting oil was purified by gradient flash chromatography (Petroleum ether/EtOAc, $100 / 0$ to $20 / 1, \mathrm{v} / \mathrm{v})$ to give $(2 S, 3 R, 4 E)$-2-azido-1-O-trityl-4octadecen-1,3-diol (97\%, $1.10 \mathrm{~g}, 1.95 \mathrm{mmol}) . \mathrm{R}_{f}=0.45$ (Petroleum ether/EtOAc, $3 / 3, \mathrm{v} / \mathrm{v}) ;[\alpha]_{\mathrm{D}}^{23}=-5.98\left(c=1.0, \mathrm{CHCl}_{3}\right)$. IR (film) 3374, 2729, 2810, 2096, 1597, $1415,1220,1047,858,746,668 \mathrm{~cm}^{-1} .{ }^{1} \mathrm{H}$ NMR $\left(500 \mathrm{MHz}, \mathrm{CDCl}_{3}\right) \delta$ 7.47-7.45 $\left(\mathrm{m}, 5 \mathrm{H}\right.$, aromatics), 7.34-7.24 $(\mathrm{m}, 10 \mathrm{H}$, aromatics $), 5.67\left(\mathrm{dtd}, J_{3,5}=0.9, J_{5,6 \mathrm{a}}=\right.$ $\left.J_{5,6 \mathrm{~b}}=6.6, J_{4,5}=15.4 \mathrm{~Hz}, 1 \mathrm{H}, \mathrm{H}-5\right), 5.34\left(\mathrm{ddt}, J_{3,4}=7.2, J_{4,5}=15.4, J_{4,6 \mathrm{a}}=J_{4,6 \mathrm{~b}}=\right.$ $1.4 \mathrm{~Hz}, 1 \mathrm{H}, \mathrm{H}-4), 4.21$ (ddd, $\left.J_{3,5}=0.9, J_{2,3}=5.4, J_{3,4}=7.2 \mathrm{~Hz}, 1 \mathrm{H}, \mathrm{H}-3\right), 3.53$ (t, 
$\left.J_{1,2}=J_{2,3}=5.4,1 \mathrm{H}, \mathrm{H}-2\right), 3.31\left(\mathrm{~d}, J_{1,2}=5.4 \mathrm{~Hz}, 2 \mathrm{H}, \mathrm{H}-1 \mathrm{a}\right.$ and $\left.\mathrm{H}-1 \mathrm{~b}\right), 1.96(\mathrm{~m}, 2 \mathrm{H}$, H-6). 1.32-1.25 (m, 22H, H-7 to H-17), 0.89 (t, $J_{17 \mathrm{a}, 18}=J_{17 \mathrm{~b}, 18}=6.9 \mathrm{~Hz}, 3 \mathrm{H}, \mathrm{H}-$ 18); ${ }^{13} \mathrm{C}$ NMR (125 MHz, $\left.\mathrm{CDCl}_{3}\right) \delta 143.5$ (C5), 135.4, 128.6, 127.9, 127.6, 127.2, 127.1 (aromatics and C4), 87.4 (Tr-C-OR), 73.1 (C3), 65.8 (C2), 63.4 (C1), 32.3, 31.9, 29.71, 29.69, 29.67, 29.60, 29.5, 29.4, 29.3, 29.2, 28.9, 22.7 (C6 to C17), 14.1 (C18); HRMS(ESI) $m / z$ calcd. for $\left[\mathrm{C}_{37} \mathrm{H}_{49} \mathrm{O}_{2} \mathrm{~N}_{3}+\mathrm{Na}\right]^{+}:$590.3717, obsd.: 590.3723 .

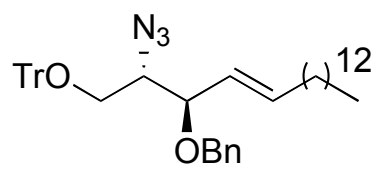

(2S,3R,4E)-2-azido-3-O-benzyl-1-O-trityl-4-octadecen-

1,3-diol. To a solution of $(2 S, 3 R, 4 E)$-2-azido-1- $O$-trityl-4-octadecen-1,3-diol $(1.10 \mathrm{~g}, 1.94 \mathrm{mmol})$ in dry $\mathrm{DMF}(11 \mathrm{~mL})$ at $0{ }^{\circ} \mathrm{C}$ was added $\mathrm{BnBr}(283 \mu \mathrm{L}, 407$ $\mathrm{mg}, 2.33 \mathrm{mmol}$ ) followed by $\mathrm{NaH}$ (as a 60\% mineral oil dispersion, $108 \mathrm{mg}, 2.53$ mmol). The resulting solution was warmed to rt and stirred overnight, excess $\mathrm{NaH}$ was quenched using $\mathrm{MeOH}$, and the solvent was removed under reduced pressure. The syrup was redissolved in diethyl ether $(50 \mathrm{~mL})$ and washed twice with water $(50 \mathrm{~mL})$ and brine $(50 \mathrm{~mL})$, dried over $\mathrm{MgSO}_{4}$, filtered and concentrated under reduced pressure. The resulting oil was purified by gradient flash chromatography (Petroleum ether/EtOAc, $20 / 1$ to $10 / 1, \mathrm{v} / \mathrm{v})$ to give $(2 S, 3 R, 4 E)-2$-azido-3-Obenzyl-1- $O$-trityl-4-octadecen-1,3-diol as a colourless oil $(95 \%, 1.21 \mathrm{~g}, 1.84$ mmol). $\mathrm{R}_{f}=0.46\left(\right.$ Petroleum ether/EtOAc, 5:1, v/v); $[\alpha]_{\mathrm{D}}^{23}=-12.0(c=1.0$, $\mathrm{CHCl}_{3}$ ). IR (film) 2924, 2853, 2097, 1490, 1449, 1066, 907, 731, 695, $617 \mathrm{~cm}^{-1}$. ${ }^{1} \mathrm{H}$ NMR (500 MHz, $\left.\mathrm{CDCl}_{3}\right) \delta 7.54-7.17$ (m, 20H, aromatics), 5.66 (dt, $J_{4,5}=$ $\left.15.4, J_{5,6 \mathrm{a}}=J_{5,6 \mathrm{~b}}=6.7 \mathrm{~Hz}, 1 \mathrm{H}, \mathrm{H}-5\right), 5.33\left(\mathrm{ddt}, J_{3,4}=8.5, J_{4,5}=15.4, J_{4,6 \mathrm{a}}=J_{4,6 \mathrm{~b}}=\right.$ $1.2 \mathrm{~Hz}, 1 \mathrm{H}, \mathrm{H}-4), 4.56\left(\mathrm{~d}, J_{\mathrm{Ha}, \mathrm{Hb}}=12.1 \mathrm{~Hz}, 1 \mathrm{H}, \mathrm{C}_{\underline{a}} \mathrm{H}_{\mathrm{b}} \mathrm{Bn}-3\right), 4.29\left(\mathrm{~d}, J_{\mathrm{Ha}, \mathrm{Hb}}=\right.$ $\left.12.1 \mathrm{~Hz}, 1 \mathrm{H}, \mathrm{CH}_{\mathrm{a}} \underline{\mathrm{H}}_{\mathrm{b}} \mathrm{Bn}-3\right), 3.89$ (dd, $\left.J_{2,3}=5.9, J_{3,4}=8.5 \mathrm{~Hz}, 1 \mathrm{H}, \mathrm{H}-3\right), 3.61$ (ddd, $\left.J_{1 \mathrm{~b}, 2}=4.9, J_{2,3}=5.9, J_{1 \mathrm{a}, 2}=6.3 \mathrm{~Hz}, 1 \mathrm{H}, \mathrm{H}-2\right), 3.28\left(\mathrm{dd}, J_{1 \mathrm{a}, 2}=6.3, J_{1 \mathrm{a}, 1 \mathrm{~b}}=9.6 \mathrm{~Hz}\right.$, $1 \mathrm{H}, \mathrm{H}-1 \mathrm{a}), 3.24\left(\mathrm{dd}, J_{1 \mathrm{~b}, 2}=4.9, J_{1 \mathrm{a}, 1 \mathrm{~b}}=9.6 \mathrm{~Hz}, 1 \mathrm{H}, \mathrm{H}-1 \mathrm{~b}\right), 2.04\left(\mathrm{ddd}, J_{4,6}=1.2\right.$, $J_{5,6}=6.7, J_{6 \mathrm{a}, 6 \mathrm{~b}}=14.3 \mathrm{~Hz}, 2 \mathrm{H}, \mathrm{H}-6 \mathrm{a}$ and H-6b) 1.35-1.27 (m, 22H, H-7 to H-17), $0.89\left(\mathrm{t}, J_{17 \mathrm{a}, 18}=J_{17 \mathrm{~b}, 18}=7.0 \mathrm{~Hz}, 3 \mathrm{H}, \mathrm{H}-18\right) ;{ }^{13} \mathrm{C} \mathrm{NMR}\left(125 \mathrm{MHz}, \mathrm{CDCl}_{3}\right) \delta 143.7$ (C5), 138.1, 137.9, 128.73, 128.66, 128.3, 127.8, 127.52, 127.46, 127.4, 127.08, 127.06, 127.0, (aromatics), 125.9 (C4), 87.0 (Tr-C-OR), 79.4 (C3), $77.3\left(\underline{\mathrm{CH}_{2}}\right.$ Bn), 65.0 (C2), 63.2 (C1), 32.3 (C6), 31.9, 29.72, 29.71, 29.68, 29.64, 29.5, 29.4, 
29.2, 29.0, 22.7 (C7 to C17), 14.1 (C18); HRMS(ESI) $\mathrm{m} / z$ calcd. for $\left[\mathrm{C}_{44} \mathrm{H}_{55} \mathrm{O}_{2} \mathrm{~N}_{3}+\mathrm{Na}\right]^{+}:$680.4186, obsd.: 680.4193 .

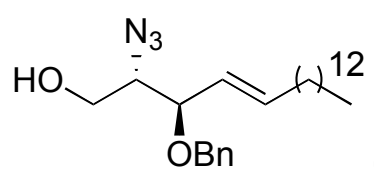

(2S,3R,4E)-2-Azido-3-O-benzyl-4-octadecen-1,3-diol (6).

To a solution of $(2 S, 3 R, 4 E)$-2-azido-3-O-benzyl-1- $O$-trityl-4-octadecen-1,3-diol $(1.18 \mathrm{~g}, 1.79 \mathrm{mmol})$ in DCM $(10 \mathrm{~mL})$ with triethylsilane $(569 \mu \mathrm{L}, 416 \mathrm{mg}, 3.58$ mmol) trifluoroacetic acid (TFA) was added slowly drop wise until the addition of TFA no longer turned the solution yellow. The mixture was then quenched using sat. aq. $\mathrm{NaHCO}_{3}$, and the organic layer further diluted using $20 \mathrm{~mL}$ DCM. The aqueous and organic layers were separated, and the organic layer was washed once more with sat. aq. $\mathrm{NaHCO}_{3}(30 \mathrm{~mL})$, followed by brine $(30 \mathrm{~mL})$, then dried over $\mathrm{MgSO}_{4}$, filtered and concentrated. The resulting oil was purified by gradient flash chromatography (Petroleum ether/EtOAc, 100/0 to 17/1, v/v) to give 6 as a colourless oil (78\%, $578 \mathrm{mg}, 1.39 \mathrm{mmol}$ ). $\mathrm{R}_{f}=0.58$ (Petroleum ether/EtOAc, 5/1, $\mathrm{v} / \mathrm{v}) ;[\alpha]_{\mathrm{D}}{ }^{20}=-66.8\left(c=1.0, \mathrm{CHCl}_{3}\right)$. IR (film) 3410, 3065, 2958, 2923, 2852, 2132, 2096, 1720, 1454, 1304, 1206, 1027, 973, 733, $697 \mathrm{~cm}^{-1} .{ }^{1} \mathrm{H}$ NMR (500 $\left.\mathrm{MHz}, \mathrm{CDCl}_{3}\right) \delta 7.37-7.28\left(\mathrm{~m}, 5 \mathrm{H}\right.$, aromatics), $5.79\left(\mathrm{dt}, J_{4,5}=15.5, J_{5,6 \mathrm{a}}=J_{5,6 \mathrm{~b}}=\right.$ $6.9 \mathrm{~Hz}, 1 \mathrm{H}, \mathrm{H}-5$ ), 5.44 (ddt, $J_{3,4}=8.4, J_{4,5}=15.5, J_{4,6 \mathrm{a}}=J_{4,6 \mathrm{~b}}=1.2 \mathrm{~Hz}, 1 \mathrm{H}, \mathrm{H}-4$ ), $4.63\left(\mathrm{~d}, J_{\mathrm{Ha}, \mathrm{Hb}}=11.9 \mathrm{~Hz}, 1 \mathrm{H}, \underline{\mathrm{C}}_{\underline{\mathrm{a}}} \mathrm{H}_{\mathrm{b}} \mathrm{Bn}\right), 4.36\left(\mathrm{~d}, J_{\mathrm{Ha}, \mathrm{Hb}}=11.9 \mathrm{~Hz}, 1 \mathrm{H}, \mathrm{CH}_{\mathrm{a}} \underline{\mathrm{H}}_{\mathrm{b}}\right.$ Bn), $3.90\left(\mathrm{dd}, J_{2,3}=6.1, J_{3,4}=8.4 \mathrm{~Hz}, 1 \mathrm{H}, \mathrm{H}-2\right), 3.73(\mathrm{~m}, 2 \mathrm{H}, \mathrm{H}-1 \mathrm{a}$ and $\mathrm{H}-1 \mathrm{~b})$, $3.51\left(\mathrm{ddd}, J_{1 \mathrm{a}, 2}=4.8, J_{2,3}=6.1, J_{1 \mathrm{~b}, 2}=10.5 \mathrm{~Hz}, 1 \mathrm{H}, \mathrm{H}-2\right), 2.11\left(\mathrm{ddd}, J_{4,6}=1.2, J_{5,6}\right.$ $=6.9, J_{6,7}=14.5 \mathrm{~Hz}, 2 \mathrm{H}, \mathrm{H}-6 \mathrm{a}$ and H-6b), 1.49 (m, 2H, H-7), 1.29 (m, 20H, H-8 to $\mathrm{H}-17), 0.88$ (t, $\left.J_{17 \mathrm{a}, 18}=J_{17 \mathrm{~b}, 18}=6.7 \mathrm{~Hz}, 3 \mathrm{H}, \mathrm{H}-18\right) ;{ }^{13} \mathrm{C} \mathrm{NMR}(125 \mathrm{MHz}$, $\left.\mathrm{CDCl}_{3}\right) \delta 138.4(\mathrm{C}-5), 137.8,128.5,127.8$ (aromatics), 126.1 (C4), 80.6 (C3), 70.0 (C1), 66.0 (C2), 62.7 ( $\left.\underline{\mathrm{CH}}_{2}-\mathrm{Ph}\right), 32.4$ (C6), 31.9, 29.70, 29.69, 29.68, 29.67, 29.63, 29.5, 29.4, 29.2, 29.0, 22.7 (C7 to C17), 14.1 (C18); HRMS(ESI) m/z calcd. for $\left[\mathrm{C}_{25} \mathrm{H}_{41} \mathrm{O}_{2} \mathrm{~N}_{3}+\mathrm{Na}\right]^{+}$: 438.3091 , obsd.: 438.3099 . 


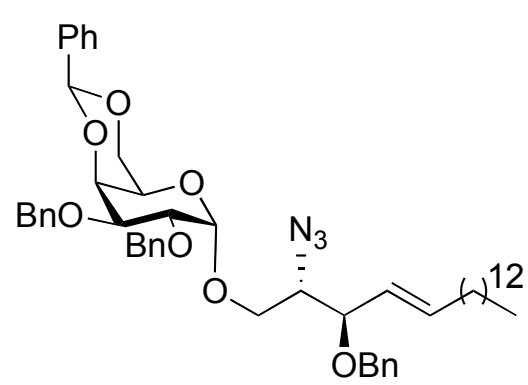

$(2 S, 3 R, 4 E)-2-A z i d o-3-O$-benzyl-1-O-(2,3-di-O-

benzyl-4,6- $O$-benzylidene- $\alpha$-D-galactopyranosyl)-4-octadecen-1,3-diol (23).

Lipid acceptor $6(65 \mathrm{mg}, 0.157 \mathrm{mmol})$ was co-evaporated three times with dry toluene $(3 \mathrm{~mL})$ together with imidate donor $5(158 \mathrm{mg}, 0.267 \mathrm{mmol})$. The mixture was dissolved in dry THF $(0.8 \mathrm{~mL})$, and cooled to $-20{ }^{\circ} \mathrm{C}$. Freshly distilled $\mathrm{BF}_{3} . \mathrm{OEt}_{2}(40 \mu \mathrm{L}, 23 \mathrm{mg}, 0.157 \mathrm{mmol})$ was then added slowly drop wise, and the resulting solution was stirred at $-20{ }^{\circ} \mathrm{C}$ for $2 \mathrm{~h}$, at which point additional donor 5 (78 $\mathrm{mg}, 0.131 \mathrm{mmol})$ in dry THF $(0.3 \mathrm{~mL})$ was added, and the solution was stirred an additional $2 \mathrm{~h}$ at $-20^{\circ} \mathrm{C}$. After this time the mixture was diluted with EtOAc $(15 \mathrm{~mL})$ and was washed sat. aq. $\mathrm{NaHCO}_{3}(15 \mathrm{~mL})$, and brine $(15 \mathrm{~mL})$, dried over $\mathrm{MgSO}_{4}$, filtered and concentrated under reduced pressure. The resulting oil was purified by gradient flash chromatography (Petroleum ether/EtOAc, 20/1 to 10/1, $\mathrm{v} / \mathrm{v})$ to give glycolipid 23 as a colourless oil $(65 \%, 87 \mathrm{mg}, 0.103 \mathrm{mmol}) . \mathrm{R}_{f}=0.46$ (Petroleum ether/EtOAc, 2/1, v/v, $) ;[\alpha]_{\mathrm{D}}{ }^{24}=+26.0\left(c=1.0, \mathrm{CHCl}_{3}\right)$. IR (film) 3065, 3032, 2925, 2853, 2096, 1737, 1496, 1400, 1340, 1245, 1154, 1049, 974, 907, 729, $696 \mathrm{~cm}^{-1} .{ }^{1} \mathrm{H}$ NMR (500 MHz, $\left.\mathrm{CDCl}_{3}\right) \delta$ 7.53-7.50 (m, 2H, aromatics), 7.42-7.23 (m, $18 \mathrm{H}$, aromatics), $5.71\left(\mathrm{dt}, J_{4,5}=15.5, J_{5,6 \mathrm{a}}=J_{5,6 \mathrm{~b}}=6.7 \mathrm{~Hz}, 1 \mathrm{H}, \mathrm{H}-\right.$ 5), 5.47 (s, 1H, CH-benzylidene), 5.41 (ddt, $J_{3,4}=8.5, J_{4,5}=15.5 \mathrm{~Hz}, 1 \mathrm{H}, \mathrm{H}-4$ ), $4.95\left(\mathrm{~d}, J_{1^{\prime}, 2^{\prime}}=3.4 \mathrm{~Hz}, 1 \mathrm{H}, \mathrm{H}-1^{\prime}\right), 4.86\left(\mathrm{~d}, J_{\mathrm{Ha}, \mathrm{Hb}}=12.0 \mathrm{~Hz}, 1 \mathrm{H}, \underline{\mathrm{H}}_{\mathrm{a}} \mathrm{H}_{\mathrm{b}} \mathrm{Bn}-2^{\prime}\right)$, $4.82\left(\mathrm{~d}, J_{\mathrm{Ha}, \mathrm{Hb}}=12.4 \mathrm{~Hz}, 1 \mathrm{H}, \underline{\mathrm{C}}_{\underline{a}} \mathrm{H}_{\mathrm{b}} \mathrm{Bn}-3\right.$ ') $4.74\left(\mathrm{~d}, J_{\mathrm{Ha}, \mathrm{Hb}}=12.4 \mathrm{~Hz}, 1 \mathrm{H}, \mathrm{CH}_{\mathrm{a}} \underline{\mathrm{H}}_{\underline{b}}\right.$ Bn-3'), $4.65\left(\mathrm{~d}, J_{\mathrm{Ha}, \mathrm{Hb}}=12.0 \mathrm{~Hz}, 1 \mathrm{H}, \mathrm{CH}_{\mathrm{a}} \underline{\mathrm{H}}_{\underline{b}} \mathrm{Bn}-2^{\prime}\right), 4.53\left(\mathrm{~d}, J_{\mathrm{Ha}, \mathrm{Hb}}=11.8 \mathrm{~Hz}\right.$, $\left.1 \mathrm{H}, \underline{\mathrm{C}}_{\mathrm{a}} \mathrm{H}_{\mathrm{b}} \mathrm{Bn}-3\right), 4.25\left(\mathrm{~d}, J_{\mathrm{Ha}, \mathrm{Hb}}=11.8 \mathrm{~Hz}, 1 \mathrm{H}, \mathrm{CH}_{\mathrm{a}} \underline{\mathrm{H}}_{\mathrm{b}} \mathrm{Bn}-3\right), 4.19$ (m, 2H, H-4' and H-6'a), 4.08 (dd, $\left.J_{1^{\prime}, 2^{\prime}}=3.4, J_{2^{\prime}, 3^{\prime}}=10.1 \mathrm{~Hz}, 1 \mathrm{H}, \mathrm{H}-2^{\prime}\right), 4.01$ (dd, $J_{3^{\prime}, 4^{\prime}}=3.4$, $J_{2}{ }^{\prime}, 3^{\prime}=10.1 \mathrm{~Hz}, 1 \mathrm{H}, \mathrm{H}-3^{\prime}$ ), 3.97 (m, 1H, H-6'b), 3.93 (dd, $J_{2,3}=6.3, J_{3,4}=8.5 \mathrm{~Hz}$, $1 \mathrm{H}, \mathrm{H}-3), 3.80\left(\mathrm{dd}, J_{1 \mathrm{a}, 2}=3.8, J_{1 \mathrm{a}, 1 \mathrm{~b}}=10.7 \mathrm{~Hz}, 1 \mathrm{H}, \mathrm{H}-1 \mathrm{a}\right), 3.66\left(\mathrm{dd}, J_{1 \mathrm{~b}, 2}=6.3\right.$, $\left.J_{1 \mathrm{a}, 1 \mathrm{~b}}=10.7 \mathrm{~Hz}, 1 \mathrm{H}, \mathrm{H}-1 \mathrm{~b}\right), 3.63$ (br s, $1 \mathrm{H}, \mathrm{H}-5$ '), 3.53 (dt, $J_{1 \mathrm{a}, 2}=3.8, J_{1 \mathrm{~b}, 2}=J_{2,3}=$ $6.3 \mathrm{~Hz}, 1 \mathrm{H}, \mathrm{H}-2), 2.10\left(\mathrm{dd}, J_{5,6}=6.7, J_{6,7}=14.6 \mathrm{~Hz}, 2 \mathrm{H}, \mathrm{H}-6\right), 1.41$ (m, 2H, H-7), 1.29 (m, 20H, H-8 to H-17), 0.88 (t, $\left.J_{17,18}=6.9 \mathrm{~Hz}, 3 \mathrm{H}, \mathrm{H}-18\right) ;{ }^{13} \mathrm{C}$ NMR $(125$ $\left.\mathrm{MHz}, \mathrm{CDCl}_{3}\right) \delta 138.9$ (C5), 138.2, 137.8, 128.9, 128.4, 128.29, 128.28, 128.1, 
127.74, 127.73, 127.6, 127.55, 127.52, 126.4 (aromatics), $126.2(\mathrm{C} 4), 101.1(\mathrm{CH}-$ benzylidene), 99.3 (C1'), 79.1 (C3), 75.8 (C3'), 75.5 (C2'), 74.7 (C5'), 73.5 ( $\left.\underline{\mathrm{CH}}_{2} \mathrm{Bn}-2^{\prime}\right), 72.2$ ( $\underline{\mathrm{CH}}_{2} \mathrm{Bn}-3$ '), 70.0 ( $\left.\underline{\mathrm{CH}}_{2} \mathrm{Bn}-3\right), 69.4$ (C6'), 68.2 (C1), 64.1 (C2), 63.0 (C4'), 32.4 (C6), 31.9, 29.71, 29.67, 29.5, 29.4, 29.2, 29.1, 22.7 (C7 to C17), 14.1 (C18); HRMS(ESI) $m / z$ calcd. For $\left[\mathrm{C}_{52} \mathrm{H}_{67} \mathrm{O}_{7} \mathrm{~N}_{3}+\mathrm{Na}\right]^{+}:$868.4871, obsd.: 868.4873 .

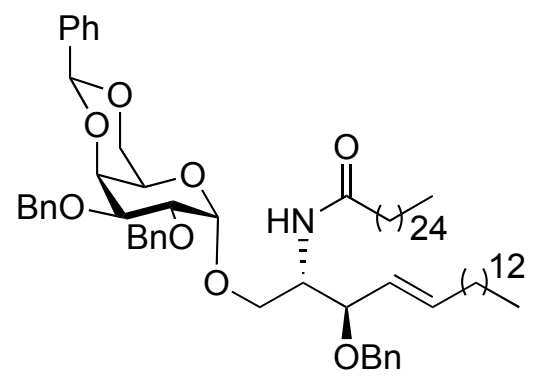

(2S,3R,4E)-3-O-Benzyl-1-O-(2,3-di-O-benzyl-

4,6-O-benzylidene- $\alpha$-D-galactopyranosyl)-2-hexacosylamido-4-octadecen-1,3-

diol (4). To a solution of azide 23 (86 mg, $0.102 \mathrm{mmol})$ in THF (0.4 mL), $\mathrm{PMe}_{3}$ (1M in THF, $509 \mu \mathrm{L}, 0.509 \mathrm{mmol}$ ) followed by $\mathrm{NaOH}$ (1M aqueous, $0.4 \mathrm{~mL}$ ) was added and the resulting solution was stirred at $\mathrm{rt}$ overnight, then diluted with EtOAc $(15 \mathrm{~mL})$ and washed sat. aq. $\mathrm{NaHCO}_{3}(15 \mathrm{~mL})$ and brine $(15 \mathrm{~mL})$, dried over $\mathrm{MgSO}_{4}$, filtered and concentrated under reduced pressure. The resulting oil was used without further purification. $\mathrm{R}_{f}=0.31$ (Petroleum ether/EtOAc, 2:1, $\mathrm{v} / \mathrm{v})$; To $(2 S, 3 R, 4 E)$-2-amino-3-O-benzyloxy-1-O-(2,3-di-O-benzyloxy-4,6-Obenzylidene - $\alpha$-D-galactopyranosyl)-4-octadecene-1,3-diol (84 mg $0.102 \mathrm{mmol}$, co-evaporated three times with dry toluene, $3 \mathrm{~mL})$ in dry DCM $(0.5 \mathrm{~mL})$, hexacosanoic acid (101 mg, $0.255 \mathrm{mmol}$ ), was added followed by EDCI (49 mg, $0.255 \mathrm{mmol}$ ), and a catalytic amount of DMAP. The reaction mixture was stirred overnight at $\mathrm{rt}$, then concentrated under reduced pressure. The resulting oil was purified by gradient flash chromatography (Petroleum ether/EtOAc, 10/1 to 2/1, $\mathrm{v} / \mathrm{v}$ ) to give 4 as a colourless oil ( $83 \%$ over the two steps, $101 \mathrm{mg}, 0.0844 \mathrm{mmol}$ ). $\mathrm{R}_{f}=0.44($ Petroleum ether/EtOAc, $2: 1, \mathrm{v} / \mathrm{v}) ;[\alpha]_{\mathrm{D}}{ }^{20}=+37.5\left(c=1.0, \mathrm{CHCl}_{3}\right)$. IR (film) 3298, 3032, 2956, 2918, 2850, 1641, 1542, 1468, 1453, 1343, 1159, 1099, 1054, $696 \mathrm{~cm}^{-1} .{ }^{1} \mathrm{H}$ NMR (500 MHz, $\left.\mathrm{CDCl}_{3}\right) \delta$ 7.53-7.51 (m, 2H, aromatics), 7.42-7.24 (m, 18H, aromatics), $5.82\left(\mathrm{br} \mathrm{d}, J_{2, \mathrm{NH}}=9.1 \mathrm{~Hz}, 1 \mathrm{H}, \mathrm{N}-\mathrm{H}\right), 5.59\left(\mathrm{dt}, J_{4,5}\right.$ $\left.=15.3, J_{5,6 \mathrm{a}}=J_{5,6 \mathrm{~b}}=6.8 \mathrm{~Hz}, 1 \mathrm{H}, \mathrm{H}-5\right), 5.46$ (s, 1H, CH-benzylidene), 5.34 (ddt, $\left.J_{3,4}=8.3, J_{4,5}=15.3, J_{4,6 \mathrm{a}}=J_{4,6 \mathrm{~b}}=1.3, \mathrm{~Hz}, 1 \mathrm{H}, \mathrm{H}-4\right), 4.92\left(\mathrm{~d}, J_{1^{\prime}, 2^{\prime}}=3.5 \mathrm{~Hz}, 1 \mathrm{H}\right.$, 
H-1'), $4.83\left(\mathrm{~d}, J_{\mathrm{Ha}, \mathrm{Hb}}=11.5 \mathrm{~Hz}, 1 \mathrm{H}, \underline{\mathrm{C}}_{\mathrm{a}} \mathrm{H}_{\mathrm{b}} \mathrm{Bn}-2^{\prime}\right), 4.78\left(\mathrm{~d}, J_{\mathrm{Ha}, \mathrm{Hb}}=12.2 \mathrm{~Hz}, 1 \mathrm{H}\right.$, $\mathrm{C}_{\underline{\mathrm{H}}} \mathrm{H}_{\mathrm{b}} \mathrm{Bn}-3^{\prime}$ ), $4.74\left(\mathrm{~d}, J_{\mathrm{Ha}, \mathrm{Hb}}=12.2 \mathrm{~Hz}, 1 \mathrm{H}, \mathrm{CH}_{\mathrm{a}} \underline{\mathrm{H}}_{\underline{b}} \mathrm{Bn}-3\right.$ '), 4.59 (d, $J_{\mathrm{Ha}, \mathrm{Hb}}=11.5$ $\left.\mathrm{Hz}, 1 \mathrm{H}, \mathrm{CH}_{\mathrm{a}} \underline{\mathrm{H}}_{\underline{b}} \mathrm{Bn}-2^{\prime}\right), 4.54\left(\mathrm{~d}, J_{\mathrm{Ha}, \mathrm{Hb}}=11.8 \mathrm{~Hz}, 1 \mathrm{H}, \underline{\mathrm{C}}_{\underline{a}} \mathrm{H}_{\mathrm{b}} \mathrm{Bn}-3\right), 4.23\left(\mathrm{~d}, J_{\mathrm{Ha}, \mathrm{Hb}}\right.$ $\left.=11.8 \mathrm{~Hz}, 1 \mathrm{H}, \mathrm{CH}_{\mathrm{a}} \underline{\mathrm{H}}_{\underline{\mathrm{b}}} \mathrm{Bn}-3\right), 4.17$ (m, 3H, H-2, H-4' and H-6'a), 4.04 (dd, $J_{1^{\prime}, 2^{\prime}}=$ $3.5, J_{2}{ }^{\prime}, 3^{\prime}=10.0 \mathrm{~Hz}, 1 \mathrm{H}, \mathrm{H}-2$ ') 3.94 (m, 2H, H-3' and H-6'b), 3.90 (dd, $J_{1 \mathrm{a}, 2}=5.5$, $\left.J_{1 \mathrm{a}, 1 \mathrm{~b}}=11.1 \mathrm{~Hz}, 1 \mathrm{H}, \mathrm{H}-1 \mathrm{a}\right), 3.83\left(\mathrm{dd}, J_{2,3}=6.7, J_{3,4}=8.3 \mathrm{~Hz}, 1 \mathrm{H}, \mathrm{H}-3\right), 3.75(\mathrm{dd}$, $\left.J_{1 \mathrm{~b}, 2}=3.8, J_{1 \mathrm{a}, 1 \mathrm{~b}}=11.1 \mathrm{~Hz}, 1 \mathrm{H}, \mathrm{H}-1 \mathrm{~b}\right), 3.57$ (br s, 1H, H-5'), 2.00 (m, 4H, H-6 and H- $\alpha$ ), 1.67 (m, 2H, H-7), 1.52 (m, 2H, H- $\beta$ ), 1.25 (m, 64H, H-8 to H-17, H- $\gamma$ to $\mathrm{H}-(\omega-1)), 0.88$ (t, $J_{17,18}=J_{\omega-1, \omega}=6.8 \mathrm{~Hz}, 6 \mathrm{H}, \mathrm{H}-18$ and $\left.\mathrm{H}-\omega\right) ;{ }^{13} \mathrm{C}$ NMR $(125$ $\mathrm{MHz}, \mathrm{CDCl}_{3}$ ) $\delta 172.6$ (C-carbonyl), 138.7 (C-5), 138.6, 138.4, 137.8, 137.1, $128.9,128.4,128.34,128.32,128.1,127.9,127.8,127.74,127.69,127.62,127.60$, 127.1, 126.3 (C-aromatics and C-4), 101.0 (CH-benzylidene), 99.6 (C-1'), 79.6 (C-3), 76.0 (C-3'), 75.7 (C-2'), 74.4 (C-4'), 73.7 ( $\left.\underline{\mathrm{C}}_{2} \mathrm{Bn}-2^{\prime}\right), 71.7$ ( $\left.\underline{\mathrm{CH}}_{2} \mathrm{Bn}-3^{\prime}\right)$,

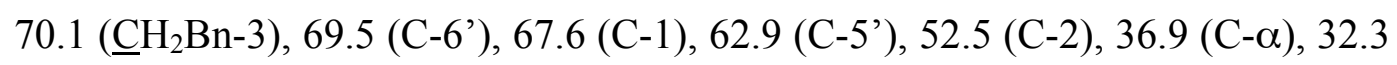
(C-6), 31.9, 29.74, 29.72, 29.70, 29.69, 29.67, 29.63, 29.55, 29.51, 29.4, 29.30, 29.28, 25.8, 22.7. (C-7 to $\mathrm{C}-17$ and $\mathrm{C}-\beta$ to $\mathrm{C}-(\omega-1)), 14.1$ (C-18 and $\mathrm{C}-\omega)$; HRMS(ESI) $m / z$ calcd. for $\left[\mathrm{C}_{78} \mathrm{H}_{119} \mathrm{O}_{8} \mathrm{~N}+\mathrm{Na}\right]^{+}: 1220.8828$, obsd.: 1220.8823 .

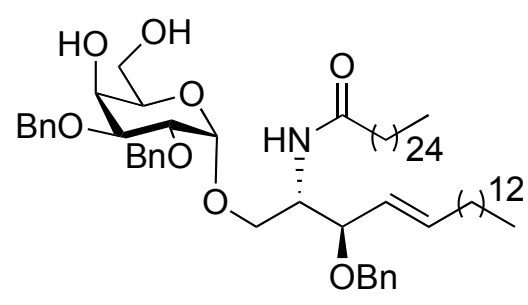

(2S,3R,4E)-3-O-Benzyl-1-O-(2,3-di- $O$-benzyl- $\alpha-$ D-galactopyranosyl)-2-hexacosylamido-4-octadecen-1,3-diol (24). A solution of fully protected glycolipid 4 (68 $\mathrm{mg}, 0.056 \mathrm{mmol})$ in $4: 1$ acetic acid/ $\mathrm{H}_{2} \mathrm{O}(2.5$ $\mathrm{mL})$ and THF ( $1 \mathrm{~mL})$ was heated to $75^{\circ} \mathrm{C}$ and stirred $24 \mathrm{~h}$, the mixture was then cooled and concentrated under reduced pressure. The resulting oil was purified by gradient flash chromatography (Petroleum ether/EtOAc, $5 / 1$ to $0 / 100, \mathrm{v} / \mathrm{v}$ ) to give 24 as a colourless oil $(100 \%, 64 \mathrm{mg}, 0.56 \mathrm{mmol}) . \mathrm{R}_{f}=0.32$ (Petroleum ether/EtOAc, $1 / 1, \mathrm{v} / \mathrm{v}) ;[\alpha]_{\mathrm{D}}{ }^{18}=-18.9\left(c=1.0, \mathrm{CHCl}_{3}\right)$. IR (film) 3395, 3303, 2919, 2850, 1740, 1641, 1539, 1469, 1346, 1216, 1157, 1049, 762, $695 \mathrm{~cm}^{-1} .{ }^{1} \mathrm{H}$ $\mathrm{NMR}\left(500 \mathrm{MHz}, \mathrm{CDCl}_{3}\right) \delta$ 7.37-7.25 (m, 15H, aromatics), 5.90 (br d, $J_{2, \mathrm{NH}}=9.5$ $\mathrm{Hz}, 1 \mathrm{H}, \mathrm{N}-\mathrm{H}), 5.65$ (dt, $\left.J_{4,5}=15.4, J_{5,6 \mathrm{a}}=J_{5,6 \mathrm{~b}}=6.8 \mathrm{~Hz}, 1 \mathrm{H}, \mathrm{H}-5\right), 5.37$ (ddt, $J_{3,4}$ 
$\left.=8.1, J_{4,5}=15.4, J_{4,6 \mathrm{a}}=J_{4,6 \mathrm{~b}}=1.3, \mathrm{~Hz}, 1 \mathrm{H}, \mathrm{H}-4\right), 4.84\left(\mathrm{~d}, J_{1^{\prime}, 2^{\prime}}=3.0 \mathrm{~Hz}, 1 \mathrm{H}, \mathrm{H}-\right.$ $\left.1^{\prime}\right), 4.78\left(\mathrm{~d}, J_{\mathrm{Ha}, \mathrm{Hb}}=11.4 \mathrm{~Hz}, 1 \mathrm{H}, \mathrm{C}_{\underline{a}} \mathrm{H}_{\mathrm{b}} \mathrm{Bn}-2^{\prime}\right), 4.76\left(\mathrm{~d}, J_{\mathrm{Ha}, \mathrm{Hb}}=11.9 \mathrm{~Hz}, 1 \mathrm{H}\right.$, $\left.\mathrm{C}_{\underline{a}} \mathrm{H}_{\mathrm{b}} \mathrm{Bn}-3^{\prime}\right), 4.70$ (d, $J_{\mathrm{Ha}, \mathrm{Hb}}=11.4 \mathrm{~Hz}, 1 \mathrm{H}, \mathrm{CH}_{\mathrm{a}} \underline{\mathrm{H}}_{\underline{b}} \mathrm{Bn}-2$ '), 4.60 (d, $J_{\mathrm{Ha}, \mathrm{Hb}}=11.9$ $\left.\mathrm{Hz}, 1 \mathrm{H}, \mathrm{CH}_{\mathrm{a}} \underline{\mathrm{H}}_{\underline{b}} \mathrm{Bn}-3^{\prime}\right), 4.57$ (d, $\left.J_{\mathrm{Ha}, \mathrm{Hb}}=11.8 \mathrm{~Hz}, 1 \mathrm{H}, \underline{\mathrm{C}}_{\underline{a}} \mathrm{H}_{\mathrm{b}} \mathrm{Bn}-3\right), 4.24$ (d, $J_{\mathrm{Ha}, \mathrm{Hb}}$ $\left.=11.8 \mathrm{~Hz}, 1 \mathrm{H}, \mathrm{CH}_{\mathrm{a}} \underline{\mathrm{H}}_{\mathrm{b}} \mathrm{Bn}-3\right), 4.24(\mathrm{~m}, 1 \mathrm{H}, \mathrm{H}-2), 4.03\left(\mathrm{~d}, J_{3^{\prime}, 4^{\prime}}=2.3 \mathrm{~Hz}, 1 \mathrm{H}, \mathrm{H}-\right.$ 4'), 3.96 (dd, $\left.J_{1 \mathrm{a}, 2}=6.3, J_{1 \mathrm{a}, 1 \mathrm{~b}}=11.4 \mathrm{~Hz}, 1 \mathrm{H}, \mathrm{H}-1 \mathrm{a}\right), 3.83$ (m, 4H, H-3, H-2', H-3', and H-6'a), 3.73 (m, 3H, H-1b, H-5', and H-6'b), 2.04 (m, 4H, H-6 and H- $\alpha$ ), $1.52(\mathrm{~m}, 2 \mathrm{H}, \mathrm{H}-7), 1.36(\mathrm{~m}, 2 \mathrm{H}, \mathrm{H}-\beta), 1.28(\mathrm{~m}, 64 \mathrm{H}, \mathrm{H}-8$ to $\mathrm{H}-17, \mathrm{H}-\gamma$ to $\mathrm{H}-(\omega-$ 1)), $0.88\left(\mathrm{t}, J_{17,18}=J_{\omega-1, \omega}=6.8 \mathrm{~Hz}, 6 \mathrm{H}, \mathrm{H}-18\right.$ and $\left.\mathrm{H}-\omega\right) ;{ }^{13} \mathrm{C}$ NMR $(125 \mathrm{MHz}$, $\left.\mathrm{CDCl}_{3}\right) \delta 172.9$ (C-carbonyl), 138.4, 138.3, 138.0 (C-aromatics), 137.0 (C-5), 128.5, 128.42, 128.38, 128.0, 127.84, 127.76, 127.6, (C-aromatics), 126.8 (C-4), 99.4 (C-1'), 79.7 (C-3), 77.4 (C-2'), 75.8 (C-3’), $73.4\left(\underline{\mathrm{CH}}_{2} \mathrm{Bn}-3^{\prime}\right), 72.6\left(\mathrm{CH}_{2} \mathrm{Bn}\right.$ 2'), 70.1 ( $\left.\underline{\mathrm{CH}}_{2} \mathrm{Bn}-3\right), 69.6$ (C-5'), 68.7 (C-4'), 68.5 (C-1), 63.0 (C-6'), 52.6 (C-2), 36.9 (C- $\alpha$ ), 32.4 (C-6), 31.9, 29.74, 29.73, 29.71, 29.69, 29.68, 29.67, 29.59, 29.53, 29.46, 29.38, 29.37, 29.35, 29.30, 29.25, 25.7, 22.7 (C-7 to C-17 and C- $\beta$ to $\mathrm{C}-(\omega-1)), 14.1$ (C-18 and C- $\omega$ ); $\mathrm{HRMS}(\mathrm{ESI}) \mathrm{m} / \mathrm{z}$ calcd. for $\left[\mathrm{C}_{71} \mathrm{H}_{115} \mathrm{O}_{8} \mathrm{~N}_{3}+\mathrm{Na}\right]^{+}$: 1132.8515, obsd.: 1132.8513.

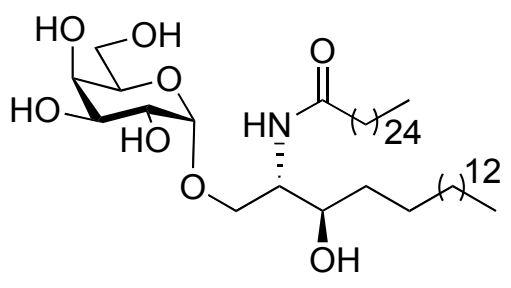

(2S,3R)-1-O-( $\alpha$-D-galactopyranosyl)-2-

hexacosylamidooctadecan-1,3-diol (2). To a solution of diol 24 (37 mg, 0.033 $\mathrm{mmol})$ in $\mathrm{EtOH} / \mathrm{DCM}(2 \mathrm{~mL}, 1 / 1, \mathrm{v} / \mathrm{v})$, was added $\mathrm{Pd}(\mathrm{OH})_{2}(0.5 \mathrm{mg}, 0.0033$ mmol), and $\mathrm{H}_{2}$. The mixture was stirred at $400 \mathrm{kPa}$ for $18 \mathrm{~h}$, at which point TLC analysis showed complete consumption of starting material. The reaction mixture was filtered through celite, and concentrated under reduced pressure. The resulting oil was purified by gradient flash chromatography (DCM/MeOH, 99/1 to $9 / 1, \mathrm{v} / \mathrm{v})$ to give target glycolipid 2 as an amorphous white solid $(100 \%, 28 \mathrm{mg}$, $0.033 \mathrm{mmol}) . \mathrm{R}_{f}=0.22(\mathrm{EtOAc} / \mathrm{MeOH}, 4 / 1, \mathrm{v} / \mathrm{v}) ;[\alpha]_{\mathrm{D}}{ }^{21}=+49.5(c=0.2$, pyridine). IR (film) 3352, 2917, 2850, 1734, 1717, 1699, 1636, 1558, 1507, 1466, $1033 \mathrm{~cm}^{-1} .{ }^{1} \mathrm{H}$ NMR (500 MHz, pyridine-d $\left.{ }_{6}\right) \delta 8.93$ (br d, $J_{2, \mathrm{NH}}=8.6 \mathrm{~Hz}, 1 \mathrm{H}, \mathrm{N}-$ H), $5.79\left(\mathrm{~d}, J_{1^{\prime}, 2^{\prime}}=3.7 \mathrm{~Hz}, 1 \mathrm{H}, \mathrm{H}-1^{\prime}\right), 5.07(\mathrm{~m}, 1 \mathrm{H}, \mathrm{H}-2), 4.99\left(\mathrm{dd}, J_{1^{\prime}, 2^{\prime}}\right.$ = 3.7, 
$\left.J_{2^{\prime}, 3^{\prime}}=9.9 \mathrm{~Hz}, 1 \mathrm{H}, \mathrm{H}-2^{\prime}\right), 4.05$ (d, $J_{3^{\prime}, 4^{\prime}}=3.3 \mathrm{~Hz}, 1 \mathrm{H}, \mathrm{H}-4^{\prime}$ ), 4.87 (t, $J_{5,6}=5.5 \mathrm{~Hz}$, 1H, H-5'), 4.82-4.79 (m, 2H, H-1a, and H-3'), 4.77-4.72 (m, 2H, H-6'a and H6’b), $4.69\left(\mathrm{dd}, J_{1 \mathrm{~b}, 2}=5.6, J_{1 \mathrm{a}, 1 \mathrm{~b}}=10.5 \mathrm{~Hz}, 1 \mathrm{H}, \mathrm{H}-1 \mathrm{~b}\right), 4.63-4.59$ (m, 1H, H-3), $2.81\left(\mathrm{t}, J_{\alpha, \beta}=7.3 \mathrm{~Hz}, 2 \mathrm{H}, \mathrm{H}-\alpha\right), 2.23-2.13(\mathrm{~m}, 4 \mathrm{H}, \mathrm{H}-4$ and $\mathrm{H}-\beta), 1.89-1.57$ (m, $70 \mathrm{H}, \mathrm{H}-5$ to $\mathrm{H}-17$ and $\mathrm{H}-\gamma$ to $\mathrm{H}-(\omega-1)), 1.20-1.16$ (m, $6 \mathrm{H}, \mathrm{H}-18$ and $\mathrm{H}-\omega) ;{ }^{13} \mathrm{C}$ NMR (125 MHz, pyridine-d 6 ) 173.6 (C-carbonyl), 102.2 (C-1'), 73.2 (C-5'), 72.0 (C-3), 71.7 (C-3'), 71.1 (C-4'), 70.6 (C-2'), 69.8 (C-1), 62.8 (C-6'), 55.0 (C2), $36.9(\mathrm{C}-\alpha)$, 35.2, 32.24, 32.23, 30.3, 30.2, 30.14, 30.13, 30.09, 30.05, 30.03, $29.95,29.86,29.74,29.71,26.7,26.5,23.1,23.0$ (C-4 to $\mathrm{C}-17$ and $\mathrm{C}-\beta$ to $\mathrm{C}-(\omega-$ 1)), 14.4 (C-18 and C- $\omega)$; HRMS(ESI) $m / z$ calcd. for $\left[\mathrm{C}_{50} \mathrm{H}_{99} \mathrm{O}_{8} \mathrm{~N}+\mathrm{Na}\right]^{+}$: 864.7263, obsd.: 864.7266 .

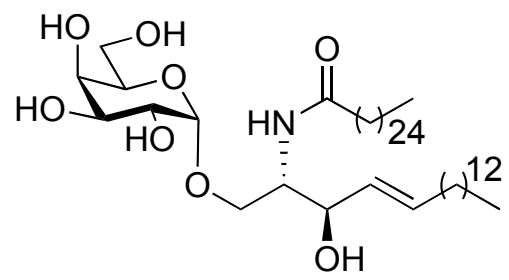

$(2 S, 3 R, 4 E)-1-O-(\alpha-D-g a l a c t o p y r a n o s y l)-2-$

hexacosylamido-4-octadecen-1,3-diol (3). To a solution of fully protected glycolipid 4 (11 mg, $0.00919 \mathrm{mmol}$ ) in $0.5 \mathrm{~mL}$ THF, $\mathrm{NH}_{3}$ (L) was added, followed by the careful addition of $\mathrm{Na}$ (s) until the blue colour remained. The solution was stirred for $1 \mathrm{~h}$ under refluxing $\mathrm{NH}_{3}$, then allowed to warm to $\mathrm{rt}$ and the excess $\mathrm{NH}_{3}$ was evaporated. The solution was neutralised by the addition of Dowex $\mathrm{H}^{+}$, filtered and concentrated under reduced pressure. The resulting powder was purified by gradient flash column chromatography (DCM/MeOH, $99 / 1$ to $9 / 1, v / v)$ to give sphingosine glycolipid 3 as an amorphous white solid (97\%, $7.5 \mathrm{mg}, 0.089 \mathrm{mmol}) . \mathrm{R}_{f}=0.16(\mathrm{EtOAc} / \mathrm{MeOH}, 9 / 1, \mathrm{v} / \mathrm{v}) ;[\alpha]_{\mathrm{D}}{ }^{21}=+42.5(c$ $=0.3$, pyridine). IR (film) 3348, 2948, 2837, 1653, 1450, 1412, 1217, 1113, 1016 $\mathrm{cm}^{-1} .{ }^{1} \mathrm{H} \mathrm{NMR}\left(500 \mathrm{MHz}, \mathrm{CDCl}_{3} / \mathrm{CD}_{3} \mathrm{OD}, 9 / 1, \mathrm{v} / \mathrm{v}\right) \delta 5.46\left(\mathrm{dt}, J_{4,5}=15.4, J_{5,6 \mathrm{a}}=\right.$ $\left.J_{5,6 \mathrm{~b}}=6.9 \mathrm{~Hz}, 1 \mathrm{H}, \mathrm{H}-5\right), 5.18\left(\mathrm{dd}, J_{3,4}=7.1, J_{4,5}=15.4 \mathrm{~Hz}, 1 \mathrm{H}, \mathrm{H}-4\right), 4.61(\mathrm{~d}$, $\left.J_{1^{\prime}, 2^{\prime}}=3.8 \mathrm{~Hz}, 1 \mathrm{H}, \mathrm{H}-1^{\prime}\right), 3.81$ (t, $\left.\mathrm{J}_{2,3}=J_{3,4}=7.1,1 \mathrm{H}, \mathrm{H}-3\right), 3.79-3.69$ (m, $1 \mathrm{H}$, H-2), 3.67 (m, 1H, H-4'), 3.54 - 3.46 (m, 7H, H-1a, H-1b, H-2', H-3', H-5', H6'a, and H-6'b), 1.92 (t, $\left.J_{\alpha, \beta}=7.8 \mathrm{~Hz}, 2 \mathrm{H}, \mathrm{H}-\alpha\right), 1.76\left(\mathrm{dd}, J_{5,6}=6.9, J_{6,7}=14.2\right.$ $\mathrm{Hz}, 2 \mathrm{H}, \mathrm{H}-6), 1.32$ (m, 2H, H- $\beta$ ), $1.11-1.00$ (m, 66H, H-7 to H-17, H- $\gamma$ to H-( $\omega-$ 1)), $0.62\left(\mathrm{t}, J_{17,18}=J_{\omega-1, \omega}=6.9 \mathrm{~Hz}, 6 \mathrm{H}, \mathrm{H}-18\right.$ and $\left.\mathrm{H}-\omega\right) ;{ }^{13} \mathrm{C}$ NMR $(125 \mathrm{MHz}$, 
$\mathrm{CDCl}_{3} / \mathrm{CD}_{3} \mathrm{OD}, 9 / 1$, v/v) $\delta 174.8$ (C-carbonyl), 134.1 (C-5), 129.2 (C-4), 99.8 (C1'), 72.0 (C-3), 70.7 (C-2', or C-3' or C-5'), 70.1 (C-2', or C-3' or C-5'), 69.4 (C4'), 69.0 (C-2', or C-3' or C-5'), 67.3 (C-1), 61.6 (C-6'), 53.7 (C-2), 36.3 (C- $\alpha$ ), 32.3 (C-6), 31.8, 29.59, 29.55, 29.47, 29.4, 29.2, 29.17, 25.9, 22.5 (C-7 to C-17 and $\mathrm{C}-\beta$ to $\mathrm{C}-(\omega-1)), 13.7$ (C-18 and $\mathrm{C}-\omega)$; HRMS(ESI) $m / z$ calcd. for $\left[\mathrm{C}_{50} \mathrm{H}_{97} \mathrm{O}_{8} \mathrm{~N}+\mathrm{Na}\right]^{+}:$862.7106, obsd.: 862.7109. 


\subsection{References}

(1) Brossay, L.; Naidenko, O.; Burdin, N.; Matsuda, J.; Sakai, T.; Kronenberg, M. J. Immunol. 1998, 161, 5124-5128.

(2) Lacône, V.; Hanault, J.; Pipelier, M.; Blot, V.; Lecourt, T.; Rocher, J.; Turcot-Dudois, A.-L.; Marionneau, S.; Douillard, J.-Y.; Clément, M.; Le Pendu, J.; Bonneville, M.; Micouin, L.; Dubreuil, D. J. Med. Chem. 2009, 52, 4960-4963.

(3) Sabò, L.; Li, Y.; Polt, R. Tetrahedron Lett. 1991, 32, 585-588.

(4) Morales-Serna, J. A.; Boutureira, O.; Díaz, Y.; Matheu, M. I.; Castillón, S. Carbohydr. Res. 2007, 342, 1595-1612.

(5) Plettenburg, O.; Bodmer-Narkevitch, V.; Wong, C.-H. J .Org. Chem. 2002, 67, 4559-4564.

(6) Zimmermann, P.; Schmidt, R. R. Liebigs Ann. Chem. 1988, 663-667.

(7) David, S.; Estramareix, B.; Fischer, J.-C.; Thérisod, M. J. Chem. Soc. Perkin Trans. 1 1982, 2131-2137.

(8) Lee, A.; Farrand, K. J.; Dickgreber, N.; Hayman, C. M.; Jürs, S.; Hermans, I. F.; Painter, G. F. Carbohydr. Res. 2006, 341, 2785-2798.

(9) Dinkelaar, J.; Witte, M. D.; van den Bos, L. J.; van der Marel, G. A. Carbohydr. Res. 2006, 341, 1723-1729.

(10) Motawia, M. S.; Marcussen, J.; Møller, B. L. J. Carbohydr. Chem. 1995, 14, 1279-1294.

(11) Schlosser, M.; Christmann, K.-F. Angew. Chem. Int. Edit. 1965, 4, 689690.

(12) Schlosser, M.; Christmann, K.-F. Angew. Chem. Int. Edit. 1966, 5, 126.

(13) Du, W.; Kulkarni, S. S.; Gervay-Hague, J. Chem. Comm. 2007, 23362338.

(14) Morita, M.; Motoki, K.; Akimoto, K.; Natori, T.; Sakai, T.; Sawa, E.; Yamaji, K.; Koezuka, Y.; Kobayashi, E.; Fukushima, H. J. Med. Chem. 1995, 38, 2176-2187. 



\section{Chapter 3: Biological Testing of $\alpha$-GalCer Analogues}

\subsection{Introduction}

There has been considerable interest in synthesising structural analogues of $\alpha$ GalCer (1, Figure 3.1) to understand which components are required for CD1d presentation and iNKT cell activation. ${ }^{1-3}$ In particular, it is important to understand which structural elements are required for human iNKT cell activation. To more fully understand the influence of the 4-hydroxyl on speciesspecific glycolipid activity, we investigated the ability of $\alpha$-GalCer analogues 2 and $\mathbf{3}$ to activate both murine and human iNKT cells.

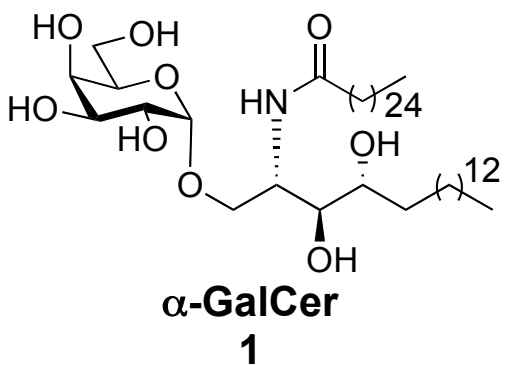

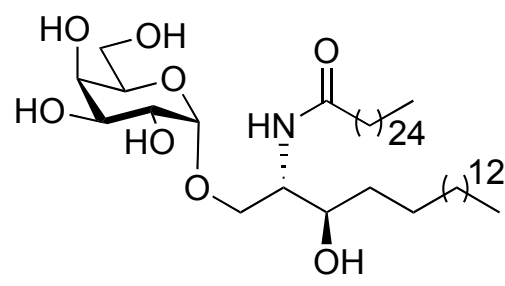

$\alpha$-GalCer analogue with sphinganine lipid 2

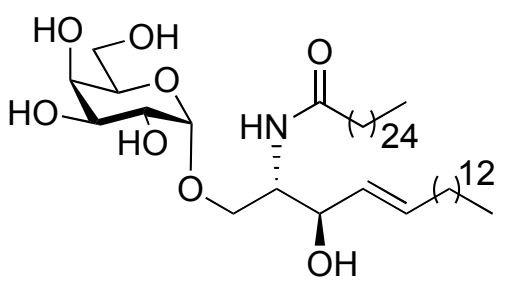

$\alpha$-GalCer analogue with sphingosine lipid 3

Figure 3.1. Glycolipids tested for their ability to activate iNKT cells. 


\subsection{Results}

To determine the ability of $\alpha$-GalCer analogues $\mathbf{2}$ and $\mathbf{3}$ to activate iNKT cells we investigated their in vivo activity in mice by measuring the expression of the costimulatory molecule CD86 on splenic DC and B cells and by assessing intracellular iNKT cell IL-4 and IFN- $\gamma$ cytokine levels in a similar manner to established literature protocols. ${ }^{4,5}$ The first assay is based on the observation that CD86 is upregulated in response to iNKT cell interaction with DC and B cells. Therefore CD86 expression is an indirect measure of iNKT cell activation. The ability of each glycolipid to activate murine or human iNKT cells in vitro was also determined by measuring iNKT cell proliferation as well as IL-2 and IFN- $\gamma$ cytokine production. These are well-established measures for determining iNKT cell glycolipid activity. ${ }^{6-9}$ iNKT cells secrete IL-2 and IFN- $\gamma$ in response to $\alpha$ GalCer activation. IL-2 mediates the differentiation and survival of cytotoxic T cells and IFN- $\gamma$ possesses anti-tumour properties, thus increased production of these cytokines is a good measure of potent anti-tumour iNKT cell activity.

To determine B cell and DC CD86 up-regulation mice were injected with $\alpha$ GalCer (1), sphinganine 2, or sphingosine $\mathbf{3}$ and sacrificed 1 day later. Splenocytes were isolated and the CD86 expression on B cells (B220 ${ }^{+}$) and DCs $\left(\mathrm{CD} 11 \mathrm{c}^{+}\right)$was measured using flow cytometry (Figure 3.2a). No significant difference in B cell or DC activation was observed between $\mathbf{1}$ and $\mathbf{2}$, however, a significant $(\mathrm{p}<0.05)$ decrease in both B cell and DC maturation was observed in response to glycolipid 3. To confirm the involvement of CD1d in this response, $\mathrm{CD}_{1} \mathrm{~d}^{-/-}$mice were injected with $\alpha$-GalCer (1), 2, or 3, and the CD86 expression on B cells and DCs was measured (Figure 3.2b). CD86 up-regulation was not observed in $\mathrm{CD} 1 \mathrm{~d}^{-/-}$mice, indicating that the immune response elicited involved CD1d. To more specifically assess the activity of the glycolipid analogues, intracellular iNKT cell cytokine levels were investigated in vivo. Mice were injected with $\alpha$-GalCer (1), 2, or $\mathbf{3}$, sacrificed $3 \mathrm{~h}$ later and the splenocytes removed. The levels of intracellular iNKT IL-4 and IFN- $\gamma$ were then determined using flow cytometric analysis (Figure 3.2c). All three analogues induced similar levels of IL-4. In contrast, sphingosine analogue $\mathbf{3}$ demonstrated a significant $(p<0.05)$ reduction in IFN- $\gamma$ production compared to both $\alpha-$ GalCer and 2. 

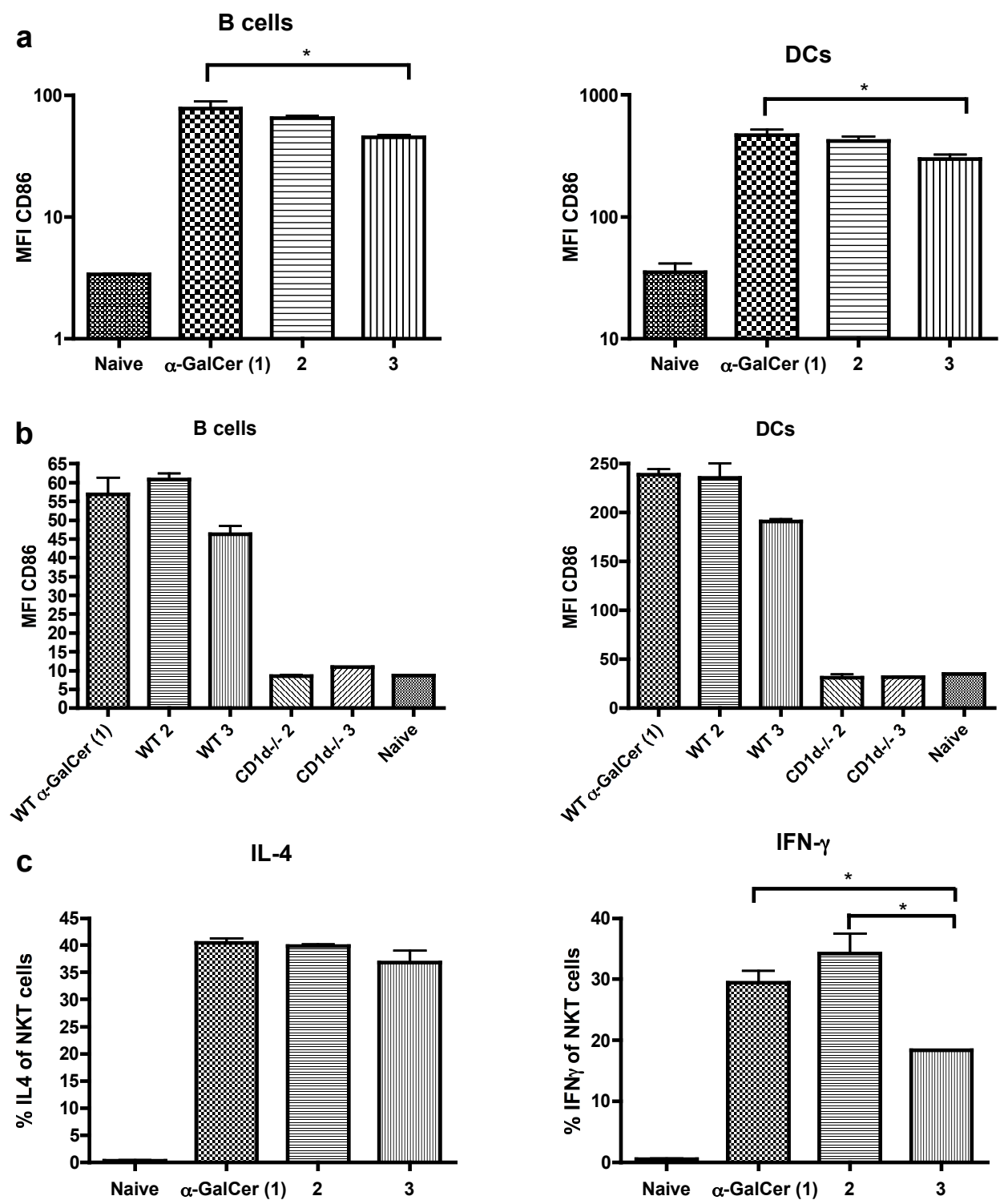

Figure 3.2. $\alpha$-GalCer analogues 2 and 3 are able to activate murine iNKT cells through CD1d presentation. a) C57BL/6 mice were injected intravenously with $200 \mathrm{ng}$ of $\mathbf{1}(n=3), \mathbf{2}(n=3)$ or $\mathbf{3}(n=3)$ and spleens were removed $20 \mathrm{~h}$ after injection for antibody labelling and flow cytometry. The expression of CD86 on $\mathrm{CD} 11 \mathrm{c}^{+}$dendritic cells and B220 $0^{+} \mathrm{B}$ cells was assessed. Mean fluorescence intensities (MFI) $\pm \mathrm{SD}$ are presented; b) $200 \mathrm{ng}$ of $\mathbf{1}(n=2), \mathbf{2}(n=2)$ or $\mathbf{3}(n=2)$ was injected into wild type $(\mathrm{C} 57 \mathrm{BL} / 6)$ and $\mathrm{CD}^{-/-}$mice, and spleens were removed $20 \mathrm{~h}$ after injection for antibody labelling and flow cytometry. The spleen of an untreated $\mathrm{CD}^{-/-}$mouse was used as a control. The expression of CD86 on $\mathrm{CD}_{11 \mathrm{c}^{+}}$dendritic cells and $\mathrm{B} 220^{+} \mathrm{B}$ cells was assessed. Mean fluorescence intensities (MFI) $\pm \mathrm{SD}$ are presented; c) C57BL/6 mice were injected with $200 \mathrm{ng}$ of $\mathbf{1}(n=2), \mathbf{2}(n=2)$ or $\mathbf{3}(n=2)$ and the spleens removed $3 \mathrm{~h}$ after injection for antibody labelling, formaldehyde fixing, and flow cytometry. The percent of intracellular IL-4 and IFN- $\gamma$ in tetramer positive iNKT cells was assessed using flow cytometry. 
Having demonstrated that the glycolipids activated murine iNKT cells through CD1d presentation, we then investigated their ability to stimulate human iNKT cells. Accordingly, human peripheral blood mononuclear cells (PBMCs), which include DCs, T cells, iNKT cells and B cells, were purified from whole blood. The healthy donor PBMCs were cultured for 7 days with decreasing concentrations of glycolipids $\mathbf{1}, \mathbf{2}$, or $\mathbf{3}$, or vehicle only. iNKT cell proliferation was measured using flow cytometric analysis (Figure 3.3). $\alpha$-GalCer induced iNKT cell expansion at concentrations as low as $24 \mathrm{pg} / \mathrm{mL}$. Analogues 2 and 3 were approximately 1,000 times less active, and iNKT cell proliferation was only initiated at glycolipid concentrations of $25 \mathrm{ng} / \mathrm{mL}$. This result suggested that analogues $\mathbf{2}$ and $\mathbf{3}$ were significantly less active in humans. However, this assay uses iNKT cell proliferation as a read out of iNKT cell activation. Therefore the result is not directly comparable to those obtained using the in vivo murine models (Figure 3.2). Accordingly, it was important to develop an assay that used the same read out for iNKT cell activation in both human and murine iNKT cells.

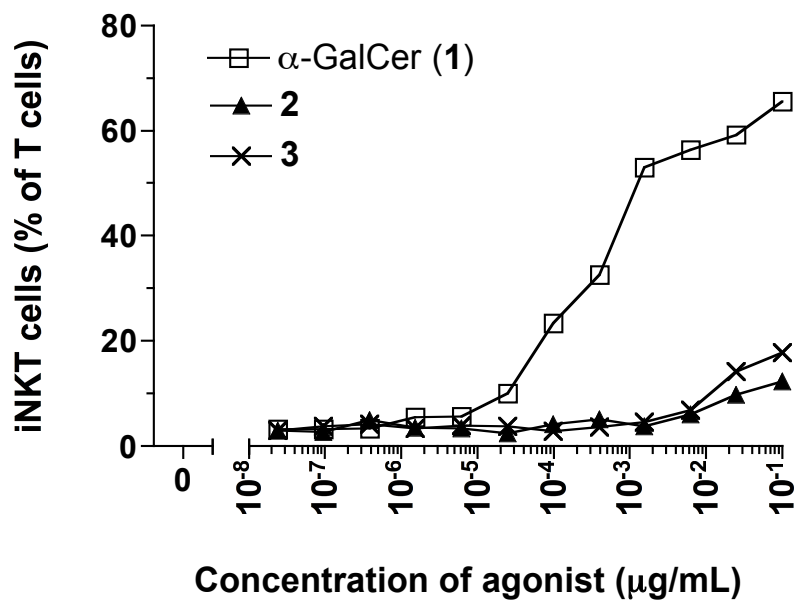

Figure 3.3. iNKT cell proliferation in whole PBMCs. 200,000 healthy donor PBMCs were cultured with titrated doses of either 1,2 or 3 in cIMDM $/ 5 \%$ human $\mathrm{AB}$ serum at $37{ }^{\circ} \mathrm{C}, 5 \% \mathrm{CO}_{2} .50 \mathrm{U} / \mathrm{mL}$ recombinant human IL-2 was added at 24 $\mathrm{h}$. The cells were harvested at day 7 for antibody labelling and flow cytometry. The number of $\mathrm{CD}^{+}, \mathrm{CD} 1 \mathrm{~d}$ tetramer ${ }^{+} \mathrm{CD} 19^{-}$iNKT cells was measured as a percentage of all live $\mathrm{CD}^{+}$cells (Rob Weinkove).

To more directly compare glycolipid activity across the two species we used human and murine in vitro DC-iNKT cell assays and measured the supernatant IL-2 and IFN- $\gamma$ levels. Mouse DCs (mDCs) and mouse iNKT (mNKT) cells were 
cultured together with decreasing concentrations of glycolipid 1, 2 or 3, and after $24 \mathrm{~h}$ the supernatant IL-2 and IFN- $\gamma$ levels were measured (Figure 3.4a). All glycolipids induced IL-2 and IFN- $\gamma$ production to similar extents suggesting that 2 and 3 had similar activity to $\alpha$-GalCer in mice. An analogous experiment was conducted using human DCs (hDCs) and human iNKT (hNKT) cells (Figure 3.4b). $\alpha$-GalCer (1) concentrations as low as $1 \mathrm{ng} / \mathrm{mL}$ induced IL-2 production, however, no activity was observed with either $\mathbf{2}$ or $\mathbf{3}$. This result paralleled the observations using human PBMCs (Figure 3.3) and supports the idea that the sphinganine and sphingosine $\alpha$-GalCer analogues ( 2 and 3 ) are less active in humans when compared to $\alpha$-GalCer. To further understand the mechanism behind the observed species-specific differences, we incubated hDCs with mNKT cell. This would enable us to clarify whether the difference in activity was due to insufficient human CD1d presentation, lack of human iNKT cell TCR recognition, or a combination of both. hDCs and $\mathrm{mNKT}$ cells were cultured together with glycolipids $\mathbf{1}, \mathbf{2}$ or $\mathbf{3}$, and the supernatant IL-2 and IFN- $\gamma$ levels measured (Figure 3.4c). In this system, similar levels of IL-2 and IFN- $\gamma$ were observed in response to each glycolipid. This indicates that $\mathrm{hDC}$ are able to present the glycolipid analogues and suggests that it is the hNKT cell TCR that is unable to recognise the CD1d-bound 4-deoxy $\alpha$-GalCer analogues. 

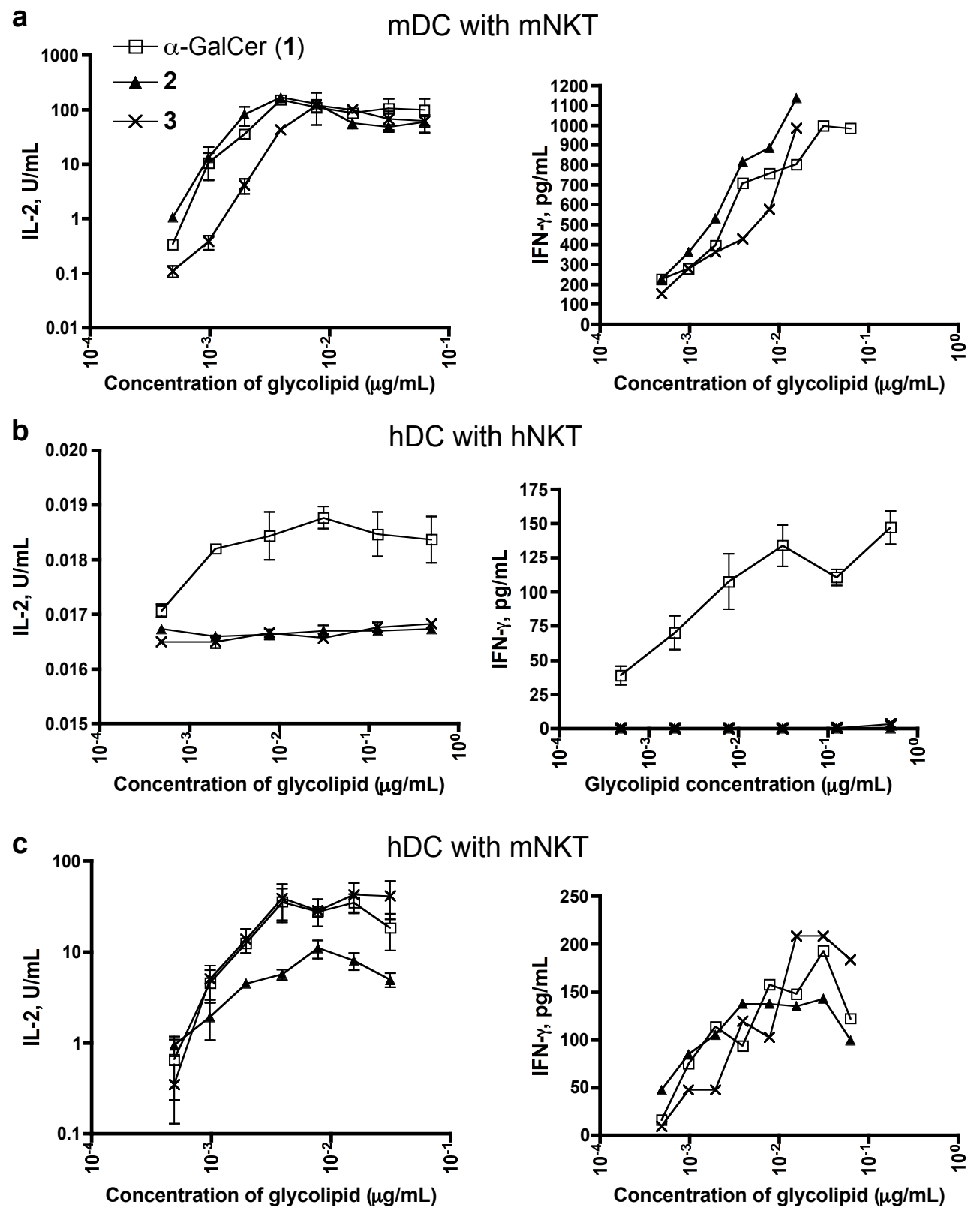

Figure 3.4. The human iNKT cell TCR is unable to recognise the 4-deoxy glycolipid analogues. a) Production of IL- 2 and IFN- $\gamma$ by the murine iNKT cells (DN32.D3) in the presence of titrated doses of $\mathbf{1}, \mathbf{2}$ or $\mathbf{3}$ presented by the murine DC cell line (DC2114); data representative of four individual experiments; error bars indicate SE of triplicate experiments; b) Production of IL-2 and IFN- $\gamma$ by human iNKT cells ( $V \alpha 24 V \beta 11$ clone) in the presence of titrated doses of $\mathbf{1 , 2}$ or $\mathbf{3}$ (in triplicate) presented by human PBMC derived DCs; data representative of two individual experiments; error bars indicate SE; c) Production of IL-2 and IFN- $\gamma$ by murine iNKT cells (DN32.D3) in the presence of titrated doses of $\mathbf{1}, \mathbf{2}$ or $\mathbf{3}$ presented by human PBMC derived DCs; error bars indicate SE of triplicate experiments. 


\subsection{Discussion}

In this work the 4-deoxy $\alpha$-GalCer analogues $\mathbf{2}$ and $\mathbf{3}$ possessed species-specific iNKT cell activities. We confirmed that glycolipids $\mathbf{1 ,} \mathbf{2}$ and $\mathbf{3}$ are similarly active in mice (Figure 3.2 and Figure 3.4a), this was consistent with literature findings. ${ }^{6,10,11}$ We also demonstrated that sphinganine 2 was at least 1,000 times less active toward human iNKT cells than $\alpha$-GalCer (1), highlighting the importance of the 4-hydroxyl for potent glycolipid activity in humans. To confirm this, we investigated the activity of sphingosine $\mathbf{3}$, which had not been previously tested. We found that the activity of $\mathbf{3}$ towards hNKT cells was 1,000 times less than that of 1. Again, this confirms the importance of the 4-OH for human iNKT cell activation and suggests that glycolipids developed for potent activity in humans should contain a ceramide base with the 4-hydroxyl present.

The observation that 4-deoxy glycolipids possess species-specific activities is consistent with the work by Kronenberg and co-workers, ${ }^{6}$ however is in opposition to the work by Dubreuil and co-workers. ${ }^{12}$ Dubreuil and co-workers found that glycolipids $\mathbf{1}$ and $\mathbf{2}$ induced comparable human iNKT cell activation and suggested that the species-specific activity observed by other groups was due to the removal of the 4-hydroxyl decreasing solubility and hence activity. In our work glycolipid solubility is unlikely to play a major role as no difference was observed in the same samples when tested in mice. Studies by Xia et al. also demonstrated the importance of the 4-hydroxyl for potent hNKT cell activation. In their work the phytosphingosine analogue of iGb3 (Chapter 1.2, Figure 13, pg 27) was synthesised and found to be 100 times more active than iGb3 itself. ${ }^{8}$ These results support our observations, and suggest that the 4-hydroxyl is critical for potent hNKT cell activation.

To elucidate the mechanism behind this species-specific activity we investigated human DC presentation to murine iNKT cells. We found that human DCs were able to present glycolipids 1, 2 and 3 almost equally well. This suggests that the reduced activity observed in the human system is not due to a lack of CD1d binding or DC presentation. In contrast, Kronenberg and co-workers attributed the decreased activity to insufficient human CD1d presenation. ${ }^{6}$ In their work mouse 
B cells were transfected with human CD1d. These cells were cultured together with mNKT cells and either glycolipid $\mathbf{1}$ or an analogue of $\mathbf{2}$ (where the acyl chain was C-24). In this assay IL-2 production was significantly reduced using the 4deoxy analogue, thus Kronenberg and co-workers suggested the species-specific activity was due to insufficient human CD1d presentation. However, as only one glycolipid concentration was investigated it is likely that this is exacerbating the relatively small difference we also observe in $\mathrm{hDC}$ presentation to $\mathrm{mNKT}$ cells (Figure 3.4c). We found that this difference was not as significant as that observed using $\mathrm{hDC}$ and hNKT cells. In addition, the reduced activity observed by Kronenberg and co-workers could also be due to the use of the C-24 acyl chain, as studies in the literature suggests that the C-26 acyl chain is the optimal length for iNKT cell activation. ${ }^{13}$

Our results suggest that structural differences in the iNKT cell TCR shape the species-specific activities of the 4-deoxy analogues. This is supported by recent studies in the literature, which suggest that changes to the TCR structure can alter glycolipid activity. In 2009, Joyce and co-workers demonstrated that a panel of murine iNKT cell hybridomas, each possessing different $\beta$-TCR-chains, produced varying amounts of IL-2, in response to stimulation by the same glycolipid. ${ }^{14}$ In addition, Tsuji and co-workers found that an E-alkene linked glycolipid was a more potent activator of human, rather than murine, iNKT cells. ${ }^{15}$ They determined that this preferential activity related to the binding affinity of the CD1d-glycolipid complex to the TCR and that differences in TCR structure were more important than differences in CD1d structure.

In view of this, it seems likely that the human and mouse TCR homologues respond differently to the 4-deoxy glycolipids. In an attempt to explain the reasons for these differences in more detail we compared the structural data available for human and mouse CD1d-glycolipid binding, and TCR recognition. This would enable us to identify the key amino acid residues involved in maintaining the ternary complex. Both human and murine CD1d proteins employ the Asp80 residue to bind to the 3- and 4-hydroxyls of the phytosphingosine lipid. ${ }^{16-19}$ Crystal structures demonstrate that the orientation of the Asp80 residue is very similar in the two CD1d homologues (Figure 3.5). ${ }^{18}$ In our studies, 
removing the 4-OH did not affect glycolipid binding to either human or mouse CD1d proteins as illustrated by mNKT cell cytokine production in response to both human and mouse DC presentation of 2 and 3 (Figure 3.4a and c). However, this chemical modification reduced the affinity of the human TCR for the CD1dglycolipid complex (Figure 3.4b).

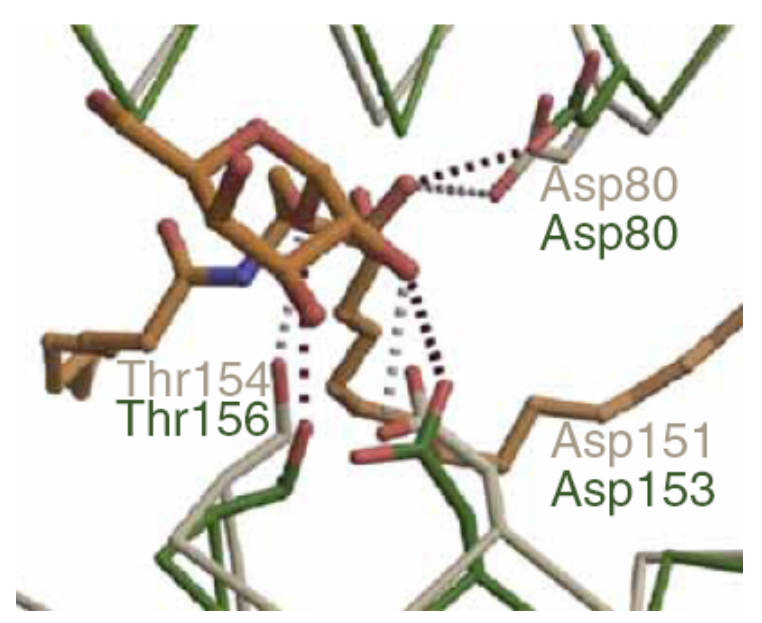

Figure 3.5. Structural alignment of the human (grey) and mouse (green) CD1d $\alpha-$ GalCer (orange) binding sites. The position and orientation of the Asp80 residue that binds to the 3- and 4-hydroxyls is conserved. (Image used with permission from the Nature Publishing Group) ${ }^{18}$

The prominent recognition force in the ternary complex (CD1d-glycolipid-TCR) is the H-bond network. ${ }^{16}$ The permanence of these interactions plays a vital role in the strength of the glycolipid response. In the human CD1d-glycolipid-TCR complex, one of the most important H-bonding interactions is between the Arg95 $\alpha$ residues in the alpha chain of the hTCR, to the Asp80 residue of the CD1d protein. ${ }^{16,18,20}$ The Arg95 $\alpha$ residue is in a different orientation in the mouse $\mathrm{TCR}^{21}$ and while it may still be involved in the TCR-glycolipid-CD1d binding complex, it is likely to play less of a role in the H-bonding network. ${ }^{17}$ This structural information suggests that the mTCR can more easily compensate for the loss of the 4-hydroxyl on the phytosphingosine chain, and therefore the activity of $\alpha$-GalCer vs. analogues 2 or 3 was comparable using the mTCR. In contrast, the hTCR is unable to accommodate changes at this position due to the vital Asp80 to Arg95 $\alpha$ H-bond. The Asp80 residue binds to both 3- and 4-hydroxyls and removal of the 4-hydroxyl may therefore alter the orientation of the Asp80 residue 
and disrupt the crucial binding to Arg95 $\alpha$. Based on our results it appears that the affinity of the hTCR for the CD1d-glycolipid complex is reduced upon removal of the 4-hydroxyl.

In the future, the importance of these H-bonding interactions could be confirmed by obtaining crystal structures of the ternary complexes with each of the 4-deoxy analogues. This would reveal changes to the CD1d-glycolipid-TCR H-bonding network upon removal of the glycolipid 4-hydroxyl. In addition the importance of the 4-hydroxyl on the activity of other glycolipids could be investigated.

\subsection{Conclusion}

In summary, $\alpha$-GalCer, sphinganine analogue $\mathbf{2}$, and sphingosine analogue $\mathbf{3}$ showed comparable activity in mice. The 4-deoxy analogues, $\mathbf{2}$ and $\mathbf{3}$, demonstrated significantly reduced hNKT cell activity. The reduced activity is attributed to species-specific differences in iNKT cell glycolipid recognition rather than reduced CD1d presentation. Our results suggest that differences in TCR structure influence the species-specific activities. From these results we suggest that glycolipids developed for potent CD1d-iNKT cell activity in humans should contain a ceramide base with the 4-hydroxyl present. 


\subsection{Experimental}

\section{Mice}

Breeding pairs of the inbred strains C57BL/6 were obtained from The Jackson Laboratories and from the Animal Resource Centre. All mice were maintained in the Biomedical Research Unit of the Malaghan Institute of Medical Research. $\mathrm{CD} \mathrm{d}^{-/}$mice, which are devoid of CD1d-restricted iNKT cells, were also used. ${ }^{22}$ The experiments were approved by the NZ national animal ethics committee and performed according to established national guidelines.

\section{Solubilisation of glycolipids}

$\alpha$-GalCer (Industrial Research Ltd, New Zealand) and synthesised glycolipids were tested to be endotoxin-free at a sensitivity of $0.125 \mathrm{EU} / \mathrm{mL}$ with an endotoxin kit (Pyrotell, Limulus Amebocyte Lysate). Each glycolipid (1 mg) was dissolved in $200 \mu \mathrm{L}$ of $\mathrm{CHCl}_{3} / \mathrm{MeOH} / \mathrm{H}_{2} \mathrm{O}(10: 10: 3)$, heated at $37^{\circ} \mathrm{C}$ for $15 \mathrm{~min}$ followed by sonication for $10 \mathrm{~min}$. The solution was then diluted to $200 \mu \mathrm{g} / \mathrm{mL}$ in $0.5 \%$ Tween/phosphate-buffered saline (PBS) and left to sit at $4{ }^{\circ} \mathrm{C}$ overnight. The glycolipid was then heated at $80{ }^{\circ} \mathrm{C}$ for $5 \mathrm{~min}$ followed by sonication for 5 min then cooled at $0{ }^{\circ} \mathrm{C}$ for $5 \mathrm{~min}(\mathrm{x} 2)$ and left to sit at $4{ }^{\circ} \mathrm{C}$ overnight. Aliquots of this stock solution were removed and further diluted to the appropriate concentrations used in each assay using sterile PBS.

\section{Antigen presenting cell maturation assay}

$100 \mu \mathrm{L}$ of glycolipid, diluted to $2 \mu \mathrm{g} / \mathrm{mL}$, was administered i.v. to groups of C57BL/6 mice $(n=3)$ and spleens were removed $20 \mathrm{~h}$ later. Spleens were teased through a cell strainer, red blood cells (RBCs) lysed with RBC lysis buffer, and the remaining cells labeled with anti-bodies for CD11c (clone HL3; BD Pharmingen), B220 (clone RA3-6B2 conjugated to A488; BD Pharmingen) CD86 (clone GL1 conjugated to PE; eBioscience) and propidium iodide (BD Pharmingen) and analysed by flow cytometry (BD FACSort). The same protocol was used to assess CD86 expression on $\mathrm{CD} 11 \mathrm{c}^{+}$and $\mathrm{B} 220^{+}$cells from $\mathrm{CD}^{-\mathrm{d}^{-/}}$ mice. 


\section{In vivo intracellular iNKT cell cytokine expression}

$100 \mu \mathrm{L}$ of glycolipid, diluted to $2 \mu \mathrm{g} / \mathrm{mL}$, was administered i.v. to groups of $\mathrm{C} 57 \mathrm{BL} / 6$ mice $(n=2)$ and spleens were removed $3 \mathrm{~h}$ later. Spleens were teased through a cell strainer, red blood cells (RBCs) lysed with RBC lysis buffer, and the remaining cells labeled with CD1d tetramer (human CD1d tetramer, clone 51.1, conjugated to PE, eBioscience, loaded with $\alpha$-GalCer, IRL), and antibodies for CD3 (clone 145-2C11 conjugated to FITC, eBioscience 11-0031-82), and B220 (clone RA3-6B2 conjugated to PerCP, BD Pharmingen), then fixed with formaldehyde (Sigma) at $4{ }^{\circ} \mathrm{C}$ over night. Wells were washed, then stained for intracellular IFN- $\gamma$ (clone XMG1.2, conjugated to APC, BD Pharmingen) or IL-4 (clone 11B11 conjugated to APC, BD Pharmingen) and analysed by flow cytometry (BD FACSort). Rat IgG (clone R3-34 conjugated to APC, BD Pharmingen) was used as an isotype control. Spleens from naïve control mice were similarly processed.

\section{Human iNKT cell proliferation assay.}

PBMCs were collected from healthy human volunteers, stored in liquid nitrogen, and thawed on the day of use. PBMCs (200,000 cells per well) were cultured with four fold serial dilutions of glycolipid 1, 2, 3 or media only (negative control) in wells containing $200 \mu \mathrm{L}$ cIMDM (5\% human AB serum) and incubated at $37^{\circ} \mathrm{C}$, $5 \% \mathrm{CO}_{2}$. After $24 \mathrm{~h}, 50 \mathrm{U} / \mathrm{mL}$ human IL-2 was added. The cells were harvested on day 7 for antibody labelling for live/dead fixable blue (Invitrogen), CD3 (clone SK7 conjugated to FITC, BD 349201), CD1d (human CD1d tetramer, clone 51.1, conjugated to PE, eBioscience, loaded with $\alpha$-GalCer, IRL), CD19 (clone SJ25C1 conjugated to APC, BD 340437) and flow cytometry (BD LSRII SORP).

\section{Culturing Murine cell lines}

The murine $\mathrm{CD} 8 \alpha^{+}$dendritic cell line $(\mathrm{DC} 2114)^{23}$ was cultured in a flask containing complete Iscove's Modified Dulbecco's Medium (cIMDM): IMDM + GlutaMax (Gibco), 5\% foetal bovine serum (Sigma-Aldrich), $0.1 \%$ 2mercaptoethanol (Invitrogen), 1\% penicillin-streptomycin (Invitrogen). The flask was incubated at $37{ }^{\circ} \mathrm{C}, 5 \% \mathrm{CO}_{2}$. Once the cells reached $80 \%$ confluency, the media was removed, and the adherent cells treated with trypsin, then split. Cells 
were used after at least one passage.

The murine NKT hybridoma cells (DN32.D3) ${ }^{24}$ were also cultured in a flask containing cIMDM and incubated at $37{ }^{\circ} \mathrm{C}, 5 \% \mathrm{CO}_{2}$. Once the cells reached $80 \%$ confluency, the non-adherent cells were removed and then split. Cells were used after at least one passage.

\section{Human monocyte derived Dendritic Cells}

PBMCs were collected from the blood of healthy human volunteers and suspended in Roswell Park Memorial Institute (RPMI) media (Gibco) containing $1 \%$ autologous human serum, human IL-4 (500 U/mL, PeproTech) and human granulocyte-macrophage colony-stimulating factor (hGMCSF) $(2,000 \mathrm{U} / \mathrm{mL}$, PeproTech). Cells were cultured for 7 days at $37{ }^{\circ} \mathrm{C}, 5 \% \mathrm{CO}_{2}$, and half the media was replaced every two days. At day 7, the non-adherent cells were gently decanted and washed three times (PBS) before use.

\section{Human iNKT cell clones}

Human $V \alpha 24 V \beta 11$ iNKT cell clones were received from Rod Dunbar and Anna Brooks (Auckland University, NZ) and stored in liquid nitrogen. Before use the cells were defrosted, and washed. The cells were then rested for 1 to 2 days in a 24 well plate (2 million cells per well) with RPMI media containing 5\% AB human serum (Invitrogen), human IL-2 (100 U/mL, in house $\left.{ }^{*}\right)$, human IL-7 (0.1 $\mathrm{mg} / \mathrm{mL}$, PeproTech), and 1\% penicillin-streptomycin (Invitrogen). After 1 to 2 days cells were gently removed from the 24 well plate and washed 2 to 3 times to remove cytokines.

\section{In vitro dendritic and iNKT cell culture assay}

DCs $(25,000$ per well, human or murine) and iNKT cells (100,000 per well, human or murine) were cultured together with two or four fold dilutions of glycolipid 1, 2, or 3 (triplicate repeats) with $250 \mu \mathrm{L}$ media (cIMDM for mDC with mNKT, or cRPMI for hDC with $\mathrm{hNKT}$ or hDC with $\mathrm{mNKT}$ ), in a 96 well

\footnotetext{
* Recombinant human IL-2 was produced using stationary phase cultures of the IL2L6 cell line, generated by modifying the murine J558 parental line to secrete the full-length human IL-2 protein
} 
plate. Media, DCs, and NKT cell only and media and NKT cells only wells were included as negative controls, each in triplicate. Cells were incubated overnight at $37{ }^{\circ} \mathrm{C}, 5 \% \mathrm{CO}_{2}$ and $2 \times 110 \mu \mathrm{L}$ supernatant removed. The supernatant IL-2 and IFN- $\gamma$ levels were then measured. IL-2 was measured by determining the proliferation of an IL-2 dependant T cell line (see below). IFN- $\gamma$ produced by murine iNKT cells was measured using BioPlex. IFN- $\gamma$ produced by human iNKT cells was measured using ELISA.

\section{Measuring IL-2 production}

Supernatant IL-2 was measured by determining the proliferation of the IL-2 dependant murine T-helper cell-derived line (HT-2).

\section{HT-2 cell culture}

HT-2 cells were cultured in a flask containing cIMDM in the presence of IL-2 $(200 \mathrm{U} / \mathrm{mL})$. Once cells reached $80 \%$ confluency, the non-adherent cells were removed and then split. Cells were used after at least one passage. Before use cells were washed thoroughly with PBS to remove IL-2.

HT-2 cells were then plated out in a flat-bottom 96 -well plate $(5,000$ cells per well) and $100 \mu \mathrm{L}$ supernatant added. A standard curve was constructed by incubating HT-2 cells with known concentrations of IL-2 $(200-0 \mathrm{U} / \mathrm{mL}$ in five fold dilution). HT-2 cells proliferation was measured using $\left[{ }^{3} \mathrm{H}\right]$ thymidine incorporation over the final $6 \mathrm{~h}$, and measured with a beta-counter (Wallac).

\section{Statistical analysis}

Statistical significance was analysed using one-way analysis of variants (ANOVA) followed by Tukey's Multiple Comparison Test to compare the means of every treatment group with every other treatment group. Statistical calculations were performed using Graphpad Prism ${ }^{\circledR}$ Version 5 statistical package (Graphpad Software Inc., San Diego, CA, USA). 


\subsection{References}

(1) Berkers, C. R.; Ovaa, H. Trends Pharmacol. Sci. 2005, 26, 252-257.

(2) Wu, D.; Fujio, M.; Wong, C.-H. Bioorg. Med. Chem. 2008, 16, 10731083.

(3) Savage, P. B.; Teyton, L.; Bendelac, A. Chem. Soc. Rev. 2006, 35, 771779.

(4) Silk, J. D.; Hermans, I. F.; Gileadi, U.; Chong, T. W.; Shepherd, D.; Salio, M.; Mathew, B.; Schmidt, R. R.; Lunt, S. J.; Williams, K. J.; Stratford, I. J.; Harris, A. L.; Cerundolo, V. J. Clin. Invest. 2004, 114, 1800-1811.

(5) Hermans, I. F.; Silk, J. D.; Gileadi, U.; Masri, S. H.; Shepherd, D.; Farrand, K. J.; Salio, M.; Cerundolo, V. J. Immunol. 2007, 178, 27212729.

(6) Brossay, L.; Naidenko, O.; Burdin, N.; Matsuda, J.; Sakai, T.; Kronenberg, M. J. Immunol. 1998, 161, 5124-5128.

(7) Yin, N.; Long, X.; Goff, R. D.; Zhou, D.; Cantu III, C.; Mattner, J.; Saint Mezard, P.; Teyton, L.; Bendelac, A.; Savage, P. B. ACS Chem. Biol. 2009, 4, 191-197.

(8) Xia, C.; Schmann, J.; Emmanuel, R.; Zhang, Y.; Chen, W.; Zhang, W.; De Libero, G.; Wang, G. P. J. Med. Chem. 2007, 50, 3489-3496.

(9) Brossay, L.; Chioda, M.; Burdin, N.; Koezuka, Y.; Casorati, G.; Dellabona, P.; Kronenberg, M. J. Exp. Med. 1998, 188, 1521-1528.

(10) Morita, M.; Motoki, K.; Akimoto, K.; Natori, T.; Sakai, T.; Sawa, E.; Yamaji, K.; Koezuka, Y.; Kobayashi, E.; Fukushima, H. J. Med. Chem. 1995, 38, 2176-2187.

(11) Sidober, S.; Hammond, K. J. L.; Bénazet-Sidobre, L.; Maltsev, S. D.; Richardson, S. K.; Ndonye, R. M.; Howell, A. R.; Sakai, T.; Besra, G. S.; Porcelli, S. A.; Kronenberg, M. Proc. Natl. Acad. Sci. 2003, 101, 1225412259.

(12) Lacône, V.; Hanault, J.; Pipelier, M.; Blot, V.; Lecourt, T.; Rocher, J.; Turcot-Dudois, A.-L.; Marionneau, S.; Douillard, J.-Y.; Clément, M.; Le Pendu, J.; Bonneville, M.; Micouin, L.; Dubreuil, D. J. Med. Chem. 2009, 52, 4960-4963.

(13) Mccarthy, C.; Shepherd, D.; Fleire, S.; Stronge, V.; Koch, M.; Illarionov, P.; Bossi, G.; Salio, M.; Denkberg, G.; Reddington, F.; Tarlton, A.; Reddy, B.; Schmidt, R.; Reiter, Y.; Griffiths, G.; Van Der Merwe, P.; Besra, G.; Jones, E.; Batista, F.; Cerundolo, V. J. Exp. Med. 2007, 204, 1131-1144.

(14) Florence, W. C.; Xia, C.; Gordy, L. E.; Chen, W.; Zhang, Y.; ScottBrowne, J.; Kinjo, Y.; Yu, K. O. A.; Keshipeddy, S.; Pellicci, D. G.; Patel, O.; Kjer-Nielsen, L.; McCluskey, J.; Godfrey, D. I.; Rossjohn, J.; Richardson, S. K.; Porcelli, S. A.; Howell, A. R.; Hayakawa, K.; Gapin, L.; Zajonc, D. M.; Wang, P. G.; Joyce, S. EMBO J. 2009, 28, 3579-3590.

(15) Li, X.; Shiratsuchi, T.; Chen, G.; Dellabona, P.; Casorati, G.; Franck, R. W.; Tsuji, M. J. Immunol. 2009, 183, 4415-4421.

(16) Nadas, J.; Li, C.; Wang, G. P. J. Chem. Inf. Model. 2009, 49, 410-423.

(17) Li, Y.; Girardi, E.; Wang, J.; Yu, E. D.; Painter, G. F.; Kronenberg, M.; Zajonc, D. M. J. Exp. Med. 2010, 207, 2383-2393. 
(18) Koch, M.; Stronge, V. S.; Shepherd, D.; Gadola, S. D.; Mathew, B.; Ritter, G.; Fersht, A. R.; Besra, G. S.; Schmidt, R. R.; Jones, E. Y.; Cerundolo, V. Nat. Immunol. 2005, 6, 819-826.

(19) Schiefner, A.; Fujio, M.; Wu, D.; Wong, C.-H.; Wilson, I. A. J. Mol. Biol. 2009, 394, 71-82.

(20) Borg, N. A.; Wun, K. S.; Kjer-Nielsen, L.; Wilce, M. C. J.; Pellicci, D. G.; Koh, R.; Besra, G. S.; Bharadwaj, M.; Godfrey, D. I.; McCluskey, J.;

Rossjohn, J. Nature 2007, 448, 44-49.

(21) Zajonc, D. M.; Savage, P. B.; Bendelac, A.; Wilson, I. A.; Teyton, L. J. Mol. Biol. 2008, 377, 1104-1116.

(22) Chen, Y.-H.; Chiu, N. M.; Mandal, M.; Wang, N.; Wang, C.-R. Immunity 1997, 6, 459-467.

(23) Steiner, Q.-G.; Ottem, L. A.; Hicks, M. J.; Kaya, G.; Grosjean, F.; Saeuberli, E.; Lavanchy, C.; Beermann, F.; McClain, K. L.; Acha-Orbea, H. Blood 2008, 111, 2073-2082.

(24) Bendelac, A.; Lantz, O.; Quimby, M. E.; Yewdell, J. W.; Bennink, J. R.; Brutkiewicz, R. R. Science 1995, 268, 863-865. 


\section{Chapter 4: Protecting Group Free Synthesis of A Five Membered Azasugar ${ }^{1}$}

\subsection{Introduction}

As noted inhibitors of glycosidases, azasugars have enormous potential in the treatment of diseases such as viral infection, bacterial infection, lysosomal storage disorders, cancer and diabetes (Chapter 1). ${ }^{2,3}$ However, due to their limited availability, only a few have been widely studied for their therapeutic potential. The ability to rapidly and efficiently synthesise azasugars provides the opportunity to evaluate their inhibitory properties and investigate their therapeutic potential. Although there have been a number of elegant strategies for the synthesis of five membered azasugars, the vast majority of these employ standard protecting group manipulations (see Chapter 1.3 and references cited therein). The focus of the work in this chapter is the development of methodology that allows for the protecting group free synthesis of five membered azasugars (I, Scheme 4.1). Key to achieving this goal was the development of two synthetic transformations, a novel carbamate cyclisation (III to II), and the Vasella reductive amination to produce primary amines (IV to III). To develop this methodology we chose to synthesise 1,4-dideoxy-1,4-imino-D-xylitol, which is a weak glycogen phosphorylase $\mathrm{b}$ inhibitor ${ }^{4}$ that was first isolated in $1985^{5,6,7}$ and has been synthesised several times before. ${ }^{8-11}$ 


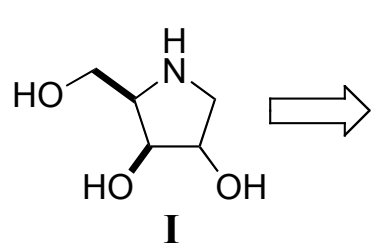<smiles>CC=CC=CC=CC(O)C(O)CN</smiles><smiles>CO[C@H]1OC(CI)C(O)C1O</smiles>

Scheme 4.1. Retrosynthesis of target five membered azasugars.

\subsection{Results and Discussion}

\section{Carbamate Annulation}

Our first representative synthesis of a five membered azasugar commenced with the conversion of D-xylose (1, Scheme 4.2) into its methyl furanoside via a Fisher glycosidation. Treatment of the crude product with iodine and triphenylphosphine gave methyl 5-iodofuranoside 2 in a $61 \%$ yield over two steps. ${ }^{12}$ Iodoglycoside 2 was then refluxed with zinc and catalytic amount of acetic acid, according to the conditions of Vasella, and TLC analysis showed complete conversion of the starting material to a less mobile product. Attempts to isolate the aldehyde, however, proved problematic due to the propensity of hydroxy aldehydes to readily polymerise. In contrast, in situ imine formation using (diphenylmethyl)amine and subsequent reduction with sodium cyanoborohydride led to the smooth formation of amine $\mathbf{3}$ in a three-step, one-pot procedure. Deprotection of crude amine 3, using TFA and $\mathrm{Et}_{3} \mathrm{SiH}$, gave linear amine 4 as the TFA salt in $93 \%$ over the two steps with a minimal use of protecting groups. 


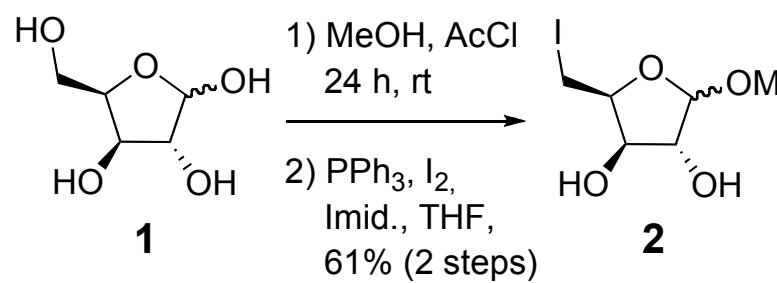<smiles>OC[C@H]1NC[C@@H](O)[C@@H]1O</smiles>

8

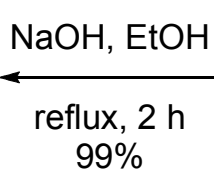

$99 \%$

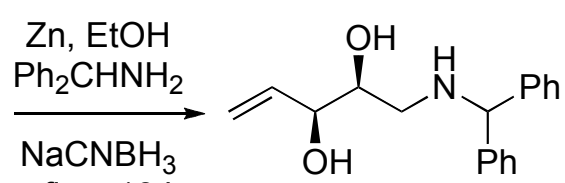

3

TFA, $\mathrm{Et}_{3} \mathrm{SiH}$ reflux, $18 \mathrm{~h}$ $93 \%$ (from 2)

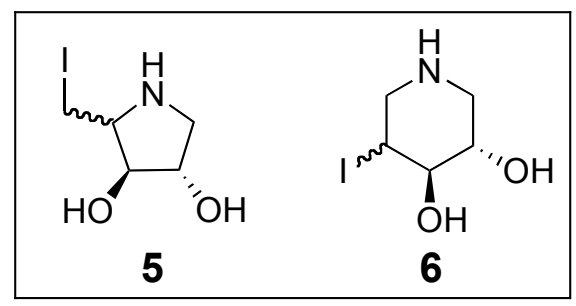

Scheme 4.2. Synthesis of $c i s-2,3$-disubstituted 1,4-dideoxy-1,4-imino-D-xylitol using novel annulation methodology.

With the olefinic amine $\mathbf{4}$ in hand, we set out to develop the carbamate annulation reaction and produce the azasugar ring via halocyclisation. We proposed that iodide 5 could be prepared according to literature procedures and then reacted in situ, with a $\mathrm{CO}_{2}$ source, to generate the desired carbamate. Initial attempts to produce cyclic iodide 5 using $N$-iodosuccinimide (NIS) gave a complex mixture of products that included the five membered iodoazasugars 5 and the six membered iodoazasugars $\mathbf{6}$, presumably formed from 5 via aziridine formation and subsequent opening of the three membered ring by the nucleophilic iodide. ${ }^{13}$ In an attempt to overcome this problem, amine $\mathbf{4}$ was subjected to a solution of $\mathrm{I}_{2}$ and $\mathrm{NaHCO}_{3}$ in water. This solution was stirred overnight at room temperature, at which point TLC analysis demonstrated complete consumption of starting material. Attempts to extract the product using standard work-up procedures were unsuccessful, as the product was more soluble in the aqueous layer than the organic layer. Instead, the reaction mixture was concentrated in vacuo and an NMR of the crude reaction mixture was taken directly. ${ }^{1} \mathrm{H}$ NMR analysis revealed the presence of only one product, however, further analysis by ${ }^{13} \mathrm{C}$ and $2 \mathrm{D} N \mathrm{NMR}$ 
was not possible at this stage due to the high salt content of the sample. Purification of the product was complicated by the inability of the TLC dips $\left(\mathrm{I}_{2}\right.$; ninhydrin; $\mathrm{H}_{2} \mathrm{SO}_{4} ; \mathrm{KMnO}_{4}$; dragendorff $-\mathrm{BiO}\left(\mathrm{NO}_{3}\right), \mathrm{KI}, \mathrm{AcOH}$, and $\mathrm{H}_{2} \mathrm{O}$; and ceric ammonium molybdate - $\left(\mathrm{NH}_{4}\right)_{6} \mathrm{Mo}_{7} \mathrm{O}_{24} \cdot 4 \mathrm{H}_{2} \mathrm{O}, \mathrm{Ce}\left(\mathrm{SO}_{4}\right)_{2}$, and $\left.\mathrm{H}_{2} \mathrm{SO}_{4}\right)$ to stain the product. This observation suggested that the product was not azasugar 5, as this product stained in ninhydrin and $\mathrm{I}_{2}$. Nevertheless, purification could be achieved using silica gel gradient column chromatography with the product consistently eluted from the column using a solution of 5\% methanol in ethyl acetate.

Extensive NMR $\left({ }^{1} \mathrm{H},{ }^{13} \mathrm{C}, \mathrm{COSY}, \mathrm{HMBC}, \mathrm{HSQC}\right)$ analysis of the purified material revealed the product contained six carbon centres; one carbonyl $\left({ }^{13} \mathrm{C}\right.$ NMR $\delta 164.4 \mathrm{ppm}$ ), two methylene groups and three methine centres (see appendix). HMBC correlations from the carbonyl carbon to both methylene groups and to one methine centre indicated that the carbonyl was attached to the molecule. In addition, the protons on one of the methylene groups had ${ }^{1} \mathrm{H}$ chemical shifts of 4.64 and 4.51, suggesting this $\mathrm{CH}_{2}$ was next to an ester like functional group. Mass spectrometric analysis indicated that the product had an exact $\mathrm{m} / \mathrm{z}$ of 160.0605 suggesting the product had the chemical formula $\mathrm{C}_{6} \mathrm{H}_{9} \mathrm{NO}_{4}$. With this information, and further analysis of the NMR spectra the structure of the product was determined to be that of carbamate 7. This result was exciting as we had hoped to be able to prepare carbamate 7 from alkenylamine 4 using an iodine promoted cyclisation. This methodology enabled the carbamate to be formed directly from the alkenylamine, in addition only a single product was observed from the reaction of alkenylamine 4 with $\mathrm{I}_{2}$ and $\mathrm{NaHCO}_{3}$, indicating the reaction was stereoselective. In an attempt to understand the $\mathrm{CO}_{2}$ source, and check that the $\mathrm{CO}_{2}$ was not being absorbed from the air, the unprotected amine 4 was subjected to iodine in the presence of DBU, however, this did not lead to carbamate 7 and a complex mixture of products was observed. This result was similar to that observed using NIS implicating $\mathrm{NaHCO}_{3}$ as the $\mathrm{CO}_{2}$ source in this reaction. 
Although the mechanism of the cyclisation reaction has not yet been proven, we propose that reaction of alkenylamine 9 with $\mathrm{I}_{2}$ activates the double bond, through formation of iodonium ion $\mathbf{1 0}$ (Scheme 4.3). This enables intramolecular nucleophilic attack by the internal amine to form the intermediate haloamine $\mathbf{1 1}$. The haloamine then reacts with $\mathrm{CO}_{2}$, from the $\mathrm{NaHCO}_{3}$, to form adduct 12 , which displaces the iodide, forming target carbamate $\mathbf{1 3 .}$

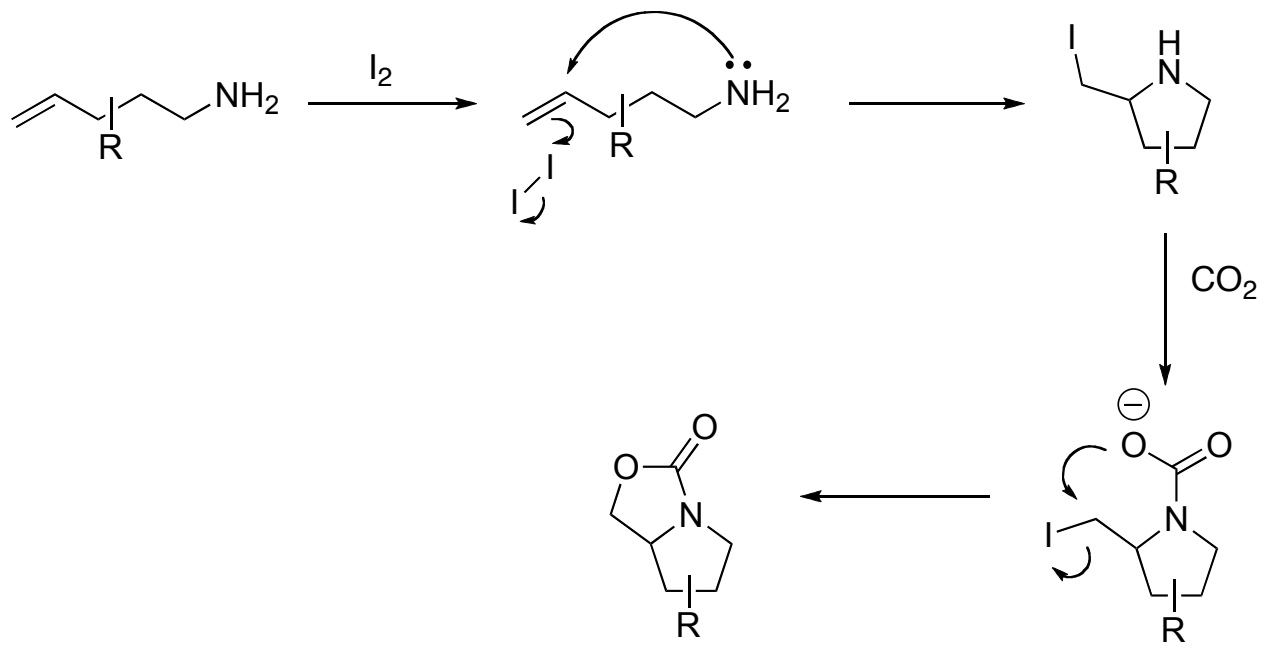

Scheme 4.3. Proposed mechanism for the formation of cyclic carbamates from alkenylamines.

Another remarkable feature of the halocyclisation/carbonylation is that it proceeds with complete diastereo- and regioselectively to give the five-membered 3,4-cis products exclusively. The 3,4-cis configuration is in agreement with the observation that iodine promoted intramolecular cyclisations are often directed by the allylic hydroxyl to give the cis-product. ${ }^{14-16}$ The stereochemistry of carbamate 7 was unequivocally proven by hydrolysis to form the desired 1,4-dideoxy-1,4imino-D-xylitol (8) in excellent yield (99\%). The data matched that previously reported. ${ }^{17}$ (See Chapter 6 for discussions concerning the diastereoselectivity observed during the carbamate annulation reaction.)

\section{Reductive Amination}

Given the success of our carbamate annulation, we set out to develop methodology for the synthesis of alkenylamine $\mathbf{4}$ that avoids the use of protecting groups. It is well known that the use of ammonia or ammonium salts in reductive 
amination reactions typically results in the formation of amine dimers, due to the lower nucleophilicity of ammonia compared to the primary amine product of the reductive amination (see Chapter 1.3). We proposed that by increasing the concentration of ammonia (or ammonium salt) preferential formation of primary amine 4 could be achieved. To explore this, we first investigated the influence that the ammonium salt had on the reductive amination reaction. To this end, a variety of amine salts were used including $\mathrm{NH}_{4} \mathrm{Cl},\left(\mathrm{NH}_{4}\right)_{2} \mathrm{CO}_{3}, \mathrm{NH}_{4} \mathrm{HCO}_{3}$ and $\mathrm{NH}_{4} \mathrm{OAc}$ (Table 4.1, Entries 1-4). With the exception of the less soluble carbonate, the addition of 10 equivalents of salt gave very similar results with monomer being formed in modest yield (40\%), and with mediocre selectivity $(2: 3,4: 14)$. Next, taking advantage of the greater solubility of $\mathrm{NH}_{4} \mathrm{OAc}$ in $\mathrm{EtOH}$, we increased the concentration of $\mathrm{NH}_{4} \mathrm{OAc}$ in an attempt to improve monomer formation. An increase from 10 to 100 equivalents of $\mathrm{NH}_{4} \mathrm{OAc}$ proved beneficial with monomer 4 being formed in a 1:1 ratio (Entry 5). Increasing the acetate concentration, through use of a saturated solution of $\mathrm{NH}_{4} \mathrm{OAc}$ in $\mathrm{EtOH}$, again showed a marked improvement in the formation of the monomer, both in yield (60\%) and selectivity (3:2, Entry 6). 
Table 4.1. Reductive amination of furan 2.<smiles>COC1O[C@H](CI)[C@@H](O)[C@H]1O</smiles>

2

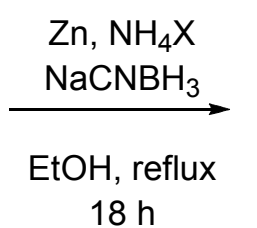

$18 \mathrm{~h}$<smiles>C=C[C@H](O)[C@@H](O)C[NH3+]</smiles>

4<smiles>C=C[C@H](O)[C@@H](O)CNC[C@H](O)[C@H](O)C=C</smiles>

14

\begin{tabular}{|c|c|c|c|}
\hline Entry & Conditions $^{\mathrm{a}, \mathrm{b}}$ & Ratio $4: 14^{\mathrm{c}}$ & $\begin{array}{c}\text { Yield } \\
\text { (monomer) }^{d}\end{array}$ \\
\hline 1 & $\left(\mathrm{NH}_{4}\right)_{2} \mathrm{CO}_{3}$ (10 eq.) & $3: 7$ & $30 \%$ \\
\hline 2 & $\mathrm{NH}_{4} \mathrm{Cl}$ (10 eq.) & $2: 3$ & $40 \%$ \\
\hline 3 & $\mathrm{NH}_{4} \mathrm{HCO}_{3}$ (10 eq.) & $2: 3$ & $40 \%$ \\
\hline 4 & $\mathrm{NH}_{4} \mathrm{OAc}$ (10 eq.) & $2: 3$ & $40 \%$ \\
\hline 5 & $\mathrm{NH}_{4} \mathrm{OAc}$ (100 eq.) & $1: 1$ & $50 \%$ \\
\hline 6 & $\mathrm{NH}_{4} \mathrm{OAc}$ (sat.) & $3: 2$ & $60 \%$ \\
\hline 7 & $\mathrm{NH}_{4} \mathrm{OAc}$ (sat.), $\mathrm{AcOH}$ (10 eq.) & $4.5: 5.5$ & $45 \%$ \\
\hline 8 & $\mathrm{NH}_{3}\left(30 \%\right.$ solution in $\left.\mathrm{H}_{2} \mathrm{O}\right)$ & - & degradation \\
\hline 9 & $\mathrm{NH}_{3}$ (60 eq.), TFA (2 eq.) & $5.5: 4.5$ & $55 \%$ \\
\hline 10 & $\mathrm{NH}_{3}$ (60 eq.), $\mathrm{AcOH}$ (7 eq.) & $3: 2$ & $60 \%$ \\
\hline 11 & $\mathrm{NH}_{4} \mathrm{OAc}$ (sat.), $\mathrm{NH}_{3}$ (10 eq.) & $4: 1$ & $80 \%$ \\
\hline 12 & $\mathrm{NH}_{4} \mathrm{OAc}$ (sat.), $\mathrm{NH}_{3}$ (60 eq.) & $>20: 1$ & $95 \% \mathrm{e}^{\mathrm{e}}$ \\
\hline
\end{tabular}

${ }^{\mathrm{a}}$ All reactions were performed by the addition of activated $\mathrm{Zn}$ (5 eq.), amine (as indicated) and $\mathrm{NaCNBH}_{4}$ (2 eq.) to a solution of the iodofuranoside in ethanol (20 $\mathrm{mL} / \mathrm{mmol}$ ). ${ }^{\text {b }} \mathrm{NH}_{3}$ was added as a $30 \%$ solution in $\mathrm{H}_{2} \mathrm{O}$. ${ }^{\mathrm{c}}$ Ratios calculated from the integral values of the corresponding ${ }^{1} \mathrm{H}$ NMR signals (4:14). ${ }^{\mathrm{d}}$ Molar yields. ${ }^{\mathrm{e}}$ Isolated yield. 
As monomer 4 is both more nucleophilic, but also more basic than ammonia, we postulated that the correct balance between free ammonia and protonated monomeric amine would be critical in optimising the formation of amine 4 . To explore this, a series of experiments were performed whereby the ammonia to ammonium salt ratio was altered. First, the addition of acetic acid to a saturated solution of $\mathrm{NH}_{4} \mathrm{OAc}$ (Entry 7) led to a reduction in both yield and selectivity compared to ammonium acetate alone ( $c f$. Entry 6). This suggested that a more basic reaction medium was required. Use of $30 \%$ aqueous ammonia, as the amine source, with various concentrations of acids was then assessed. Without acid (Entry 8), degradation of starting material occurred and no product could be detected. The use of TFA or acetic acid (Entries 9 and 10) led to product formation, albeit without significant improvements in monomer yield. In contrast, adding ammonia (10 eq.) to a saturated solution of $\mathrm{NH}_{4} \mathrm{OAc}$ in $\mathrm{EtOH}$ provided a marked improvement in both selectivity and monomer yield $(4: 1,4: 14,80 \%$, Entry 11). Further optimisation via the addition of 60 equivalents of ammonia (Entry 12), resulted in almost exclusive formation of amine 4 and in excellent isolated yield (95\%).

Due to the absence of protecting groups and the associated water solubility of monomer 4, removal of the excess ammonium acetate was initially problematic. Optimal conditions were found when a solution of $\mathrm{HCl}$ in iso-propanol was added to the reaction mixture. Reaction of $\mathrm{NH}_{4} \mathrm{OAc}$ with $\mathrm{HCl}$ gave $\mathrm{NH}_{4} \mathrm{Cl}$ and $\mathrm{AcOH}$. The AcOH could then be evaporated, and the resulting mixture dissolved in EtOH. $\mathrm{NH}_{4} \mathrm{Cl}$ is much less soluble in ethanol than $\mathrm{NH}_{4} \mathrm{OAc}$, and could be removed by filtration through celite. Following silica gel flash column chromatography, monomer 4 was isolated in a 95\% yield (as its $\mathrm{HCl}$ salt) and subsequently cyclised to carbamate 7 , in a quantitative yield. To the best of our knowledge, this methodology provides the first efficient synthesis of a primary amine via reductive amination without any need for functional group protection. The use of this remarkably efficient transformation, in combination with the carbamate annulation, is ably demonstrated by the five step synthesis of azasugar $\mathbf{8}$, in $57 \%$ overall yield, the best reported yield to date. 


\subsection{Conclusion}

Herein we have reported a novel, stereoselective, five step strategy for the synthesis of 1,4-dideoxy-1,4-imino-D-xylitol (8) in 57\% yield. This strategy is not merely competitive in yield and the number of linear steps, but also does not require protecting groups. Furthermore, we have identified two novel reaction methodologies: the first for the stereoselective formation of cyclic carbamates from olefinic amines, and the second for the formation of primary amines without the need for protecting groups. Our two new synthetic methodologies are important additions to the chemist's toolbox and we believe that both methodologies will find wide application in the synthesis of azasugars and other organic molecules.

\subsection{Experimental}

\section{General Experimental}

Unless otherwise stated all reactions were performed under atmospheric air. THF (Lab-Scan) was distilled from $\mathrm{LiAlH}_{4}$ prior to use. $\mathrm{H}_{2} \mathrm{O}, \mathrm{MeOH}$ (Pure Science), EtOAc (Pure Science), and petroleum ether (Pure Science) were distilled prior to use. EtOH (absolute, Pure Science), AcOH (Ajax Finechem), DCM (LabServ), $30 \%$ aqueous $\mathrm{NH}_{3}$ (J. T. Baker Chemical Co.), Et ${ }_{2} \mathrm{O}$ (Merck), TFA (Aldrich), Dxylose (Sigma-Aldrich), $\mathrm{AcCl}(\mathrm{B} \& \mathrm{M}), \mathrm{PPh}_{3}$ (Merck), imidazole (Aldrich), $\mathrm{I}_{2}$ (BDH), triethylsilane (Fluka), $\mathrm{NaCNBH}_{3}$ (Aldrich), aminodiphenylmethane (Aldrich), $\mathrm{NaOH}$ (Pure Science), and $\mathrm{NH}_{4} \mathrm{OAc}$ (AnalaR) were used as received. $\mathrm{Zn}$ dust was activated by the careful addition of conc. $\mathrm{H}_{2} \mathrm{SO}_{4}$, washed with EtOH (three times) and petroleum ether (three times), and stored under dry hexanes. All solvents were removed by evaporation under reduced pressure. Reactions were monitored by TLC-analysis on Macherey-Nagel silica gel coated aluminium sheets $(0.20 \mathrm{~mm}$, silica gel 60) with detection by UV-absorption $(254 \mathrm{~nm})$, by spraying with $20 \% \mathrm{H}_{2} \mathrm{SO}_{4}$ in EtOH followed by charring at $\sim 150{ }^{\circ} \mathrm{C}$, by dipping in $\mathrm{I}_{2}$ in silica, or by spraying with a solution of ninhydrin $(3.3 \mathrm{~g})$ in $\mathrm{EtOH}(100$ $\mathrm{mL}$ ) followed by charring at $\sim 150{ }^{\circ} \mathrm{C}$. Column chromatography was performed on Pure Science silica gel (40-63 micron). Dowex ${ }^{\circledR}$ W50-X8 acidic resin (Sigma) and Dowex $^{\circledR} 1 \mathrm{X} 4-50$ basic resin (Sigma) were used for ion exchange chromatography 
and HP-20 (Supelco) for reverse phase chromatography. High-resolution mass spectra were recorded on a Waters Q-TOF Premier ${ }^{\mathrm{TM}}$ Tandem Mass Spectrometer using positive electro-spray ionisation. Optical rotations were recorded using a Perkin-Elmer 241 polarimeter at the sodium D-line. Infrared spectra were recorded as thin films using a Bruker Tensor 27 FTIR spectrometer, equipped with an Attenuated Total Reflectance (ATR) sampling accessory, and are reported in wave numbers $\left(\mathrm{cm}^{-1}\right)$. Nuclear magnetic resonance spectra were recorded at 20 ${ }^{\circ} \mathrm{C}$ in $\mathrm{D}_{2} \mathrm{O}$ or $\mathrm{CDCl}_{3}$ using either a Varian Unity-INOVA operating at $300 \mathrm{MHz}$ or

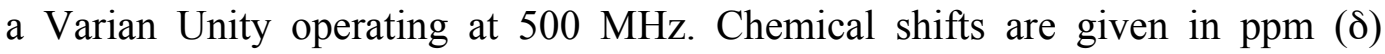
relative to tetramethylsilane. NMR peak assignments were made using COSY, HSQC and HMBC experiments.

\section{Methyl 5-deoxy-5-iodo- $\alpha / \beta$-D-xyloside (2).}

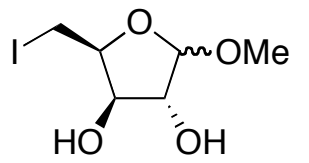

To a solution of D-xylose (4.16 g, $25.4 \mathrm{mmol})$ in $\mathrm{MeOH}$ (127 $\mathrm{mL}), \mathrm{AcCl}(380 \mu \mathrm{L})$ was added and the reaction was stirred at room temperature for $24 \mathrm{~h}$. The reaction was neutralised by the addition of Dowex $\left(\mathrm{OH}^{-}\right)$, filtered and concentrated. The resulting oil could be used without further purification or could be purified by flash chromatography $(\mathrm{MeOH} / \mathrm{EtOAc}, 1 / 9$, $\mathrm{v} / \mathrm{v}$ ) to give the methyl furanoside. To a solution of methyl xyloside (4.17 g, 25.4 mmol) in dry THF $(140 \mathrm{~mL})$ under an atmosphere of argon, $\mathrm{PPh}_{3}(10.0 \mathrm{~g}, 38.1$ mmol) and imidazole (3.45 g, $50.8 \mathrm{mmol})$ were added. $\mathrm{I}_{2}(9.67 \mathrm{~g}, 38.1 \mathrm{mmol})$ in dry THF $(38 \mathrm{~mL})$ was cannulated into the reaction vessel. The reaction was refluxed for $2 \mathrm{~h}$, then cooled, filtered and concentrated under reduced pressure. The product was taken up in petroleum ether/EtOAc, 3/1, v/v, and filtered through a silica plug to remove excess iodine. The product was further purified by column chromatography on reverse phase HP-20 beads $(\mathrm{MeOH} /$ water, 5/1, v/v) to give xyloside 2 as colourless oil in a 1:1.3 ratio of $\alpha$ - and $\beta$-anomers $(61 \%, 4.24 \mathrm{~g}$, $15.5 \mathrm{mmol}) .{ }^{12} \mathrm{R}_{f}=0.65($ EtOAc $/ \mathrm{MeOH}, 9 / 1, \mathrm{v} / \mathrm{v}) ;[\alpha]_{\mathrm{D}}{ }^{21}=-19.7\left(c=1.5, \mathrm{CHCl}_{3}\right)$; IR (film) 3446, 1216, $770 \mathrm{~cm}^{-1} .{ }^{1} \mathrm{H}$ NMR $\left(500 \mathrm{MHz} \mathrm{CDCl}_{3}\right) \delta 5.06\left(\mathrm{~d}, J_{1,2}=4.4\right.$ $\mathrm{Hz}, 1 \mathrm{H}, \mathrm{H}-1 \alpha), 4.93(\mathrm{~s}, 1 \mathrm{H}, \mathrm{H}-1 \beta), 4.60\left(\mathrm{dt}, J_{3,4}=3.9, J_{4,5 \mathrm{a}}=J_{4,5 \mathrm{~b}}=7.7 \mathrm{~Hz}, 1 \mathrm{H}\right.$, $\mathrm{H}-4 \beta$ ), 4.40 (m, $1 \mathrm{H}, \mathrm{H}-4 \alpha$ ), 4.29 (dd, $\left.J_{2,3}=3.3, J_{3,4}=4.6 \mathrm{~Hz}, 1 \mathrm{H}, \mathrm{H}-3 \alpha\right), 4.28$ (s, $1 \mathrm{H}, \mathrm{H}-2 \beta), 4.17\left(\mathrm{dd}, J_{1,2}=4.4, J_{2,3}=3.3 \mathrm{~Hz}, 1 \mathrm{H}, \mathrm{H}-2 \alpha\right), 4.14\left(\mathrm{~d}, J_{3,4}=3.9 \mathrm{~Hz}\right.$, $1 \mathrm{H}, \mathrm{H}-3 \beta$ ), 3.51 (s, 3H, OMe- $\alpha$ ), 3.40 (s, 3H, OMe- $\beta$ ), 3.32 (d, $J_{4,5}=7.7 \mathrm{~Hz}, 2 \mathrm{H}$, 
H-5), $3.31\left(\mathrm{dd}, J_{4,5 \mathrm{a}}=7.6, J_{5 \mathrm{a}, 5 \mathrm{~b}}=9.8 \mathrm{~Hz}, 1 \mathrm{H}, \mathrm{H}-5 \mathrm{a} \alpha\right), 3.25\left(\mathrm{dd}, J_{4,5 \mathrm{~b}}=6.1, J_{5 \mathrm{a}, 5 \mathrm{~b}}=\right.$ $9.8 \mathrm{~Hz}, 1 \mathrm{H}, \mathrm{H}-5 \mathrm{~b} \alpha$ ), 2.9 (br s, $1 \mathrm{H}, \mathrm{OH}), 2.8$ (br s, $1 \mathrm{H}, \mathrm{OH}) ;{ }^{13} \mathrm{C} \mathrm{NMR}(75 \mathrm{MHz}$, $\left.\mathrm{CDCl}_{3}\right) 109.0$ (C1- $\beta$ ), $102.2(\mathrm{C} 1-\alpha), 83.7$ (C4- $\left.\beta\right), 79.7$ (C2- $\left.\beta\right), 79.1$ (C4- $\left.\alpha\right), 78.4$ (C2- $\alpha$ ), 76.9 (C3- $\alpha$ ), 76.0 (C3- $\beta$ ), 56.2 (OMe- $\alpha$ ), 55.5 (OMe- $\beta$ ), 1.9 (C5- $\beta$ ), 1.6 (C5- $\alpha$ ); HRMS(ESI) $m / z$ calcd. for $\left[\mathrm{C}_{6} \mathrm{H}_{11} \mathrm{O}_{4} \mathrm{I}+\mathrm{Na}\right]^{+}:$296.9594, obsd.: 296.9601.<smiles>C=CC(O)C(O)CNC(c1ccccc1)c1ccccc1</smiles>

\section{$(2 S, \quad 3 S)-1-(D i p h e n y l m e t h y l) a m i n o-p e n t-4-e n e-2,3-$} diol (3). To a solution of iodopyranoside 2 (200 mg, $0.73 \mathrm{mmol})$ in EtOH $(20 \mathrm{~mL})$ was added water $(500$ $\mu \mathrm{L})$, activated $\mathrm{Zn} \quad(185 \mathrm{mg}, 2.92 \mathrm{mmol})$, aminodiphenylmethane (440 $\mu \mathrm{L}, 3.5 \mathrm{mmol}), \mathrm{NaCNBH}_{3}(137 \mathrm{mg}, 2.19 \mathrm{mmol})$, and $\mathrm{AcOH}(200 \mu \mathrm{L})$. The mixture was stirred at reflux for $18 \mathrm{~h}$ then cooled and the solvent was removed under reduced pressure. The product was dissolved in ethanol and dry loaded onto a short silica plug and eluted with $10 \%$ methanolic ethyl acetate in order to remove zinc and zinc salts. The resulting oil was used without further purification. ${ }^{1} \mathrm{H}$ NMR $\left(500 \mathrm{MHz}, \mathrm{CDCl}_{3}\right) 7.28(\mathrm{~m}, 10 \mathrm{H}, \mathrm{Ph}), 5.59$ $\left(\mathrm{ddd}, J_{3,4}=6.5, J_{4,5 \text {-cis }}=10.7, J_{4,5 \text {-trans }}=17.4 \mathrm{~Hz}, 1 \mathrm{H}, \mathrm{H}-4\right), 5.39\left(\mathrm{~s}, 1 \mathrm{H}, \mathrm{CHPh}_{2}\right)$, $5.11\left(\mathrm{~d}, J_{4,5-\text { trans }}=17.4 \mathrm{~Hz}, 1 \mathrm{H}, \mathrm{H}-5\right.$-trans $), 5.06\left(\mathrm{~d}, J_{4,5-\text {-cis }}=10.7 \mathrm{~Hz}, 1 \mathrm{H}, \mathrm{H}-5\right.$-cis $)$, $3.85\left(\mathrm{dd}, J_{2,3}=5.0, J_{3,4}=6.5 \mathrm{~Hz}, 1 \mathrm{H}, \mathrm{H}-3\right), 3.77\left(\mathrm{ddd}, J_{1 \mathrm{~b}, 2}=3.6, J_{2,3}=5.0, J_{1 \mathrm{a}, 2}=\right.$ $9.1 \mathrm{~Hz}, 1 \mathrm{H}, \mathrm{H}-2), 2.96\left(\mathrm{dd}, J_{1 \mathrm{~b}, 2}=3.6, J_{1 \mathrm{a}, 1 \mathrm{~b}}=13.3 \mathrm{~Hz}, 1 \mathrm{H}, \mathrm{H}-1 \mathrm{~b}\right), 2.90\left(\mathrm{dd}, J_{1 \mathrm{a}, 2}=\right.$ 9.1, $\left.J_{1 \mathrm{a}, 1 \mathrm{~b}}=13.3 \mathrm{~Hz}, 1 \mathrm{H}, \mathrm{H}-1 \mathrm{a}\right)$.<smiles>C=CC(O)C(O)CNC(F)(F)F</smiles>

(2S,3S)-1-Amino-pent-4-ene-2,3-diol trifluoroacetate (4). To a solution of $(2 S, 3 S)$-1-(diphenylmethyl)aminopent-4-ene-2,3-diol 3 (225 $\mathrm{mg}, 0.79 \mathrm{mmol})$ in TFA (5 $\mathrm{mL})$ triethylsilane $(232 \mu \mathrm{L}, 1.46 \mathrm{mmol})$ was added and the mixture stirred at reflux for $18 \mathrm{~h}$. The solution was cooled and the solvent removed under reduced pressure. The product was dissolved in water $(50 \mathrm{~mL})$ and washed with diethyl ether (three times $50 \mathrm{~mL}$ ). The water layer was then concentrated and purified by gradient flash chromatography (DCM/EtOH/MeOH/30\% aqueous $\mathrm{NH}_{3}, 5 / 2 / 2 / 1$, $\mathrm{v} / \mathrm{v} / \mathrm{v} / \mathrm{v})$ to give $4(93 \%$ from $2,158 \mathrm{mg}, 0.73 \mathrm{mmol})$ as the TFA salt. $\mathrm{R}_{f}=0.32$ $\left(\mathrm{DCM} / \mathrm{EtOH} / \mathrm{MeOH} / 30 \%\right.$ aqueous $\left.\mathrm{NH}_{3}, 5 / 2 / 2 / 1, \mathrm{v} / \mathrm{v} / \mathrm{v} / \mathrm{v}\right) ;[\alpha]_{\mathrm{D}}{ }^{20}=-25.5(c=$ 0.08, EtOH); IR (film) 3405, 3212, 2888, 1555, 1434, 1183, 1127, 1016, 838 
$\mathrm{cm}^{-1} .{ }^{1} \mathrm{H}$ NMR $\left(300 \mathrm{MHz}, \mathrm{D}_{2} \mathrm{O}\right) \delta 5.71\left(\mathrm{ddd}, J_{3,4}=6.4, J_{4,5 \text {-cis }}=10.4, J_{4,5 \text {-trans }}=\right.$ $17.1 \mathrm{~Hz}, 1 \mathrm{H}, \mathrm{H}-4), 5.34\left(\mathrm{~d}, J_{4,5-t r a n s}=17.1 \mathrm{~Hz}, 1 \mathrm{H}, \mathrm{H}-5\right.$-trans $), 5.28\left(\mathrm{~d}, J_{4,5-\text { cis }}=\right.$ $10.4 \mathrm{~Hz}, 1 \mathrm{H}, \mathrm{H}-5-c i s), 4.10\left(\mathrm{dd}, J_{2,3}=5.0, J_{3,4}=6.4 \mathrm{~Hz}, 1 \mathrm{H}, \mathrm{H}-3\right), 4.05(\mathrm{~s}, 1 \mathrm{H}$, $\mathrm{NH}), 3.81\left(\mathrm{ddd}, J_{1 \mathrm{a}, 2}=3.3, J_{2,3}=5.0, J_{1 \mathrm{~b}, 2}=9.7 \mathrm{~Hz}, 1 \mathrm{H}, \mathrm{H}-2\right), 3.15\left(\mathrm{dd}, J_{1 \mathrm{a}, 2}=3.3\right.$, $\left.J_{1 \mathrm{a}, 1 \mathrm{~b}}=13.2 \mathrm{~Hz}, 1 \mathrm{H}, \mathrm{H}-1 \mathrm{a}\right), 2.98\left(\mathrm{dd}, J_{1 \mathrm{~b}, 2}=9.7, J_{1 \mathrm{a}, 1 \mathrm{~b}}=13.2 \mathrm{~Hz}, 1 \mathrm{H}, \mathrm{H}-1 \mathrm{~b}\right) ;{ }^{13} \mathrm{C}$ NMR (75 MHz, D $2 \mathrm{O}) \delta 135.8$ (C4), 117.9 (C5), 73.9 (C3), 72.0 (C2), 42.0 (C1); HRMS(ESI) $m / z$ calcd. for $\left[\mathrm{C}_{5} \mathrm{H}_{11} \mathrm{O}_{2} \mathrm{~N}+\mathrm{H}\right]^{+}: 118.0863$, obsd.: 118.0871 .<smiles>C=CC(O)C(O)CN</smiles>

(2S,3S)-1-Amino-pent-4-ene-2,3-diol hydrochloride

(4). To a solution of iodopyranoside 2 (60.1 $\mathrm{mg}$, $0.22 \mathrm{mmol}$ ) in a saturated solution of $\mathrm{NH}_{4} \mathrm{OAc}$ in $\mathrm{EtOH}$ (4.4 mL) was added activated $\mathrm{Zn}(71.5 \mathrm{mg}, 1.1 \mathrm{mmol}), \mathrm{NaCNBH}_{3}(41 \mathrm{mg}$, $0.66 \mathrm{mmol})$ and $30 \%$ aqueous $\mathrm{NH}_{3}(1.8 \mathrm{~mL})$. The mixture was stirred at reflux for $18 \mathrm{~h}$, cooled to room temperature and concentrated under reduced pressure. The residue was redissolved in $i \mathrm{PrOH}$ and a solution of $20 \% \mathrm{HCl}$ in $i \mathrm{PrOH}$ was added (4.6 g, $27.5 \mathrm{mmol})$. The suspension was filtered through celite and concentrated under reduced pressure. The residue was redissolved in $i \mathrm{PrOH}(20 \mathrm{~mL})$ and filtered. The solution was dry loaded onto silica gel via the addition of silica gel to the dissolved material followed by evaporation of the solvent under reduced pressure. The silica gel was loaded onto a silica gel column and purified by gradient flash chromatography (DCM/EtOH/MeOH/30\% aqueous $\mathrm{NH}_{3}, 25 / 2 / 2 / 1$ to $5 / 2 / 2 / 1, \mathrm{v} / \mathrm{v} / \mathrm{v} / \mathrm{v})$ to give alkenylamine 4 as the $\mathrm{HCl}$ salt $(95 \%, 32 \mathrm{mg}$, $0.21 \mathrm{mmol}) . \mathrm{R}_{f}=0.37\left(\mathrm{DCM} / \mathrm{EtOH} / \mathrm{MeOH} / 30 \%\right.$ aqueous $\left.\mathrm{NH}_{3}, 5 / 2 / 2 / 1, \mathrm{v} / \mathrm{v} / \mathrm{v} / \mathrm{v}\right)$; $[\alpha]_{\mathrm{D}}^{20}=-40.0(c=0.07, \mathrm{EtOH})$; IR (film) 3405, 3212, 2888, 1555, 1434, 1016 $\mathrm{cm}^{-1} .{ }^{1} \mathrm{H}$ NMR $\left(300 \mathrm{MHz}, \mathrm{D}_{2} \mathrm{O}\right) \delta 5.71\left(\mathrm{ddd}, J_{3,4}=6.4, J_{4,5-c i s}=10.5, J_{4,5-\text { trans }}=\right.$ $17.1 \mathrm{~Hz}, 1 \mathrm{H}, \mathrm{H}-4), 5.34\left(\mathrm{~d}, J_{4,5-t r a n s}=17.1 \mathrm{~Hz}, 1 \mathrm{H}, \mathrm{H}-5\right.$-trans $), 5.28\left(\mathrm{~d}, J_{4,5-\text { cis }}=\right.$ $10.5 \mathrm{~Hz}, 1 \mathrm{H}, \mathrm{H}-5-c i s), 4.10\left(\mathrm{dd}, J_{2,3}=5.0, J_{3,4}=6.4 \mathrm{~Hz}, 1 \mathrm{H}, \mathrm{H}-3\right), 4.05(\mathrm{~s}, 1 \mathrm{H}$, $\mathrm{NH}), 3.81\left(\mathrm{ddd}, J_{1 \mathrm{a}, 2}=3.3, J_{2,3}=5.0, J_{1 \mathrm{~b}, 2}=9.7 \mathrm{~Hz}, 1 \mathrm{H}, \mathrm{H}-2\right), 3.15\left(\mathrm{dd}, J_{1 \mathrm{a}, 2}=3.3\right.$, $\left.J_{1 \mathrm{a}, 1 \mathrm{~b}}=13.2 \mathrm{~Hz}, 1 \mathrm{H}, \mathrm{H}-1 \mathrm{a}\right), 2.98\left(\mathrm{dd}, J_{1 \mathrm{~b}, 2}=9.7, J_{1 \mathrm{a}, 1 \mathrm{~b}}=13.2 \mathrm{~Hz}, 1 \mathrm{H}, \mathrm{H}-1 \mathrm{~b}\right) ;{ }^{13} \mathrm{C}$ NMR (75 MHz, D $2 \mathrm{O}) \delta 135.8$ (C4), 117.9 (C5), 73.9 (C3), 72.0 (C2), 42.0 (C1); HRMS(ESI) $m / z$ calcd. for $\left[\mathrm{C}_{5} \mathrm{H}_{11} \mathrm{O}_{2} \mathrm{~N}+\mathrm{H}\right]^{+}: 118.0863$, obsd.: 118.0871 .<smiles>C=CC(O)C(O)CNCC(O)C(O)C=C</smiles>

Dimer: $\quad(2 S, 3 S)-1-((2 S, 3 S)-2,3-D i h y d r o x y-p e n t-4-$ enylamino)-pent-4-ene-2,3-diol (14). $\quad \mathrm{R}_{f}=0.46$ 
(DCM/EtOH/MeOH/30\% aqueous $\left.\mathrm{NH}_{3}, 5 / 2 / 2 / 1, \mathrm{v} / \mathrm{v} / \mathrm{v} / \mathrm{v}\right) ;{ }^{1} \mathrm{H}$ NMR $(300 \mathrm{MHz}$, $\left.\mathrm{D}_{2} \mathrm{O}\right) \delta 5.86\left(\mathrm{ddd}, J_{3,4}=6.5, J_{4,5 \text {-cis }}=10.5, J_{4,5 \text {-trans }}=17.3 \mathrm{~Hz}, 2 \mathrm{H}, \mathrm{H}-4\right), 5.36(\mathrm{dt}$, $J_{4,5-\text { trans }}=17.3, J_{3,5-\text { trans }}=J_{5 \text {-cis,5-trans }}=1.3 \mathrm{~Hz}, 2 \mathrm{H}, \mathrm{H}$-5-trans), $5.30\left(\mathrm{dt}, J_{4,5-\text {-cis }}=\right.$ $10.5, J_{3,5-c i s}=J_{5 \text {-cis,5-trans }}=1.3 \mathrm{~Hz}, 2 \mathrm{H}, \mathrm{H}-5$-cis $), 4.10\left(\mathrm{ddt}, J_{2,3}=4.9, J_{3,4}=6.5, J_{3,5}\right.$ $\left.c_{\text {cis }}=J_{3,5 \text {-trans }}=1.3 \mathrm{~Hz}, 2 \mathrm{H}, \mathrm{H}-3\right), 3.91\left(\mathrm{ddd}, J_{1 \mathrm{a}, 2}=3.3, J_{2,3}=4.9, J_{1 \mathrm{~b}, 2}=9.7 \mathrm{~Hz}\right.$, $2 \mathrm{H}, \mathrm{H}-2), 3.21\left(\mathrm{dd}, J_{1 \mathrm{a}, 2}=3.3, J_{1 \mathrm{a}, 1 \mathrm{~b}}=13.0 \mathrm{~Hz}, 2 \mathrm{H}, \mathrm{H}-1 \mathrm{a}\right), 3.11\left(\mathrm{dd}, J_{1 \mathrm{~b}, 2}=9.7\right.$, $\left.J_{1 \mathrm{a}, 1 \mathrm{~b}}=13.0 \mathrm{~Hz}, 2 \mathrm{H}, \mathrm{H}-1 \mathrm{~b}\right) ;{ }^{13} \mathrm{C} \mathrm{NMR}\left(75 \mathrm{MHz}, \mathrm{D}_{2} \mathrm{O}\right) \delta 135.4$ (C4), 118.3 (C5), 73.7 (C3), 68.8 (C2), 49.5 (C1). HRMS(ESI) $\mathrm{m} / z$ calcd. for $\left[\mathrm{C}_{10} \mathrm{H}_{19} \mathrm{O}{ }_{4} \mathrm{~N}+\mathrm{H}\right]^{+}$: 218.1387, obsd.: 218.1386 .

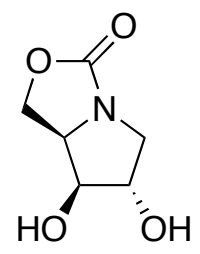

(6S,7S,7aR)-6,7-Dihydroxy-tetrahydro-pyrrolo[1,2-c]oxazol-3one (7). To a solution of alkenylamine hydrochloride 4 (41 $\mathrm{mg}, 0.35$ $\mathrm{mmol})$ in water $(1.75 \mathrm{~mL})$ was added $\mathrm{NaHCO}_{3}(44 \mathrm{mg}, 0.53 \mathrm{mmol})$ and $\mathrm{I}_{2}(109 \mathrm{mg}, 0.39 \mathrm{mmol})$. The solution was stirred for $18 \mathrm{~h}$ at room temperature then filtered and concentrated under reduced pressure. The product was purified by silica gel chromatography (EtOAc/MeOH, 95/5, v/v) to give carbamate 7 as an amorphous white powder $(99 \%, 55 \mathrm{mg}, 0.35 \mathrm{mmol}) .[\alpha]_{\mathrm{D}}{ }^{19}=-$ $26.1(c=0.4$, EtOH); IR (film) 3425, 3243, 3125, 1680, 1435, 1194, 1130, 844, $799,717 \mathrm{~cm}^{-1} .{ }^{1} \mathrm{H}$ NMR $\left(300 \mathrm{MHz}, \mathrm{D}_{2} \mathrm{O}\right) \delta 4.64\left(\mathrm{t}, J_{4,5 \mathrm{a}}=J_{5 \mathrm{a}, 5 \mathrm{~b}}=9.3 \mathrm{~Hz}, 1 \mathrm{H}, \mathrm{H}-\right.$ $5 \mathrm{a}), 4.51\left(\mathrm{dd}, J_{4,5 \mathrm{~b}}=3.7, J_{5 \mathrm{a}, 5 \mathrm{~b}}=9.3 \mathrm{~Hz}, 1 \mathrm{H}, \mathrm{H}-5 \mathrm{~b}\right), 4.40\left(\mathrm{~d}, J_{1 \mathrm{a}, 2}=5.3 \mathrm{~Hz}, 1 \mathrm{H}, \mathrm{H}-\right.$ 2), $4.31\left(\mathrm{dt}, J_{4,5 \mathrm{a}}=8.5, J_{4,5 \mathrm{~b}}=J_{3,4}=3.7 \mathrm{~Hz}, 1 \mathrm{H}, \mathrm{H}-4\right), 4.05\left(\mathrm{~d}, J_{3,4}=3.7 \mathrm{~Hz}, 1 \mathrm{H}\right.$, $\mathrm{H}-3), 3.80\left(\mathrm{dd}, J_{1 \mathrm{a}, 2}=5.3, J_{1 \mathrm{a}, 1 \mathrm{~b}}=12.6 \mathrm{~Hz}, 1 \mathrm{H}, \mathrm{H}-1 \mathrm{a}\right), 3.13\left(\mathrm{~d}, J_{1 \mathrm{a}, 1 \mathrm{~b}}=12.6 \mathrm{~Hz}\right.$, 1H, H-1b); ${ }^{13} \mathrm{C}$ NMR (75 MHz, D $\left.2 \mathrm{O}\right) \delta 164.4$ (C6), 76.5 (C2), 74.3 (C3), 64.0 (C5), $62.0(\mathrm{C} 4), 52.2(\mathrm{C} 1)$; HRMS(ESI) $m / z$ calcd. for $\left[\mathrm{C}_{6} \mathrm{H}_{9} \mathrm{O}_{4} \mathrm{~N}+\mathrm{H}\right]^{+}:$160.0604, obsd.: 160.0605 .

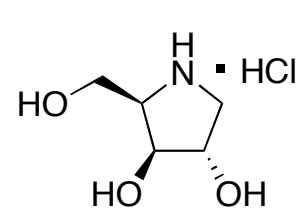

1,4-Dideoxy-1,4-imino-D-xylitol hydrochloride (8). To a solution of carbamate $7(6.5 \mathrm{mg}, 41 \mu \mathrm{mol})$ in $\mathrm{EtOH}(1 \mathrm{~mL})$ was added $\mathrm{NaOH}(16.4 \mathrm{mg}, 0.41 \mathrm{mmol})$. The solution was stirred at reflux for $2 \mathrm{~h}$ then cooled and purified directly using Dowex $\left(\mathrm{H}^{+}\right)$. Product 8 was eluted in 5 to $15 \%$ aqueous $\mathrm{NH}_{3}$, concentrated in vacuo and converted to the $\mathrm{HCl}$ salt $(99 \%, 7.0 \mathrm{mg}, \quad 41 \mu \mathrm{mol}) . \quad \mathrm{R}_{f}=0.9$ (DCM/EtOH/MeOH/30\% aqueous $\left.\mathrm{NH}_{3}, 5 / 2 / 2 / 1, \mathrm{v} / \mathrm{v} / \mathrm{v} / \mathrm{v}\right) ;[\alpha]_{\mathrm{D}}{ }^{20}=+6.4(c=0.5$, 
$\mathrm{H}_{2} \mathrm{O}$ ); IR (film) 3334, 3172, 2974, 2886, 1380, 1328, 1088, $1045 \mathrm{~cm}^{-1} .{ }^{1} \mathrm{H}$ NMR $\left(300 \mathrm{MHz}, \mathrm{D}_{2} \mathrm{O}\right) \delta 4.37$ (d, $\left.J_{1 \mathrm{a}, 2}=4.4 \mathrm{~Hz}, 1 \mathrm{H}, \mathrm{H}-2\right), 4.30$ (s, 1H, H-3), 4.01 (m, $1 \mathrm{H}, \mathrm{H}-5 \mathrm{a}), 3.88\left(\mathrm{~m}, 2 \mathrm{H}, \mathrm{H}-4\right.$ and H-5b), $3.64\left(\mathrm{dd}, J_{1 \mathrm{a}, 2}=4.4, J_{1 \mathrm{a}, 1 \mathrm{~b}}=13.0 \mathrm{~Hz}, 1 \mathrm{H}\right.$, $\mathrm{H}-1 \mathrm{a}), 3.28\left(\mathrm{~d}, J_{1 \mathrm{a}, 1 \mathrm{~b}}=13.0 \mathrm{~Hz}, 1 \mathrm{H}, \mathrm{H}-1 \mathrm{~b}\right) ;{ }^{13} \mathrm{C} \mathrm{NMR}\left(75 \mathrm{MHz}, \mathrm{D}_{2} \mathrm{O}\right) \delta 74.3,74.2$ (C2, C3), 62.9 (C4), 57.2 (C5), 50.4 (C1). HRMS(ESI) $\mathrm{m} / z$ calcd. for $\left[\mathrm{C}_{5} \mathrm{H}_{11} \mathrm{O}_{3} \mathrm{~N}+\mathrm{H}\right]^{+}:$134.0812, obsd.: 134.0818 . 


\subsection{References}

(1) Dangerfield, E. M.; Timmer, M. S. M.; Stocker, B. L. Org. Lett. 2009, 11, 535-538.

(2) Asano, N.; Nash, R. J.; Molyneux, R. J.; Fleet, G. W. Tetrahedron: Asymmetry 2000, 11, 1645-1680.

(3) Watson, A. A.; Fleet, G. W. J.; Asano, N.; Molyneux, R. J.; Nash, R. J. Phytochemistry 2001, 56, 265-295.

(4) Miniami, Y.; Kuriyama, C.; Ikeda, K.; Kato, A.; Takebayashi, K.; Adachi, I.; Fleet, G. W.; Kettawan, A.; Okamoto, T.; Asano, N. Bioorg. Med. Chem. 2008, 16, 2734-3740.

(5) Furukawa, J.; Okuda, S.; Saito, K.; Hatanaka, S.-I. Phytochemistry 1985, 24, 593-594.

(6) Asano, N.; Yasuda, K.; Kizu, H.; Kato, A.; Fan, J.-Q.; Nash, R. J.; Fleet, G. W. J.; Molyneux, R. J. Eur. J. Biochem. 2001, 268, 35-41.

(7) Saludes, J. P.; Lievens, S. C.; Molinski, T. F. J. Nat. Prod. 2007, 70, 436-438.

(8) Ikota, N. Chem. Pharm. Bull. 1989, 37, 3399-3402.

(9) Ghavami, A.; Johnston, B. D.; Maddess, M. D.; Chinapoo, S. M.; Jensen, M. T.; Svensson, B.; Pinto, B. M. Can. J. Chem. 2002, 80, 937-942.

(10) Nakata, M.; Tamai, T.; Kamio, T.; Kinoshita, M.; Tatsuta, K. Tetrahedron Lett. 1994, 35, 3099-3102.

(11) van der Klein, P. A. M.; Filemon, W.; Broxterman, H. J. G.; van der Marel, G. A.; van Boom, J. H. Synthetic Commun. 1992, 22, 1763-1771.

(12) Skaanderup, P. R.; Poulsen, C. S.; Hyldtoft, L.; Jørgensen, M. R.; Madsen, R. Synthesis 2002, 12, 1721-1727.

(13) Verhelst, S. H. L.; Martinez, B. P.; Timmer, M. S. M.; Lodder, G.; Van der Marel, G. A.; Overkleeft, H. S.; Van Boom, J. H. J. Org. Chem. 2003, 68, 9598-9603.

(14) Chamberlin, A. R.; Dezube, M.; Dussault, P.; McMills, M. C. J. Am. Chem. Soc. 1983, 105, 5819-5825.

(15) Chamberlin, A. R.; Mulholland Jr, R. L.; Kahn, S. D.; Hehre, W. J. J. Am. Chem. Soc. 1987, 109, 672-677.

(16) Timmer, M. S. M.; Verhelst, S. H.; Grotenbreg, G. M.; Overhand, M.; Overkleeft, H. S. Pure Appl. Chem. 2005, 77, 1173-1181.

(17) Huang, Y.; Dalton, D. R.; Carroll, P. J. J. Org. Chem. 1997, 62, 372-376. 



\section{Chapter 5: Reductive Amination Methodology for the Synthesis of Primary Amines ${ }^{1}$}

\subsection{Introduction}

Amines are an important class of compounds and are found in many natural products, pharmaceuticals and other valuable organic molecules including dyes and agrochemicals. ${ }^{2,3}$ There are many synthetic transformations that can be used to prepare amines, ${ }^{2}$ however methodology for the selective production of primary amines is more limited. Of these, reductive aminations are particularly important and well utilised for the synthesis of primary amines.-6 These reactions often utilise molecular hydrogen as the imine reducing agent ${ }^{5}$ with ruthenium in particular proving to be an efficient and selective catalyst. ${ }^{6,7}$ Though this methodology has significant merit, the use of hydrogen gas under high pressure and temperature nonetheless limits functional group compatibility as double bonds are reduced and aromatic groups removed under these conditions. To circumvent this problem, metal hydride reducing agents can be employed, however, methodology for selectively forming primary amines via metal hydride reductive amination is limited (as discussed in 1.3).

In chapter 4, a procedure for the preparation of primary amines from methyl glycosides using a Vasella reductive amination reaction, that did not require the use of protecting groups was highlighted. ${ }^{8}$ For this methodology to have wider applicability the scope and limitations of this novel reductive amination protocol need to be explored. The results of such studies and insight into factors that may be responsible for the observed chemoselectivity of the reductive amination methodology are reported herein. More specifically, we wanted to understand the 
influence that the free hydroxyl substituents had on the chemoselectivity of the reaction and whether the reductive amination conditions gave similar results when starting with preformed aldehydes (i.e. without the Vasella component of the reaction).

\subsection{Results and Discussion}

\section{Vasella Reductive Amination}

Given the importance of primary amines as synthetic products and intermediates, we were interested in developing new methodology for the preparation of amines from aldehydes without the need for protecting groups. In our protecting group free synthesis of amines (Chapter 4), a Vasella reaction ${ }^{9}$ and a reductive amination were used to prepare linear alkenylamines (I) in one step from an alkyl halo-glycoside precursor (II), itself readily available from the parent monosaccharide (III) in two steps $^{10}$ (Scheme 5.1). Here, the typical Vasella reductive amination protocol ${ }^{8}$ involved the overnight reflux of a suspension of $\mathrm{Zn}$, $\mathrm{NH}_{4} \mathrm{OAc}$ (excess), $\mathrm{NH}_{3}, \mathrm{NaCNBH}_{3}$ and the iodosugar in ethanol. Under these conditions the primary mono-alkylamine was produced exclusively ( $>20: 1$ primary:secondary). Excess $\mathrm{NH}_{4} \mathrm{OAc}$ was crucial to selectively obtain the primary amine.

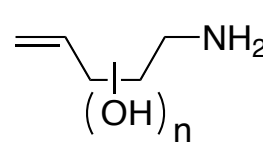

I

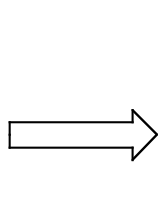

II

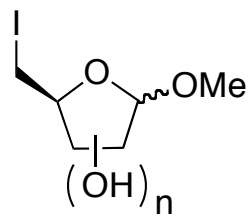

II

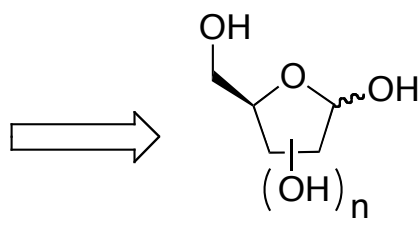

III

Scheme 5.1. Retrosynthesis of primary alkenylamines.

To investigate the applicability of this reaction to other methyl iodosugar or aldehyde substrates, we wanted to first develop a more efficient strategy for the isolation of the amines from the excess $\mathrm{NH}_{4} \mathrm{OAc}$. In chapter 4 excess salts were precipitated, by converting $\mathrm{NH}_{4} \mathrm{OAc}$ to $\mathrm{NH}_{4} \mathrm{Cl}$ and $\mathrm{AcOH}$. This process requires $\mathrm{HCl}$ in iso-propanol and not all amine products are stable under these conditions. In addition, this method usually leaves a small quantity of residual $\mathrm{NH}_{4} \mathrm{Cl}$, which is subsequently removed by silica gel column chromatography. To improve the isolation of the amine products we investigated Dowex $-\mathrm{H}^{+}$ion exchange chromatography as a means to remove the excess salts. Indeed, this methodology 
proved the most suitable for isolating the amine products from the reaction mixture. With greater affinity for the ion exchange resin than the ammonium salts, the alkylamine was readily separated by loading the reaction mixture directly onto the ion exchange resin and first washing the column with water (to remove the salts), then eluting the amine product with aqueous ammonia.

Having developed an improved strategy for the isolation of amines from the ammonium salts, we commenced our investigations into the factors responsible for primary amine selectivity. To explore the influence of $\mathrm{pH}$ on the chemoselectivity, we conducted the Vasella reductive amination over a range of $\mathrm{pH}$ conditions using methyl iodoglycoside $\mathbf{1}$ as a model substrate, and recorded the resulting primary to secondary amine ratio (Table 5.1). A neutral solution, obtained by the addition of $\mathrm{AcOH}$ (10 eq.), gave the dimeric secondary amine as the major product $(4.5: 5.5,2: 3$, Entry 1, Table 5.1). At a $\mathrm{pH}$ of 8 , when a saturated solution of $\mathrm{NH}_{4} \mathrm{OAc}$ was used without the addition of either $\mathrm{AcOH}$ or $\mathrm{NH}_{3}$, formation of primary amine 2 was favoured (Entry 2). Increasing the $\mathrm{pH}$ of the reaction mixture to 10 using $\mathrm{NH}_{3}$ (10 eq.) improved the selectivity even further (4:1, 2:3, Entry 3). Having observed the beneficial influence that increasing the $\mathrm{pH}$ has on chemoselectivity, 60 eq. of $\mathrm{NH}_{3}$ was then added. Under these conditions the primary amine was the only product observed by NMR $(>20: 1,2: 3$, Entry 4). It is proposed that this $\mathrm{pH}$ dependant selectivity relates to the beneficial influence of increasing the availability of ammonia. At neutral or acidic $\mathrm{pH}$ a greater proportion of ammonia will be protonated forming the ammonium cation, which will not act as an amine source. As the $\mathrm{pH}$ increases, however, the availability of ammonia increases favouring primary imine formation, and therefore formation of the primary amine. Here it is also important to note that though primary amine $\mathbf{2}$ is more nucleophilic than ammonia, it is also more basic. Therefore, while it is important to have $\mathrm{NH}_{3}$ available to react, the correct balance of free ammonia to amine product may also be critical in optimising the formation of primary amine. At the optimum $\mathrm{pH}$ it maybe possible to protonate primary amine $\mathbf{2}$, preventing it from reacting further to give secondary amine $\mathbf{3}$, whilst a proportion of the ammonia remains unprotonated and can act effectively as a nucleophile. 
Table 5.1. Vasella reductive amination under different $\mathrm{pH}$ conditions.

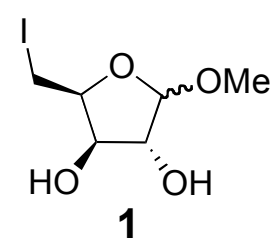

Entry

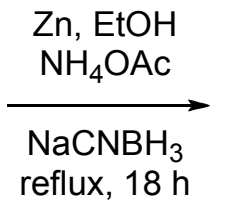

reflux, $18 \mathrm{~h}$<smiles>C=CC(O)C(O)CN</smiles>

2<smiles>C=C[C@H](O)[C@@H](O)CNC[C@H](O)[C@H](O)C=C</smiles>

3

Conditions

pH of the

Ratio $^{\mathrm{b}}$

reaction mixture ${ }^{\mathrm{a}}$

\begin{tabular}{clcc}
\hline 1 & $\mathrm{NH}_{4} \mathrm{OAc}$ (sat.), $\mathrm{AcOH}$ (10 eq.) & 7 & $4.5: 5.5$ \\
2 & $\mathrm{NH}_{4} \mathrm{OAc}$ (sat.) & 8 & $3: 2$ \\
3 & $\mathrm{NH}_{4} \mathrm{OAc}$ (sat.), $\mathrm{NH}_{3}$ (10 eq.) & 10 & $4: 1$ \\
4 & $\mathrm{NH}_{4} \mathrm{OAc}$ (sat.), $\mathrm{NH}_{3}$ (60 eq.) & 12 & $>20: 1$
\end{tabular}

${ }^{\mathrm{a}} \mathrm{pH}$ of the reaction mixture after all reagents have been added, at the start of the reaction

${ }^{\mathrm{b}}$ Ratio obtained from NMR of the crude material

Using our optimised conditions, we investigated the scope of the Vasella reductive amination reaction conditions for the synthesis of primary amines from other methyl iodoglycosides. Using these conditions alkenylamines $\mathbf{2}$ and $\mathbf{5}$ (Entries 1 and 2, Table 5.2) were synthesised chemoselectively, and in excellent yields of $95 \%$ and $91 \%$, respectively. Reaction of D-arabinoside 6 (Entry 3, Table 5.2) also proceeded uneventfully to give the corresponding alkenylamine 7 in excellent yield (93\%). As anticipated, the stereochemistry around the furanose ring had no significant effect on the yield or selectivity of the reaction. Although by-products from Vasella reactions have been well documented, with reductive dehalogenation and the reduction of the aldehyde to the alcohol being the most common degradation products, ${ }^{11}$ this Vasella reductive amination occurred smoothly and with no other products observed. To further investigate the applicability of our reaction conditions, 2-deoxy-riboside $\mathbf{8}$ was subjected to the same reductive amination protocol (Entry 4, Table 5.2). Again, exclusive formation of the primary alkenylamine was observed, with alkenylamine 9 being isolated in good yield (81\%). This result indicated that the absence of an $\alpha$ hydroxyl function in the aldehyde substrate did not adversely affect the efficiency or selectivity of the reaction. 
Table 5.2. Vasella reductive amination of methyl iodoglycosides.

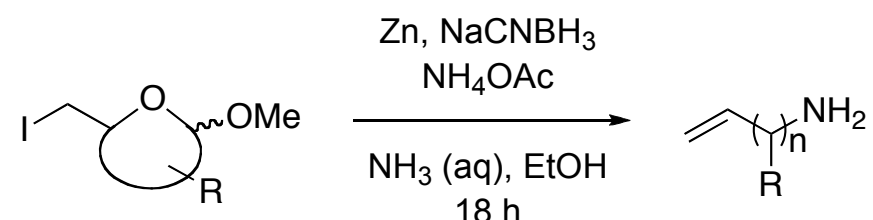

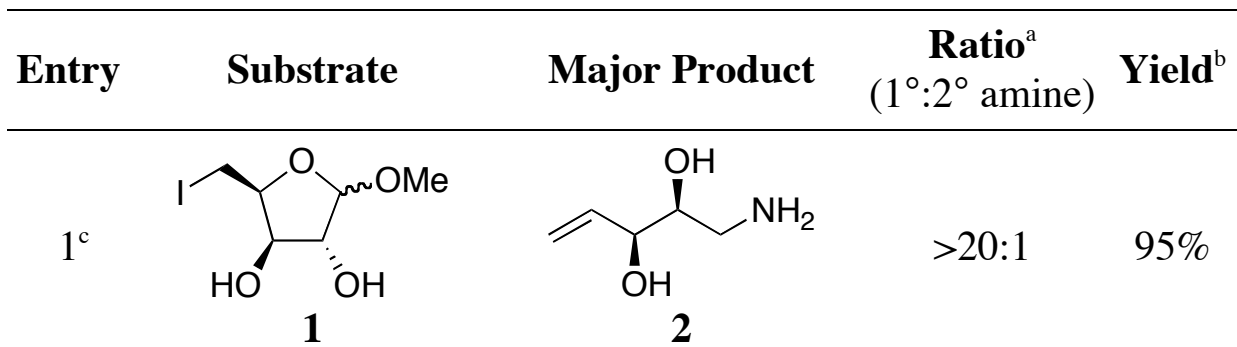

2<smiles>CO[C@@H]1OC(CI)[C@H](O)[C@H]1O</smiles>

4

3<smiles>CO[C@@H]1OC(CI)[C@@H](O)[C@H]1O</smiles>

4<smiles>CO[C@@H]1C[C@@H](CI)[C@@H](CI)O1</smiles>

8<smiles>CO[C@H]1OC(CI)[C@@H](O)[C@H]1OCc1ccccc1</smiles>

10<smiles>CO[C@H]1OC(CI)[C@@H](OCc2ccccc2)[C@H]1Cc1ccccc1</smiles>

12<smiles>CO[C@H]1OC(CI)[C@@H](O)[C@H](O)[C@H]1O</smiles>

14<smiles>C=C[C@H](O)[C@@H](O)CN</smiles><smiles>C=C[C@H](O)[C@@H](O)CN</smiles><smiles>C=C[C@H](O)CCN</smiles>

9<smiles>C=C[C@H](OCc1ccccc1)[C@@H](CN)Cc1ccccc1</smiles>

$3: 1 \quad 81 \%$

11<smiles>C=CC(OCc1ccccc1)[C@@H](CN)Cc1ccccc1</smiles>

$2: 1 \quad 98 \%$

13

$9: 1$ $93 \%$

15

${ }^{\text {a }}$ Ratio obtained from NMR of the crude material

${ }^{\mathrm{b}}$ Combined yield of primary and secondary amines following purification

${ }^{\mathrm{c}}$ See ref. 23

${ }^{\mathrm{d}}$ See Table 3 
We then explored the role that the functional group pattern has on the chemoselectivity of the reaction. The fully protected methyl iodoglycosides of Darabinose $\mathbf{1 0}^{12}$ and D-ribose $\mathbf{1 2}^{10}$ (Entries 5 and 6) were subjected to the Vasella reductive amination conditions. In both instances, the primary amines were the major products, although the secondary amine products were also observed. Following Dowex- $\mathrm{H}^{+}$ion exchange chromatography, the relative integrals of the corresponding ${ }^{1} \mathrm{H}$ NMR signals were used to determine the ratio of primary:secondary amine, and the assignments confirmed after separation of the two amine products via silica gel chromatography (DCM $\rightarrow$ $\mathrm{DCM} / \mathrm{EtOH} / \mathrm{MeOH} / 30 \%$ aq. $\left.\mathrm{NH}_{3}, 5 / 2 / 2 / 1, \mathrm{v} / \mathrm{v} / \mathrm{v} / \mathrm{v}\right)$. HRMS allowed for the identification of each product, as did the HMBC correlations between the $\mathrm{CH}_{2}-1$ and the $\mathrm{CH}_{2}-1^{\prime}$ for the secondary amine product. Here, it is interesting to note that the $\delta$ of C-1 of primary alkenylamines $\mathbf{1 1}(\delta=42.3 \mathrm{ppm})$ and $\mathbf{1 3}(\delta=42.5 \mathrm{ppm})$ was lower than the corresponding $\delta$ of $\mathrm{C}-1$ for the secondary amine product by $c a$. $8 \mathrm{ppm}$. This observation was consistent for all primary and secondary amines formed and provided a convenient means by which to readily distinguish the two products. The reduced selectivity observed for $\mathbf{1 0}$ and $\mathbf{1 2}$ suggested that the functional group pattern of the substrate could affect the chemoselectivity, though not as adversely as decreasing the $\mathrm{pH}$ of the reaction solution (Table 2).

Next, we turned our attention to the Vasella reductive amination of methyl 6-iodoglucoside 14 (Entry 7, Table 5.2) to determine if the methodology was applicable to pyranoside sugars. Using the standard reaction concentration, the selectivity for primary amine 15 was moderate $(9: 1,15: 16$, Entry 1, Table 5.3) and the overall yield was $93 \%$. In an attempt to improve primary amine formation the reaction was conducted in more dilute conditions $\left(40 \mathrm{~mL}\right.$ sat. $\mathrm{NH}_{4} \mathrm{OAc}$ in ethanol with 16 $\mathrm{mL} \mathrm{30 \%} \mathrm{aqueous} \mathrm{NH}_{3}$ per mmol). Using these conditions only the desired primary amine 15 was produced (Entry 2), however the yield was poor (50\%) due to a significant amount of degradation. Unfortunately, characterisation of the byproducts proved futile. To further study the effect that concentration had on the reaction outcome, more concentrated conditions $\left(5 \mathrm{~mL}\right.$ sat. $\mathrm{NH}_{4} \mathrm{OAc}$ in ethanol with $2 \mathrm{~mL} \mathrm{30 \%}$ aqueous $\mathrm{NH}_{3}$ per mmol) were used (Entry 3). These conditions led to a reduction in chemoselectivity, producing a 1:1 ratio of primary:secondary 
amine (15:16), though the overall yield was significantly improved with no observed degradation. From these results, it is apparent that over-dilution of the reaction mixture leads to increased degradation and poor yields, presumably as a consequence of a reduced rate of imine reduction, resulting in imine degradation.

Table 5.3. Vasella reductive amination at different reaction concentrations.<smiles>C=C[C@H](O)[C@H](O)[C@H](O)CNC[C@H](O)[C@H](O)[C@H](O)[C@H](O)C=C</smiles>
14

15 16

\begin{tabular}{cccc}
\hline Entry & Concentration & $\begin{array}{c}\text { Ratio } \\
(\mathbf{1 5 : 1 6})\end{array}$ & Yield \\
& & $9: 1$ & $93 \%$ \\
\hline 1 & $20 \mathrm{~mL}$ sat. $\mathrm{NH}_{4} \mathrm{OAc}$ in ethanol per mmol & $50 \%$ \\
2 & $40 \mathrm{~mL}$ sat. $\mathrm{NH}_{4} \mathrm{OAc}$ in ethanol per mmol & $>20: 1$ & $99 \%$ \\
3 & $5 \mathrm{~mL}$ sat. $\mathrm{NH}_{4} \mathrm{OAc}$ in ethanol per mmol & $1: 1$ & \\
\hline
\end{tabular}

${ }^{\mathrm{a}}$ Ratio obtained from NMR of the crude material

${ }^{\mathrm{b}}$ Combined yield of primary and secondary amines following purification

\section{Reductive Amination of Aldehydes}

Following our investigations into the Vasella reductive amination methodology, we explored the direct reductive amination of several aldehydes to determine whether the Vasella step was a requirement for good selectivity. To directly assess the effect of the initial Vasella reaction on the chemoselectivity, the benzyl protected aldehyde 17 was pre-formed by subjecting methyl iodoglycoside 12 to a Vasella reaction, followed by standard work-up procedures. Aldehyde $\mathbf{1 7}$ was then subjected to the reductive amination conditions to give $\mathbf{1 3}$ in a 1:1 ratio (primary:secondary amine) in a 97\% yield (Entry 1, Table 5.4). Though modest chemoselectivity was obtained, this result was nevertheless encouraging as it paralleled those observed during the Vasella reductive amination of arabinoside 10 and riboside 12 (Entries 5 and 6, Table 5.2) and suggests that the Vasella reaction has little effect on the chemoselectivity of the reductive amination. We then sought to investigate the reductive amination of unfunctionalised aldehydes. 
Here, nonanal (18) was subject to the reductive amination conditions and primary amine 19 was formed exclusively and in an excellent 98\% yield (Entry 2, Table 5.4). This result was significant for it illustrated that hydroxyl substituents were not required for the selective reductive amination of aldehydes and therefore markedly increased the scope of the reductive amination methodology. These results also indicated that the addition of zinc (for the one pot Vasella reductive amination reaction) did not significantly alter the outcome of the reaction and negates the possibility of boron ester $^{13,14}$ or zinc chelation ${ }^{15,16}$ aiding the chemoselectivity of the reaction. Unfortunately, the unprotected aldehyde products from the Vasella reaction of furanosides 1, 4 and 6 readily polymerised into mixtures of acetals and could not be isolated or studied in a reductive amination reaction that was independent of the Vasella reaction. 
Table 5.4. Reductive amination of masked aldehyde (hemi-acetal) and aldehyde substrates.

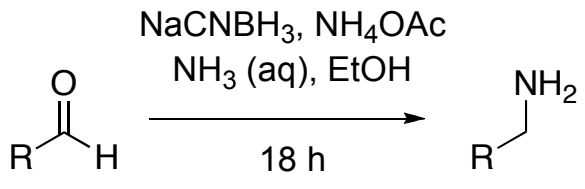

Entry

${ }^{a}$ Ratio obtained from NMR of the crude material.

${ }^{\mathrm{b}}$ Combined yield of primary and secondary amines following purification. 
We then examined the furanose series of hemiacetals 20, 22, and $\mathbf{2 4}$ (Entries 3 to 5, Table 5.4). Reductive amination of D-xylose (20) and 2-deoxy-D-ribose (22) gave the corresponding primary amines, $\mathbf{2 1}$ and $\mathbf{2 3}$, in excellent selectivity and in good yield (>85\%). These results parallel those for the furanose Vasella reductive amination series ( $c f$. Entries 1-4, Table 5.2) and expand the scope of the reaction to hemiacetals. To investigate the influence that the hydroxylation pattern has on the chemoselectivity, unsubstituted furanoside $\mathbf{2 4}$ was then subjected to the reductive amination conditions (Entry 5, Table 5.4). Here, the ratio of primary:secondary amine was also good (11:1), although the yield for the reaction was reduced (60\%). Amine 25 and its dimer were the only products observed suggesting that the reduced yield for this reaction was due to the formation of non-amine by-products, which could not be extracted from the salts using a Dowex- $\mathrm{H}^{+}$column.

The reductive amination of a series of pyranoses was then explored. First, Dglucose (26) was treated with a saturated solution of $\mathrm{NH}_{4} \mathrm{OAc}$ in ethanol, aqueous ammonia, and $\mathrm{NaCNBH}_{3}$ to give 1-amino-1-deoxy-D-glucitol (27) in good yield $(87 \%)$ and with excellent selectivity ( $>20: 1$, primary:secondary amine) (Entry 6, Table 5.4). Hemiacetals with decreasing hydroxylation were then subjected to the reductive amination reaction. Hydroxymethylpyranose 28 (Entry 7) provided the corresponding amine 29 with good selectivity (8:1), albeit in moderate yield $(65 \%)$, and the absence of the hydroxymethyl group (30, Entry 8) did not significantly alter the monomer to dimer ratio (7:1) with the primary amine $\mathbf{3 1}$ being produced in good yield (71\%). Though mixtures of primary and secondary amines were formed, these could be separated by flash column chromatography on silica gel. Again, by comparing the $\delta$ of C-5 of the primary and secondary amine products, the two products could be easily identified by ${ }^{13} \mathrm{C}$ NMR [e.g. C-5 of 5-amino-pentanol 31 had an upfield ${ }^{13} \mathrm{C}$ NMR chemical shift $(\delta=39.4 \mathrm{ppm})$, as compared to the C-5 of the secondary amine by-product $(\delta=47.7 \mathrm{ppm})]$. HMBC correlations and HRMS were also used to confirm the identity of the primary and secondary amines. Taken as a whole, these results demonstrate that our methodology is applicable to the synthesis of a variety of primary amines from 
different aldehyde precursors, and in almost all instances, good chemoselectivity was observed.

\subsection{Conclusion}

We have demonstrated that primary amines can be selectively produced from aldehydes via metal hydride reductive amination without the need for protecting groups. The most important influences on the chemoselectivity are $\mathrm{pH}$, the number of amine equivalents, and reaction concentration. The most ideal conditions are a $\mathrm{pH}$ of approximately 12, a large excess of ammonia, and a concentration of $20 \mathrm{~mL}$ of saturated $\mathrm{NH}_{4} \mathrm{OAc}$ in ethanol per mmol of aldehyde. Overall, the reductive amination methodology is applicable to a wide range of functionalised substrates and the yields of the primary amines are typically good. Without requiring the need for protecting groups, the methodology is fast, efficient and thus atom-economic, and provides a valuable synthetic tool for the selective formation of primary amines. The application of this methodology in the protecting group free synthesis of further azasugars is presented in chapter 6 .

\subsection{Experimental}

\section{General experimental}

Unless otherwise stated all reactions were performed under atmospheric air. Hemiacetals 24, 28 and 30 were synthesised according to the procedure by Tamaru and co-workers. ${ }^{17}$ Methyl iodoglycosides were synthesised according to the procedure by Madsen and co-workers. ${ }^{10}$ The $\mathrm{Zn}$ dust was activated by the careful addition of conc. $\mathrm{H}_{2} \mathrm{SO}_{4}$, followed by decantation and washing with EtOH (three times) and hexanes (three times), and storage under dry hexanes. All solvents were removed by evaporation under reduced pressure. Reactions were monitored by TLC-analysis on silica gel coated plastic sheets $(0.20 \mathrm{~mm}$, Polygram SIL G/UV 254 ) with detection by spraying with $20 \% \mathrm{H}_{2} \mathrm{SO}_{4}$ in EtOH followed by charring at $\sim 150{ }^{\circ} \mathrm{C}$, by dipping in $\mathrm{I}_{2}$ in silica, or by spraying with a solution of ninhydrin in EtOH followed by charring at $\sim 150{ }^{\circ} \mathrm{C}$. Column chromatography was performed on silica gel (40-63 micron). Dowex ${ }^{\circledR}$ W50-X8 acidic resin was used for ion exchange chromatography. High-resolution mass 
spectra were recorded on a Waters Q-TOF Premier ${ }^{\mathrm{TM}}$ Tandem Mass Spectrometer using positive electro-spray ionisation. Optical rotations were recorded using a Perkin-Elmer 241 polarimeter at the sodium D-line. Infrared spectra were recorded as thin films using a Bruker Tensor 27 FTIR spectrometer, equipped with an Attenuated Total Reflectance (ATR) sampling accessory, and are reported in wave numbers $\left(\mathrm{cm}^{-1}\right)$. Nuclear magnetic resonance spectra were recorded at 20 ${ }^{\circ} \mathrm{C}$ in $\mathrm{D}_{2} \mathrm{O}$ or $\mathrm{CDCl}_{3}$ using either a Varian Unity-INOVA operating at $300 \mathrm{MHz}$ or a Varian Unity operating at $500 \mathrm{MHz}$. Chemical shifts are given in ppm $(\delta)$ relative to tetramethylsilane. NMR peak assignments were made using COSY, HSQC and HMBC experiments.

General procedure for the synthesis of alkenylamines. To a solution of methyl iodo-glycoside $(1 \mathrm{mmol})$ in a saturated solution of $\mathrm{NH}_{4} \mathrm{OAc}$ in $\mathrm{EtOH}(20 \mathrm{~mL})$ was added activated $\mathrm{Zn}(327 \mathrm{mg}, 5 \mathrm{mmol}), \mathrm{NaCNBH}_{3}(188 \mathrm{mg}, 3 \mathrm{mmol})$ and $30 \%$ aqueous $\mathrm{NH}_{3}(8 \mathrm{~mL})$. The mixture was stirred at reflux for $18 \mathrm{~h}$, cooled to room temperature and concentrated under reduced pressure. The residue was redissolved in $\mathrm{H}_{2} \mathrm{O}$, loaded on to a Dowex $\mathrm{H}^{+}$ion exchange resin, and washed several times with $\mathrm{H}_{2} \mathrm{O}$ to remove excess salt. The amine product was then eluted with 15 to $30 \%$ aqueous $\mathrm{NH}_{3}$. Further purification was achieved using gradient flash chromatography (DCM/EtOH/MeOH/30\% aqueous $\mathrm{NH}_{3}, 25 / 2 / 2 / 1$ to $5 / 2 / 2 / 1, \mathrm{v} / \mathrm{v} / \mathrm{v} / \mathrm{v})$. The alkenylamines were converted to the $\mathrm{HCl}$ salts for characterization by the addition of two drops of $1 \mathrm{M} \mathrm{HCl}$ followed by concentration under reduced pressure.<smiles>C=CC(O)C(O)CN</smiles>

(2S,3S)-1-Amino-pent-4-ene-2,3-diol hydrochloride (2). By subjecting xyloside $1(60.1 \mathrm{mg}, 0.22 \mathrm{mmol})$ to the general procedure for the synthesis of alkenylamines, alkenylamine 2 was obtained as the $\mathrm{HCl}$ salt (32 mg, $0.21 \mathrm{mmol}, 95 \%) . \mathrm{R}_{f}=0.37\left(\mathrm{DCM} / \mathrm{EtOH} / \mathrm{MeOH} / 30 \%\right.$ aqueous $\mathrm{NH}_{3}, 5 / 2 / 2 / 1$, $\mathrm{v} / \mathrm{v} / \mathrm{v} / \mathrm{v}) ;[\alpha]_{\mathrm{D}}{ }^{20}=-40.0(c=0.07, \mathrm{EtOH}) ;$ IR $($ film) $3405,3212,2888,1555,1434$, $1016 \mathrm{~cm}^{-1} .{ }^{1} \mathrm{H}$ NMR $\left(300 \mathrm{MHz}, \mathrm{D}_{2} \mathrm{O}\right) \delta 5.71\left(\mathrm{ddd}, J_{3,4}=6.4, J_{4,5-c i s}=10.5 \mathrm{~Hz}, J_{4,5}\right.$ trans $=17.1 \mathrm{~Hz}, 1 \mathrm{H}, \mathrm{H}-4), 5.34$ (d, $J_{4,5-\text { trans }}=17.1 \mathrm{~Hz}, 1 \mathrm{H}, \mathrm{H}-5$-trans $), 5.28$ (d, $J_{4,5}$ $\left.c_{i s}=10.5 \mathrm{~Hz}, 1 \mathrm{H}, \mathrm{H}-5-c i s\right), 4.10\left(\mathrm{dd}, J_{2,3}=5.0, J_{3,4}=6.4 \mathrm{~Hz}, 1 \mathrm{H}, \mathrm{H}-3\right), 4.05(\mathrm{~s}$, 
$1 \mathrm{H}, \mathrm{NH}), 3.81\left(\mathrm{ddd}, J_{1 \mathrm{a}, 2}=3.3, J_{2,3}=5.0, J_{1 \mathrm{~b}, 2}=9.7 \mathrm{~Hz}, 1 \mathrm{H}, \mathrm{H}-2\right), 3.15\left(\mathrm{dd}, J_{1 \mathrm{a}, 2}=\right.$ $\left.3.3, J_{1 \mathrm{a}, 1 \mathrm{~b}}=13.2 \mathrm{~Hz}, 1 \mathrm{H}, \mathrm{H}-1 \mathrm{a}\right), 2.98\left(\mathrm{dd}, J_{1 \mathrm{~b}, 2}=9.7, J_{1 \mathrm{a}, 1 \mathrm{~b}}=13.2 \mathrm{~Hz}, 1 \mathrm{H}, \mathrm{H}-1 \mathrm{~b}\right)$; ${ }^{13} \mathrm{C}$ NMR (75 MHz, $\left.\mathrm{D}_{2} \mathrm{O}\right) \delta 135.8$ (C4), 117.9 (C5), 73.9 (C3), 72.0 (C2), 42.0 (C1); $\mathrm{HRMS}(E S I) ~ m / z$ calcd. for $\left[\mathrm{C}_{5} \mathrm{H}_{11} \mathrm{O}_{2} \mathrm{~N}+\mathrm{H}\right]^{+}: 118.0863$, obsd.: 118.0871 .<smiles>C=C[C@H](O)C(O)CN</smiles>

(2S,3R)-1-Amino-pent-4-ene-2,3-diol hydrochloride (5). By subjecting riboside $4(51.2 \mathrm{mg}, 0.19 \mathrm{mmol})$ to the general procedure for the synthesis of alkenylamines, alkenylamine 5 was obtained as the $\mathrm{HCl}$ salt (26 mg, $0.17 \mathrm{mmol}, 91 \%) . \mathrm{R}_{f}=0.41\left(\mathrm{DCM} / \mathrm{EtOH} / \mathrm{MeOH} / 30 \%\right.$ aqueous $\mathrm{NH}_{3}, 5 / 2 / 2 / 1$, $\mathrm{v} / \mathrm{v} / \mathrm{v} / \mathrm{v}) ;[\alpha]_{\mathrm{D}}{ }^{18}=+8.2(c=0.28, \mathrm{EtOH}) ;$ IR (film) 3345, 2946, 2835, 1651, 1450 , $1018 \mathrm{~cm}^{-1} .{ }^{1} \mathrm{H}$ NMR $\left(300 \mathrm{MHz}, \mathrm{D}_{2} \mathrm{O}\right) \delta 5.88\left(\mathrm{ddd}, J_{3,4}=6.6, J_{4,5 \text {-cis }}=10.5, J_{4,5 \text {-trans }}\right.$ $=17.1 \mathrm{~Hz}, 1 \mathrm{H}, \mathrm{H}-4), 5.35\left(\mathrm{~d}, J_{4,5-\text { trans }}=17.1 \mathrm{~Hz}, 1 \mathrm{H}, \mathrm{H}-5\right.$-trans $), 5.31\left(\mathrm{~d}, J_{4,5-c i s}=\right.$ $10.5 \mathrm{~Hz}, 1 \mathrm{H}, \mathrm{H}-5-c i s), 4.12\left(\mathrm{dd}, J_{2,3}=5.6, J_{3,4}=6.6 \mathrm{~Hz}, 1 \mathrm{H}, \mathrm{H}-3\right), 3.81$ (ddd, $J_{1 \mathrm{a}, 2}$ $\left.=3.0, J_{2,3}=5.6, J_{1 \mathrm{~b}, 2}=9.7 \mathrm{~Hz}, 1 \mathrm{H}, \mathrm{H}-2\right), 3.23\left(\mathrm{dd}, J_{1 \mathrm{a}, 2}=3.0, J_{1 \mathrm{a}, 1 \mathrm{~b}}=13.2 \mathrm{~Hz}, 1 \mathrm{H}\right.$, $\mathrm{H}-1 \mathrm{a}), 2.95\left(\mathrm{dd}, J_{1 \mathrm{~b}, 2}=9.7, J_{1 \mathrm{a}, 1 \mathrm{~b}}=13.2 \mathrm{~Hz}, 1 \mathrm{H}, \mathrm{H}-1 \mathrm{~b}\right) ;{ }^{13} \mathrm{C} \mathrm{NMR}\left(75 \mathrm{MHz}, \mathrm{D}_{2} \mathrm{O}\right)$ ठ 135.4 (C4), 118.3 (C5), 74.0 (C3), 69.8 (C2), 41.1 (C1); HRMS(ESI) m/z calcd. for $\left[\mathrm{C}_{5} \mathrm{H}_{11} \mathrm{O}_{2} \mathrm{~N}+\mathrm{H}\right]^{+}:$118.0863, obsd.: 118.0873 .<smiles>C=C[C@H](O)C[NH2+][Hg]Cl</smiles>

(2R,3R)-1-Amino-pent-4-ene-2,3-diol hydrochloride (7). By subjecting arabinoside $6(274 \mathrm{mg}, 1 \mathrm{mmol})$ to the general procedure for the synthesis of alkenylamines, alkenylamine 7 was obtained as the $\mathrm{HCl}$ salt $(143 \mathrm{mg}$, $93 \mathrm{mmol}, 93 \%) . \mathrm{R}_{f}=0.61\left(\mathrm{DCM} / \mathrm{EtOH} / \mathrm{MeOH} / 30 \%\right.$ aqueous $\mathrm{NH}_{3}, 5 / 2 / 2 / 1$, $\mathrm{v} / \mathrm{v} / \mathrm{v} / \mathrm{v}) ;[\alpha]_{\mathrm{D}}{ }^{20}=+50.6(\mathrm{c}=1.0, \mathrm{EtOH}) ;$ IR $($ film) $3412,3252,3045,1632,1432$, $1013 \mathrm{~cm}^{-1} .{ }^{1} \mathrm{H} \mathrm{NMR}\left(500 \mathrm{MHz}, \mathrm{D}_{2} \mathrm{O}\right) \delta 5.74\left(\mathrm{ddd}, J_{3,4}=5.3, J_{4,5 \text {-cis }}=10.5, J_{4,5 \text {-trans }}\right.$ $=17.3 \mathrm{~Hz}, 1 \mathrm{H}, \mathrm{H}-4), 5.23\left(\mathrm{~d}, J_{4,5-\text { trans }}=17.3 \mathrm{~Hz}, 1 \mathrm{H}, \mathrm{H}-5\right.$-trans $), 5.17$ (d, J,5-cis $=$ $10.5 \mathrm{~Hz}, 1 \mathrm{H}, \mathrm{H}-5-c i s), 3.99$ (t, $\left.J_{3,4}=J_{2,3}=5.3 \mathrm{~Hz}, 1 \mathrm{H}, \mathrm{H}-3\right), 3.70$ (ddd, $J_{1 \mathrm{a}, 2}=2.8$, $\left.J_{2,3}=5.3, J_{1 \mathrm{~b}, 2}=9.9 \mathrm{~Hz}, 1 \mathrm{H}, \mathrm{H}-2\right), 3.03\left(\mathrm{dd}, J_{1 \mathrm{a}, 2}=9.9, J_{1 \mathrm{a}, 1 \mathrm{~b}}=13.1 \mathrm{~Hz}, 1 \mathrm{H}, \mathrm{H}-\right.$ 1a), $2.87\left(\mathrm{dd}, J_{1 \mathrm{a}, 2}=2.8, J_{1 \mathrm{a}, 1 \mathrm{~b}}=13.1 \mathrm{~Hz}, 1 \mathrm{H}, \mathrm{H}-1 \mathrm{~b}\right) ;{ }^{13} \mathrm{C} \mathrm{NMR}\left(125 \mathrm{MHz}, \mathrm{D}_{2} \mathrm{O}\right) \delta$ 135.4 (C4), 118.2 (C5), 73.7 (C3), 69.7 (C2), 41.5 (C1). HRMS(ESI) m/z calcd. for $\left[\mathrm{C}_{5} \mathrm{H}_{11} \mathrm{O}_{2} \mathrm{~N}+\mathrm{H}\right]^{+}: 118.0863$, obsd: 118.0869 . 
$\overbrace{\overline{\bar{O}} \mathrm{H}}^{\mathrm{NH}_{2}} \cdot \mathrm{HCl}$

(R)-5-Amino-pent-1-en-3-ol hydrochloride (9). Вy subjecting deoxyriboside $8(100 \mathrm{mg}, 0.38 \mathrm{mmol})$ to the general procedure for the synthesis of alkenylamines, alkenylamine 9 was obtained as the $\mathrm{HCl}$ salt (42 mg, $0.31 \mathrm{mmol}, 81 \%) . \mathrm{R}_{f}=0.4\left(\mathrm{DCM} / \mathrm{EtOH} / \mathrm{MeOH} / 30 \%\right.$ aqueous $\mathrm{NH}_{3}, 5 / 2 / 2 / 1$, $\mathrm{v} / \mathrm{v} / \mathrm{v} / \mathrm{v}) ;[\alpha]_{\mathrm{D}}{ }^{17}=-3.2(\mathrm{c}=0.1, \mathrm{EtOH}) ;$ IR (film), 3359, 3047, 2955, 2927, 2854, 1635, 1428, 1134, $1056 \mathrm{~cm}^{-1} ;{ }^{1} \mathrm{H}$ NMR $\left(500 \mathrm{MHz}, \mathrm{D}_{2} \mathrm{O}\right) \delta 5.35\left(\mathrm{ddd}, J_{3,4}=6.1\right.$, $\left.J_{4,5 \mathrm{~b}}=10.5, J_{4,5 \mathrm{a}}=17.3 \mathrm{~Hz}, 1 \mathrm{H}, \mathrm{H} 4\right), 5.06\left(\mathrm{dd}, J_{5 \mathrm{a}, 5 \mathrm{~b}}=1.3, J_{4,5 \mathrm{a}}=17.3 \mathrm{~Hz}, 1 \mathrm{H}, \mathrm{H}-\right.$ $5 \mathrm{a}), 5.04\left(\mathrm{dd}, J_{5 \mathrm{a}, 5 \mathrm{~b}}=1.3, J_{4,5 \mathrm{~b}}=10.5 \mathrm{~Hz}, 1 \mathrm{H}, \mathrm{H}-5 \mathrm{~b}\right), 4.04\left(\mathrm{ddd}, J_{3,4}=6.1, J_{2 \mathrm{a}, 3}=\right.$ $\left.5.2, J_{2 \mathrm{~b}, 3}=7.3 \mathrm{~Hz}, 1 \mathrm{H}, \mathrm{H}-3\right), 2.96(\mathrm{~m}, 2 \mathrm{H}, \mathrm{H}-1), 1.38(\mathrm{~m}, 2 \mathrm{H}, \mathrm{H}-2) ;{ }^{13} \mathrm{C}$ NMR (125 MHz, D $2 \mathrm{O}) \delta 138.8$ (C4), 115.8 (C5), 70.1 (C3), 36.3 (C1), 32.9 (C2). HRMS(ESI) $m / z$ calcd. for $\left[\mathrm{C}_{5} \mathrm{H}_{11} \mathrm{NO}+\mathrm{H}\right]^{+}: 102.0919$, obsd.: 102.0921 .<smiles>C=C[C@@H](OCc1ccccc1)[C@H](Cl)CNCc1ccccc1</smiles>

(2S,3S)-2,3-Bis-benzyloxy-pent-4-enylamine

hydrochloride (11). To a solution of methyl arabinoside $\mathbf{1 0}(50.0 \mathrm{mg}, 0.110$ mmol) in a saturated solution of $\mathrm{NH}_{4} \mathrm{OAc}$ in $\mathrm{EtOH}(2.2 \mathrm{~mL})$ was added activated $\mathrm{Zn}(36 \mathrm{mg}, 0.550 \mathrm{mmol}), \mathrm{NaCNBH}_{3}(21 \mathrm{mg}, 0.330 \mathrm{mmol})$ and $30 \%$ aqueous $\mathrm{NH}_{3}$ $(0.88 \mathrm{~mL})$. The mixture was stirred at reflux for $18 \mathrm{~h}$, cooled to room temperature and concentrated under reduced pressure. The residue was redissolved in $10 \mathrm{~mL}$ EtOAc and made basic using $1 \mathrm{M} \mathrm{NaOH}$. The layers were separated, and the aqueous layer extracted with EtOAc. Organic extracts were combined and washed with brine, dried $\left(\mathrm{MgSO}_{4}\right)$, and concentrated under reduced pressure to obtain alkenylamine 11 together with dimer, in a 3:1 ratio (monomer:dimer), as a colourless oil (29 mg, $0.096 \mathrm{mmol}, 81 \%$ ). Amine 11 was purified using gradient flash chromatography (DCM/EtOH/MeOH/30\% aqueous $\mathrm{NH}_{3}, 475 / 2 / 2 / 1$ to $95 / 2 / 2 / 1, \mathrm{v} / \mathrm{v} / \mathrm{v} / \mathrm{v})$, then converted to the $\mathrm{HCl}$ salt. Monomer: $\mathrm{R}_{f}=0.31$ $\left(\mathrm{DCM} / \mathrm{EtOH} / \mathrm{MeOH} / 30 \%\right.$ aqueous $\left.\mathrm{NH}_{3}, 95 / 2 / 2 / 1, \mathrm{v} / \mathrm{v} / \mathrm{v} / \mathrm{v}\right) ;[\alpha]_{\mathrm{D}}{ }^{20}=+6.0(c=$ 0.3, $\mathrm{CHCl}_{3}$ ); IR (film) 3371, 3087, 3064, 3030, 2924, 2866, 2054, 1955, 1641, 1586, 1496, 1454, 1390, 1352, 1307, 1207, 1088, 996, 927, 734, $697 \mathrm{~cm}^{-1} .{ }^{1} \mathrm{H}$ $\operatorname{NMR}\left(500 \mathrm{MHz}, \mathrm{CDCl}_{3}\right) \delta 7.38-7.27(\mathrm{~m}, 10 \mathrm{H}, \mathrm{CH} \mathrm{Ph}), 5.84\left(\mathrm{ddd}, J_{3,4}=7.5\right.$, 
$\left.J_{4,5-c i s}=10.6, J_{4,5-t r a n s}=17.1 \mathrm{~Hz}, 1 \mathrm{H}, \mathrm{H}-4\right), 5.34\left(\mathrm{~d}, J_{4,5-c i s}=10.6 \mathrm{~Hz}, 1 \mathrm{H}, \mathrm{H}-5 \mathrm{cis}\right)$, $5.33\left(\mathrm{~d}, J_{4,5-\text { trans }}=17.1 \mathrm{~Hz}, 1 \mathrm{H}, \mathrm{H}-5\right.$ trans $), 4.81\left(\mathrm{~d}, J_{\mathrm{Ha}, \mathrm{Hb}}=11.5 \mathrm{~Hz}, 1 \mathrm{H}, \underline{\mathrm{C}}_{\underline{a}} \mathrm{H}_{\mathrm{b}}\right.$ $\mathrm{Bn}), 4.65\left(\mathrm{~d}, J_{\mathrm{Ha}, \mathrm{Hb}}=11.9 \mathrm{~Hz}, 1 \mathrm{H}, \mathrm{C}_{\underline{a}} \mathrm{H}_{\mathrm{b}} \mathrm{Bn}\right), 4.62\left(\mathrm{~d}, J_{\mathrm{Ha}, \mathrm{Hb}}=11.5 \mathrm{~Hz}, 1 \mathrm{H}\right.$, $\left.\mathrm{CH}_{\mathrm{a}} \underline{\mathrm{H}}_{\underline{\mathrm{b}}} \mathrm{Bn}\right), 4.41\left(\mathrm{~d}, J_{\mathrm{Ha}, \mathrm{Hb}}=11.5 \mathrm{~Hz}, 1 \mathrm{H}, \mathrm{CH}_{\mathrm{a}} \underline{\mathrm{H}}_{\underline{\mathrm{b}}} \mathrm{Bn}\right), 3.96\left(\mathrm{dd}, J_{2,3}=5.7, J_{3,4}=\right.$ $7.5 \mathrm{~Hz}, 1 \mathrm{H}, \mathrm{H}-3$ ), 3.50 (ddd, $\left.J_{1 \mathrm{a}, 2}=3.8, J_{2,3}=5.7, J_{1 \mathrm{~b}, 2}=7.7 \mathrm{~Hz}, 1 \mathrm{H}, \mathrm{H}-2\right), 2.87$ $\left(\mathrm{dd}, J_{1 \mathrm{a}, 2}=3.8, J_{1 \mathrm{a}, 1 \mathrm{~b}}=13.2 \mathrm{~Hz}, 1 \mathrm{H}, \mathrm{H}-1 \mathrm{a}\right), 2.73\left(\mathrm{dd}, J_{1 \mathrm{~b}, 2}=7.7, J_{1 \mathrm{a}, 1 \mathrm{~b}}=13.2 \mathrm{~Hz}\right.$, $1 \mathrm{H}, \mathrm{H}-1 \mathrm{~b}) ;{ }^{13} \mathrm{C} \mathrm{NMR}\left(125 \mathrm{MHz}, \mathrm{CDCl}_{3}\right) \delta$ 138.6, $138.4\left(\mathrm{C}_{\mathrm{q}} \mathrm{Ph}\right), 135.0(\mathrm{C} 4)$, 128.4 - $127.6(\mathrm{CH} \mathrm{Ph}), 119.0$ (C5), 82.8 (C2), 81.5 (C3), $73.6\left(\underline{\mathrm{CH}}_{2} \mathrm{Bn}\right.$ on $\left.\mathrm{C} 2\right)$, $70.6\left(\underline{\mathrm{CH}_{2}} \mathrm{Bn}\right.$ on $\left.\mathrm{C} 3\right), 42.5(\mathrm{C} 1)$; HRMS(ESI) $\mathrm{m} / z$ calcd. for $\left[\mathrm{C}_{19} \mathrm{H}_{23} \mathrm{NO}_{2}+\mathrm{H}\right]^{+}$: 298.1807, obsd.: 298.1808.<smiles>C=CC(OCc1ccccc1)C(Cl)CN</smiles>

\section{(2S,3R)-2,3-Bis-benzyloxy-pent-4-enylamine}

hydrochloride (13). To a solution of methyl riboside 12 (305 $\mathrm{mg}, 0.671 \mathrm{mmol})$ in a saturated solution of $\mathrm{NH}_{4} \mathrm{OAc}$ in EtOH $(13 \mathrm{~mL})$ was added activated $\mathrm{Zn}$ (219 mg, $3.36 \mathrm{mmol}), \mathrm{NaCNBH}_{3}(125 \mathrm{mg}, 2.011 \mathrm{mmol})$ and 30\% aqueous $\mathrm{NH}_{3}(5.3$ $\mathrm{mL}$ ). The mixture was stirred at reflux for $18 \mathrm{~h}$, cooled to room temperature and concentrated under reduced pressure. The residue was redissolved in $20 \mathrm{~mL}$ EtOAc and made basic using $1 \mathrm{M} \mathrm{NaOH}$. The layers were separated, and the aqueous layer extracted with ethyl acetate (twice with $20 \mathrm{~mL}$ ). Organic extracts were combined and washed with brine, dried $\left(\mathrm{MgSO}_{4}\right)$, and concentrated under reduced pressure to obtain alkenylamine $\mathbf{1 3}$ together with dimer, in a 3:1 ratio (monomer:dimer), as a colourless oil (218 mg, $0.655 \mathrm{mmol}, 98 \%$ ). Amine 13 was purified using gradient flash chromatography $(\mathrm{DCM} / \mathrm{EtOH} / \mathrm{MeOH} / 30 \%$ aqueous $\mathrm{NH}_{3}, 475 / 2 / 2 / 1$ to $\left.95 / 2 / 2 / 1, \mathrm{v} / \mathrm{v} / \mathrm{v} / \mathrm{v}\right)$, then converted to the $\mathrm{HCl}$ salt. Monomer: $\mathrm{R}_{f}$ $=0.23\left(\mathrm{DCM} / \mathrm{EtOH} / \mathrm{MeOH} / 30 \%\right.$ aqueous $\left.\mathrm{NH}_{3}, 95 / 2 / 2 / 1, \mathrm{v} / \mathrm{v} / \mathrm{v} / \mathrm{v}\right) ;[\alpha]_{\mathrm{D}}{ }^{21}=-40.4$ $\left(c=1, \mathrm{CHCl}_{3}\right.$ ); IR (film) 3379, 3064, 3030, 2865, 1952, 1675, 1586, 1454, 1349, 1206, 1089, 1066, 994, 927, 734, $696 \mathrm{~cm}^{-1} .{ }^{1} \mathrm{H}$ NMR (500 MHz, $\left.\mathrm{CDCl}_{3}\right) \delta 7.36$ $7.27(\mathrm{~m}, 10 \mathrm{H}, \mathrm{CH} \mathrm{Ph}), 5.89\left(\mathrm{ddd}, J_{3,4}=7.7, J_{4,5-c i s}=10.5, J_{4,5-\text { trans }}=17.2 \mathrm{~Hz}, 1 \mathrm{H}\right.$, H-4), 5.37 (d, $J_{4,5-c i s}=10.5 \mathrm{~Hz}, 1 \mathrm{H}, \mathrm{H}-5$-cis), 5.34 (d, $J_{4,5-\text { trans }}=17.2 \mathrm{~Hz}, 1 \mathrm{H}, \mathrm{H}-5$ trans), $4.70\left(\mathrm{~d}, J_{\mathrm{Ha}, \mathrm{Hb}}=11.4 \mathrm{~Hz}, 1 \mathrm{H}, \underline{\mathrm{C}}_{\underline{a}} \mathrm{H}_{\mathrm{b}} \mathrm{Bn}\right), 4.65\left(\mathrm{~d}, J_{\mathrm{Ha}, \mathrm{Hb}}=11.9 \mathrm{~Hz}, 1 \mathrm{H}\right.$, $\left.\mathrm{C}_{\underline{a}} \mathrm{H}_{\mathrm{b}} \mathrm{Bn}\right), 4.56\left(\mathrm{~d}, J_{\mathrm{Ha}, \mathrm{Hb}}=11.4 \mathrm{~Hz}, 1 \mathrm{H}, \mathrm{CH}_{\mathrm{a}} \underline{\mathrm{H}}_{\mathrm{b}} \mathrm{Bn}\right), 4.38\left(\mathrm{~d}, J_{\mathrm{Ha}, \mathrm{Hb}}=11.9 \mathrm{~Hz}\right.$, $\left.1 \mathrm{H}, \mathrm{CH}_{\mathrm{a}} \underline{\mathrm{H}}_{\mathrm{b}} \mathrm{Bn}\right), 3.89\left(\mathrm{dd}, J_{2,3}=5.3, J_{3,4}=7.7 \mathrm{~Hz}, 1 \mathrm{H}, \mathrm{H}-3\right), 3.47\left(\mathrm{ddd}, J_{1 \mathrm{~b}, 2}=4.1\right.$, 
$\left.J_{2,3}=5.3, J_{1 \mathrm{a}, 1 \mathrm{~b}}=5.6 \mathrm{~Hz}, 1 \mathrm{H}, \mathrm{H}-2\right), 5.89-5.82(\mathrm{~m}, 2 \mathrm{H}, \mathrm{H}-1 \mathrm{a}$ and $\mathrm{H}-1 \mathrm{~b}) ;{ }^{13} \mathrm{C} \mathrm{NMR}$ $\left(125 \mathrm{MHz}, \mathrm{CDCl}_{3}\right) \delta$ 138.5, $138.3\left(\mathrm{C}_{\mathrm{q}} \mathrm{Ph}\right), 135.8(\mathrm{C} 4), 128.4$ - $127.6(\mathrm{CH} \mathrm{Ph})$, 119.2 (C5), 82.8 (C2), 80.5 (C3), $72.8\left(\underline{\mathrm{CH}}_{2} \mathrm{Bn}\right.$ on $\left.\mathrm{C} 2\right), 70.3\left(\underline{\mathrm{CH}}_{2} \mathrm{Bn}\right.$ on $\left.\mathrm{C} 3\right)$, 42.3 (C1); HRMS(ESI) $\mathrm{m} / z$ calcd. for $\left[\mathrm{C}_{19} \mathrm{H}_{23} \mathrm{NO}_{2}+\mathrm{H}\right]^{+}$: 298.1807, obsd.: 298.1804. Dimer: $\mathrm{R}_{f}=0.72\left(\mathrm{DCM} / \mathrm{EtOH} / \mathrm{MeOH} / 30 \%\right.$ aqueous $\mathrm{NH}_{3}, 95 / 2 / 2 / 1$, v/v/v/v); HRMS(ESI) $m / z$ calcd. for $\left[\mathrm{C}_{38} \mathrm{H}_{43} \mathrm{NO}_{4}+\mathrm{H}\right]^{+}: 578.3265$, obsd.: 578.3263 .<smiles>C=CC(O)C(O)C(O)CNCCl</smiles>

\section{(2S,3S,4R)-1-Amino-hex-5-ene-2,3,4-triol}

hydrochloride (15). By subjecting glucoside $14(890 \mathrm{mg}, 2.93 \mathrm{mmol})$ to the general procedure for the synthesis of alkenylamines, alkenylamine 15 was obtained as the $\mathrm{HCl}$ salt $(501 \mathrm{mg}, 2.74 \mathrm{mmol}, 93 \%) . \quad \mathrm{R}_{f}=0.20$ $\left(\mathrm{DCM} / \mathrm{EtOH} / \mathrm{MeOH} / 30 \%\right.$ aqueous $\left.\mathrm{NH}_{3}, 5 / 2 / 2 / 1, \mathrm{v} / \mathrm{v} / \mathrm{v} / \mathrm{v}\right) ;[\alpha]_{\mathrm{D}}{ }^{17}=+6.6(c=1.0$, EtOH); IR (film) 3320, 3227, 3046, 2925, 1622, 1550, 1409, 1342, 1127, 1066, $1016,935,840,737 \mathrm{~cm}^{-1} .{ }^{1} \mathrm{H}$ NMR $\left(500 \mathrm{MHz}, \mathrm{D}_{2} \mathrm{O}\right) \delta 5.71\left(\mathrm{ddd}, J_{4,5}=6.9, J_{5,6 \text {-cis }}\right.$ $\left.=10.6, J_{5,6 \text {-trans }}=17.2 \mathrm{~Hz}, 1 \mathrm{H}, \mathrm{H}-5\right), 5.21$ (d, $J_{5,6-\text { trans }}=17.2 \mathrm{~Hz}, 1 \mathrm{H}, \mathrm{H}-6$-trans), $5.14\left(\mathrm{~d}, J_{5,6-c i s}=10.6 \mathrm{~Hz}, 1 \mathrm{H}, \mathrm{H}-6-c i s\right), 4.05\left(\mathrm{dd}, J_{3,4}=6.7, J_{4,5}=6.9 \mathrm{~Hz}, 1 \mathrm{H}, \mathrm{H}-\right.$ 4), $3.80\left(\mathrm{ddd}, J_{2,3}=2.9, J_{1 \mathrm{a}, 2}=4.8, J_{1 \mathrm{~b}, 2}=7.6 \mathrm{~Hz}, 1 \mathrm{H}, \mathrm{H}-2\right), 3.36\left(\mathrm{dd}, J_{2,3}=2.9\right.$, $\left.J_{3,4}=6.7 \mathrm{~Hz}, 1 \mathrm{H}, \mathrm{H}-3\right), 2.98(\mathrm{~m}, 2 \mathrm{H}, \mathrm{H}-1 \mathrm{a}$ and $\mathrm{H}-1 \mathrm{~b}) ;{ }^{13} \mathrm{C} \mathrm{NMR}\left(125 \mathrm{MHz}, \mathrm{D}_{2} \mathrm{O}\right)$ ઈ 135.8 (C5), 118.4 (C6), 74.2 (C3), 73.2 (C4), 67.0 (C2), 42.3 (C1); HRMS(ESI) $m / z$ calcd. for $\left[\mathrm{C}_{6} \mathrm{H}_{13} \mathrm{NO}_{3}+\mathrm{H}\right]^{+}: 148.0974$, obsd.: 148.0977 .

General procedure for the synthesis of glycamines. To a solution of hemiacetal (1 mmol) in a saturated solution of $\mathrm{NH}_{4} \mathrm{OAc}$ in $\mathrm{EtOH}(20 \mathrm{~mL})$ was added $\mathrm{NaCNBH}_{3}(188 \mathrm{mg}, 3 \mathrm{mmol})$ and $30 \%$ aqueous $\mathrm{NH}_{3}(8 \mathrm{~mL})$. The mixture was stirred at reflux for $18 \mathrm{~h}$, cooled to room temperature and concentrated under reduced pressure. The residue was redissolved in $\mathrm{H}_{2} \mathrm{O}$, loaded on to a Dowex $\mathrm{H}^{+}$ ion exchange resin, and washed several times with $\mathrm{H}_{2} \mathrm{O}$ to remove excess salt. The amine product was then eluted with 15 to $30 \%$ aqueous $\mathrm{NH}_{3}$ and the eluent was concentrated under reduced pressure. 
$\widehat{Y} \widehat{T}_{7} \mathrm{NH}_{2} \cdot \mathrm{HCl}$

Nonylamine hydrochloride (19). By subjecting aldehyde 18 (430 $\mathrm{mg}, 3.03 \mathrm{mmol}$ ) to the general procedure for the synthesis of glycamines, nonylamine 19 was obtained as the acetate salt, which was then converted into the $\mathrm{HCl}$ salt by the addition of $1 \mathrm{M} \mathrm{HCl}$ and compound 19 was obtained in $98 \%$ yield (534 mg, $2.97 \mathrm{mmol}$ ). All spectroscopic data was in full agreement with that of a commercial sample (Aldrich).<smiles>NC[C@@H](O)[C@H](O)[C@H](O)CO</smiles>

1-Amino-1-deoxy-D-arabinitol hydrochloride (21). By subjection of arabinose (20) (150 mg, $1 \mathrm{mmol}$ ) to the general procedure for the synthesis of glycamines, glycamine $\mathbf{2 1}$ was obtained as the acetate salt. Addition of $\mathrm{HCl}(1 \mathrm{M})$, followed by concentration gave the $\mathrm{HCl}$ salt of 21 (128 mg, 0.85 $\mathrm{mmol}, 85 \%) . \mathrm{R}_{f}=0.01\left(\mathrm{DCM} / \mathrm{EtOH} / \mathrm{MeOH} / \mathrm{NH}_{3}\right.$ (aq.), 5/2/2/1, v/v/v/v); $[\alpha]_{\mathrm{D}}{ }^{16}=$ +14.8 (c = 1.2, $\mathrm{H}_{2} \mathrm{O}$ ); IR (film), 3372, 3364, 2967, 2943, 1634, 1070, $1032 \mathrm{~cm}^{-1}$; ${ }^{1} \mathrm{H}$ NMR $\left(500 \mathrm{MHz}, \mathrm{D}_{2} \mathrm{O}\right) \delta 3.99\left(\mathrm{ddd}, J_{2,3}=1.8, J_{1 \mathrm{a}, 2}=5.4, J_{1 \mathrm{~b}, 2}=7.4 \mathrm{~Hz}, 1 \mathrm{H}, \mathrm{H}-\right.$ 2), 3.68, $\left(\mathrm{dd}, J_{4,5 \mathrm{a}}=2.9, J_{5 \mathrm{a} .5 \mathrm{~b}}=11.8 \mathrm{~Hz}, 1 \mathrm{H}, \mathrm{H}-5 \mathrm{a}\right), 3.57\left(\mathrm{ddd}, J_{4,5 \mathrm{a}}=2.9, J_{4,5 \mathrm{~b}}=\right.$ $\left.5.9, J_{3,4}=8.9 \mathrm{~Hz}, 1 \mathrm{H}, \mathrm{H}-4\right), 3.51\left(\mathrm{dd}, J_{4,5 \mathrm{~b}}=5.9, J_{5 \mathrm{a}, 5 \mathrm{~b}}=11.8 \mathrm{~Hz}, 1 \mathrm{H}, \mathrm{H}-5 \mathrm{~b}\right), 3.27$ $\left(\mathrm{dd}, J_{2,3}=1.8, J_{3,4}=8.9 \mathrm{~Hz}, 1 \mathrm{H}, \mathrm{H}-3\right), 3.01(\mathrm{~m}, 2 \mathrm{H}, \mathrm{H}-1) ;{ }^{13} \mathrm{C}$ NMR $(125 \mathrm{MHz}$, $\left.\mathrm{D}_{2} \mathrm{O}\right) \delta 71.0(\mathrm{C} 2), 70.3(\mathrm{C} 3), 66.2$ (C4), 62.6 (C5), 42.4 (C1). HRMS(ESI) $\mathrm{m} / \mathrm{z}$ calcd. for $\left[\mathrm{C}_{5} \mathrm{H}_{13} \mathrm{NO}_{4}+\mathrm{H}\right]^{+}:$152.0923, obsd.: 152.0918 .<smiles>NCC[C@H](O)C(O)CO</smiles>

1-Amino-1,2-dideoxy-D-ribitol hydrochloride (23).

By subjecting 2-deoxyribose (22) (134 $\mathrm{mg}, 1 \mathrm{mmol})$ to the general procedure for the synthesis of glycamines, glycamine $\mathbf{2 3}$ was obtained as the acetate salt. Addition of $\mathrm{HCl}(1 \mathrm{M})$, followed by concentration gave $\mathrm{HCl}$ salt 23 (117 mg, 0.87 $\mathrm{mmol}, 87 \%) . \mathrm{R}_{f}=0.02\left(\mathrm{DCM} / \mathrm{EtOH} / \mathrm{MeOH} / \mathrm{NH}_{3}(\mathrm{aq}), 5 / 2 / 2 / 1, \mathrm{v} / \mathrm{v} / \mathrm{v} / \mathrm{v}\right) ;[\alpha]_{\mathrm{D}}{ }^{16}=$ +16.3 (c = 1.0, $\mathrm{H}_{2} \mathrm{O}$ ); IR (film), 3375, 3342, 3297, 2948, 2917, 1471, $1014 \mathrm{~cm}^{-1}$; ${ }^{1} \mathrm{H}$ NMR (500 MHz, D $\left.2 \mathrm{O}\right) \delta 3.57$ (m, 2H, H-3, and H-5a), 3.48 (m, 2H, H-4, and H-5b), 3.04 (m, 2H, H-1), 1.83 (dddd, $J=2.9, J=6.2, J=8.8, J_{2 \mathrm{a}, 2 \mathrm{~b}}=14.5 \mathrm{~Hz}$, $1 \mathrm{H}, \mathrm{H}-2 \mathrm{a}$ ), 1.64 (dddd, $J=6.6, J=8.2, J=9.8, J_{2 \mathrm{a}, 2 \mathrm{~b}}=14.5 \mathrm{~Hz}, 1 \mathrm{H}, \mathrm{H}-2 \mathrm{~b}$ ); ${ }^{13} \mathrm{C}$ 
NMR (125 MHz, D $2 \mathrm{O}) \delta 74.2$ (C4), 69.5 (C3), 62.2 (C5), 37.1 (C1), 29.2 (C2). HRMS(ESI) $m / z$ calcd. for $\left[\mathrm{C}_{5} \mathrm{H}_{13} \mathrm{NO}_{3}+\mathrm{H}\right]^{+}:$136.0974, obsd.: 136.0972 .

HO $\mathrm{NH}_{2} \cdot \mathrm{HCl}$ 4-Amino-butan-1-ol hydrochloride (25). By subjecting furanol $24(470 \mathrm{mg}, 5.34 \mathrm{mmol})$ to the general procedure for the synthesis of glycamines, glycamine $\mathbf{2 5}$ was obtained as the acetate salt together with its dimer in a 11:1 ratio (monomer:dimer). Addition of $\mathrm{HCl}(1 \mathrm{M})$, followed by concentration gave a mixture of the corresponding $\mathrm{HCl}$ salts $(401 \mathrm{mg}, 3.21 \mathrm{mmol}$, $60 \%$ ). Monomer and dimer were separated using gradient flash chromatography (DCM/EtOH/MeOH/30\% aqueous $\mathrm{NH}_{3}, 95 / 2 / 2 / 1$ to $10 / 2 / 2 / 1, \mathrm{v} / \mathrm{v} / \mathrm{v} / \mathrm{v}$ ) and converted to the $\mathrm{HCl}$ salt for characterisation. Monomer 25: $\mathrm{R}_{f}=0.24$ (DCM/EtOH/MeOH/30\% aqueous $\mathrm{NH}_{3}, 5 / 2 / 2 / 1$, v/v/v/v); IR (film) 3374, 3280, 3042, 2982, 2844, 1634, 1443, 1405, 1054, 1033, 1015, 907, $698 \mathrm{~cm}^{-1} .{ }^{1} \mathrm{H}$ NMR $\left(500 \mathrm{MHz}, \mathrm{D}_{2} \mathrm{O}\right) \delta 3.58\left(\mathrm{t}, J_{1,2}=6.5 \mathrm{~Hz}, 2 \mathrm{H}, \mathrm{H}-1\right), 2.98\left(\mathrm{t}, J_{3,4}=7.4 \mathrm{~Hz}, 2 \mathrm{H}, \mathrm{H}-4\right)$, $1.67\left(\mathrm{tt}, J_{3,4}=7.4 J_{2,3}=7.6 \mathrm{~Hz}, 2 \mathrm{H}, \mathrm{H}-3\right), 1.57\left(\mathrm{tt}, J_{1,2}=6.5, J_{2,3}=7.6 \mathrm{~Hz}, 2 \mathrm{H}, \mathrm{H}-\right.$ 2); ${ }^{13} \mathrm{C}$ NMR (125 MHz, $\left.\mathrm{D}_{2} \mathrm{O}\right) \delta 60.9$ (C1), 39.3 (C4), 28.2 (C2), 23.4 (C3); HRMS(ESI) $m / z$ calcd. for $\left[\mathrm{C}_{4} \mathrm{H}_{11} \mathrm{ON}+\mathrm{H}\right]^{+}:$90.0913, obsd.: 90.0911.

Bis-(5-hydroxy-butyl)-amine hydrochloride (dimer): $\quad \mathrm{R}_{f}=0.45$ (DCM/EtOH/MeOH/30\% aqueous $\mathrm{NH}_{3}, 5 / 2 / 2 / 1$, v/v/v/v); HRMS(ESI) $m / z$ calcd. for $\left[\mathrm{C}_{8} \mathrm{H}_{19} \mathrm{O}_{2} \mathrm{~N}+\mathrm{H}\right]^{+}$: 162.1494, obsd.: 162.1492 .<smiles>NC[C@@H](O)[C@@H](O)[C@H](O)[C@H](O)CO</smiles>

1-Amino-1-deoxy-D-glucitol hydrochloride (27).

By subjecting $26(180 \mathrm{mg}, 1 \mathrm{mmol})$ to the general procedure for the synthesis of glycamines, glycamine 27 was obtained as the acetate salt. Addition of $\mathrm{HCl}(1 \mathrm{M})$, followed by concentration gave $\mathrm{HCl}$ salt of 27 (156 mg, $0.86 \mathrm{mmol}, 86 \%) . \mathrm{R}_{f}=$ $0.01\left(\mathrm{DCM} / \mathrm{EtOH} / \mathrm{MeOH} / \mathrm{NH}_{3}(\mathrm{aq}), 5 / 2 / 2 / 1, \mathrm{v} / \mathrm{v} / \mathrm{v} / \mathrm{v}\right) ;[\alpha]_{\mathrm{D}}{ }^{16}=-6.1(\mathrm{c}=1.5$, $\mathrm{H}_{2} \mathrm{O}$ ); IR (film), 3431, 3388, 2975, 2947, 1633, 1090, 1054, $1014 \mathrm{~cm}^{-1} ;{ }^{1} \mathrm{H}$ NMR $\left(500 \mathrm{MHz}, \mathrm{D}_{2} \mathrm{O}\right) \delta 3.87\left(\mathrm{ddd} J_{1 \mathrm{a}, 2}=3.2, J_{2,3}=5.2, J_{1 \mathrm{~b}, 2}=9.5 \mathrm{~Hz}, 1 \mathrm{H}, \mathrm{H}-2\right), 3.65$ (m, 2H, H-6a, H-3) 3.58 (m, 1H, H-5), 3.48 (m, 2H, H-6b, H-4), 3.06 (dd, $J_{1 \mathrm{a}, 2}=$ $\left.3.2, J_{1 \mathrm{a}, 1 \mathrm{~b}}=13.1 \mathrm{~Hz}, 1 \mathrm{H}, \mathrm{H}-1 \mathrm{a}\right), 2.91\left(\mathrm{dd}, J_{1 \mathrm{~b}, 2}=9.5, J_{1 \mathrm{a}, 1 \mathrm{~b}}=13.1 \mathrm{~Hz}, 1 \mathrm{H}, \mathrm{H}-1 \mathrm{~b}\right)$; 
${ }^{13} \mathrm{C}$ NMR (125 MHz, D $\left.2 \mathrm{O}\right) \delta 70.7$ (C5), 70.6 (C4), 70.5 (C3), 69.9 (C2), 62.5 (C6), 41.8 (C1). HRMS(ESI) $m / z$ calcd. for $\left[\mathrm{C}_{6} \mathrm{H}_{15} \mathrm{NO}_{5}+\mathrm{H}\right]^{+}: 182.1028$, obsd.: 182.1028 .<smiles>NCCCC[C@H](O)CO</smiles>

6-Amino-hexane-1,2-diol hydrochloride (29). By subjecting pyranose $28(100 \mathrm{mg}, 0.763 \mathrm{mmol})$ to the general procedure for the synthesis of glycamines, glycamine 29 was obtained together with dimer in a 8:1 ratio (monomer:dimer) as the acetate salts. Addition of $\mathrm{HCl}(1 \mathrm{M})$, followed by concentration gave the $\mathrm{HCl}$ salts of $\mathbf{2 9}$ together with the corresponding dimer (83.7 mg, $0.495 \mathrm{mmol}, 65 \%)$. Monomer 29: $\mathrm{R}_{f}=0.18$ (DCM/EtOH/MeOH/30\% (aq) $\mathrm{NH}_{3}, 5 / 2 / 2 / 1, \mathrm{v} / \mathrm{v} / \mathrm{v} / \mathrm{v}$ ); IR (film) 3353, 3204, 2928, 2856, 1710, 1662, 1393, $1267,1125,1073,1046,1013,883,740 \mathrm{~cm}^{-1} .{ }^{1} \mathrm{H}$ NMR $\left(500 \mathrm{MHz}, \mathrm{D}_{2} \mathrm{O}\right) \delta 3.68$ $\left(\mathrm{ddd}, J_{1 \mathrm{a}, 2}=3.9, J_{1 \mathrm{~b}, 2}=6.8, J_{2,3}=10.9 \mathrm{~Hz}, 1 \mathrm{H}, \mathrm{H}-2\right), 3.56\left(\mathrm{dd}, J_{1 \mathrm{a}, 2}=3.9, J_{1 \mathrm{a}, 1 \mathrm{~b}}=\right.$ $11.7 \mathrm{~Hz}, 1 \mathrm{H}, \mathrm{H}-1 \mathrm{a}), 3.45$ (dd, $\left.J_{1 \mathrm{~b}, 2}=6.8, J_{1 \mathrm{a}, 1 \mathrm{~b}}=11.7 \mathrm{~Hz}, 1 \mathrm{H}, \mathrm{H}-1 \mathrm{~b}\right), 2.98\left(\mathrm{t}, J_{5,6}=\right.$ $7.7 \mathrm{~Hz}, 2 \mathrm{H}, \mathrm{H}-6), 1.67$ (m, 2H, H-5), 1.50 (m, 2H, H-3), 1.41 (m, 2H, H4) ; ${ }^{13} \mathrm{C}$ NMR (125 MHz, D 20$)$ \& 71.3 (C2), 65.2 (C1), 39.3 (C6), 31.5 (C3), 26.6 (C5), 21.7 (C4); HRMS(ESI) $m / z$ calcd. for $\left[\mathrm{C}_{6} \mathrm{H}_{15} \mathrm{NO}_{2}+\mathrm{H}\right]^{+}:$134.1176, obsd.: 134.1175.

6-(5,6-Dihydroxy-hexylamino)-hexane-1,2-diol hydrochloride (dimer): $\mathrm{R}_{f}=$ 0.34 (DCM/EtOH/MeOH/30\% aqueous $\left.\mathrm{NH}_{3}, 5 / 2 / 2 / 1, \mathrm{v} / \mathrm{v} / \mathrm{v} / \mathrm{v}\right) ;{ }^{1} \mathrm{H}$ NMR (500 $\left.\mathrm{MHz}, \mathrm{D}_{2} \mathrm{O}\right) \delta 3.68\left(\mathrm{ddd}, J_{1 \mathrm{a}, 2}=3.9, J_{1 \mathrm{~b}, 2}=6.8, J_{2,3}=10.9 \mathrm{~Hz}, 2 \mathrm{H}, \mathrm{H}-2\right), 3.56(\mathrm{dd}$, $\left.J_{1 \mathrm{a}, 2}=3.9, J_{1 \mathrm{a}, 1 \mathrm{~b}}=11.7 \mathrm{~Hz}, 2 \mathrm{H}, \mathrm{H}-1 \mathrm{a}\right), 3.45\left(\mathrm{dd}, J_{1 \mathrm{~b}, 2}=6.8, J_{1 \mathrm{a}, 1 \mathrm{~b}}=11.7 \mathrm{~Hz}, 2 \mathrm{H}, \mathrm{H}-\right.$ 1b), 3.02 (t, $\left.J_{5,6}=7.9 \mathrm{~Hz}, 4 \mathrm{H}, \mathrm{H}-6\right), 1.67$ (m, 4H, H-5), 1.50 (m, 4H, H-3), 1.41 (m, 4H, H4); ${ }^{13} \mathrm{C}$ NMR (125 MHz, D $\left.2 \mathrm{O}\right) \delta 71.3$ (C2), 65.2 (C1), 47.3 (C6), 31.5 (C3), 25.4 (C5), 21.8 (C4); HRMS(ESI) $m / z$ calcd. for $\left[\mathrm{C}_{12} \mathrm{H}_{27} \mathrm{NO}_{4}+\mathrm{H}\right]^{+}$: 250.2018, obsd.: 250.2020.

$\mathrm{NH}_{2} \cdot \mathrm{HCl}$ 5-Amino-pentan-1-ol hydrochloride (31). By subjecting pyranose $30(400 \mathrm{mg}, 3.92 \mathrm{mmol})$ to the general procedure for the synthesis of glycamines, glycamine $\mathbf{3 1}$ was obtained as the acetate salt together with dimer in a 7:1 ratio (monomer:dimer) then converted to the $\mathrm{HCl}$ salt (515 $\mathrm{mg}, 3.18 \mathrm{mmol}, 81 \%$ ). Monomer and dimer were then separated using gradient 
flash chromatography (DCM/EtOH/MeOH/30\% aqueous $\mathrm{NH}_{3}, 95 / 2 / 2 / 1$ to $10 / 2 / 2 / 1, \mathrm{v} / \mathrm{v} / \mathrm{v} / \mathrm{v}$ ) and converted to the $\mathrm{HCl}$ salts for characterisation. Monomer 31: $\mathrm{R}_{f}=0.44\left(\mathrm{DCM} / \mathrm{EtOH} / \mathrm{MeOH} / 30 \%\right.$ aqueous $\mathrm{NH}_{3}, 5 / 2 / 2 / 1, \mathrm{v} / \mathrm{v} / \mathrm{v} / \mathrm{v}$ ); IR (film) $3425,3294,2935,2868,1623,1517,1472,1208,1130,1022,951,736,699 \mathrm{~cm}^{-}$ ${ }^{1} .{ }^{1} \mathrm{H}$ NMR $\left(500 \mathrm{MHz}, \mathrm{D}_{2} \mathrm{O}\right) \delta 3.58\left(\mathrm{t}, J_{1,2}=6.7 \mathrm{~Hz}, 2 \mathrm{H}, \mathrm{H}-1\right), 2.95$ (t, $J_{5,4}=7.6$ $\mathrm{Hz}, 2 \mathrm{H}, \mathrm{H}-5), 1.64$ (tt, $\left.J_{3,4}=7.6, J_{4,5}=7.6 \mathrm{~Hz}, 2 \mathrm{H}, \mathrm{H}-4\right), 1.55$ (tt, $J_{1,2}=6.7, J_{2,3}=$ $7.5 \mathrm{~Hz}, 2 \mathrm{H}, \mathrm{H}-2), 1.39$ (tt, $\left.J_{2,3}=7.5, J_{3,4}=7.6 \mathrm{~Hz}, 2 \mathrm{H}, \mathrm{H}-3\right) ;{ }^{13} \mathrm{C} \mathrm{NMR}(125 \mathrm{MHz}$, $\left.\mathrm{D}_{2} \mathrm{O}\right) \delta 61.2$ (C1), 39.4 (C5), 30.6 (C2), 26.7 (C4), 21.9 (C3); HRMS(ESI) $m / z$ calcd. for $\left[\mathrm{C}_{5} \mathrm{H}_{13} \mathrm{ON}+\mathrm{H}\right]^{+}: 104.1075$, obsd.: 104.1070 .

5-(5-Hydroxy-pentylamino)-pentan-1-ol hydrochloride (dimer): $\mathrm{R}_{f}=0.63$ (DCM/EtOH/MeOH/30\% aqueous $\mathrm{NH}_{3}, 5 / 2 / 2 / 1$, v/v/v/v); IR (film) 3309, 3117, 2934, 2862, 1496, 1369, 1207, 1079, 1022, 734, $697 \mathrm{~cm}^{-1} .{ }^{1} \mathrm{H}$ NMR (500 MHz, $\left.\mathrm{D}_{2} \mathrm{O}\right) \delta 3.58\left(\mathrm{t}, J_{1,2}=6.5 \mathrm{~Hz}, 4 \mathrm{H}, \mathrm{H}-1\right), 2.82\left(\mathrm{t}, J_{4,5}=7.3 \mathrm{~Hz}, 4 \mathrm{H}, \mathrm{H}-5\right), 1.59$ (tt, $J_{3,4}=7.3, J_{4,5}=7.3 \mathrm{~Hz}, 4 \mathrm{H}, \mathrm{H}-4$ ), $1.55\left(\mathrm{tt}, J_{1,2}=6.5, J_{2,3}=7.6 \mathrm{~Hz}, 4 \mathrm{H}, \mathrm{H}-2\right), 1.36$ (tt, $\left.J_{2,3}=7.6, J_{3,4}=7.3 \mathrm{~Hz}, 4 \mathrm{H}, \mathrm{H}-3\right) ;{ }^{13} \mathrm{C} \mathrm{NMR}\left(125 \mathrm{MHz}, \mathrm{D}_{2} \mathrm{O}\right) \delta 61.3(\mathrm{C} 1)$, 47.7 (C5), 30.7 (C2), 26.4 (C4), 22.5 (C3); HRMS(ESI) $m / z$ calcd. for $\left[\mathrm{C}_{10} \mathrm{H}_{23} \mathrm{O}_{2} \mathrm{~N}+\mathrm{H}\right]^{+}:$190.1807, obsd.: 190.1801 . 


\subsection{References}

(1) Dangerfield, E. M.; Plunkett, C. H.; Win-Mason, A. L.; Stocker, B. L.; Timmer, M. S. M. J. Org. Chem. 2010, 75, 5470-5477.

(2) Lawrence, S. A. Amines: Synthesis, Properties and Applications; Cambridge University Press, 2004.

(3) Salvatore, R. N.; Yoon, C. H.; Jung, K. W. Tetrahedron 2001, 57, 77857811.

(4) Baxter, E.; Reitz, A. Organic Reactions 2002, 59, 1-714.

(5) Gomez, S.; Peters, J. A.; Maschmeyer, T. Adv. Synth. Catal. 2002, 344, 1037-1057.

(6) Bódis, J.; Lefferts, L.; Müller, T. E.; Pestman, R.; Lercher, J. A. Catal. Lett. 2005, 104, 23-28.

(7) Gomez, S.; Peters, J. A.; van der Waal, J. C.; van der Brink, P. J.; Maschmeyer, T. Appl. Catal., A 2004, 261, 119-125.

(8) Dangerfield, E. M.; Timmer, M. S. M.; Stocker, B. L. Org. Lett. 2009, 11, 535-538.

(9) Bernet, B.; Vasella, A. Helv. Chim. Acta. 1979, 62, 1990-2016.

(10) Skaanderup, P. R.; Poulsen, C. S.; Hyldtoft, L.; Jørgensen, M. R.; Madsen, R. Synthesis 2002, 12, 1721-1727.

(11) Fürstner, A.; Jumbam, D.; Teslic, J.; Weidmann, H. J. Org. Chem. 1991, 56, 2213-2217.

(12) Gurjar, M. K.; Nagaprasad, R.; Ramana, C. V. Tetrahedron Lett. 2002, 43, 7577-7579.

(13) Garlaschelli, L.; Mellerio, G.; Vidari, G. Tetrahedron 1989, 45, 73797386.

(14) Dubois, L.; Fiaud, J.-C.; Kagan, H. B. Tetrahedron 1995, 51, 3803-3812.

(15) Nieuwpoort, G.; Brussee, J.; Reedijk, J. Inorg. Chim. Acta. 1983, 68, 131135.

(16) Rustagi, S. C.; Rao, G. N. J. Inorg. Nucl. Chem. 1974, 36, 1161-1163.

(17) Kojima, M.; Nakamura, Y.; Nakamura, A.; Takeuchi, S. Tetrahedron Lett. 2009, 50, 939-942. 



\section{Chapter 6: Investigations into the Carbamate Annulation Reaction for the Synthesis of Five and Six Membered Azasugars ${ }^{1,2}$}

\subsection{Introduction}

The methodology developed (Chapter 4) for the synthesis of azasugars involved a protecting group free strategy whereby D-xylose was transformed into 1,4dideoxy-1,4-imino-D-xylitol (1) via the use of a Vasella reductive amination ${ }^{3}$ and a novel carbamate annulation reaction. ${ }^{4}$ To illustrate the versatility of this methodology and its application in the synthesis of azasugars, we wanted to explore the potential of our new methodology for the synthesis of three additional five membered azasugars 2, 3, and 4, ${ }^{1,2}$ and three six membered azasugars 5, 6, and 7 (Figure 6.1). This would enable us to develop an azasugar library, which could be screened at a later date to elucidate the biological activities that each azasugar possesses. 1,4-Dideoxy-1,4-imino-D-xylitol (1) is a known glycogen phosphorylase $\mathrm{b}$ inhibitor, ${ }^{5}$ however the biological activities of azasugars $\mathbf{2}, \mathbf{3}$ and 4 are currently unknown. DGJ (5) is an $\alpha$-galactosidase inhibitor, and a weak $\beta$ galactosidase inhibitor (see Chapter 1). ${ }^{6}$ Although 4-epi-fagomine (7) has not been found in nature, it was first obtained by transformation from fagomine, and was shown to be an $\alpha$-galactosidase inhibitor. ${ }^{7,8}$ 
<smiles>OCC1NCC(O)C1O</smiles><smiles>OC[C@H]1NC[C@@H](O)[C@H](O)[C@@H]1O</smiles>

5<smiles>OC[C@H]1NC[C@@H](O)[C@@H]1O</smiles><smiles>OC[C@H]1NCC(O)[C@H]1O</smiles><smiles>OC[C@@H]1NCC[C@H]1O</smiles><smiles>OC[C@H]1NC[C@@H](O)[C@H](O)[C@@H]1O</smiles>

6<smiles>OC[C@H]1NCC[C@@H](O)[C@@H]1O</smiles>

7

Figure 6.1. Target five and six membered azasugars.

\subsection{Results and Discussion}

\section{Synthesis of five membered azasugars}

To extend the scope of the protecting group free strategy to the synthesis of additional azasugars we set out to synthesise 1,4-dideoxy-1,4-imino-L-lyxitol 2 (Scheme 6.1). D-Ribose (8) was converted into to iodoglycoside 9 (67\%) using Fischer glycosidation followed by treatment with $\mathrm{I}_{2}$ and $\mathrm{PPh}_{3} .{ }^{9}$ Vasella reductive amination proceeded smoothly to give olefinic amine 10 (91\%). Halocyclisation/carbonylation using our iodine-promoted annulation methodology gave carbamate 11 in 93\% yield, and as a single diastereomer ( $>20: 1$ d.s.), as determined by ${ }^{1} \mathrm{H}$ NMR of the crude reaction mixture. (See chapter 6 for discussions concerning the diastereoselectivity of the reaction.) Carbamate $\mathbf{1 1}$ was subsequently hydrolysed to give 3,4-cis 1,4-dideoxy-1,4-imino-L-lyxitol (2) in a $97 \%$ yield, the data was in full agreement with those published. ${ }^{10}$ Overall 1,4dideoxy-1,4-imino-L-lyxitol was synthesised in five steps in 55\% yield, the highest reported to date. 


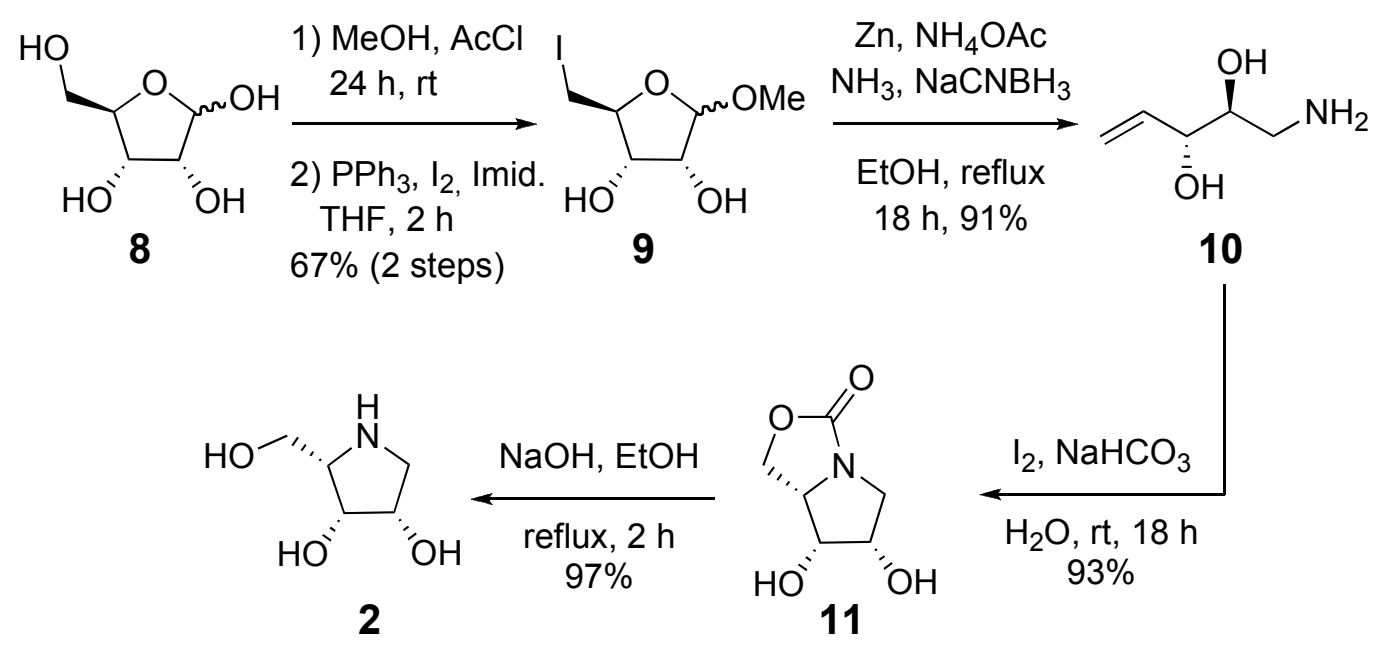

Scheme 6.1. Synthesis of 1,4-dideoxy-1,4-imino-L-lyxitol (2) from D-ribose.

The next target was 1,4-dideoxy-1,4-imino-L-xylitol (3), this synthesis commenced with the transformation of D-arabinose 12 into the corresponding methyl glycoside 13 and subsequent conversion to methyl iodoglycoside 14 (Scheme 6.2). ${ }^{9}$ Glycoside 14 was then subjected to the Vasella reductive amination protocol to give the corresponding linear alkenylamine $\mathbf{1 5}$ in excellent yield (91\%). Alkenylamine 15 was then cyclised using the iodine-mediated carbamate annulation methodology, providing carbamate 16, again in an excellent 93\% yield and as the only diastereomer. Hydrolysis of carbamate 16, and comparison of the NMR spectral data and optical rotation values of the hydrolysed product with those in the literature ${ }^{11,12}$ confirmed the identity of the resulting azasugar to be that of 1,4-dideoxy-1,4-imino-L-xylitol (3). With an overall yield of $54 \%$, this 5-step synthesis is remarkably efficient. Similar methodology was subsequently applied to the synthesis of 1,4-dideoxy-1,4-iminoD-lyxitol (not shown). ${ }^{2}$ 


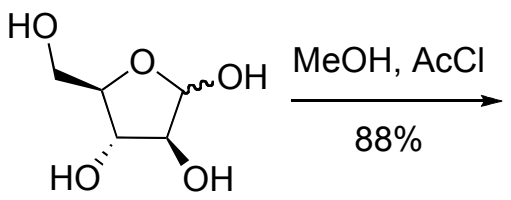

12<smiles>CO[C@H]1OC(CO)[C@@H](O)[C@H]1O</smiles>

13

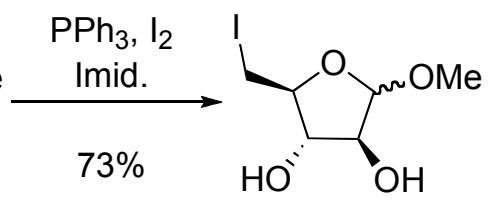

14

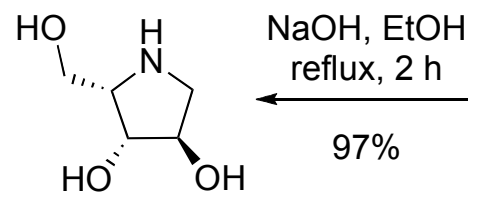

3<smiles>O=C1OC[C@@H]2[C@@H](O)C(O)CN12</smiles>

16<smiles>C=C[C@@H](O)[C@@H](O)CN</smiles>

15

Scheme 6.2. Protecting group free synthesis of 1,4-dideoxy-1,4-imino-L-xylitol (3).

To prepare 1,2,4-trideoxy-1,4-imino-L-xylitol (4) and explore the effect that the hydroxylation pattern had on the carbamate annulation, 2-deoxy-D-ribose (17) was subjected to Fischer glycosidation to generate the desired methyl glycoside 18 (Scheme 6.3). Given the propensity of 2-deoxy-D-ribose to form the thermodynamically more stable pyranose ring, short reaction times were required to favour formation of the desired furanoside. Thus, 2-deoxy-D-ribose was stirred with $1 \% \mathrm{AcCl}$ in $\mathrm{MeOH}$ for $15 \mathrm{~min}$., according to the procedure by Hoffer and co-workers. ${ }^{13}$ This resulted in almost exclusive formation of 2-deoxy-Dribofuranoside 17 with only trace amounts $(c a .5 \%)$ of the pyranose structural isomer. Longer reaction times resulted in the increase formation of the pyranose product. Installation of an iodide at the primary position was then attempted by refluxing a solution of methyl 2-deoxy-D-ribose 18, triphenylphosphine, $\mathrm{I}_{2}$ and imidazole in THF for $2 \mathrm{~h}$. Unfortunately, these conditions led to significant degradation. Milder reaction conditions, however, whereby the solution was stirred at room temperature for $18 \mathrm{~h},{ }^{14}$ allowed for the preparation of methyl 2,5dideoxy-5-iodo-D-riboside (19) in satisfactory yield (73\%). Vasella reductive amination of iodoriboside 19 gave linear alkenylamine 20 in good (81\%) yield. 

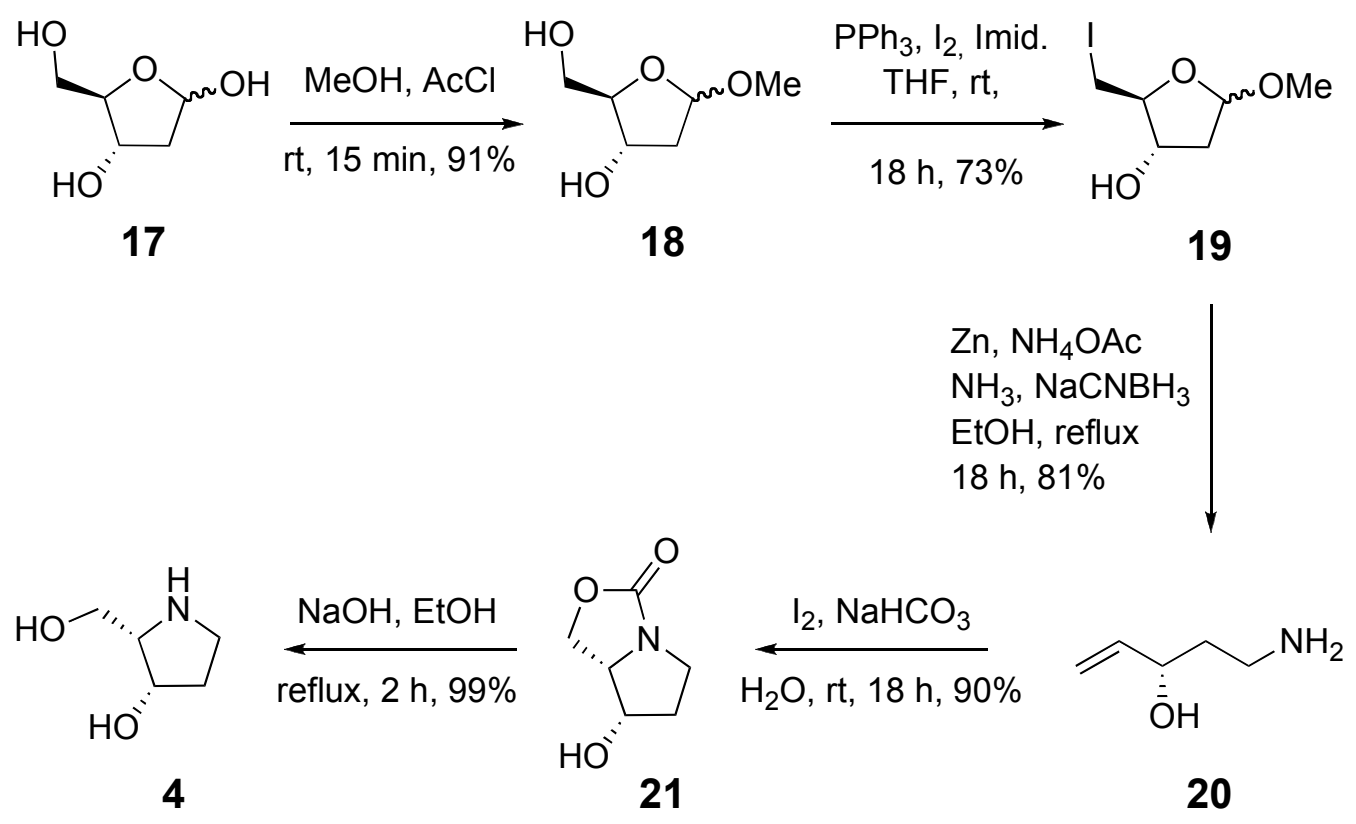

Scheme 6.3. Synthesis of 1,2,4-trideoxy-1,4-imino-L-xylitol.

Alkenylamine 20 was then subjected to the iodine-promoted carbamate annulation (Scheme 6.3). This reaction proceeded smoothly and gave the desired carbamate 21 in $90 \%$ yield and with a diastereoselectively of greater than 20:1 in favour of the 3,4-cis isomer, as determined by ${ }^{1} \mathrm{H}$ NMR of the crude reaction mixture. This demonstrated that the absence of the C-2 hydroxyl did not alter the stereochemical outcome of the cyclisation. Hydrolysis of carbamate 21, using $\mathrm{NaOH}$, proceeded uneventfully and gave the desired azasugar $\mathbf{4}$ in a quantative yield, as confirmed via comparison of spectral data with that previously reported. ${ }^{15-18}$ In sum, 1,2,4trideoxy-1,4-iminol-L-xylitol was prepared in 5 steps and in an overall yield of $48 \%$, the best reported to date. ${ }^{16}$

\section{Synthesis of six membered 1-deoxyazasugars}

With the objective of extending our carbamate methodology to the synthesis of six membered azasugars, we embarked on a synthesis of deoxygalactonojirimycin (DGJ, 5, Scheme 6.4), which is currently under investigation for the treatment of Fabry's disease. Our strategy began with the selective iodination of the 6 position of methyl galactoside 22 (commercially available) using iodine and triphenylphosphine. Under these conditions, however, only a modest (49\%) yield of methyl iodoglycoside $\mathbf{2 3}$ was obtained and the other major product observed 
was bicyclic compound 24. This by-product is most likely formed via nucleophilic attack of the 3-hydroxyl on the carbon at the 6-position, once the positively charged triphenylphosphine adduct has formed. To improve this yield and develop a more scalable synthesis of iodoglycoside $\mathbf{2 3}$, an alternative route was then developed. To this end, D-galactose (25) was treated with acetone and $\mathrm{ZnCl}_{2}$ to give the corresponding diacetonide in excellent (92\%) yield following distillation. ${ }^{19,20}$ The iodide was then installed using standard conditions, the triphenylphosphine oxide was removed via trituration with $\mathrm{MeOH}$ and filtration, and the crude iodide $\mathbf{2 6}$ was treated with $\mathrm{HCl}$ and $\mathrm{MeOH}$ to afford triol 23, which readily crystallised from $\mathrm{MeOH} .{ }^{21}$ Though 2-steps longer than the protecting group free approach, (or one-step if diacetone galactose is commercially sourced), this second strategy gave an improved overall yield (72\%, from D-galactose) and had more efficient purification procedures as no column chromatography was required. Accordingly, we considered this the more appropriate route when preparing gram quantities of key intermediate iodide $\mathbf{2 3}$. With 23 in hand we proceeded to use our modified Vasella reductive amination protocol for the formation of linear alkenylamine 27. Applying these conditions to iodide $\mathbf{2 3}$ led to a smooth transformation into primary alkenylamine 27 (85\% yield), with only minor amounts $(\mathrm{ca} .10 \%)$ of the dimeric secondary amine observed. The two products, easily discernable via the ${ }^{13} \mathrm{C}$ NMR chemical shift of $\underline{\mathrm{NH}}_{2}$, can be readily separated by column chromatography. 
<smiles>CO[C@H]1O[C@H](CO)[C@@H](O)[C@H](O)[C@H]1O</smiles>

22

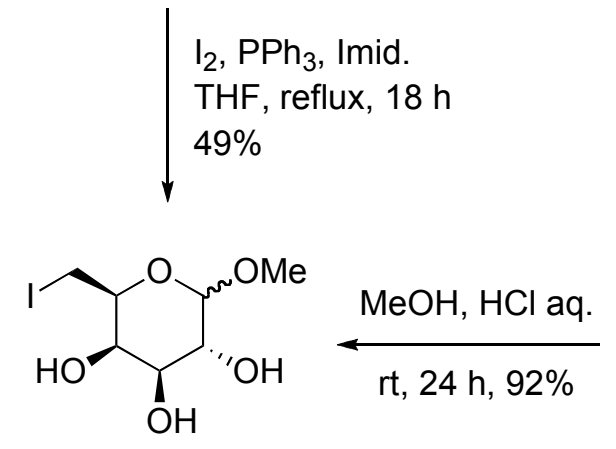

23<smiles>OC[C@H]1O[C@H](O)[C@H](O)[C@H](O)[C@@H]1O</smiles>

25

1) Acetone, $\mathrm{ZnCl}_{2}$ $\mathrm{H}_{2} \mathrm{SO}_{4}, \mathrm{rt}, 24 \mathrm{~h}, 92 \%$

2) $\mathrm{I}_{2}, \mathrm{PPh}_{3}$, Imid., THF reflux, $18 \mathrm{~h}, 85 \%$<smiles>CC1(C)O[C@@H]2[C@H](O[C@@H](CI)[C@H]3OC(C)(C)O[C@H]32)O1</smiles>

26

$\mathrm{Zn}, \mathrm{NaCNBH}_{3}$ $\mathrm{NH}_{3}, \mathrm{NH}_{4} \mathrm{OAc}$ $\mathrm{EtOH}$, reflux $18 \mathrm{~h}, 85 \%$<smiles>C=CC(O)C(O)C(O)CN</smiles>
27 $\underbrace{\mathrm{OH}}_{24}$<smiles>O=C1OC[C@H]2[C@@H](O)[C@H](O)[C@@H](O)CN12</smiles>
28a $56 \%$ 28b $25 \%$<smiles>CCO[Nb](O)(O)CO</smiles>

5<smiles>NCC1O[C@H](CI)C(O)C1O</smiles>

Scheme 6.4. Synthesis of DGJ 
Key in our strategy for the synthesis of DGJ was the applicability of the iodine-promoted carbamate annulation protocol to the formation of six membered azasugars. Though highly reliable for the formation of five membered azasugars, the formation of six membered rings includes hurdles such as the possible formation of furanose rings (e.g. 29 and 31, Scheme 6.4) and/or the formation of azasugar diastereomers (e.g. 28a, 28b). Given this, we spent some time optimising our carbamate annulation strategy to favour the formation of DGJ-precursor $\mathbf{2 8 a}$.

Following the original protocol, the first carbamate annulation reaction of alkenylamine 27 was carried out using 1.5 eq. $\mathrm{NaHCO}_{3}$ and iodine in water at room temperature (Entry 1, Table 6.1). This reaction was sluggish ( $>7$ days), therefore a saturated solution of $\mathrm{NaHCO}_{3}$ was used and the reaction mixture was warmed to $40{ }^{\circ} \mathrm{C}$ (Entry 2). This improved the reaction rate and gave a 3:1:1 ratio of 28a:28b:31. Next, in an attempted to favour the formation of 28a the more basic sodium carbonate salt was used, instead of sodium bicarbonate. To a solution of alkenylamine 27 in water, 20 eq. $\mathrm{Na}_{2} \mathrm{CO}_{3}$ and iodine were added, and the resulting mixture stirred for 3 days at rt (Entry 3), or 2 days at $40{ }^{\circ} \mathrm{C}$ (Entry 4 ). Concentration of the reaction mixtures in vacuo, and subsequent NMR analysis revealed that both conditions gave approximately a 3:1:1 mixture of 28a:28b:31, and no improvement in the yield of 28a was observed. It is interesting to note that reaction of alkenylamine 27 in a 1:1 mixture of sat. aq. $\mathrm{NaHCO}_{3}: \mathrm{MeOH}$ gave only a primary iodide product (Entry 5), thought it was difficult to conclusively determine whether this was furan 29 or the six membered iodide 30. In this example, it is presumed that the lack of carbamate product is due to the decreased solubility of carbonate in $\mathrm{MeOH}$. This result suggests that furan $\mathbf{3 1}$ is formed via reaction of alkenylamine 27 with $\mathrm{I}_{2}$ giving iodide 29 which subsequently reacts with ' $\mathrm{CO}_{2}$ ' to give the corresponding carbamate.

As cyclisation reactions forming five membered rings are kinetically favoured over cyclisations forming six membered rings, reaction of alkenylamine 27 with $\mathrm{I}_{2}$ and $\mathrm{NaHCO}_{3}$ was slower than cyclisation of the pentenylamines to form five membered azasugars. In addition, cyclisation of amine 27 also gave a 
considerable amount of ' $\mathrm{O}$ ' cyclised furan product 31. However in general, we were encouraged by the significant formation of the ' $N$ ' cyclised 6 membered ring product. Carbamate annulation to form the six membered azasugar also gave a mixture of diastereomers. (Discussions around stereochemical outcomes for the cyclisation reaction are at the end of Chapter 6.) Overall the best reaction outcome

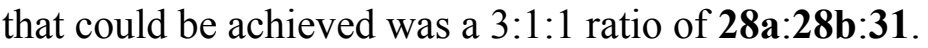

Table 6.1. Cyclisation of alkenylamine 27.

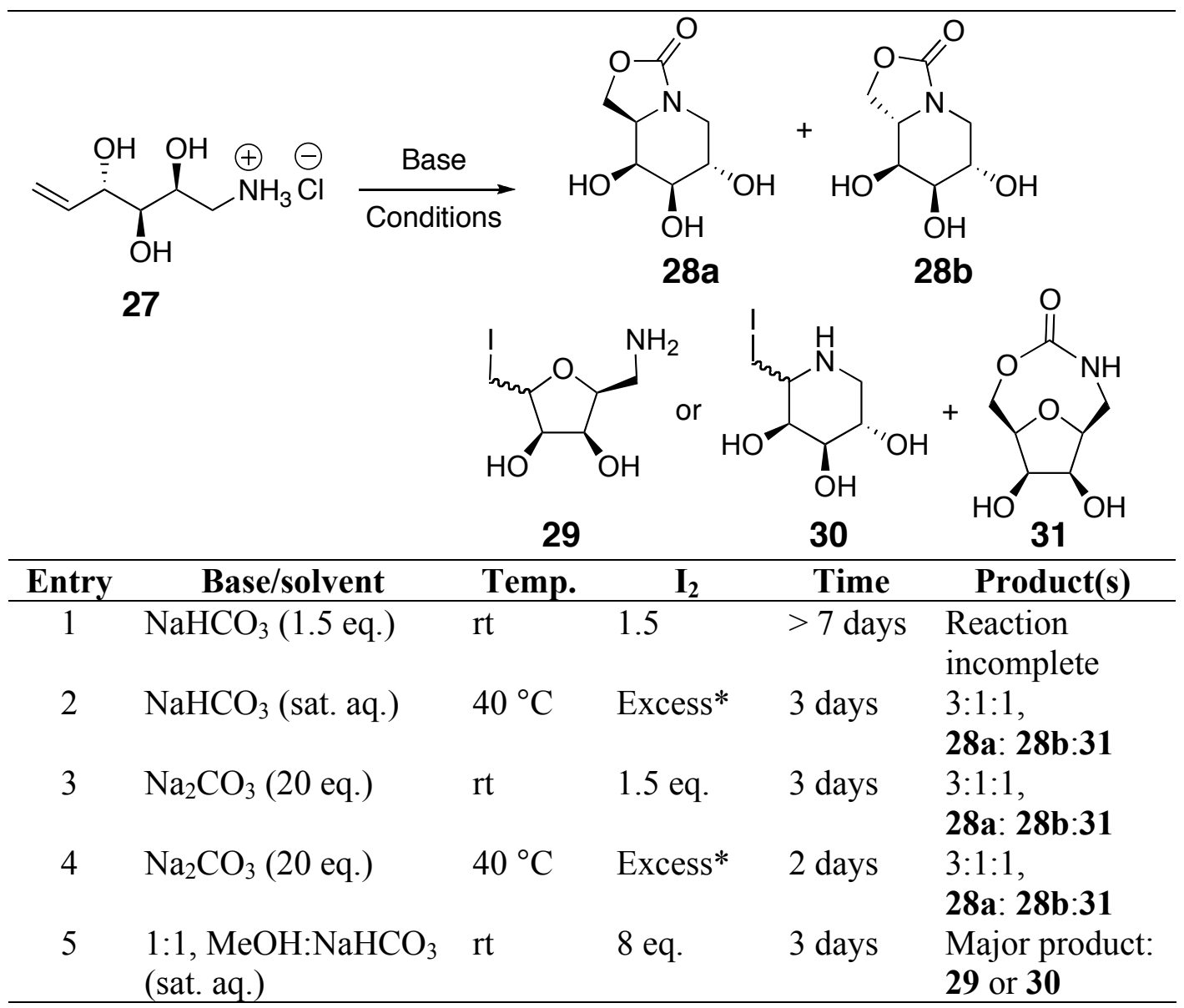

* Added in portions ( 5 x 1.5 eq. $)$

Diastereomers 28a and $\mathbf{2 8 b}$ could be separated using gradient silical gel chromatography (EtOAc/MeOH, 99/1 to 95/5, v/v), with $\mathbf{2 8 b}$ emerging from the column first. However, it was not possible to separate 28a from 31. Diastereomer 28a could be identified by the presence of a doublet of doublets at about $2.8 \mathrm{ppm}$ in the ${ }^{1} \mathrm{H}$ NMR, corresponding to $\mathrm{H}-1 \mathrm{~b}$. In contrast $\mathrm{H}-1 \mathrm{~b}$ of $\mathbf{2 8 b}$ appeared as a doublet at $3.2 \mathrm{ppm}$. Carbamate 28a was then hydrolysed using $\mathrm{NaOH}$ in $\mathrm{EtOH}$ to 
give DGJ (5) in 99\% yield. Overall DGJ was synthesised in six steps with a yield of $26 \%$, the shortest route to date.

With a successful strategy in place for the synthesis of DGJ (5) we wanted to apply our protecting group free methodology to the synthesis of 1,5-dideoxy-1,5imino-L-iditol (6) from D-glucose (Scheme 6.5). To this end, a solution of methyl $\alpha$-D-glucopyranoside (32) in THF was subjected to triphenylphosphine, imidazole and iodine to give the corresponding iodosugar 33 in $98 \%$ yield and, in contrast to galactose, without any observable by-products. The subsequent Vasella reductive amination reaction of iodosugar $\mathbf{3 3}$ also occurred smoothly to give linear alkenylamine 34 (93\% yield) with only a minor amount $(5 \%)$ of the secondary amine by-product. Alkenylamine 34 was then treated with $\mathrm{I}_{2}$ and $\mathrm{NaHCO}_{3}$ in anticipation that carbamate $\mathbf{3 8}$ would be synthesised, however, the only observed product contained a $\mathrm{CH}_{2} \mathrm{I}$ group as indicated by the presence of a methylene carbon at $-0.3 \mathrm{ppm}$ in the ${ }^{13} \mathrm{C}$ NMR. Extensive NMR $\left({ }^{1} \mathrm{H},{ }^{13} \mathrm{C}, \mathrm{COSY}, \mathrm{HMBC}\right.$, HSQC) and mass spectrometric analysis indicated that the product was either furan 35 or pyran 36. However while all carbon and proton NMR peaks could be assigned, the ring size could not be determined due to the lack of HMBC correlation between either 1 and 5 (indicating a six membered ring) or 2 and 5 (indicating a five membered ring) in $\mathrm{D}_{2} \mathrm{O}$ or $\mathrm{CD}_{3} \mathrm{OD}$. Attempts to purify the material by silical gel flash column chromatography or Dowex $\mathrm{H}^{+}$ion exchange lead to degradation of the material. Full characterisation was achieved via acetylation using acetic anhydride and pyridine. The spectral data for this compound revealed the presence of an NH peak in the ${ }^{1} \mathrm{H}$ NMR, which possessed a COSY correlation to both $\mathrm{H}-1 \mathrm{a}$ and $\mathrm{H}-1 \mathrm{~b}$ and no correlation to $\mathrm{H}-5$. This indicated that the acetylated product was indeed that of furan $\mathbf{3 7}$, as acetylation of pyran 36 would protect the amine centre, and no NH group would remain. Identifying furan 37 indicates that the product formed during $\mathrm{I}_{2}, \mathrm{NaHCO}_{3}$ promoted cyclisation was furan 35. In an attempt to favour ' $\mathrm{N}$ ' attack and form carbamate 38 a stronger base, $\mathrm{Na}_{2} \mathrm{CO}_{3}$, was used. After stirring at room temperature overnight no starting material remained, however, concentration and NMR analysis of the crude reaction mixture revealed that again only a furan product had been synthesised. This time, furan 39, formed via " $\mathrm{CO}_{2}$ " absorption on the primary amine, was observed as indicated by ${ }^{1} \mathrm{H}$ and ${ }^{13} \mathrm{C} \mathrm{NMR} \cdot{ }^{22,23} \mathrm{Next}$ 
the reaction temperature was varied. Alkenylamine 34 was stirred with $\mathrm{I}_{2}$, and sat. aq. $\mathrm{Na}_{2} \mathrm{CO}_{3}$ overnight at either $2{ }^{\circ} \mathrm{C}$ or reflux. Under these conditions there was still no observable carbamate formation, therefore this route to carbamate $\mathbf{3 8}$ was abandoned, as it appears that ' $N$ ' attack cannot be favoured for this alkenylamine.

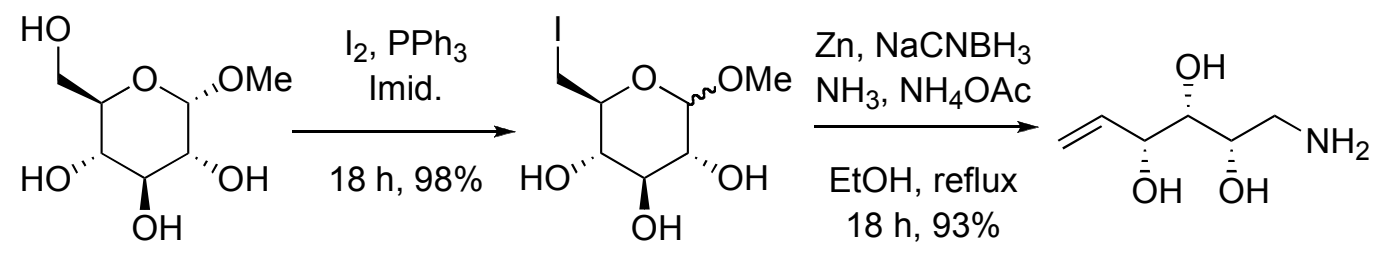
32 33

34

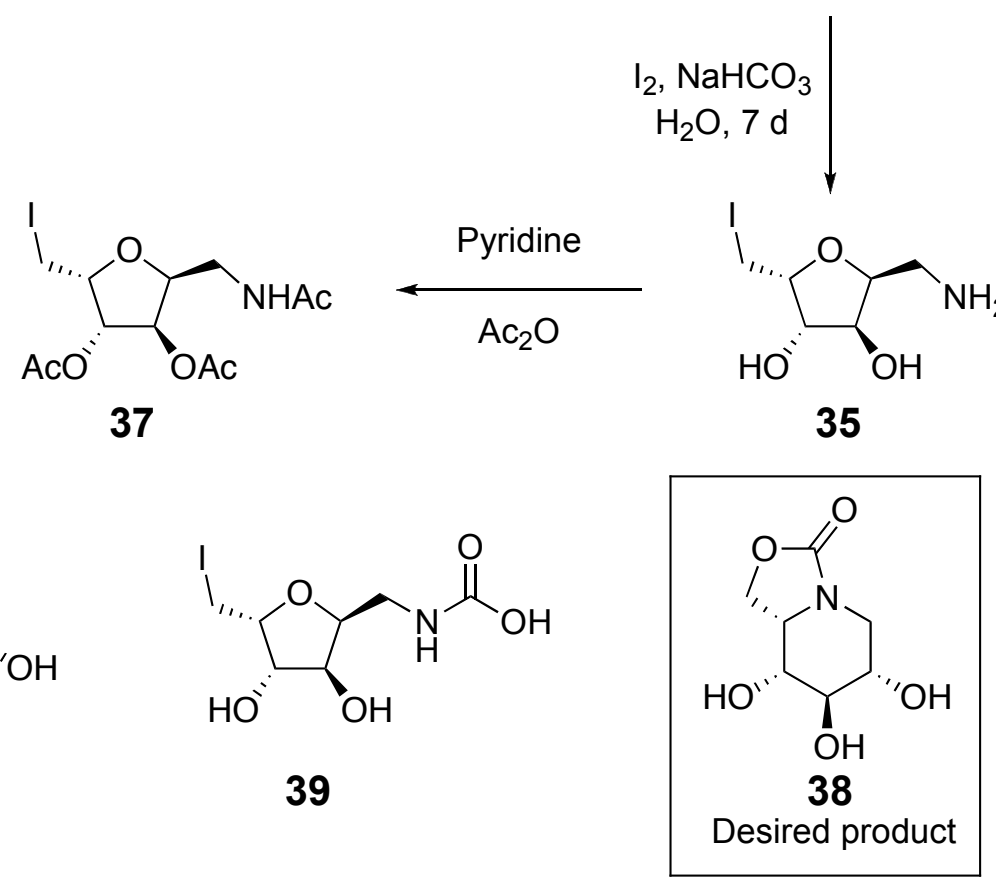

Scheme 6.5. Attempted synthesis of 1,5-dideoxy-1,5-imino-L-iditol (6) from methyl $\alpha$-D-glucopyranoside.

Given the success in forming carbamate 28a from alkenylamine 27 (Scheme 6.4), we envisaged synthesising carbamate 38 from alkenylamine 34 (Scheme 6.5). However, when alkenylamine $\mathbf{3 4}$ was subjected to iodocyclisation conditions only furan 35 was observed. Iodocyclisation reactions are irreversible and accordingly product formation is under kinetic (rather than thermodynamic) control. ${ }^{24}$ When a reaction is under kinetic control, product formation is dependant only on the relative activation energies of the respective transition states. Therefore, to understand the products formed from the cyclisation reactions of alkenylamines 
27 and 34 the transition state energies must be considered. The lower the transition state energy, the faster the reaction rate. A number of examples of intramolecular cyclisation reactions have served to establish a rough correlation between reaction rate and the size of the ring being formed. In general, intramolecular cyclisation reactions resulting in the formation of six membered rings are much slower than cyclisation reactions to form five membered rings. ${ }^{25}$ Mandolini and co-workers rationalised that the decrease in reaction rate is due to a combination of decreased entropy, resulting from a decrease in rotational freedom, and the relatively greater transition state strain energy, resulting from the 1,3-diaxial-type interactions in a six membered transition state. ${ }^{26}$ These $1,3-$ diaxial-type interactions are much less severe in five membered transition states. In addition, the nucleophile type also affects the rate of intramolecular cyclisation, this relationship is not as well studied as the effect of ring size. Although nitrogen is generally a better nucleophile than oxygen, there is evidence to suggest that intramolecular ring closure reactions with oxygen nucleophiles are faster than those with nitrogen nucleophiles. ${ }^{27}$ An explanation for this is that internal oxygen nucleophiles have increased directional flexibility compared to amine nucleophiles. A neutral amine nucleophile has three covalent bonds with a fixed orientation for the non-bonded electron pair, therefore, an amine nucleophile has specific directional requirements. In contrast, an oxygen nucleophile has two lone pairs this increases the directional flexibility and the reaction rate. ${ }^{27}$ Therefore, it is not so much that the formation of furan $\mathbf{3 5}$ is unusual, but more that the formation of carbamate 28a is extraordinary.

In the iodocyclisation of glucose-derived alkenylamine $\mathbf{3 4}$ there are four possible products that can theoretically be made (Scheme 6.6). According to the transition state models of Chamberlin et al., ${ }^{28}$ and Gouverneur and co-workers, ${ }^{29} \mathrm{O}$-in-plane transition states are favoured over H-in-plane transition states (discussed in subsequent paragraphs), therefore, the transition state energy of $\mathbf{B}$ is much greater than $\mathbf{A}(\mathbf{B}>>\mathbf{A})$ (Scheme 6.6). As mentioned, cyclisation reactions that afford five membered rings are much faster than those affording six membered rings. ${ }^{25,26}$ Accordingly, the transition state energies shown in Scheme 6.6 are as follows: $\mathbf{C}$ and $\mathbf{D}>\mathbf{A}$ and only five membered ring formation is observed (Scheme 6.5). As 
a result, the only product observed from the iodocyclisation of alkenylamine $\mathbf{3 4}$ is furan 35.<smiles>C=CC(O)C(O)C(O)CN</smiles>

\section{4}

Gluco<smiles>NCC1O[C@H](CO)C(O)C1[AlH]I</smiles>

A<smiles>NC[C@H]1O[C@H](I)[C@@H](O)[C@H]1O</smiles>

35<smiles>NCC1CC(O)C(O)CC1CO</smiles>

B

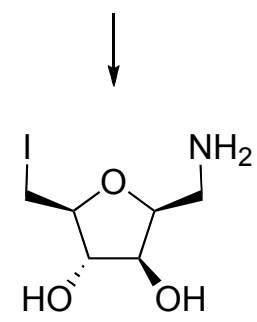<smiles>NC1C(O)C2C(O)C(O)C(I)C1C2I</smiles>

C<smiles>O[C@H]1CN[C@H](CI)[C@@H](O)[C@H]1O</smiles><smiles>NC1C(I)CC2(I)CC1C(O)C2O</smiles>

D<smiles>O[C@H]1CN[C@H](CI)[C@@H](O)[C@H]1O</smiles>

Scheme 6.6. Set of theoretical products and preceding transitions states in the iodocyclisation of glucose derived hexenylamine $\mathbf{3 4}$.

If we now turn our attention to the cyclisation of galactose derived alkenylamine 27 we must presume that the rate of the iodocyclisation reaction to form the five membered product $\mathbf{2 9 b}$ is, in this case, similar to the reaction rate leading to the six membered products $\mathbf{3 0 a}$ and $30 \mathbf{b}$ i.e. that transition states $\mathbf{B}, \mathbf{C}$, and $\mathbf{D}$ are roughly similar in energy (Scheme 6.7). (Again according to the transition state models by Chamberlin et al., ${ }^{28}$ and Gouverneur and co-workers ${ }^{29}$ we presume that the transition state energy of $\mathbf{A}$, where $\mathrm{H}$ is in plane, is much greater in energy than $\mathbf{B}$, when $\mathrm{O}$ is in plane $[\mathbf{A}>>\mathbf{B}]$ ). The question of reaction outcomes for alkenylamines $\mathbf{2 7}$ vs $\mathbf{3 4}$ then becomes why does the order of the relative transition state energies change for the two different substrates? In transition state B (Scheme 6.7) all of the ring substituents are in a relative cis configuration. This configuration involves a high degree of steric and electronic strain. In addition, all of the electron withdrawing substitutents are aligned, which is also destabilising. Overall these factors could elevate the transition state energy of $\mathbf{B}$ to such an 
extent that the five membered transition state $\mathbf{B}$ is no longer significantly lower in energy than the six membered transition states (C and $\mathbf{D})$. As a consequence both the five and six membered iodocyclisation products are observed. It is also worth mentioning that in transition states $\mathbf{C}$ and $\mathbf{D}$ (Scheme 6.7) the hydroxyl substitutents at positions two and three are equatorial. This also decreases the energies of these transitions states and contributes to the change in relative transition state energies.

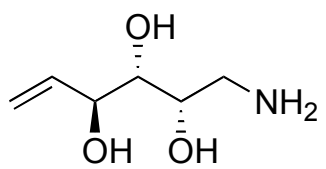

27

Galacto<smiles>NCC1O[C@H]2C=CC2(O)C1O</smiles>

A<smiles>NCC1O[C@H](I)C(O)C1O</smiles>

$29 a$<smiles>NCC1O[CH]C(I)C(O)C1O</smiles>

B

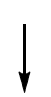<smiles>NC[C@H]1O[C@H](CI)[C@@H](O)[C@H]1O</smiles>

$29 b$<smiles>COC(=O)NC[C@H]1O[C@H]2COC(=O)O[C@H]2C1O</smiles>

31

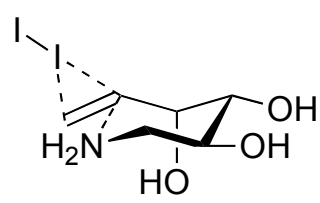

C<smiles>O[C@H]1CN[C@H](CI)[C@@H](O)[C@H]1O</smiles>

$30 a$<smiles>O=C1OC[C@H]2[C@H](O)[C@H](O)[C@@H](O)CN12</smiles>

28a<smiles>OC1C(I)=C2NCC(C1O)C(O)C2O</smiles>

D<smiles>O[C@H]1CN[C@H](CI)[C@@H](O)[C@H]1O</smiles>

$30 \mathrm{~b}$<smiles>O=C1OC[C@@H]2CN1C[C@@H](O)[C@H]2O</smiles>

28b

Scheme 6.7. Set of theoretical products and preceding transitions states in the iodocyclisation of galactose derived hexenylamine 27 . 


\section{Synthesis of six membered 1,2-dideoxyazasugars}

To further extend the carbamate annulation methodology, 2-deoxy hexoses were utilised, as these cannot form furan rings during the annulation, due to the absence of a C-2 hydroxyl. Accordingly, the synthesis of 4-epi-fagomine 7 began with the anomeric methylation of 2-dexoy-D-galactose (40) using $\mathrm{AcCl}$ and $\mathrm{MeOH}$ (Scheme 6.8). Under these conditions, only $40 \%$ of the desired methyl glycoside 41 was obtained, with the major products being the kinetically favoured furans. The reaction was not optimised at this stage, for it was deemed more important to first determine whether iodination of the unprotected methyl glycoside, to form 45, was plausible. Methyl glycoside 41 was subjected to iodination using $I_{2}$ and triphenylphosphine. Unfortunately, none of the desired methyl iodoglycoside $\mathbf{4 5}$ was observed and the major product was that of the bi-cyclic structure 42, in which nucleophilic attack of the 3-OH at C-6 occurs. This was not entirely unexpected given that similar results were observed en route to DGJ (Scheme 6.4). An alternate strategy for the preparation of iodoglycoside 45 was then developed, whereby 2-deoxy-D-galactose (40) was converted to the isopropylidene protected methyl glycoside $\mathbf{4 3}$ and subsequently iodinated to give protected methyl iodoglycoside 44 in a 73\% yield from 2-deoxy-D-galactose. Although the installation of the isopropylidene protecting group was not ideal, it only added one additional step to the synthesis. The isopropylidene protecting group could then be removed in acidic methanol to give the desired methyl iodoglycoside 45 to be used in the subsequent Vasella reductive amination. Gratifyingly, when 45 was refluxed with $\mathrm{Zn}, \mathrm{NH}_{3}, \mathrm{NH}_{4} \mathrm{OAc}$ and $\mathrm{NaCNBH}_{3}$, only the desired primary alkenylamine 46 was synthesised (99\% yield). 
<smiles>CC(C)(Cl)Cl</smiles>

40<smiles>CO[C@H]1C[C@@H](O)[C@H](O)[C@@H](CO)O1</smiles>

41
$\mathrm{I}_{2}, \mathrm{PPh}_{3}$

Imid.,THF

reflux, $18 \mathrm{~h}$<smiles>CO[C@H]1C[C@@H](O)[C@H]2CO[C@H]1O2</smiles>

42<smiles>COC(=O)COC(=O)COC(=O)OC(=O)OC</smiles><smiles>[Mg][TeH]</smiles><smiles>CO[C@H]1C[C@@H]2OC(C)(C)O[C@@H]2[C@H](CO)O1</smiles>

43

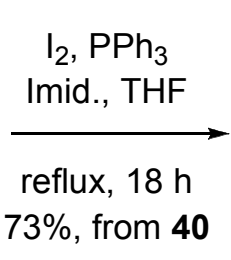

$73 \%$, from 40<smiles>CO[C@@H]1C[C@H]2OC(C)(C)O[C@@H]2C(CI)O1</smiles>

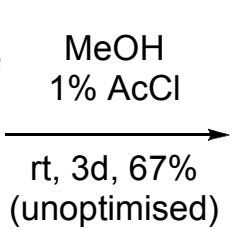

(unoptimised)<smiles>CO[C@H]1C[C@@H](O)[C@H](O)[C@@H](CI)O1</smiles>

45<smiles>O=C1OC[C@@H]2CN1CC[C@@H]2O</smiles><smiles>O=C1OC[C@@H]2[C@H](O)[C@H](O)CCN12</smiles>

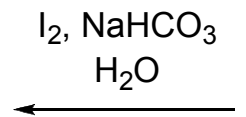<smiles>C=CC(O)C(O)CCN</smiles>

46

$47 a$

47b<smiles>[3H]O[C@H]1CCN[C@@H](CO)[C@@H]1O</smiles>

Scheme 6.8. Synthesis of 4-epi-fagomine 7.

With alkenylamine 46 in hand, we set about to cyclise this derivative. The cyclisation of alkenylamine 46, using excess $\mathrm{I}_{2}$ and $\mathrm{NaHCO}_{3}$ in water at $50{ }^{\circ} \mathrm{C}$ was complete after $24 \mathrm{~h}$. NMR analysis of the crude product mixture revealed a 
3:1 mixture of two products, which were determined to be diastereomers $47 \mathbf{a}$ and $47 b$.

Though outside the scope of my involvement in this project, it is interesting to note that subsequent experimentation by others in the group ${ }^{30}$ illustrated that $\mathbf{4 7 a}$ could be selectively synthesised ( $>20: 1,47 \mathbf{a}: 47 \mathbf{b})$ by stirring alkenylamine 46 in a solution sat. aq. $\mathrm{NaHCO}_{3}$ with $\mathrm{I}_{2}$ at $35{ }^{\circ} \mathrm{C}$ for 5 days giving carbamate 47a in a $86 \%$ yield. Carbamate 47 a was subsequently hydrolysed, using $\mathrm{NaOH}$ in ethanol, to provide 4-epi-fagomine (7) in a 92\% yield. Overall 4-epi-fagomine (7) was synthesised in six steps with a yield of 54\% yield, the most efficient total synthesis to date. The total synthesis of 4-epi-fagomine (7) has only been conducted twice before, once in 2003 (14\% yield over 7 steps), ${ }^{31}$ and in 2009 (35\% yield over 6 steps, from an advanced carbohydrate precursor). ${ }^{32}$

\section{Diastereoselectivity of the carbamate annulation reaction}

Perhaps one of the most remarkable features of our strategy for the synthesis of azasugars are the high yield and diastereoselectivity observed in the carbamate annulation reaction. The diastereoselectivity is in favour of the 3,4-cis (five membered) or 4,5-cis (six membered) isomers, as illustrated by the entries in Table 2. Cyclisation of the pentenylamines (Entries 1 to 4) gave the 3,4-cis carbamates exclusively, while cyclisation of hexenylamines (entries 5 and 6) favoured the 4,5-cis products, albeit with reduced selectivity. From these results it is apparent that the stereochemistry at the C-3 (five membered) or C-4 (six membered) position exerts stereocontrol on the cyclisation reaction and that this is unaffected by the chirality, or lack of chirality, at the adjacent centres. 
Table 2. Diastereoselectivity of iodine-promoted carbamate annulation.

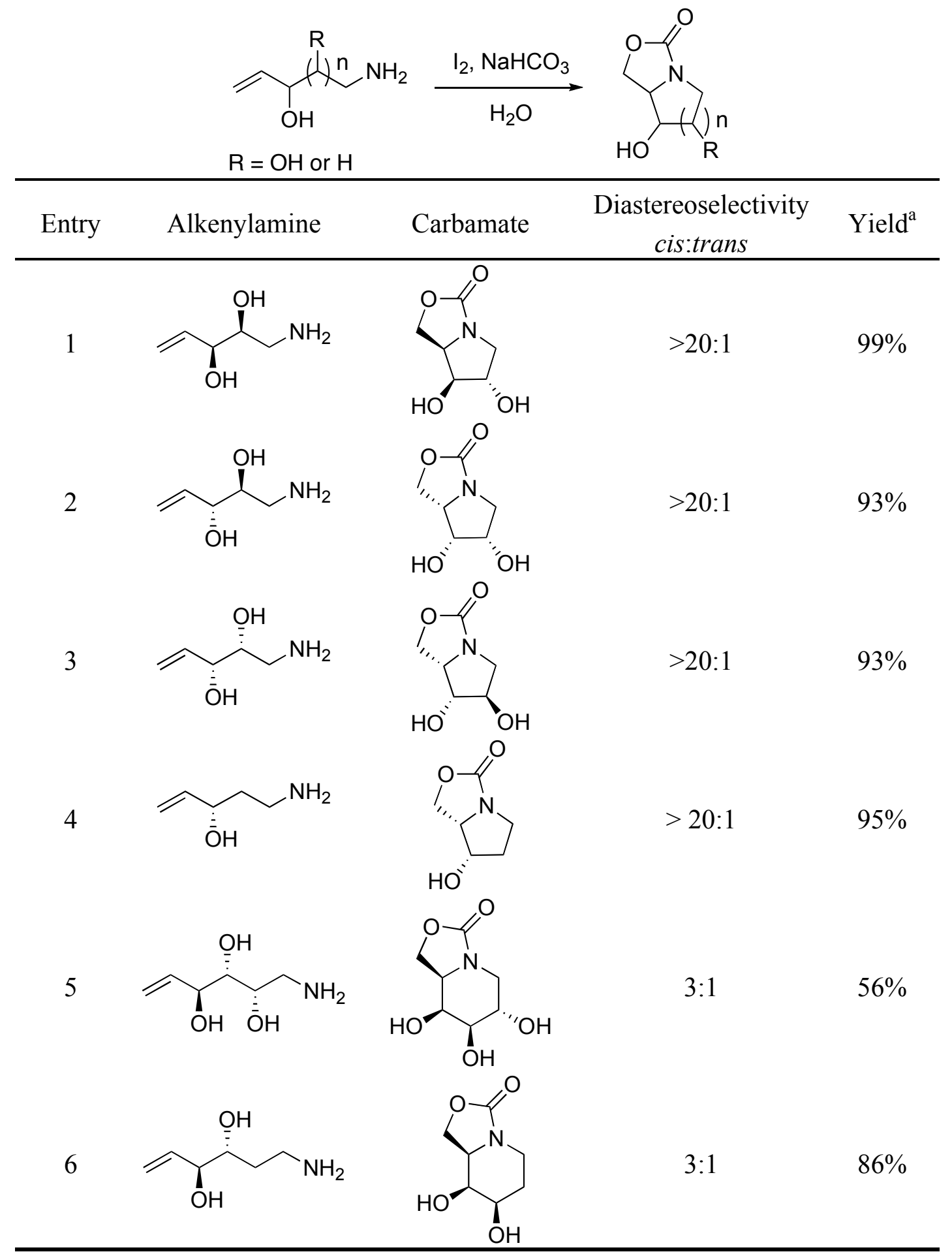

\footnotetext{
${ }^{\mathrm{a}}$ Isolated yield.
}

The high diastereoselectivity observed in these cyclisation reactions can be explained via a transition state model originally proposed by Chamberlin et al., ${ }^{28}$ which is in accordance with subsequent theoretical studies by Gouverneur and coworkers. ${ }^{29}$ Here it is proposed that during electrophilic cyclisations, the stereo 
directing hydroxyl can be positioned either in the plane of the double bond (A, Oin-plane), or almost perpendicular to that plane (B, H-in-plane) (Figure 2). Of these two transition states, A has minimal overlap between the electronwithdrawing $\sigma_{\mathrm{C}-\mathrm{O}}^{*}$ and reacting $\pi_{\mathrm{C}=\mathrm{C}}$ orbitals, thereby forming the lowest energy transition state. The H-in-plane conformation (B) has overlapping hydroxyl $\sigma_{\mathrm{C}-\mathrm{O}}^{*}$ and double bond $\pi_{\mathrm{C}=\mathrm{C}}$ orbitals, which destabilises the $\mathrm{I}_{2}-\pi$ complex and hence is disfavoured.

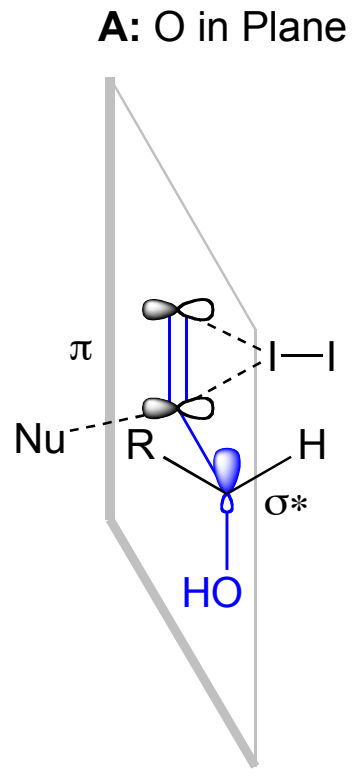

Favoured
B: $\mathrm{H}$ in plane

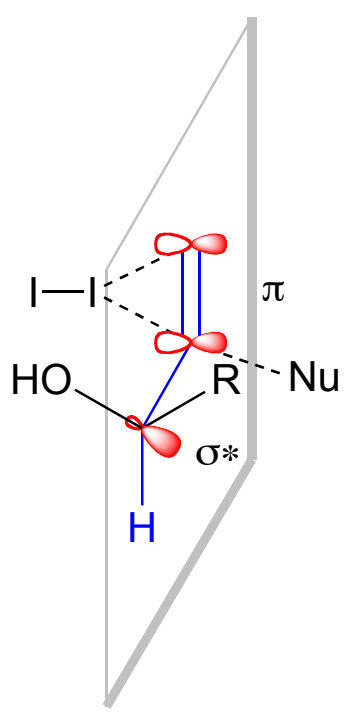

Disfavoured

Figure 2. $\mathrm{O}$ in Plane vs. $\mathrm{H}$ in plane.

During the cyclisation to form five membered azasugars, attack of the amine on the $I_{2}$-ethylene complex is envisioned to take place via a five membered ring transition structure, in which the ring nitrogen approaches the double bond in an ${ }^{\mathrm{N}} E$ (envelope) conformation and follows a Bürgi-Dunitz-like trajectory ${ }^{33}$ (Figure 3). Considering the two envelope transition states that can occur, it is apparent that where $\mathrm{O}$ is in plane, this transition state (A) leads to the 3,4-cis product, and the less favoured $\mathrm{H}$ in plane transition state (B) leads to the 3,4-trans product (Figure 3). 


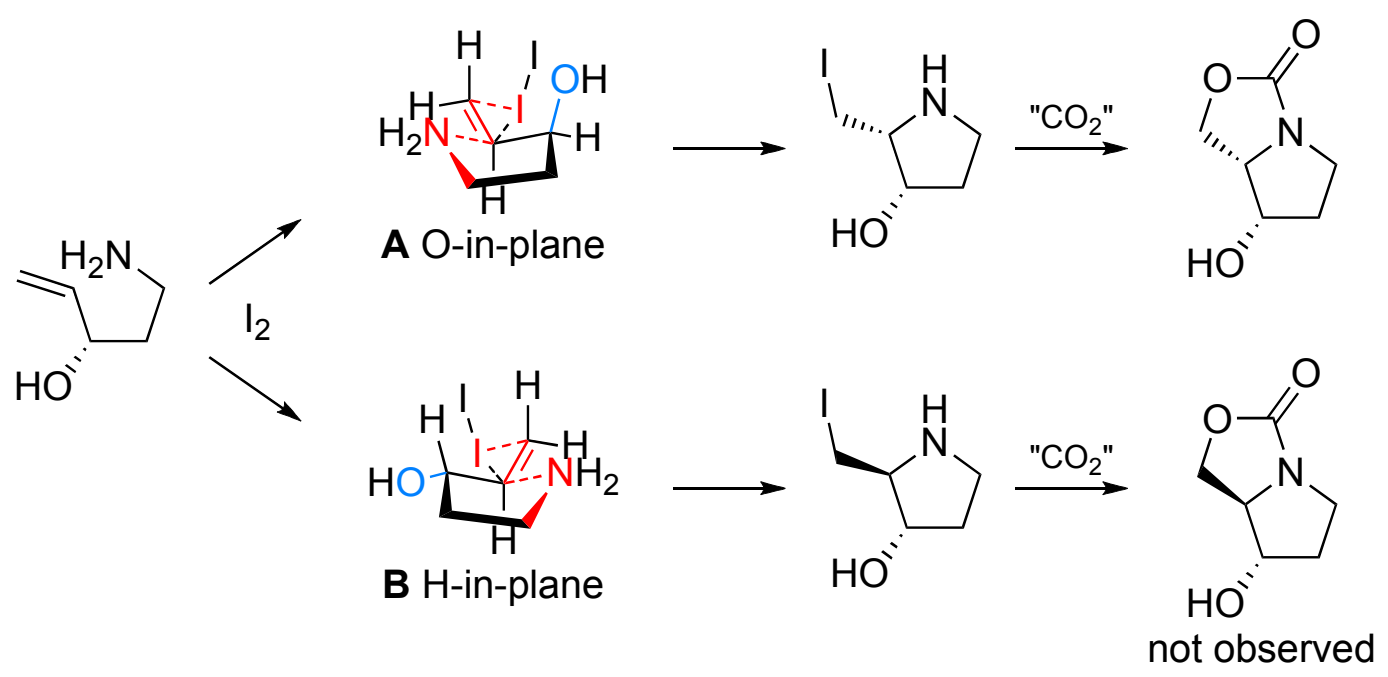

Figure 3. Proposed transition state for the iodine-promoted cyclisation of alkenylamines leading to the formation of five membered azasugar carbamates.

In the formation of six membered azasugars, the amine is likely to attack the $\mathrm{I}_{2}-$ ethylene complex via a six membered chair transition state (Figure 4). There are four possible chair transition states. Two in which $\mathrm{O}$ is in plane (A and $\mathbf{B})$, and two where $\mathrm{H}$ is in plane (C an $\mathbf{D})$. As discussed, the O-in-plane transition state is considered lower in energy, however, in the case of the six membered cyclisation, one of the O-in-plane transition states (A) leads to the 4,5-cis product, while the other (B) gives the trans product. Therefore, the stereochemical outcome of the reaction can no longer be accounted for solely on the basis of $\mathrm{O}$ vs. H-in-plane and it is necessary to also consider the position of the ring substituents in the transition state. During transition state A, the hydroxyl substituent is in an axial position, while the reacting double bond is in a more favored pseudo equatorial orientation. In contrast, during transition state $\mathbf{B}$ both the hydroxyl and the double bond substituents are in axial orientations, and are therefore subject to unfavourable 1,3-diaxial interactions. Transition state $\mathbf{A}$ is, therefore, likely to be lower in energy, and thus account for the observed 4,5-cis stereoselectivity observed during the six membered cyclisation. The 4,5-trans products can be formed from either transition state $\mathbf{B}$ or $\mathbf{C}$. In general it is difficult to predict which of these transition states lead to the trans product, however, based on our observations these transitions states are higher in energy than $\mathbf{A}$, and therefore the cis product predominates. 


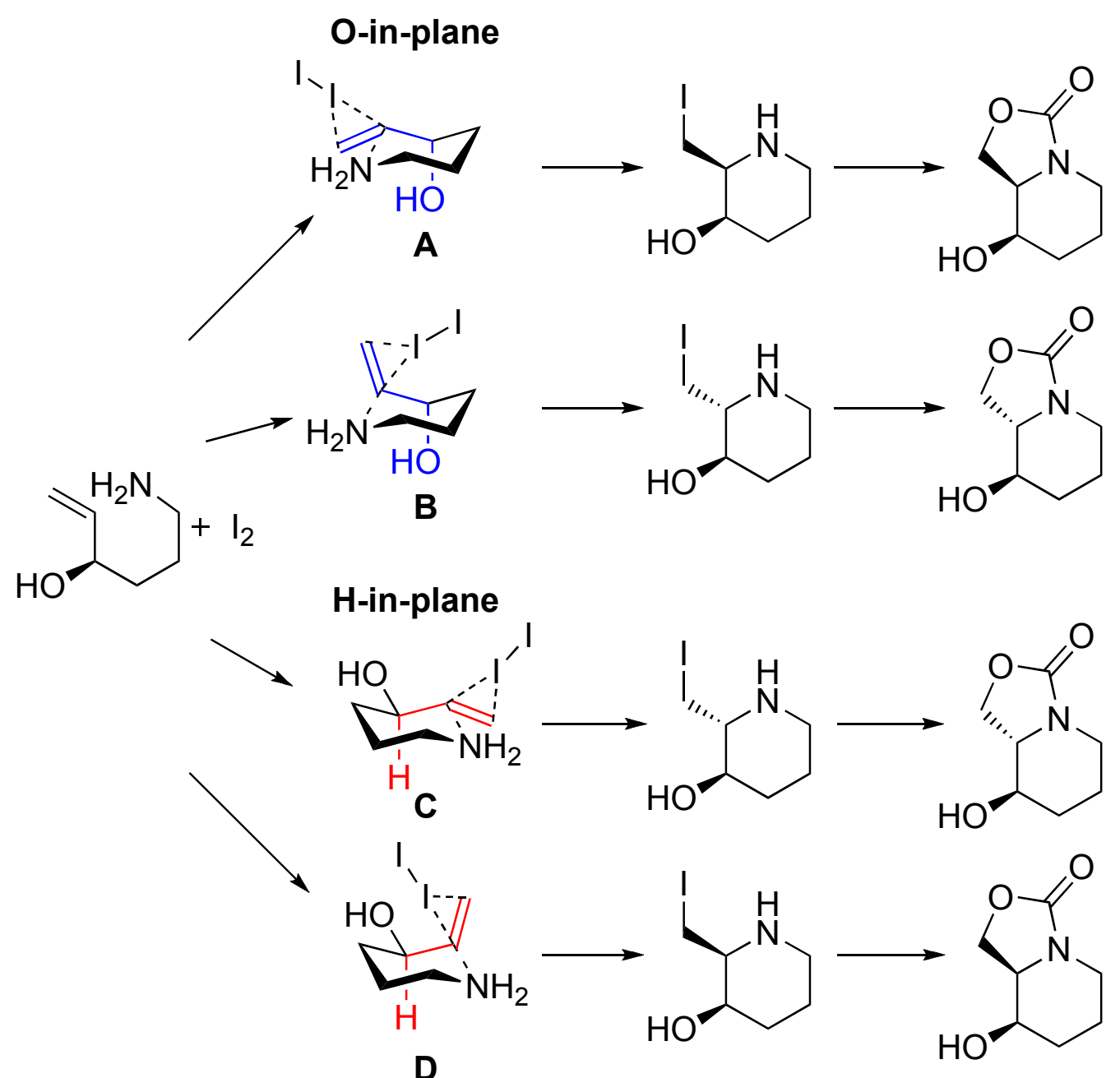

Figure 4. Proposed general transition state for iodine-promoted annulation for the formation of six membered azasugar carbamates.

\subsection{Conclusions}

In summary, we have achieved an efficient, high yielding and diastereoselective protecting group free strategy for the synthesis of a number of five membered azasugars and have extended this methodology for this synthesis of six membered azasugars. During the course of this work we have shed light on the mechanisms behind the remarkable stereoselectivity observed during the cyclisation reaction. In this chapter, each of the five membered azasugars were prepared in 5 steps, in good overall yield, and without the need for protecting groups. 1,4-Dideoxy-1,4imino-L-lyxitol (2) was synthesised in five steps, with an overall yield of 55\%. The overall yield for the formation of 1,4-dideoxy-1,4-imino-L-xylitol (3) was $54 \%$ and supersedes that of the next most efficient synthesis ( 3 steps, $48 \%$ total 
yield, commencing from 2,3,5-tri- $O$-benzyl-D -arabinofuranose). ${ }^{12}$ The overall yield for the synthesis of 1,2,4-trideoxy-1,4-imino-L-xylitol (4) was 48\% over the 5 steps. Progress was also made toward the synthesis of six membered azasugars. When galactose (Scheme 6.4) or 2-dexoygalactose (Scheme 6.8) were used as starting materials, alternative protecting group methodology was required for the synthesis of key methyl iodoglycosides. However, DGJ (5) was prepared in six steps with an overall $33 \%$ yield. This thesis highlights the progress made towards the synthesis of 4-epi-fagomine 7, which was subsequently completed. Unfortunately, when the alkenylamine derived from D -glucose was used as the starting material, only cyclisation to the furan was observed. Overall, this carbamate annulation methodology shows great potential for the synthesis of azasugars, however, competition between 5 and 6 membered cyclisation can limit the scope of the methodology.

\subsection{Experimental}

\section{General methods}

Unless otherwise stated all reactions were performed under atmospheric air. THF (Lab-Scan) was distilled from $\mathrm{LiAlH}_{4}$ prior to use. $\mathrm{H}_{2} \mathrm{O}, \mathrm{MeOH}$ (Pure Science), and EtOAc (Pure Science), were distilled prior to use. EtOH (absolute, Pure Science), DCM (LabServ), 30\% aqueous $\mathrm{NH}_{3}$ (J. T. Baker Chemical Co.), Ribose (BDH), arabinose (Sigma-Aldrich), lyxose (Sigma-Aldrich), methyl Dgalactopyranoside (Sigma), methyl D-glucopyranoside (Sigma), 2-deoxy-Dgalactose (Fluka), $\mathrm{AcCl}(\mathrm{B} \& \mathrm{M}), \mathrm{PPh}_{3}$ (Merck), imidazole (Aldrich), $\mathrm{I}_{2}$ (BDH), $\mathrm{NaCNBH}_{3}$ (Aldrich), $\alpha$-picoline borane (Aldrich), $\mathrm{NaOH}$ (Pure Science), and $\mathrm{NH}_{4} \mathrm{OAc}$ (AnalaR) were used as received. Zn dust was activated by the careful addition of conc. $\mathrm{H}_{2} \mathrm{SO}_{4}$ washed with $\mathrm{EtOH}(3 \mathrm{x})$ and hexanes $(3 \mathrm{x})$, and stored under dry hexanes. All solvents were removed by evaporation under reduced pressure. Reactions were monitored by TLC-analysis on Macherey-Nagel silica gel coated aluminium sheets $(0.20 \mathrm{~mm}$, silica gel 60) with detection by UVabsorption (254 nm), by spraying with $20 \% \mathrm{H}_{2} \mathrm{SO}_{4}$ in $\mathrm{EtOH}$ followed by charring at $\sim 150{ }^{\circ} \mathrm{C}$, by dipping in $\mathrm{I}_{2}$ in silica, or by spraying with a solution of ninhydrin in EtOH followed by charring at $\sim 150{ }^{\circ} \mathrm{C}$. Column chromatography was 
performed on Pure Science silica gel (40-63 micron). Dowex ${ }^{\circledR}$ W50-X8 acidic resin (Sigma) and Dowex ${ }^{\circledR}$ 1X4-50 basic resin (Sigma) were used for ion exchange chromatography and HP-20 (Supelco) for reverse phase chromatography. High-resolution mass spectra were recorded on a Waters Q-TOF Premier $^{\mathrm{TM}}$ Tandem Mass Spectrometer using positive electro-spray ionisation. Optical rotations were recorded using a Perkin-Elmer 241 polarimeter at the sodium D-line. Infrared spectra were recorded as thin films using a Bruker Tensor 27 FTIR spectrometer, equipped with an Attenuated Total Reflectance (ATR) sampling accessory, and are reported in wave numbers $\left(\mathrm{cm}^{-1}\right)$. Nuclear magnetic resonance spectra were recorded at $20^{\circ} \mathrm{C}$ in $\mathrm{D}_{2} \mathrm{O}, \mathrm{CD}_{3} \mathrm{OD}$ or $\mathrm{CDCl}_{3}$ using either a Varian Unity-INOVA operating at $300 \mathrm{MHz}$ or a Varian Unity operating at 500 MHz. Chemical shifts are given in ppm $(\delta)$ relative to tetramethylsilane. NMR peak assignments were made using COSY, HSQC and HMBC 2D experiments.

For the synthesis of compounds $10(5), 15(7), 20(9)$, and 34 (15) in chapter 6 please refer to chapter 5 , numbering for these compounds in chapter 5 is in brackets.

\section{General procedure for the synthesis of methyl furanosides.}

To a solution of pentose $(150 \mathrm{mg}, 1 \mathrm{mmol})$ in $\mathrm{MeOH}(5 \mathrm{~mL}), \mathrm{AcCl}(15 \mu \mathrm{L})$ was added and the reaction was stirred at room temperature for $18 \mathrm{~h}$. The reaction was quenched by the addition of Dowex $\left(\mathrm{OH}^{-}\right)$, filtered and concentrated. The resulting oil was purified by flash chromatography to give the pure methyl furanosides.

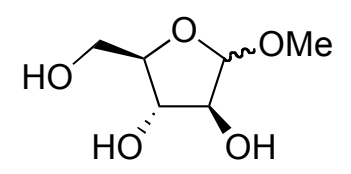

Methyl D-arabinofuranoside (13). By subjecting Darabinose 12 (20.1 g, $134 \mathrm{mmol})$ to the general procedure for the synthesis of methyl furanosides, methyl D-arabinofuranoside (13) was isolated as a colourless oil (19.1 g, $118 \mathrm{mmol}, 88 \%) . \mathrm{R}_{f}=0.48$ and 0.36 for $\alpha$ and $\beta$ respectively $(10 \%$ $\mathrm{MeOH}$ in EtOAc); $[\alpha]_{\mathrm{D}}{ }^{19}=+91.0(c=1.0, \mathrm{MeOH})$; IR (film), 3356, 2924, 2481, $1455,1119,972,824 \mathrm{~cm}^{-1} ;{ }^{1} \mathrm{H}$ NMR $\left(500 \mathrm{MHz}, \mathrm{CD}_{3} \mathrm{OD}\right) \delta 4.88\left(\mathrm{~d}, J_{1,2}=1.5 \mathrm{~Hz}\right.$, $1 \mathrm{H}, \mathrm{H}-1 \alpha), 3.94\left(\mathrm{dd}, J_{1,2}=1.5, J_{2,3}=3.5 \mathrm{~Hz}, 1 \mathrm{H}, \mathrm{H}-2 \alpha\right), 3.91\left(\mathrm{ddd}, J_{4,5 \mathrm{a}}=3.3\right.$, 
$\left.J_{4,5 \mathrm{~b}} 5.3, J_{3,4}=6.1 \mathrm{~Hz}, 1 \mathrm{H}, \mathrm{H}-4 \alpha\right), 3.83\left(\mathrm{dd}, J_{2,3}=1.5, J_{3,4}=6.1 \mathrm{~Hz}, 1 \mathrm{H}, \mathrm{H}-3 \alpha\right)$, $3.75\left(\mathrm{dd}, J_{4,5 \mathrm{a}}=3.3, J_{5 \mathrm{a}, 5 \mathrm{~b}}=11.6 \mathrm{~Hz}, 1 \mathrm{H}, \mathrm{H}-5 \mathrm{a \alpha}\right), 3.64\left(\mathrm{dd}, J_{4,5 \mathrm{~b}}=5.3, J_{5 \mathrm{a}, 5 \mathrm{~b}}=11.6\right.$ $\mathrm{Hz}, 1 \mathrm{H}, \mathrm{H}-5 \mathrm{~b} \alpha$ ), 3.37 (s, 3H, OMe); ${ }^{13} \mathrm{C}$ NMR (125 MHz, CD $\left.3 \mathrm{OD}\right) \delta 109.2$ (C1), 84.1 (C4), 82.0 (C2), 77.3 (C3), 61.6 (C5), 53.9 (OMe); HRMS(ESI) m/z calcd. for $\left[\mathrm{C}_{6} \mathrm{H}_{12} \mathrm{O}_{5}+\mathrm{Na}\right]^{+}:$187.0577, obsd.: 187.0581 .

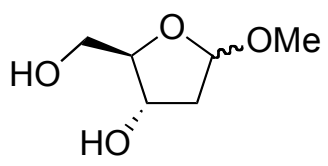

Methyl 2-deoxy- $\alpha / \beta$-D-riboside (18). To a solution of 2deoxy-D-ribose (17) (200 mg, $1.5 \mathrm{mmol})$ in methanol $(7.5 \mathrm{~mL}) \mathrm{AcCl}(75 \mu \mathrm{L})$ was added and the solution stirred $15 \mathrm{~min}$. at room temperature. The reaction was quenched by the addition of Dowex $\left(\mathrm{OH}^{-}\right)$, filtered and concentrated. The resulting oil was purified by gradient flash chromatography (EtOAc $\rightarrow$ $\mathrm{MeOH} /$ EtOAc, 1/9, v/v) to give methyl furanoside 18 (203 mg, $1.37 \mathrm{mmol}, 91 \%$ ). $\mathrm{R}_{f}=0.7\left(15 \% \mathrm{MeOH}\right.$ in EtOAc); $[\alpha]_{\mathrm{D}}{ }^{18}=+5.20$ (c = 1.0, EtOH); IR (film), 3372, 2942, 1448, 1358, 1031, $1009 \mathrm{~cm}^{-1} ;{ }^{1} \mathrm{H}$ NMR $\left(500 \mathrm{MHz}, \mathrm{CDCl}_{3}\right) \delta 5.17$ (dd, $J_{1,2 \mathrm{a}}$ $\left.=2.1, J_{1,2 \mathrm{~b}}=5.5 \mathrm{~Hz}, 1 \mathrm{H}, \mathrm{H}-1 \beta\right), 5.12\left(\mathrm{dd}, J_{1,2 \mathrm{~b}}=2.3, J_{1,2 \mathrm{a}}=4.4 \mathrm{~Hz} 1 \mathrm{H}, \mathrm{H}-1 \alpha\right)$,

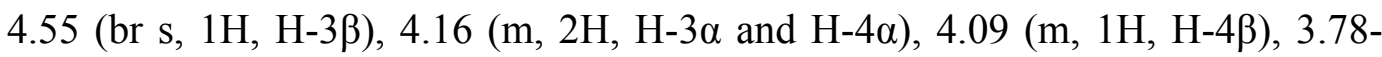
3.59 (m, 4H, H-5a $\alpha$, H-5b $\alpha$, H-5a $\beta$, and H-5b $\beta$ ), 3.41 (s, 3H, OMe- $\alpha$ ), 3.40 (s, 3H, OMe- $\beta$ ), $2.32\left(\mathrm{ddd}, J_{1,2 \mathrm{a}}=2.3, J_{2 \mathrm{a}, 3}=4.9, J_{2 \mathrm{a}, 2 \mathrm{~b}}=14.0 \mathrm{~Hz}, 1 \mathrm{H}, \mathrm{H}-2 \mathrm{a} \alpha\right), 2.18-2.09$ (m, 2H, H-2ba, H-2a $\beta), 2.05-2.02$ (m, 1H, H-2b $\beta) ;{ }^{13} \mathrm{C}$ NMR (125 MHz, $\mathrm{CDCl}_{3}$ )

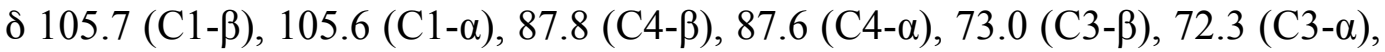
63.6 (C5- $\beta$ ), 63.3 (C5- $\alpha$ ), 55.6 (OMe- $\beta$ ), 55.0 (OMe- $\alpha$ ), 42.8 (C2- $\beta$ ), 41.7 (C2- $\alpha$ ); HRMS(ESI) $m / z$ calcd. for $\left[\mathrm{C}_{6} \mathrm{H}_{12} \mathrm{O}_{4}+\mathrm{Na}\right]^{+}: 171.0628$, obsd.:171.0631.

\section{General procedure for the synthesis of methyl iodo-glycosides.}

To a solution of methyl glycoside $(164 \mathrm{mg}, 1 \mathrm{mmol})$ in dry THF $(5.5 \mathrm{~mL})$ under an atmosphere of $\mathrm{N}_{2}, \mathrm{PPh}_{3}(393 \mathrm{mg}, 1.5 \mathrm{mmol})$ and imidazole (136 mg, $2 \mathrm{mmol}$ ) were added. $\mathrm{I}_{2}(380 \mathrm{mg}, 1.5 \mathrm{mmol})$ in dry THF $(1.5 \mathrm{~mL})$ was cannulated into the reaction vessel. The reaction was refluxed for $2 \mathrm{~h}$, then cooled, filtered and concentrated. The product was taken up in Petroleum ether/EtOAc, 3/1, v/v, and filtered through a silica plug to removed excess iodine, then purified by column chromatography on reverse phase HP-20 beads $(\mathrm{MeOH} /$ water, 5/1, v/v) to give the methyl iodo-D-glycosides. 
<smiles>CO[C@H]1O[C@H](CI)[C@@H](O)[C@H]1O</smiles>

$\mathrm{HO} \quad$ "OH Methyl 5-deoxy-5-iodo- $\boldsymbol{\alpha} / \boldsymbol{\beta}$-D-riboside (9). By subjecting Dribose $(8)(1.02 \mathrm{~g}, 6.22 \mathrm{mmol})$ to the general procedure for the formation of methyl iodo-glycosides, riboside $\mathbf{9}$ was obtained as an amorphous white solid in a 1:9 ratio of $\alpha$ - and $\beta$ - anomers $(1.14 \mathrm{~g}, 4.15 \mathrm{mmol}, 67 \%) . \mathrm{R}_{f}=0.63$ $\left(\right.$ EtOAc/MeOH, 9/1, v/v); $[\alpha]_{\mathrm{D}}{ }^{19}=-61.0\left(c=0.8, \mathrm{CHCl}_{3}\right) ;$ IR (film) 3423, 1218, $770 \mathrm{~cm}^{-1} .{ }^{1} \mathrm{H}$ NMR $\left(500 \mathrm{MHz}, \mathrm{CDCl}_{3}\right) \delta 4.87(\mathrm{~s}, 1 \mathrm{H}, \mathrm{H}-1), 4.23\left(\mathrm{dd}, J_{2,3}=5.0\right.$, $\left.J_{3,4}=5.9 \mathrm{~Hz}, 1 \mathrm{H}, \mathrm{H}-3\right), 4.12\left(\mathrm{~d}, J_{2,3}=5.0 \mathrm{~Hz}, 1 \mathrm{H}, \mathrm{H}-2\right), 4.06\left(\mathrm{dt}, J_{4,5 \mathrm{~b}}=7.4, J_{3,4}=\right.$ $\left.J_{4,5 \mathrm{a}}=5.9 \mathrm{~Hz}, 1 \mathrm{H}, \mathrm{H}-4\right), 3.39(\mathrm{~s}, 3 \mathrm{H}, \mathrm{OMe}), 3.35\left(\mathrm{dd}, J_{4,5 \mathrm{a}}=5.9, J_{5 \mathrm{a}, 5 \mathrm{~b}}=10.1 \mathrm{~Hz}\right.$, $1 \mathrm{H}, \mathrm{H}-5 \mathrm{a}), 3.30\left(\mathrm{dd}, J_{4,5 \mathrm{~b}}=7.4, J_{5 \mathrm{a}, 5 \mathrm{~b}}=10.1 \mathrm{~Hz}, 1 \mathrm{H}, \mathrm{H}-5 \mathrm{~b}\right) 2.8$ (br s, 1H, OH), 2.7 (br s, 1H, OH); ${ }^{13} \mathrm{C}$ NMR (125 MHz, $\mathrm{CDCl}_{3}$ ) $\delta 108.2$ (C1), 82.8 (C4), 75.7 (C2), 75.6 (C3), 55.3 (OMe), 7.9 (C5); HRMS(ESI) $m / z$ calcd. for $\left[\mathrm{C}_{6} \mathrm{H}_{11} \mathrm{O}_{4} \mathrm{I}+\mathrm{Na}\right]^{+}$: 296.9594, obsd.: 296.9595 .

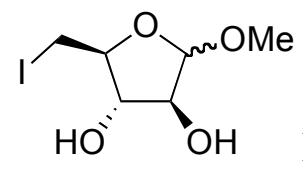

Methyl 5-deoxy-5-iodo-D-arabinofuranoside (14). By subjecting methyl D-arabinoside $13(4.20 \mathrm{~g}, 28 \mathrm{mmol})$ to the general procedure for the synthesis of methyl iodo-glycosides, arabinoside $\mathbf{1 4}$ was obtained as a colourless oil (5.62 g, $20.5 \mathrm{mmol}, 73 \%) . \mathrm{R}_{f}=0.60\left(15 \% \mathrm{MeOH}\right.$ in EtOAc); $[\alpha]_{\mathrm{D}}{ }^{20}$ $=+37.0\left(c=2.2, \mathrm{CHCl}_{3}\right)$; IR (film), 3435, 1216, $770 \mathrm{~cm}^{-1} ;{ }^{1} \mathrm{H}$ NMR $(500 \mathrm{MHz}$, $\left.\mathrm{CDCl}_{3}\right): \delta 4.96(\mathrm{~s}, 1 \mathrm{H}, \mathrm{H}-1 \alpha), 4.86\left(\mathrm{~d}, J_{1 \beta, 2 \beta}=4.6 \mathrm{~Hz}, 1 \mathrm{H}, \mathrm{H}-1 \beta\right), 4.17\left(\mathrm{~d}, J_{2 \alpha, 3 \alpha}=\right.$ $1.9 \mathrm{~Hz}, 1 \mathrm{H}, \mathrm{H}-2 \alpha), 4.12\left(\mathrm{dd}, J_{1 \beta, 2 \beta}=4.6, J_{2 \beta, 3 \beta}=7.0 \mathrm{~Hz}, 1 \mathrm{H}, \mathrm{H}-2 \beta\right), 4.07$ (dt, $J_{3 \alpha, 4 \alpha}$ $\left.=3.9, J_{4 \alpha, 5 \mathrm{a} \alpha}=J_{4 \alpha, 5 \mathrm{a} \alpha}=5.8 \mathrm{~Hz}, 1 \mathrm{H}, \mathrm{H}-4 \alpha\right), 4.04\left(\mathrm{ddd}, J_{3 \beta, 4 \beta}=3.2, J_{4 \beta, 5 \mathrm{a} \beta}=6.1\right.$, $\left.J_{4 \beta, 5 \mathrm{~b} \beta}=7.0 \mathrm{~Hz}, 1 \mathrm{H}, \mathrm{H}-4 \beta\right), 3.95\left(\mathrm{dd}, J_{3 \beta, 4 \beta}=3.2, J_{2 \beta, 3 \beta}=7.0 \mathrm{~Hz}, 1 \mathrm{H}, \mathrm{H}-3 \beta\right), 3.91$ $\left(\mathrm{dd}, J_{2 \alpha, 3 \alpha}=1.9, J_{3 \alpha, 4 \alpha}=3.9 \mathrm{~Hz}, 1 \mathrm{H}, \mathrm{H}-3 \alpha\right) 3.48$ (s, 3H, $\left.\beta-\mathrm{OMe}\right), 3.42$ (s, 3H, $\alpha-$ OMe), $3.41\left(\mathrm{dd}, J_{4 \alpha, 5 \mathrm{a} \alpha}=5.8, J_{5 \mathrm{a} \alpha, 5 \mathrm{~b} \alpha}=10.5 \mathrm{~Hz}, 1 \mathrm{H}, \mathrm{H}-5 \mathrm{a} \alpha\right), 3.37\left(\mathrm{dd}, J_{4 \alpha, 5 b \alpha}=5.8\right.$, $\left.J_{5 \mathrm{a} \alpha, 5 \mathrm{~b} \alpha}=10.5 \mathrm{~Hz}, 1 \mathrm{H}, \mathrm{H}-5 \mathrm{~b} \alpha\right), 3.33\left(\mathrm{dd}, J_{4 \beta, 5 \mathrm{a} \beta}=6.1, J_{5 \mathrm{a} \beta, 5 \mathrm{~b} \beta}=10.0 \mathrm{~Hz}, \mathrm{H}-5 \mathrm{a} \beta\right)$, $3.30\left(\mathrm{dd}, J_{4 \beta, 5 \mathrm{~b} \beta}=7.0, J_{5 \mathrm{a} \beta, 5 \mathrm{~b} \beta}=10.0 \mathrm{~Hz}, \mathrm{H}-5 \mathrm{a} \alpha\right) ;{ }^{13} \mathrm{C} \mathrm{NMR}\left(125 \mathrm{MHz}, \mathrm{CDCl}_{3}\right) \delta$ $108.9(\mathrm{C} 1-\alpha), 101.9(\mathrm{C} 1-\beta), 84.7$ (C4- $\alpha), 81.5(\mathrm{C} 3-\beta), 81.0(\mathrm{C} 3-\alpha), 80.8(\mathrm{C} 2-\alpha)$, 80.6 (C4- $\beta$ ), 78.6 (C2- $\beta$ ), 55.6 (C6- $\beta$ ), 55.2 (C6- $\alpha$ ), 8.0 (C5- $\beta$ ), 6.6 (C5- $\alpha$ ); HRMS(ESI) $m / z$ calcd. for $\left[\mathrm{C}_{6} \mathrm{H}_{11} \mathrm{O}_{4} \mathrm{I}+\mathrm{Na}\right]^{+}:$296.9594, obsd.: 296.9598. 
<smiles>CO[C@H]1CC[C@@H](CI)O1</smiles>

HO" Methyl 2,5-dideoxy-5-iodo- $\alpha / \beta$-D-riboside (19). By subjecting methyl 2-deoxy- $\alpha / \beta$-D-riboside $(\mathbf{1 8}, 201 \mathrm{mg}, 1.36 \mathrm{mmol})$ to the general procedure for the synthesis of methyl iodo-glycosides, except stirring at room temperature for $18 \mathrm{~h}$ (rather than $2 \mathrm{~h}$ at reflux), methyl 2,5-iodo-D-riboside 19 was obtained as an oil (257 mg, $0.99 \mathrm{mmol}, 73 \%) . \mathrm{R}_{f}=0.6\left(15 \% \mathrm{MeOH}\right.$ in EtOAc); $[\alpha]_{\mathrm{D}}{ }^{17}=-2.05$ (c = 1.0, $\mathrm{CHCl}_{3}$ ); IR (film), 3475, 2986, 2874, 2829, 1416, 1441, 1062, $1016 \mathrm{~cm}^{-1}$; ${ }^{1} \mathrm{H}$ NMR $\left(500 \mathrm{MHz}, \mathrm{CDCl}_{3}\right) \delta 5.14\left(\mathrm{~d}, J_{1,2 \mathrm{~b}}=4.5 \mathrm{~Hz}, 1 \mathrm{H}, \mathrm{H}-1 \beta\right), 5.12\left(\mathrm{dd}, J_{1,2 \mathrm{~b}}=\right.$ $\left.1.6, J_{1,2 \mathrm{a}}=5.2 \mathrm{~Hz} 1 \mathrm{H}, \mathrm{H}-1 \alpha\right), 4.49\left(\mathrm{ddd}, J_{2 \mathrm{a}, 3}=4.1, J_{2 \mathrm{~b}, 3}=6.6, J_{3,4}=10.7 \mathrm{~Hz}, 1 \mathrm{H}\right.$,

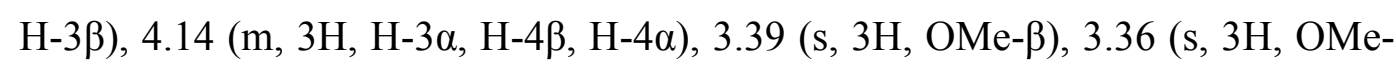
$\alpha), 3.32\left(\mathrm{dd}, J_{4,5 \mathrm{a}}=5.8, J_{5 \mathrm{a}, 5 \mathrm{~b}}=9.5 \mathrm{~Hz}, 1 \mathrm{H}, \mathrm{H}-5 \mathrm{a} \beta\right), 3.26\left(\mathrm{dd}, J_{5 \mathrm{a}, 4}=4.9, J_{5 \mathrm{a}, 5 \mathrm{~b}}=\right.$ $10.5 \mathrm{~Hz}, 1 \mathrm{H}, \mathrm{H}-5 \mathrm{a} \alpha), 3.20\left(\mathrm{t}, J_{5 \mathrm{a}, 5 \mathrm{~b}}=J_{4,5 \mathrm{~b}}=9.5 \mathrm{~Hz}, 1 \mathrm{H}, \mathrm{H}-5 \mathrm{~b} \beta\right), 3.18\left(\mathrm{dd}, J_{4,5 \mathrm{~b}}=\right.$ $\left.6.3, J_{5 \mathrm{a}, 5 \mathrm{~b}}=10.5 \mathrm{~Hz}, 1 \mathrm{H}, \mathrm{H}-5 \mathrm{~b} \alpha\right), 2.32\left(\mathrm{ddd}, J_{1,2 \mathrm{~b}}=1.6, J_{2 \mathrm{~b}, 3}=6.8, J_{2 \mathrm{a}, 2 \mathrm{~b}}=13.5\right.$ $\mathrm{Hz}, 1 \mathrm{H}, \mathrm{H}-2 \mathrm{a} \alpha), 2.23\left(\mathrm{ddd}, J_{1,2 \mathrm{~b}}=4.5, J_{2 \mathrm{~b}, 3}=6.6, J_{2 \mathrm{a}, 2 \mathrm{~b}}=14.2 \mathrm{~Hz}, 1 \mathrm{H}, \mathrm{H}-2 \mathrm{~b} \beta\right)$, $2.13\left(\mathrm{td}, J_{1,2 \mathrm{a}}=J_{2 \mathrm{a}, 3}=5.2, J_{2 \mathrm{a}, 2 \mathrm{~b}}=13.5 \mathrm{~Hz}, 1 \mathrm{H}, \mathrm{H}-2 \mathrm{~b} \alpha\right), 2.00\left(\mathrm{dd}, J_{2 \mathrm{a}, 3}=4.1, J_{2 \mathrm{a}, 2 \mathrm{~b}}\right.$ $=14.2 \mathrm{~Hz}, 1 \mathrm{H}, \mathrm{H}-2 \mathrm{a} \beta) ;{ }^{13} \mathrm{C} \mathrm{NMR}\left(125 \mathrm{MHz}, \mathrm{CDCl}_{3}\right) \delta 105.8(\mathrm{C} 1-\beta), 105.4(\mathrm{C} 1-$ $\alpha), 86.2$ (C4- $\beta$ ), 86.0 (C4- $\alpha$ ), 75.8 (C3- $\beta$ ), 75.6 (C3- $\alpha$ ), 55.3 (OMe- $\beta$ ), 55.1 (OMe$\alpha), 41.9$ (C2- $\beta$ ), 40.9 (C2- $\alpha$ ), 7.9 (C5- $\beta$ ), 6.7 (C5- $\alpha$ ); HRMS(ESI) $m / z$ calcd. for $\left[\mathrm{C}_{6} \mathrm{H}_{11} \mathrm{O}_{3} \mathrm{I}+\mathrm{Na}\right]^{+}:$280.9645, obsd.: 280.9655 .<smiles>CO[C@H]1OC(CI)[C@@H](O)[C@H](O)[C@H]1O</smiles>

Methyl 6-deoxy-6-iodo- $\alpha-D-g a l a c t o p y r a n o s e \quad(23)$. To a mixture of 1,2:3,4-O-di-isopropyl- $\alpha$-D-galactopyanose (2.6 g, $10 \mathrm{mmol}$ ), $\mathrm{PPh}_{3}$ $(3.93 \mathrm{~g}, 15 \mathrm{mmol})$ and imidazole $(1.36 \mathrm{~g}, 20 \mathrm{mmol})$ in dry THF $(100 \mathrm{~mL})$, was added iodine $(3.81 \mathrm{~g}, 15 \mathrm{mmol})$ in small portions. After refluxing for $1 \mathrm{~h}$, the reaction mixture was cooled to $\mathrm{rt}$, and quenched by the addition of $10 \%$ aq. $\mathrm{Na}_{2} \mathrm{~S}_{2} \mathrm{O}_{4}$. The product was extracted with EtOAc, and the combined organic layers were washed with brine, dried $\left(\mathrm{MgSO}_{4}\right)$, filtered and concentrated. Distillation of the residue gave 6-deoxy-6-iodo-1,2:3,4-O-di-isopropyl- $\alpha$-Dgalactopyranose as a yellow oil $(3.14 \mathrm{~g}, 8.48 \mathrm{mmol}, 85 \%)$. AcCl $(1.8 \mathrm{~mL})$ was added drop wise to a mixture of 6-deoxy-6-iodo-1,2:3,4-O-di-isopropyl- $\alpha$-D- 
galactopyranose $(3.14 \mathrm{~g}, 8.48 \mathrm{mmol})$ in $\mathrm{MeOH}(60 \mathrm{~mL})$. After stirring for 2 days, the mixture was concentrated in vacuo and the residue crystallised from $\mathrm{MeOH}$, to give the title compound (2.37 g, $7.80 \mathrm{mmol}, 92 \%)$ as white crystals. Mp 175.0$175.6{ }^{\circ} \mathrm{C} ; \mathrm{R}_{f}=0.43(\mathrm{MeOH} /$ EtOAc, 1/9, v/v); IR (film) 3354, 3227, 3007, 2953, 2935, 2906, 2836, 1454, 1417, 1360, 1347, 1297, 1257, 1200, 1145, 1132, 1102, 1078, 1026, 999, 935, 886, 854, 790, 721, 691, $657 \mathrm{~cm}^{-1}$; ${ }^{1} \mathrm{H}$ NMR (500 MHz, $\left.\mathrm{D}_{2} \mathrm{O}\right) \delta 4.69\left(\mathrm{~d}, J_{1,2}=3.6 \mathrm{~Hz}, 1 \mathrm{H}, \mathrm{H}-1\right), 3.97\left(\mathrm{dd}, J_{3,4}=3.3, J_{4,5}=1.2 \mathrm{~Hz}, 1 \mathrm{H}, \mathrm{H}-\right.$ 4), $3.90\left(\mathrm{ddd}, J_{4,5}=1.2 \mathrm{~Hz}, J_{5,6 \mathrm{a}}=5.3, J_{5,6 \mathrm{~b}}=8.0 \mathrm{~Hz} 1 \mathrm{H}, \mathrm{H}-5\right), 3.75\left(\mathrm{dd}, J_{1,2}=3.6\right.$, $\left.J_{2,3}=10.2 \mathrm{~Hz}, 1 \mathrm{H}, \mathrm{H}-2\right), 3.69\left(\mathrm{dd}, J_{2,3}=10.2, J_{3,4}=3.3 \mathrm{~Hz}, 1 \mathrm{H}, \mathrm{H}-3\right), 3.46(\mathrm{~s}, 3 \mathrm{H}$, $\mathrm{OMe}), 3.37\left(\mathrm{dd}, J_{5,6 \mathrm{a}}=5.3, J_{6 \mathrm{a}, 6 \mathrm{~b}}=10.2 \mathrm{~Hz}, 1 \mathrm{H}, \mathrm{H}-6 \mathrm{a}\right), 3.33\left(\mathrm{dd}, J_{5,6 \mathrm{~b}}=8.0, J_{6 \mathrm{a}, 6 \mathrm{~b}}\right.$ $=10.2 \mathrm{~Hz}, 1 \mathrm{H}, \mathrm{H}-6 \mathrm{~b}) ;{ }^{13} \mathrm{C}$ NMR (125 MHz, $\left.\mathrm{D}_{2} \mathrm{O}\right) \delta 100.2$ (C1), 71.4 (C5), 70.4 (C4), 69.9 (C2), 68.4 (C3), 54.6 (OMe), 2.3 (C6). HRMS(ESI) m/z calcd. for $\left[\mathrm{C}_{7} \mathrm{H}_{13} \mathrm{IO}_{5}+\mathrm{Na}\right]^{+}:$326.9700, obsd.: 326.9709 .<smiles>CO[C@H]1OC(CI)[C@@H](O)[C@H](O)[C@H]1O</smiles>

Methyl 6-deoxy-6-iodo- $\alpha$-D-glucopyranose (33). By subjecting methyl D-glucose $32(6.0 \mathrm{~g}, 30.9 \mathrm{mmol})$ to the general procedure for the synthesis of methyl iodo-glycosides, and then crystallising from ethanol, glucoside 33 was obtained as white crystals $(9.2 \mathrm{~g}, 30.3 \mathrm{mmol}$, 98\%). Mp 147.2-148.2 ${ }^{\circ} \mathrm{C} ; \mathrm{R}_{f}=0.5(\mathrm{EtOAc} / \mathrm{MeOH}, 85 / 15, \mathrm{v} / \mathrm{v}) ; \mathrm{IR}$ (film) $3337,2916,2840,1626,1455,1410,1371,1313,1195,1011,932,883,748, \mathrm{~cm}^{-}$ 1. ${ }^{1} \mathrm{H}$ NMR (500 MHz, D $\left.2 \mathrm{O}\right) \delta 4.67\left(\mathrm{~d}, J_{1,2}=3.9 \mathrm{~Hz}, 1 \mathrm{H}, \mathrm{H}-1\right), 3.57$ (dd, $J_{3,4}=$ 9.1, $\left.J_{2,3} 9.8 \mathrm{~Hz}, 1 \mathrm{H}, \mathrm{H}-3\right), 3.51\left(\mathrm{dd}, J_{5,6}=2.1, J_{6 \mathrm{a}, 6 \mathrm{~b}}=10.7 \mathrm{~Hz}, 1 \mathrm{H}, \mathrm{H}-6 \mathrm{a}\right), 3.46$ $\left(\mathrm{dd}, J_{1,2}=3.9, J_{2,3}=9.8 \mathrm{~Hz}, 1 \mathrm{H}, \mathrm{H}-2\right), 3.34(\mathrm{~s}, 3 \mathrm{H}, \mathrm{OMe}), 3.32\left(\mathrm{ddd}, J_{5,6 \mathrm{a}}=2.1\right.$, $\left.J_{5,6 \mathrm{~b}}=6.4, J_{4,5}=9.1 \mathrm{~Hz}, 1 \mathrm{H}, \mathrm{H}-5\right), 3.28\left(\mathrm{dd}, J_{5,6 \mathrm{~b}}=6.4, J_{6 \mathrm{a}, 6 \mathrm{~b}}=10.7 \mathrm{~Hz}, 1 \mathrm{H}, \mathrm{H}-\right.$ 6b), $3.20\left(\mathrm{t}, J_{3,4}=J_{4,5}=9.1 \mathrm{~Hz}, 1 \mathrm{H}, \mathrm{H}-4\right) ;{ }^{13} \mathrm{C} \mathrm{NMR}\left(125 \mathrm{MHz}, \mathrm{D}_{2} \mathrm{O}\right) \delta 99.3$ (C1), 73.4 (C4), 72.4 (C3), 71.2 (C2), 70.1 (C5), 55.3 (OMe), 6.6 (C6); HRMS(ESI) $m / z$ calcd. for $\left[\mathrm{C}_{7} \mathrm{H}_{13} \mathrm{IO}_{5}+\mathrm{Na}\right]^{+}: 326.9700$, obsd.: 326.9706 . 


\section{Methyl 2,6-dideoxy-6-iodo-3,4- $O$-isopropylidene- $\alpha / \beta$-D-}

galactopyranoside (44). To a solution of 2-deoxy-D-galatose (200 mg, 0.61 $\mathrm{mmol})$ in $\mathrm{MeOH} /$ Acetone/dimethoxypropane $(2 / 2 / 2 \mathrm{~mL}) \mathrm{AcCl}(180 \mu \mathrm{L})$ was added and the solution stirred $18 \mathrm{~h}$ at room temperature. The reaction was quenched with basic dowex, filtered and concentrated. The resulting oil was used without purification. $\mathrm{R}_{f}=0.13$ (Ethyl Acetate/Petroleum Ether, $1 / 1, \mathrm{v} / \mathrm{v}$ ); ${ }^{1} \mathrm{H}$ NMR $\left(500 \mathrm{MHz}, \mathrm{CDCl}_{3}\right) \delta 4.86\left(\mathrm{dd}, J_{1,2 \mathrm{a}}=5.1, J_{1,2 \mathrm{~b}}=6.0 \mathrm{~Hz}, 1 \mathrm{H}, \mathrm{H}-1\right), 4.47\left(\mathrm{ddd}, J_{2 \mathrm{~b}, 3}\right.$ $\left.=4.1, J_{2 \mathrm{a}, 3}=5.1, J_{3,4}=6.9 \mathrm{~Hz}, 1 \mathrm{H}, \mathrm{H}-3\right), 4.16\left(\mathrm{dd}, J_{4,5}=1.7, J_{3,4}=6.9 \mathrm{~Hz}, 1 \mathrm{H}, \mathrm{H}-\right.$ 4), $3.89\left(\mathrm{dd}, J_{5,6 \mathrm{a}}=5.6, J_{6 \mathrm{a}, 6 \mathrm{~b}}=10.6 \mathrm{~Hz}, 1 \mathrm{H}, \mathrm{H}-6 \mathrm{a}\right), 3.80\left(\mathrm{ddd}, J_{4,5}=1.7, J_{5,6 \mathrm{~b}}=\right.$ $\left.4.3, J_{5,6 \mathrm{a}}=5.6 \mathrm{~Hz}, 1 \mathrm{H}, \mathrm{H}-5\right), 3.77\left(\mathrm{dd}, J_{5,6 \mathrm{~b}}=4.3, J_{6 \mathrm{a}, 6 \mathrm{~b}}=10.6 \mathrm{~Hz}, 1 \mathrm{H}, \mathrm{H}-6 \mathrm{~b}\right), 3.37$ (s, 3H, OMe), $2.17\left(\mathrm{dt}, J_{2 \mathrm{a}, 2 \mathrm{~b}}=14.8, J_{1,2 \mathrm{a}}=J_{2 \mathrm{a}, 3}=5.1 \mathrm{~Hz}, 1 \mathrm{H}, \mathrm{H}-2 \mathrm{a}\right), 1.73$ (ddd, $\left.J_{2 \mathrm{~b}, 3}=4.1, J_{1,2 \mathrm{~b}}=6.0, J_{2 \mathrm{a}, 2 \mathrm{~b}}=14.8 \mathrm{~Hz}, 1 \mathrm{H}, \mathrm{H}-2 \mathrm{~b}\right), 1.47(\mathrm{~s}, \mathrm{iPr}), 1.31(\mathrm{~s}, \mathrm{PPr}) ;{ }^{13} \mathrm{C}$ NMR (75 MHz, $\left.\mathrm{CDCl}_{3}\right) 109.2\left(\mathrm{iPr}-\underline{\mathrm{C}}\left(\mathrm{CH}_{3}\right)_{2}\right) 97.4(\mathrm{C} 1), 73.4(\mathrm{C} 4), 70.5$ (C3), 68.5 (C5), 62.8 (C6), 55.0 (OMe), 30.8 (C2), 26.8, 25.3 (iPr-C $\left.\left(\mathrm{CH}_{3}\right)_{2}\right)$; HRMS(ESI) $m / z$ calcd. for $\left[\mathrm{C}_{10} \mathrm{H}_{18} \mathrm{O}_{5}+\mathrm{Na}\right]^{+}: 241.1046$, obsd.: 241.1046. To a solution of 43 (0.61 mmol) in THF $(7 \mathrm{~mL})$ was added $\mathrm{PPh}_{3}(456 \mathrm{mg}, 1.74 \mathrm{mmol})$, imidazole (180 mg, $2.62 \mathrm{mmol})$ and $\mathrm{I}_{2}(442 \mathrm{mg}, 174 \mathrm{mmol})$. The mixture was stirred at reflux for $18 \mathrm{~h}$, then cooled and concentrated. The syrup was redissolved in Ethyl Acetate $(20 \mathrm{~mL})$ and washed sat. aq. $\mathrm{Na}_{2} \mathrm{~S}_{2} \mathrm{O}_{3}(2 \times 15 \mathrm{~mL})$ Brine $(20 \mathrm{~mL})$, dried $\mathrm{MgSO}_{4}$, filtered and concentrated. The resulting oil was purified by flash column chromatography (Petroleum Ether/EtOAc, 15/1, v/v) then crystallised from hexanes to give 44 as white crystals (142 $\mathrm{mg}, 0.434 \mathrm{mmol}, 72 \%$ from 2-dexoy-Dgalactose), $\mathrm{R}_{f}=0.77$ (Petroleum Ether/EtOAc, 1/1, v/v); Mp 91-92 ${ }^{\circ} \mathrm{C} ;[\alpha]_{\mathrm{D}}{ }^{21}=$ +72.4 ( $\left.c=1.0, \mathrm{CHCl}_{3}\right)$; IR (film) 2982, 2936, 2912, 2833, 1439, 1373, 1246, 1214, 1186, 1088, 1047, 969, 880, $738 \mathrm{~cm}^{-1}$. ${ }^{1} \mathrm{H}$ NMR (500 MHz, $\left.\mathrm{CDCl}_{3}\right) \delta 4.86$ $\left(\mathrm{dd}, J_{1,2 \mathrm{a}}=5.4, J_{1,2 \mathrm{~b}}=6.6 \mathrm{~Hz}, 1 \mathrm{H}, \mathrm{H}-1\right), 4.49\left(\mathrm{ddd}, J_{2 \mathrm{~b}, 3}=3.7, J_{2 \mathrm{a}, 3}=4.6, J_{3,4}=7.3\right.$ $\mathrm{Hz}, 1 \mathrm{H}, \mathrm{H}-3), 4.26\left(\mathrm{dd}, J_{4,5}=2.0, J_{3,4}=7.3 \mathrm{~Hz}, 1 \mathrm{H}, \mathrm{H}-4\right), 3.86\left(\mathrm{ddd}, J_{5,4}=2.0\right.$, $\left.J_{5,6 \mathrm{a}}=5.8, J_{5,6 \mathrm{~b}}=8.1 \mathrm{~Hz}, 1 \mathrm{H}, \mathrm{H}-5\right), 3.47(\mathrm{~s}, 3 \mathrm{H}, \mathrm{OMe}), 3.34\left(\mathrm{dd}, J_{5,6 \mathrm{a}}=5.8, J_{6 \mathrm{a}, 6 \mathrm{~b}}\right.$ $=10.2 \mathrm{~Hz}, 1 \mathrm{H}, \mathrm{H}-6 \mathrm{a}), 3.28\left(\mathrm{dd}, J_{5,6 \mathrm{~b}}=8.1, J_{6 \mathrm{a}, 6 \mathrm{~b}}=10.2 \mathrm{~Hz}, 1 \mathrm{H}, \mathrm{H}-6 \mathrm{~b}\right), 2.24$ (ddd, $\left.J_{2 \mathrm{a}, 3}=4.6, J_{1,2 \mathrm{a}}=5.4, J_{2 \mathrm{a}, 2 \mathrm{~b}}=15.1 \mathrm{~Hz}, 1 \mathrm{H}, \mathrm{H}-2 \mathrm{a}\right), 1.64\left(\mathrm{ddd}, J_{2 \mathrm{~b}, 3}=3.7, J_{1,2 \mathrm{~b}}=6.6\right.$, 
$\left.J_{2 \mathrm{a}, 2 \mathrm{~b}}=15.1 \mathrm{~Hz}, 1 \mathrm{H}, \mathrm{H}-2 \mathrm{~b}\right), 1.48(\mathrm{~s}, 3 \mathrm{H}, \mathrm{iPr}), 1.34$ (s, 3H, iPr); ${ }^{13} \mathrm{C}$ NMR $(75$ $\left.\mathrm{MHz}, \mathrm{CDCl}_{3}\right) 109.3\left(\mathrm{iPr}-\underline{\mathrm{C}}\left(\mathrm{CH}_{3}\right)_{2}\right) 97.6$ (C1), 73.4 (C4), 70.9 (C3), 70.0 (C5), $55.2(\mathrm{OMe}), 30.2$ (C2), 26.6, $25.2\left(\mathrm{iPr}-\mathrm{C}\left(\underline{\mathrm{CH}}_{3}\right)_{2}\right)$, 3.2 (C6); HRMS(ESI) $\mathrm{m} / z$ calcd. for $\left[\mathrm{C}_{10} \mathrm{H}_{17} \mathrm{O}_{4} \mathrm{I}+\mathrm{Na}\right]^{+}: 351.0064$, obsd.: 351.0072 .<smiles>CO[C@@H]1C[C@H](O)[C@H](O)[C@@H](CI)O1</smiles>

Methyl 2,6-dideoxy-6-iodo- $/$ / $\beta$-D-galactopyranoside (45). To a solution of iodo-galactoside $44(237 \mathrm{mg}, 0.79 \mathrm{mmol})$ in $\mathrm{MeOH}(10 \mathrm{ml})$, at $0{ }^{\circ} \mathrm{C}$ $\mathrm{AcCl}(200 \mu \mathrm{l})$ was added. The reaction was stirred at room temperature for 5 days, quenched with Dowex $\left(\mathrm{OH}^{-}\right)$and then concentrated in vacuo. The product was purified via gradient flash column chromatography (Petroleum Ether/EtOAc, $3 / 1$ to $1 / 1, \mathrm{v} / \mathrm{v}$ ) to provide galactoside 45 as a colourless oil $(200 \mathrm{mg}, 0.69 \mathrm{mmol}$, 94\%). $\mathrm{R}_{f}=0.11(\mathrm{EtOAc}) ;[\alpha]_{\mathrm{D}}^{21}=+0.11(c=1.0, \mathrm{MeOH}) ; \mathrm{IR}$ (film) 3292, 2925, 2854, 1735, 1457, 1209, 1130, 1034, $668 \mathrm{~cm}^{-1} ;{ }^{1} \mathrm{H}$ NMR $\left(500 \mathrm{MHz}, \mathrm{CD}_{3} \mathrm{OD}\right) \delta$ $4.71\left(\mathrm{~d}, J_{1,2 \mathrm{a}}=3.6 \mathrm{~Hz}, 1 \mathrm{H}, \mathrm{H}-1\right), 3.81\left(\mathrm{ddd}, J_{3,4}=3.2, J_{2 \mathrm{~b}, 3}=4.1, J_{2 \mathrm{~b}, 3}=12.6 \mathrm{~Hz}\right.$, $1 \mathrm{H}, \mathrm{H}-3), 3.78-3.72(\mathrm{~m}, 2 \mathrm{H}, \mathrm{H}-4$ and $\mathrm{H}-5), 3.31\left(\mathrm{~s}, 1 \mathrm{H}, \mathrm{OCH}_{3}\right), 3.30-3.22(\mathrm{~m}, 2 \mathrm{H}$, H-6a and H-6b), $1.82\left(\mathrm{td}, J_{2 \mathrm{a}, 2 \mathrm{~b}}=J_{2 \mathrm{a}, 3}=12.6, J_{1,2 \mathrm{a}}=3.6, \mathrm{~Hz}, 1 \mathrm{H}, \mathrm{H}-2 \mathrm{a}\right), 1.62(\mathrm{dd}$, $\left.J_{2 \mathrm{~b}, 3}=5.1, J_{2 \mathrm{a}, 2 \mathrm{~b}}=12.6 \mathrm{~Hz}, 1 \mathrm{H}, \mathrm{H}-2 \mathrm{~b}\right) ;{ }^{13} \mathrm{C} \mathrm{NMR}\left(125 \mathrm{MHz}, \mathrm{CD}_{3} \mathrm{OD}\right) \delta 100.3$ (C1), 72.9 (C4), 70.5 (C5), 66.7 (C3), $55.5\left(\mathrm{OCH}_{3}\right), 33.1$ (C2), 4.5 (C6); HRMS(ESI) $\mathrm{m} / \mathrm{z}$ calcd. for $\left[\mathrm{C}_{7} \mathrm{H}_{13} \mathrm{O}_{4} \mathrm{I}+\mathrm{Na}\right]^{+}: 310.9751$, obsd.: 310.9756 .

\section{General procedure for the synthesis of alkenylamines.}

To a solution of methyl iodo-glycoside $(274 \mathrm{mg}, 1 \mathrm{mmol})$ in a saturated solution of $\mathrm{NH}_{4} \mathrm{OAc}$ in $\mathrm{EtOH}(20 \mathrm{~mL})$ was added activated $\mathrm{Zn}(327 \mathrm{mg}, 5 \mathrm{mmol})$, $\mathrm{NaCNBH}_{3}(3 \mathrm{mmol})$ and $30 \%$ aqueous $\mathrm{NH}_{3}(8 \mathrm{~mL})$. The mixture was stirred at reflux for $18 \mathrm{~h}$, cooled to room temperature, filtered to remove excess zinc, and concentrated under reduced pressure. The residue was redissolved in $\mathrm{H}_{2} \mathrm{O}$, loaded on to a Dowex $\mathrm{H}^{+}$ion exchange resin, and washed several times with $\mathrm{H}_{2} \mathrm{O}$ to remove excess salt. The amine product was then eluted with 15 to $30 \%$ aqueous $\mathrm{NH}_{3}$. The eluent was concentrated under reduced pressure then converted to the $\mathrm{HCl}$ salt using $1 \mathrm{M} \mathrm{HCl}$. If necessary, further purification could be achieved using 
gradient flash chromatography (DCM/EtOH/MeOH/30\% aqueous $\mathrm{NH}_{3}, 25 / 2 / 2 / 1$ to $5 / 2 / 2 / 1, \mathrm{v} / \mathrm{v} / \mathrm{v} / \mathrm{v})$.<smiles>C=CC(O)C(O)C(O)CN</smiles>

(2S,3S,4S)-1-Amino-hex-5-ene-2,3,4-triol (27). Вy subjecting triol $23(520 \mathrm{mg}, 1.71 \mathrm{mmol})$ to the general procedure for the synthesis of alkenylamines, alkenylamine 27 was obtained as the $\mathrm{HCl}$ salt $(215 \mathrm{mg}, 1.46$ mmol, 86\%). $\mathrm{R}_{f}=0.14\left(\mathrm{DCM} / \mathrm{EtOH} / \mathrm{MeOH} / 30 \%\right.$ aqueous $\left.\mathrm{NH}_{3}, 5 / 2 / 2 / 1, \mathrm{v} / \mathrm{v} / \mathrm{v} / \mathrm{v}\right)$; $[\alpha]_{\mathrm{D}}{ }^{20}=-20.3(c=1.0, \mathrm{EtOH})$; IR (film) 3304, 2922, 1624, 1507, 1424, 1298, 1032, 998, 932, $836 \mathrm{~cm}^{-1} ;{ }^{1} \mathrm{H}$ NMR (500 MHz, $\left.\mathrm{D}_{2} \mathrm{O}\right) \delta 5.93$ (ddd, $J_{4,5}=7.0, J_{5,6-c i s}$ $\left.=10.5, J_{5,6 \text {-trans }}=17.4 \mathrm{~Hz}, 1 \mathrm{H}, \mathrm{H}-5\right), 5.35\left(\mathrm{dt}, J_{5,6-\text { trans }}=17.4, J_{4,6-\text { trans }}=J_{6-\text {-is,6-trans }}\right.$ $=1.2 \mathrm{~Hz}, 1 \mathrm{H}, \mathrm{H}-6$-trans), $5.29\left(\mathrm{dt}, J_{5,6-c i s}=10.5, J_{4,6-c i s}=J_{6-c i s, 6-\text { trans }}=1.2 \mathrm{~Hz} 1 \mathrm{H}\right.$, H-6-cis), $4.12\left(\mathrm{dd}, J_{3,4}=8.0, J_{4,5}=7.1 \mathrm{~Hz}, 1 \mathrm{H}, \mathrm{H}-4\right), 4.10\left(\mathrm{ddd}, J_{2,3}=2.4, J_{1 \mathrm{a}, 2}=\right.$ $\left.7.5, J_{1 \mathrm{~b}, 2}=7.5 \mathrm{~Hz}, 1 \mathrm{H}, \mathrm{H}-2\right), 3.44\left(\mathrm{dd}, J_{2,3}=2.4, J_{3,4}=8.0 \mathrm{~Hz}, 1 \mathrm{H}, \mathrm{H}-3\right), 3.13(\mathrm{~m}$, 2H, H-1a and H-1b); ${ }^{13} \mathrm{C}$ NMR (125 MHz, D $\left.2 \mathrm{O}\right) \delta 136.8$ (C5), 118.3 (C6), 73.7 (C3), $72.0 \quad$ (C4), 66.3 (C2), 42.4 (C1). $\quad$ HRMS(ESI) $\mathrm{m} / z$ calcd. for $\left[\mathrm{C}_{6} \mathrm{H}_{13} \mathrm{NO}_{3}+\mathrm{H}\right]^{+}: 148.0968$, obsd.:148.0973.<smiles>C=CC(O)C(O)CCN</smiles>

(3S,4R)-1-Amino-hex-5-ene-3,4-diol (46). By subjecting methyl iodoglycoside 45 to the general procedure for the synthesis of alkenylamines, alkenylamine 46 was obtained as the $\mathrm{HCl}$ salt $(35 \mathrm{mg}, 0.211$ mmol, 99\%). $\mathrm{R}_{f}=0.11\left(\mathrm{DCM} / \mathrm{EtOH} / \mathrm{MeOH} / 30 \%\right.$ aqueous $\left.\mathrm{NH}_{3}, 5 / 2 / 2 / 1, \mathrm{v} / \mathrm{v} / \mathrm{v} / \mathrm{v}\right)$; $[\alpha]_{\mathrm{D}}^{25}=-114(c=0.1, \mathrm{EtOH})$; IR (film) 3370, 3321, 2962, 2836, 1642, 1504, $1435,1378,1025,652 \mathrm{~cm}^{-1} .{ }^{1} \mathrm{H}$ NMR $\left(500 \mathrm{MHz}, \mathrm{D}_{2} \mathrm{O}\right) \delta 5.74\left(\mathrm{ddd}, J_{4,5}=6.2\right.$, $\left.J_{5,6 \text {-cis }}=10.3, J_{5,6 \text {-trans }}=17.1 \mathrm{~Hz}, 1 \mathrm{H}, \mathrm{H}-5\right), 5.17$ (d, $J_{5,6 \text {-trans }}=17.1 \mathrm{~Hz}, 1 \mathrm{H}, \mathrm{H}-6$ cis), $5.14\left(\mathrm{~d}, J_{5,6-c i s}=10.3 \mathrm{~Hz}, 1 \mathrm{H}, \mathrm{H}-6\right.$-trans $), 3.90\left(\mathrm{dd}, J_{3,4}=4.6, J_{4,5}=6.2 \mathrm{~Hz}\right.$, $1 \mathrm{H}, \mathrm{H}-4), 3.56\left(\mathrm{ddd}, J_{2 \mathrm{a}, 3}=3.2, J_{3,4}=4.6, J_{2 \mathrm{~b}, 3}=9.6 \mathrm{~Hz}, 1 \mathrm{H}, \mathrm{H}-3\right), 2.71\left(\mathrm{dd}, J_{1 \mathrm{a}, 2 \mathrm{~b}}\right.$ $\left.=5.9, J_{1 \mathrm{a}, 2 \mathrm{a}}=8.5, J_{1 \mathrm{a}, 1 \mathrm{~b}}=12.8 \mathrm{~Hz}, 1 \mathrm{H}, \mathrm{H}-1 \mathrm{a}\right), 2.64\left(\mathrm{ddd}, J_{1 \mathrm{~b}, 2 \mathrm{a}}=7.0, J_{1 \mathrm{~b}, 2 \mathrm{~b}}=8.0\right.$, $\left.J_{1 \mathrm{a}, 1 \mathrm{~b}}=12.8 \mathrm{~Hz}, 1 \mathrm{H}, \mathrm{H}-1 \mathrm{~b}\right), 1.59$ (dddd, $J_{2 \mathrm{a}, 3}=3.2, J_{1 \mathrm{~b}, 2 \mathrm{a}}=7.0, J_{1 \mathrm{a}, 2 \mathrm{a}}=8.5, J_{2 \mathrm{a}, 2 \mathrm{~b}}=$ $17.5 \mathrm{~Hz}, 1 \mathrm{H}, \mathrm{H}-2 \mathrm{a}), 1.42\left(\mathrm{dddd}, J_{1 \mathrm{a}, 2 \mathrm{~b}}=5.9, J_{1 \mathrm{~b}, 2 \mathrm{~b}}=8.0, J_{2 \mathrm{~b}, 3}=9.6, J_{2 \mathrm{a}, 2 \mathrm{~b}}=17.5\right.$ $\mathrm{Hz}, 1 \mathrm{H}, \mathrm{H}-2 \mathrm{~b}) ;{ }^{13} \mathrm{C}$ NMR (75 MHz, $\left.\mathrm{D}_{2} \mathrm{O}\right) \delta 135.5$ (C5), 118.0 (C6), 75.4 (C4), 
71.6 (C3), 37.1 (C1), 28.9 (C2); HRMS(ESI) $m / z$ calcd. for $\left[\mathrm{C}_{6} \mathrm{H}_{14} \mathrm{O}_{2} \mathrm{~N}+\mathrm{H}\right]^{+}$: 132.1019, obsd.: 132.1022 .

\section{General Procedure for the iodo-cyclisation/carbamate formation.}

To a solution of the alkenylamine hydrochloride $(154 \mathrm{mg}, 1 \mathrm{mmol})$ in water (5 $\mathrm{mL})$ was added $\mathrm{NaHCO}_{3}(126 \mathrm{mg}, 1.5 \mathrm{mmol})$ and $\mathrm{I}_{2}(279 \mathrm{mg}, 1.1 \mathrm{mmol})$. The solution was stirred $18 \mathrm{~h}$ at room temperature, filtered and concentrated under reduced pressure. The product was purified by silica gel chromatography (1-5\% $\mathrm{MeOH}$ in EtOAc, v/v).

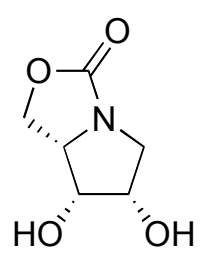

$(6 S, 7 R, 7 \mathrm{a} S)-6,7-D i h y d r o x y-t e t r a h y d r o-p y r r o l o[1,2-c]$ oxazol3(1H)-one (24). By subjecting alkenylamine 23 (30 $\mathrm{mg}, 0.20 \mathrm{mmol})$ to the general procedure for the iodo-cyclisation/carbamate formation, carbamate $\mathbf{2 4}$ was isolated as an amorphous white powder (29 $\mathrm{mg}, 0.18 \mathrm{mmol}$, 93\%). Characterisation data was in accordance with literature values. ${ }^{34}[\alpha]_{\mathrm{D}}{ }^{19}=+32.2(c$ $=0.3, \mathrm{EtOH})$; IR (film) 3332, 2977, 1717, 1474, 1411, 1250, 1130, $1068 \mathrm{~cm}^{-1} .{ }^{1} \mathrm{H}$ NMR (500 MHz, D $2 \mathrm{O}) \delta 4.52$ (m, 3H, H-2, H-5a and H-5b), 4.14 (ddd, $J_{3,4}=3.1$, $\left.J_{4,5 \mathrm{a}}=5.0, J_{4,5 \mathrm{~b}}=7.9 \mathrm{~Hz}, 1 \mathrm{H}, \mathrm{H}-4\right), 4.01\left(\mathrm{dd}, J_{3,4}=3.1, J_{2,3}=3.3 \mathrm{~Hz}, 1 \mathrm{H}, \mathrm{H}-3\right)$, $3.51\left(\mathrm{dd}, J_{1 \mathrm{a}, 2}=8.1, J_{1 \mathrm{a}, 1 \mathrm{~b}}=10.8 \mathrm{~Hz}, 1 \mathrm{H}, \mathrm{H}-1 \mathrm{a}\right), 3.15\left(\mathrm{dd}, J_{1 \mathrm{~b}, 2}=7.9, J_{1 \mathrm{a}, 1 \mathrm{~b}}=10.8\right.$

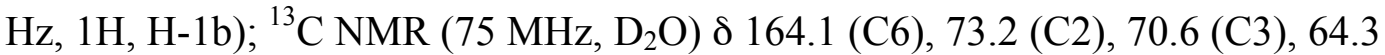
(C5), 61.5 (C4), 48.6 (C1); HRMS(ESI) $m / z$ calcd. for $\left[\mathrm{C}_{6} \mathrm{H}_{9} \mathrm{O}_{4} \mathrm{~N}+\mathrm{Na}\right]^{+}$: 182.0424, obsd.: 182.0429 .

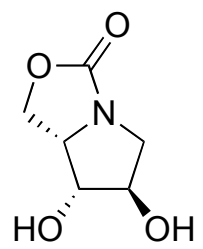

(6R,7R,7aS)-6,7-Dihydroxy-tetrahydro-pyrrolo[1,2-c]oxazol-3 (1H)-one (16). By subjecting alkenylamine 15 (40 $\mathrm{mg}, 0.26 \mathrm{mmol})$ to the general procedure for the iodo-cyclisation/carbamate formation, carbamate 16 was isolated as an amorphous white powder $(38.5 \mathrm{mg}, 0.24 \mathrm{mmol}, 93 \%) .[\alpha]_{\mathrm{D}}{ }^{18}=$ +20.1 $(c=0.6$, EtOH); IR (film) 3372, 2954, 2845, 1715, 1635, 1416, 1253, 1079, $955 \mathrm{~cm}^{-1} ;{ }^{1} \mathrm{H}$ NMR $\left(500 \mathrm{MHz}, \mathrm{D}_{2} \mathrm{O}\right) \delta 4.51\left(\mathrm{t}, J_{4,5 \mathrm{a}}=J_{5 \mathrm{a}, 5 \mathrm{~b}}=9.2 \mathrm{~Hz}, 1 \mathrm{H}, \mathrm{H}-5 \mathrm{a}\right)$ 
$4.38\left(\mathrm{dd}, J_{4,5 \mathrm{~b}}=2.9, J_{5 \mathrm{a}, 5 \mathrm{~b}}=9.2 \mathrm{~Hz}, 1 \mathrm{H}, \mathrm{H}-5 \mathrm{~b}\right), 4.27\left(\mathrm{~d}, J_{1 \mathrm{a}, 2}=5.1 \mathrm{~Hz}, 1 \mathrm{H}, \mathrm{H}-2\right)$, $4.17\left(\mathrm{dt}, J_{4,5 \mathrm{a}}=9.2, J_{4,5 \mathrm{~b}}=J_{3,4}=2.9 \mathrm{~Hz}, 1 \mathrm{H}, \mathrm{H}-4\right), 3.90\left(\mathrm{~d}, J_{3,4}=2.9 \mathrm{~Hz}, 1 \mathrm{H}, \mathrm{H}-3\right)$, $3.67\left(\mathrm{dd}, J_{1 \mathrm{a}, 2}=5.1, J_{1 \mathrm{a}, 1 \mathrm{~b}}=12.5 \mathrm{~Hz}, 1 \mathrm{H}, \mathrm{H}-1 \mathrm{a}\right), 3.01\left(\mathrm{~d}, J_{1 \mathrm{a}, 1 \mathrm{~b}}=12.5 \mathrm{~Hz}, 1 \mathrm{H}, \mathrm{H}-\right.$ 1b); ${ }^{13} \mathrm{C}$ NMR (125 MHz, $\left.\mathrm{D}_{2} \mathrm{O}\right) \delta 164.4$ (C=O), 76.5 (C2), 74.3 (C3), 64.0 (C5), 62.0 (C4), 52.2 (C1); HRMS(ESI) $m / z$ calcd. for $\left[\mathrm{C}_{6} \mathrm{H}_{9} \mathrm{O}_{4} \mathrm{~N}+\mathrm{Na}\right]^{+}:$182.0429, obsd.: 182.0424 .

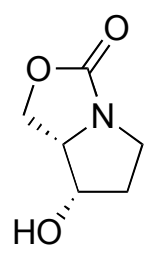

(7S,7aS)-7-Hydroxy-tetrahydro-pyrrolo[1,2-c]oxazol-3(1H)-one (21).

By subjecting alkenylamine $20(30 \mathrm{mg}, 0.21 \mathrm{mmol})$ to the general procedure for iodo-cyclisation, carbamate $\mathbf{2 1}$ was obtained as an amorphous white powder (27 $\mathrm{mg}, 0.19 \mathrm{mmol}, 90 \%)$. $[\alpha]_{\mathrm{D}}{ }^{17}=+7.0(c=0.1, \mathrm{EtOH})$; IR (film), 3419, 3385, 3047, 2986, 2931, 1730, 1448, $1087 \mathrm{~cm}^{-1} ;{ }^{1} \mathrm{H}$ NMR (500 MHz, D 2 O) $\delta 4.42\left(\mathrm{t}, J_{4,5 \mathrm{a}}=\right.$ $\left.J_{5 \mathrm{a}, 5 \mathrm{~b}}=9.2 \mathrm{~Hz}, 1 \mathrm{H}, \mathrm{H}-5 \mathrm{a}\right), 4.34\left(\mathrm{dd}, J_{4,5 \mathrm{~b}}=3.6, J_{5 \mathrm{a}, 5 \mathrm{~b}}=9.2 \mathrm{~Hz}, 1 \mathrm{H}, \mathrm{H}-5 \mathrm{~b}\right), 4.08(\mathrm{t}$, $\left.J_{3,4}=J_{2 \mathrm{a}, 3}=3.6 \mathrm{~Hz}, 1 \mathrm{H}, \mathrm{H}-3\right), 3.90\left(\mathrm{td}, J_{3,4}=J_{4,5 \mathrm{~b}}=3.6, J_{4,5 \mathrm{a}}=9.2 \mathrm{~Hz}, 1 \mathrm{H}, \mathrm{H}-4\right)$, $3.37\left(\mathrm{ddd}, J_{1 \mathrm{a}, 2 \mathrm{~b}}=8.1, J_{1 \mathrm{a}, 2 \mathrm{a}}=9.5, J_{1 \mathrm{a}, 1 \mathrm{~b}}=10.9 \mathrm{~Hz}, 1 \mathrm{H}, \mathrm{H}-1 \mathrm{a}\right), 3.15\left(\mathrm{ddd}, J_{1 \mathrm{~b}, 2 \mathrm{~b}}=\right.$ $\left.2.2, J_{1 \mathrm{~b}, 2 \mathrm{a}}=10.0, J_{1 \mathrm{a}, 1 \mathrm{~b}}=10.9 \mathrm{~Hz}, 1 \mathrm{H}, \mathrm{H}-1 \mathrm{~b}\right), 2.06\left(\mathrm{ddd}, J_{1 \mathrm{a}, 2 \mathrm{a}}=9.5, J_{1 \mathrm{~b}, 2 \mathrm{a}}=10.0\right.$, $\left.J_{2 \mathrm{a}, 2 \mathrm{~b}}=14.2 \mathrm{~Hz}, 1 \mathrm{H}, \mathrm{H}-2 \mathrm{a}\right), 1.93\left(\mathrm{ddd}, J_{1 \mathrm{~b}, 2 \mathrm{~b}}=2.2, J_{1 \mathrm{a}, 2 \mathrm{~b}}=8.1, J_{2 \mathrm{a}, 2 \mathrm{~b}}=14.2 \mathrm{~Hz}\right.$, 1H, H-2b); ${ }^{13} \mathrm{C}$ NMR (125 MHz, D $\left.2 \mathrm{O}\right) \delta 171.0(\mathrm{C}=\mathrm{O}), 69.6$ (C3), 64.4 (C4), 64.3 (C5), 43.0 (C1), 33.7 (C2). HRMS(ESI) $\mathrm{m} / z$ calcd. for $\left[\mathrm{C}_{6} \mathrm{H}_{9} \mathrm{NO}_{3}+\mathrm{Na}\right]^{+}: 166.0475$ obsd.:166.0480.<smiles>O=C1OC[C@H]2[C@@H](O)[C@H](O)[C@@H](O)CN12</smiles>

28a 28b<smiles>O=C1NC[C@H]2O[C@H](CO1)[C@@H](O)[C@H]2O</smiles>

31

(6S,7R,8S,8aR)-6,7,8-Trihydroxy-hexahydro-oxazolo[3,4-a]pyridin-3(5H)one (28a), (6S,7R,8S,8aS)-6,7,8-Trihydroxy-hexahydro-oxazolo[3,4-a]pyridin3(5H)-one (28b) and (1R,7S,8S,9R)-8,9-Dihydroxy-3,10-dioxa-5-azabicyclo[5.2.1]decan-4-one (31). A suspension of alkenylamine hydrochloride 27 
(79 mg, $0.50 \mathrm{mmol})$ and $\mathrm{I}_{2}(0.59 \mathrm{~g}, 2.3 \mathrm{mmol})$ in sat. aq. $\mathrm{NaHCO}_{3}(2 \mathrm{~mL})$ was stirred for $3 \mathrm{~d}$ at $40{ }^{\circ} \mathrm{C}$, filtered and concentrated under reduced pressure. The residue was taken up in $\mathrm{EtOH}$, subsequently passed through Dowex- $\mathrm{H}^{+}$and Dowex- $\mathrm{OH}^{-}$resin columns by eluting with $\mathrm{EtOH}$, concentrated and purified by silica gel chromatography (EtOAc/MeOH, 100/0 to 97/3, v/v) to obtain carbamate 28b (20 mg, $0.12 \mathrm{mmol}, 25 \%)$ and a mixture of 28a and 31 (60 mg, $0.36 \mathrm{mmol}$, $75 \%)$ as amorphous white powders. Carbamate 28a: $\mathrm{R}_{f}=0.21(\mathrm{MeOH} / \mathrm{EtOAc}$, 2/8, v/v); IR (film): 3419, 3385, 2928, 2856, 1710, 1662, 1393, 1267, 1125, 1073, 1046, 1013, 883, $740 \mathrm{~cm}^{-1} ;{ }^{1} \mathrm{H}$ NMR $\left(500 \mathrm{MHz}, \mathrm{D}_{2} \mathrm{O}\right) \delta 4.47\left(\mathrm{t}, J_{5,6 \mathrm{a}}=J_{6 \mathrm{a}, 6 \mathrm{~b}}=9.0\right.$ $\mathrm{Hz}, 1 \mathrm{H}, \mathrm{H}-6 \mathrm{a}), 4.35$ (dd, $\left.J_{5,6 \mathrm{~b}}=5.0, J_{6 \mathrm{a}, 6 \mathrm{~b}}=9.0 \mathrm{~Hz}, 1 \mathrm{H}, \mathrm{H}-6 \mathrm{~b}\right), 4.05$ (ddd, $J_{4,5}=$ $\left.1.9, J_{5,6 \mathrm{~b}}=5.0, J_{5,6 \mathrm{a}}=9.0 \mathrm{~Hz}, 1 \mathrm{H}, \mathrm{H}-5\right), 3.96\left(\mathrm{dd}, J_{4,5}=1.9, J_{3,4}=2.3 \mathrm{~Hz}, 1 \mathrm{H}, \mathrm{H}-\right.$ 4), $3.90\left(\mathrm{dd}, J_{1 \mathrm{a}, 2}=6.1, J_{1 \mathrm{a}, 1 \mathrm{~b}}=13.1 \mathrm{~Hz}, 1 \mathrm{H}, \mathrm{H}-1 \mathrm{a}\right), 3.79\left(\mathrm{ddd}, J_{1 \mathrm{a}, 2}=6.1, J_{2,3}=\right.$ 9.7, $\left.J_{1 \mathrm{~b}, 2}=10.5 \mathrm{~Hz}, 1 \mathrm{H}, \mathrm{H}-2\right), 3.57\left(\mathrm{dd}, J_{3,4}=2.3, J_{2,3}=9.7 \mathrm{~Hz}, 1 \mathrm{H}, \mathrm{H}-3\right), 2.82$ $\left(\mathrm{dd}, J_{1 \mathrm{~b}, 2}=10.5, J_{1 \mathrm{a}, 1 \mathrm{~b}}=13.1 \mathrm{~Hz}, 1 \mathrm{H}, \mathrm{H}-1 \mathrm{~b}\right) ;{ }^{13} \mathrm{C} \mathrm{NMR}\left(125 \mathrm{MHz}, \mathrm{D}_{2} \mathrm{O}\right) \delta 159.7$ (C7), 73.6 (C3), 69.0 (C4), 65.0 (C2), 63.9 (C6), 56.6 (C5), 44.0 (C1). HRMS(ESI) $\mathrm{m} / z$ calcd. for $\left[\mathrm{C}_{7} \mathrm{H}_{11} \mathrm{O}_{5} \mathrm{~N}+\mathrm{Na}\right]^{+}:$212.0535, obsd.: 212.0532 . Carbamate 28b: $\mathrm{R}_{f}=0.28(\mathrm{MeOH} / \mathrm{EtOAc}, 2 / 8$, v/v); IR (film): 3353, 3204, 2931, 2856, 1730, 1448, 1262, 1124, 1087, 1046, 1013, $996 \mathrm{~cm}^{-1} ;{ }^{1} \mathrm{H}$ NMR (500 MHz, $\left.\mathrm{D}_{2} \mathrm{O}\right) \delta 4.43\left(\mathrm{t}, J_{5,6 \mathrm{a}}=J_{6 \mathrm{a}, 6 \mathrm{~b}}=8.8 \mathrm{~Hz}, 1 \mathrm{H}, \mathrm{H}-6 \mathrm{a}\right), 4.18\left(\mathrm{dd}, J_{5,6 \mathrm{~b}}=5.1, J_{6 \mathrm{a}, 6 \mathrm{~b}}=8.8\right.$ $\mathrm{Hz}, 1 \mathrm{H}, \mathrm{H}-6 \mathrm{~b}), 3.89-3.85$ (m, 2H, H-2 and H-3), 3.80 (ddd, $J_{4,5}=10.2, J_{5,6 \mathrm{a}}=8.8$, $\left.J_{5,6 \mathrm{~b}}=5.1 \mathrm{~Hz}, 1 \mathrm{H}, \mathrm{H}-5\right), 3.71\left(\mathrm{dd}, J_{4,5}=10.2, J_{3,4}=2.5 \mathrm{~Hz}, 1 \mathrm{H}, \mathrm{H}-4\right), 3.90$ (bd, $\left.J_{1 \mathrm{a}, 1 \mathrm{~b}}=14.3 \mathrm{~Hz}, 1 \mathrm{H}, \mathrm{H}-1 \mathrm{a}\right), 3.21\left(\mathrm{dd}, J_{1 \mathrm{a}, 1 \mathrm{~b}}=14.3, J_{1 \mathrm{~b}, 2}=1.6 \mathrm{~Hz}, 1 \mathrm{H}, \mathrm{H}-1 \mathrm{~b}\right) ;{ }^{13} \mathrm{C}$ NMR (100MHz, D $2 \mathrm{O}) \delta 159.7(\mathrm{C}=\mathrm{O}), 70.0$ (C3), 68.3 (C2), 67.7 (C4), 67.0 (C6), 53.4 (C5), 41.7 (C1); HRMS(ESI) $m / z$ calcd. for $\left[\mathrm{C}_{7} \mathrm{H}_{11} \mathrm{O}_{5} \mathrm{~N}+\mathrm{Na}\right]^{+}:$212.0535, obsd.: 212.0529. Carbamate 31: $\mathrm{R}_{f}=0.21(\mathrm{MeOH} / \mathrm{EtOAc}, 2 / 8, \mathrm{v} / \mathrm{v})$; IR (film): 3419, 3385, 2928, 2856, 1710, 1662, 1393, 1267, 1125, 1073, 1046, 1013, 883, $740 \mathrm{~cm}^{-1}$; ${ }^{1} \mathrm{H}$ NMR (500 MHz, D $\left.2 \mathrm{O}\right) \delta 4.23-4.21(\mathrm{~m}, 1 \mathrm{H}, \mathrm{H}-6 \mathrm{a}), 4.14\left(\mathrm{~d}, J_{1 \mathrm{a}, 2}=\right.$ 4.6 Hz, 1H, H-2), 4.12 (d, $\left.J_{3,4}=2.8 \mathrm{~Hz}, 1 \mathrm{H}, \mathrm{H}-3\right), 4.02-3.95$ (m, 2H, H-5 and H$6 \mathrm{~b}), 3.62\left(\mathrm{dd}, J_{1 \mathrm{a}, 1 \mathrm{~b}}=12.6, J_{1 \mathrm{a}, 2}=4.6 \mathrm{~Hz}, 1 \mathrm{H}, \mathrm{H}-1 \mathrm{a}\right), 3.61-3.58(\mathrm{~m}, 1 \mathrm{H}, \mathrm{H}-4), 3.23$ (brd, $\left.J_{1 \mathrm{a}, 1 \mathrm{~b}}=12.6 \mathrm{~Hz}, 1 \mathrm{H}, \mathrm{H}-1 \mathrm{a}\right) ;{ }^{13} \mathrm{C}$ NMR $\left(125 \mathrm{MHz}, \mathrm{D}_{2} \mathrm{O}\right) \delta 155.0(\mathrm{C}=\mathrm{O}), 73.6$ (C2), 72.5 (C3), 69.1 (C6), 62.8 (C4), 58.7 (C5), 53.0 (C1); HRMS(ESI) m/z calcd. for $\left[\mathrm{C}_{7} \mathrm{H}_{11} \mathrm{O}_{5} \mathrm{~N}+\mathrm{Na}\right]^{+}:$212.0533, obsd.: 212.0529 . 
<smiles>O=C1OC[C@H]2[C@@H](O)C(O)CCN12</smiles>

(7R,8S,8a $R)$-7,8-Dihydroxy-hexahydro-oxazolo $[3,4-a]$ pyridin3(5H)-one (47a). To a solution of alkenylamine hydrochloride $46(17 \mathrm{mg}, 0.13$ mmol) in sat. aq. $\mathrm{NaHCO}_{3}(0.6 \mathrm{ml}), \mathrm{I}_{2}(32 \mathrm{mg}, 0.25 \mathrm{mmol})$ was added. The solution was stirred $24 \mathrm{~h}$ at $50{ }^{\circ} \mathrm{C}$ then filtered and concentrated in vacuo. Purification by flash chromatography (EtOAc/MeOH, 99/1, v/v) yielded carbamate 47a. $(15.1 \mathrm{mg}, 0.0873 \mathrm{mmol}, 86 \%) \cdot[\alpha]_{\mathrm{D}}{ }^{19}=+4.0(\mathrm{c}=1.0, \mathrm{MeOH})$; IR (film) 3338, 2945, 2360, 2342, 1653, 1449, 1417, 1114, $1021 \mathrm{~cm}^{-1} ;{ }^{1} \mathrm{H}$ NMR $\left(500 \mathrm{MHz}, \mathrm{D}_{2} \mathrm{O}\right) \delta 4.34\left(\mathrm{t}, J_{5,6}=J_{6 \mathrm{a}, 6 \mathrm{~b}}=9.0 \mathrm{~Hz}, 1 \mathrm{H}, \mathrm{H}-6 \mathrm{a}\right), 4.22\left(\mathrm{dd}, J_{5,6}=5.5\right.$, $\left.J_{6 \mathrm{a}, 6 \mathrm{~b}}=9.0 \mathrm{~Hz}, 1 \mathrm{H}, \mathrm{H}-6 \mathrm{~b}\right), 3.89\left(\mathrm{ddd}, J_{4,5}=1.8, J_{5,6 \mathrm{~b}}=5.5, J_{5,6 \mathrm{a}}=9.0 \mathrm{~Hz}, 1 \mathrm{H}, \mathrm{H}-\right.$ 5), 3.75 (br s, $1 \mathrm{H}, \mathrm{H}-4), 3.72\left(\mathrm{ddd}, J_{3,4}=2.5, J_{2 \mathrm{~b}, 3}=5.5, J_{2 \mathrm{a}, 3}=11.1 \mathrm{~Hz}, 1 \mathrm{H}, \mathrm{H}-3\right.$ ), $3.63\left(\mathrm{ddd}, J_{1 \mathrm{a}, 2 \mathrm{~b}}=1.9, J_{1 \mathrm{a}, 2 \mathrm{a}}=5.3, J_{1 \mathrm{a}, 1 \mathrm{~b}}=13.6 \mathrm{~Hz}, 1 \mathrm{H}, \mathrm{H}-1 \mathrm{a}\right), 2.92\left(\mathrm{ddd}, J_{1 \mathrm{~b}, 2 \mathrm{~b}}=\right.$ $\left.4.5 J_{1 \mathrm{~b}, 2 \mathrm{a}}=12.0, J_{1 \mathrm{a}, 1 \mathrm{~b}}=13.6 \mathrm{~Hz}, 1 \mathrm{H}, \mathrm{H}-1 \mathrm{~b}\right), 1.62(\mathrm{~m}, 2 \mathrm{H}, \mathrm{H}-2 \mathrm{a}$ and $\mathrm{H}-2 \mathrm{~b}) .{ }^{13} \mathrm{C}$ NMR (125 MHz, $\left.\mathrm{D}_{2} \mathrm{O}\right) \delta 159.5(\mathrm{C}=\mathrm{O}) 68.6(\mathrm{C} 3), 67.9$ (C4), 64.1 (C6), 57.0 (C5), 38.5 (C1), 25.1 (C2); HRMS(ESI) m/z calcd. For $\left[\mathrm{C}_{7} \mathrm{H}_{11} \mathrm{NO}_{4}+\mathrm{Na}\right]^{+}: 196.0580$, obsd.: 196.0590 .

\section{General procedure for the synthesis of azasugars.}

To a solution of carbamate $(159 \mathrm{mg}, 1 \mathrm{mmol})$ in $\mathrm{EtOH}(5 \mathrm{~mL})$ was added $\mathrm{NaOH}$ (400 mg, $10 \mathrm{mmol}$ ). The solution was stirred at reflux for $2 \mathrm{~h}$ then cooled and purified directly using Dowex $\left(\mathrm{H}^{+}\right)$. The product was eluted in 5 to $15 \%$ aqueous $\mathrm{NH}_{3}$ and concentrated under reduced pressure. The isolated compound was converted to the $\mathrm{HCl}$ salt, using $1 \mathrm{M} \mathrm{HCl}$, for characterisation.<smiles>OC[C@H]1CCCN1</smiles>

$\mathrm{HO}$ " $\mathrm{OH}$ 1,4-dideoxy-1,4-imino-L-lyxitol (2). By subjecting cyclic carbamate $11(6.4 \mathrm{mg}, 40 \mu \mathrm{mol})$ to the general procedure for the synthesis of azasugars, 2 was isolated as the $\mathrm{HCl}$ salt $(6.6 \mathrm{mg}, 39 \mu \mathrm{mol}, 97 \%) . \mathrm{R}_{f}=0.11$ (DCM/EtOH/MeOH/30\% aqueous $\left.\mathrm{NH}_{3}, 5 / 2 / 2 / 1, \mathrm{v} / \mathrm{v} / \mathrm{v} / \mathrm{v}\right) ;[\alpha]_{\mathrm{D}}{ }^{19}=-22.4(c=0.3$, $\mathrm{H}_{2} \mathrm{O}$ ); IR (film) 3369, 3198, 2956, 2857, 1456, 1266, 1127, $1056 \mathrm{~cm}^{-1} .{ }^{1} \mathrm{H}$ NMR $\left(500 \mathrm{MHz}, \mathrm{D}_{2} \mathrm{O}\right) \delta 4.47\left(\mathrm{dt}, J_{2,3}=4.1, J_{1 \mathrm{a}, 2}=J_{1 \mathrm{~b}, 2}=7.4 \mathrm{~Hz}, 1 \mathrm{H}, \mathrm{H}-2\right), 4.32\left(\mathrm{t}, J_{2,3}\right.$ 
$\left.=J_{3,4}=4.2 \mathrm{~Hz}, 1 \mathrm{H}, \mathrm{H}-3\right), 3.96\left(\mathrm{dd}, J_{4,5 \mathrm{a}}=5.0, J_{5 \mathrm{a}, 5 \mathrm{~b}}=12.1 \mathrm{~Hz}, 1 \mathrm{H}, \mathrm{H}-5 \mathrm{a}\right), 3.86$ $\left(\mathrm{dd}, J_{4,5 \mathrm{~b}}=8.4, J_{5 \mathrm{a}, 5 \mathrm{~b}}=12.1 \mathrm{~Hz}, 1 \mathrm{H}, \mathrm{H}-5 \mathrm{~b}\right), 3.71\left(\mathrm{ddd}, J_{3,4}=4.2, J_{4,5 \mathrm{a}}=5.0, J_{4,5 \mathrm{~b}}=\right.$ $8.4 \mathrm{~Hz}, 1 \mathrm{H}, \mathrm{H}-4), 3.50$ (dd, $\left.J_{1 \mathrm{a}, 2}=7.4, J_{1 \mathrm{a}, 1 \mathrm{~b}}=12.2 \mathrm{~Hz}, 1 \mathrm{H}, \mathrm{H}-1 \mathrm{a}\right), 3.18\left(\mathrm{dd}, J_{1 \mathrm{~b}, 2}=\right.$ 7.4, $\left.J_{1 \mathrm{a}, 1 \mathrm{~b}}=12.2 \mathrm{~Hz}, 1 \mathrm{H}, \mathrm{H}-1 \mathrm{~b}\right) ;{ }^{13} \mathrm{C} \mathrm{NMR}\left(125 \mathrm{MHz}, \mathrm{D}_{2} \mathrm{O}\right) \delta 69.9$ (C2), 69.7 (C3), 62.4 (C4), 57.6 (C5), 46.9 (C1); HRMS(ESI) $m / z$ calcd. for $\left[\mathrm{C}_{5} \mathrm{H}_{11} \mathrm{O}_{3} \mathrm{~N}+\mathrm{H}\right]^{+}:$134.0812, obsd.: 134.0813 .<smiles>OC[C@H]1NCC(O)[C@@H]1O</smiles>

1,4-dideoxy-1,4-imino-L-xylitol (3). By subjecting cyclic carbamate $16(13 \mathrm{mg}, 0.082 \mathrm{mmol})$ to the general procedure for the synthesis of azasugars, 3 was isolated as the $\mathrm{HCl}$ salt $\left(13 \mathrm{mg}, 0.077 \mathrm{mmol}, 97 \%\right.$ ). $\mathrm{R}_{f}=0.21$ $\left(\mathrm{DCM} / \mathrm{EtOH} / \mathrm{MeOH} / 30 \%\right.$ aqueous $\left.\mathrm{NH}_{3}, 5 / 2 / 2 / 1, \mathrm{v} / \mathrm{v} / \mathrm{v} / \mathrm{v}\right) ;[\alpha]_{\mathrm{D}}{ }^{20}=+8.2(c=0.5$, $\mathrm{H}_{2} \mathrm{O}$ ); IR (film) 3317, 2944, 2832, 1654, 1449, 1415, 1113, $1021 \mathrm{~cm}^{-1}$; ${ }^{1} \mathrm{H}$ NMR $\left(500 \mathrm{MHz}, \mathrm{D}_{2} \mathrm{O}\right) \delta 4.26\left(\mathrm{~d}, J_{1 \mathrm{a}, 2}=4.5 \mathrm{~Hz}, 1 \mathrm{H}, \mathrm{H}-2\right), 4.19$ (d, $J_{3,4}=3.8 \mathrm{~Hz}, 1 \mathrm{H}, \mathrm{H}-$ 3), $3.89\left(\mathrm{dd}, J_{4,5 \mathrm{a}}=5.5, J_{5 \mathrm{a}, 5 \mathrm{~b}}=11.5 \mathrm{~Hz}, 1 \mathrm{H}, \mathrm{H}-5 \mathrm{a}\right), 3.77\left(\mathrm{dd}, J_{4,5 \mathrm{~b}}=7.7, J_{5 \mathrm{a}, 5 \mathrm{~b}}=\right.$ $11.5 \mathrm{~Hz}, 1 \mathrm{H}, \mathrm{H}-5 \mathrm{~b}$ ), 3.62 (ddd, $\left.J_{3,4}=3.8, J_{4,5 \mathrm{a}}=5.5, J_{4,5 \mathrm{~b}}=7.7 \mathrm{~Hz}, 1 \mathrm{H}, \mathrm{H}-4\right), 3.46$ $\left(\mathrm{dd}, J_{1 \mathrm{a}, 2}=4.5, J_{1 \mathrm{a}, 1 \mathrm{~b}}=12.8 \mathrm{~Hz}, 1 \mathrm{H}, \mathrm{H}-1 \mathrm{a}\right), 3.04\left(\mathrm{~d}, J_{1 \mathrm{a}, 1 \mathrm{~b}}=12.8 \mathrm{~Hz}, 1 \mathrm{H}, \mathrm{H}-1 \mathrm{~b}\right)$; ${ }^{13} \mathrm{C}$ NMR (125 MHz, D $\left.\mathrm{O}\right) \delta 74.6$ (C2), 74.5 (C3), 62.5 (C4), 57.6 (C5), 50.4 (C1); HRMS(ESI) $m / z$ calcd. For $\left[\mathrm{C}_{5} \mathrm{H}_{11} \mathrm{O}_{3} \mathrm{~N}+\mathrm{H}\right]^{+}: 134.0812$, obsd.: 134.0817.<smiles>OC[C@@H]1NCC[C@H]1O</smiles>

1,2,4-trideoxy-1,4-imino-L-arabinitol (4). By subjecting carbamate $21(10 \mathrm{mg}, 0.07 \mathrm{mmol})$ to the general procedure for the synthesis of azasugars, 4 was isolated as the $\mathrm{HCl}$ salt $\left(8.2 \mathrm{mg}, 0.07\right.$ mmol, 99\%). $\mathrm{R}_{f}=0.1$ $\left(\mathrm{DCM} / \mathrm{EtOH} / \mathrm{MeOH} / 30 \%\right.$ aqueous $\left.\mathrm{NH}_{3}, 5 / 2 / 2 / 1, \mathrm{v} / \mathrm{v} / \mathrm{v} / \mathrm{v}\right) ;[\alpha]_{\mathrm{D}}{ }^{17}=+10.0(\mathrm{c}=$ 0.09, MeOH); IR (film), 3397, 3364, 2960, 2932, 2874, 1720, 1601, 1168, 1064 $\mathrm{cm}^{-1} ;{ }^{1} \mathrm{H}$ NMR $\left(500 \mathrm{MHz}, \mathrm{D}_{2} \mathrm{O}\right) \delta 4.27\left(\mathrm{dt}, J_{2 \mathrm{~b}, 3}=1.5, J_{2 \mathrm{a}, 3}=J_{3,4}=4.9 \mathrm{~Hz}, 1 \mathrm{H}, \mathrm{H}-\right.$ 3), $3.98\left(\mathrm{dd}, J_{4,5 \mathrm{a}}=4.9, J_{5 \mathrm{a}, 5 \mathrm{~b}}=12.1 \mathrm{~Hz}, 1 \mathrm{H}, \mathrm{H}-5 \mathrm{a}\right), 3.83\left(\mathrm{dd}, J_{4,5 \mathrm{~b}}=8.5, J_{5 \mathrm{a}, 5 \mathrm{~b}}=\right.$ $12.1 \mathrm{~Hz}, 1 \mathrm{H}, \mathrm{H}-5 \mathrm{~b}), 3.31\left(\mathrm{td}, J_{3,4}=J_{4,5 \mathrm{a}}=4.9, J_{4,5 \mathrm{~b}}=8.5 \mathrm{~Hz}, 1 \mathrm{H}, \mathrm{H}-4\right), 3.25$ (ddd, $\left.J_{1 \mathrm{a}, 2 \mathrm{~b}}=7.6, J_{1 \mathrm{a}, 2 \mathrm{a}}=9.6, J_{1 \mathrm{a}, 1 \mathrm{~b}}=11.6 \mathrm{~Hz}, 1 \mathrm{H}, \mathrm{H}-1 \mathrm{a}\right), 3.21\left(\mathrm{ddd}, J_{1 \mathrm{~b}, 2 \mathrm{~b}}=3.4, J_{1 \mathrm{~b}, 2 \mathrm{a}}=\right.$ 9.9, $\left.J_{1 \mathrm{a}, 1 \mathrm{~b}}=11.6 \mathrm{~Hz}, 1 \mathrm{H}, \mathrm{H}-1 \mathrm{~b}\right), 2.13\left(\mathrm{dddd}, J_{2 \mathrm{a}, 3}=4.9, J_{2 \mathrm{a}, 1 \mathrm{a}}=9.6, J_{2 \mathrm{a}, 1 \mathrm{~b}}=9.9\right.$, 
$\left.J_{2 \mathrm{a}, 2 \mathrm{~b}}=14.1 \mathrm{~Hz}, 1 \mathrm{H}, \mathrm{H}-2 \mathrm{a}\right), 2.05\left(\mathrm{dddd}, J_{2 \mathrm{~b}, 3}=1.5, J_{2 \mathrm{~b}, 1 \mathrm{~b}}=3.4, J_{2 \mathrm{~b}, 1 \mathrm{a}}=7.6, J_{2 \mathrm{a}, 2 \mathrm{~b}}=\right.$ 14.1 Hz, 1H, H-2b); ${ }^{13} \mathrm{C}$ NMR (125 MHz, D $\left.2 \mathrm{O}\right) \delta 70.8$ (C3), 64.1 (C4), 59.0 (C5), 42.9 (C2), 33.3 (C1). HRMS(ESI) $m / z$ calcd. for $\left[\mathrm{C}_{5} \mathrm{H}_{11} \mathrm{NO}_{2}+\mathrm{H}\right]^{+}: 118.0863$ obsd.: 118.0870 .<smiles>OC[C@H]1NC[C@@H](O)[C@H](O)[C@@H]1O</smiles>

Deoxygalactonojirimycin (5). A 1:1 mixture of carbamates 28a and 31 (20 mg, $0.12 \mathrm{mmol})$ and $\mathrm{NaOH}(200 \mathrm{mg})$ were dissolved in $\mathrm{EtOH}$ and refluxed for $2 \mathrm{~h}$. The reaction was cooled to rt, loaded onto a Dowex- $\mathrm{H}^{+}$column, eluted with $50 \%$ conc. aq. $\mathrm{NH}_{3}$ in EtOH and concentrated. Purification of the residue by column chromatography gave the title compound $(10 \mathrm{mg}, 0.06 \mathrm{mmol}$, quant.) as a white solid. $\mathrm{R}_{f}=0.1\left(\mathrm{DCM} / \mathrm{EtOH} / \mathrm{MeOH} / 30 \%\right.$ aqueous $\mathrm{NH}_{3}, 5 / 2 / 2 / 1$, $\mathrm{v} / \mathrm{v} / \mathrm{v} / \mathrm{v}) ;{ }^{1} \mathrm{H}$ NMR $\left(300 \mathrm{MHz}, \mathrm{D}_{2} \mathrm{O}\right) \delta 4.13\left(\mathrm{dd}, J_{4,5}=1.4, J_{3,4}=3.2 \mathrm{~Hz}, 1 \mathrm{H}, \mathrm{H}-4\right)$, $4.04\left(\mathrm{ddd}, J_{1 \mathrm{a}, 2}=5.4, J_{1 \mathrm{~b}, 2}=10.9 \mathrm{~Hz}, J_{2,3}=9.7 \mathrm{~Hz}, 1 \mathrm{H}, \mathrm{H}-2\right), 3.85\left(\mathrm{dd}, J_{5,6 \mathrm{a}}=6.7\right.$, $\left.J_{6 \mathrm{a}, 6 \mathrm{~b}}=11.2 \mathrm{~Hz}, 1 \mathrm{H}, \mathrm{H}-6 \mathrm{a}\right), 3.77\left(\mathrm{dd}, J_{5,6 \mathrm{~b}}=6.7, J_{6 \mathrm{a}, 6 \mathrm{~b}}=11.2 \mathrm{~Hz}, 1 \mathrm{H}, \mathrm{H}-6 \mathrm{~b}\right), 3.60$ $\left(\mathrm{dd}, J_{2,3}=9.7, J_{3,4}=3.2 \mathrm{~Hz}, 1 \mathrm{H}, \mathrm{H}-3\right), 3.48\left(\mathrm{dd}, J_{1 \mathrm{a}, 2}=5.4, J_{1 \mathrm{a}, 1 \mathrm{~b}}=12.7 \mathrm{~Hz}, 1 \mathrm{H}\right.$, $\mathrm{H}-1 \mathrm{a}), 3.39\left(\mathrm{dt}, J_{4,5}=1.4, J_{5,6 \mathrm{a}}=J_{5,6 \mathrm{~b}}=6.7 \mathrm{~Hz}, 1 \mathrm{H}, \mathrm{H}-5\right), 2.84\left(\mathrm{dd}, J_{1 \mathrm{a}, 1 \mathrm{~b}}=12.7\right.$, $J_{1 b, 2}=10.9 \mathrm{~Hz}, 1 \mathrm{H}, \mathrm{H}-1 \mathrm{~b}$ ); HRMS(ESI) $\mathrm{m} / z$ calcd. for $\left[\mathrm{C}_{6} \mathrm{H}_{13} \mathrm{O}_{4} \mathrm{~N}+\mathrm{H}\right]^{+}: 164.0917$, obsd.: 164.0916 .<smiles>NC[C@H]1O[C@H](CI)[C@@H](O)[C@H]1O</smiles>

To a solution of alkenylamine $34(310 \mathrm{mg}, 1.69 \mathrm{mmol})$ in sat. aq. $\mathrm{NaHCO}_{3}(7 \mathrm{~mL})$ was added $\mathrm{I}_{2}(645 \mathrm{mg}, 2.54 \mathrm{mmol})$ and the solution was stirred 7 days. The reaction mixture was concentrated and used without further purification. $\mathrm{R}_{f}=0.23$ (DCM/EtOH/MeOH/30\% aq. $\left.\mathrm{NH}_{3}, 5 / 2 / 2 / 1, \mathrm{v} / \mathrm{v} / \mathrm{v} / \mathrm{v}\right) ;{ }^{1} \mathrm{H}$ NMR $\left(500 \mathrm{MHz}, \mathrm{D}_{2} \mathrm{O}\right) \delta$ $4.45\left(\mathrm{dt}, J_{4,5}=3.1, J_{5,6 \mathrm{a}}=J_{5,6 \mathrm{~b}}=7.3 \mathrm{~Hz}, 1 \mathrm{H}, \mathrm{H}-5\right), 4.40\left(\mathrm{ddd}, J_{2,3}=3.8, J_{1 \mathrm{a}, 2}=4.4\right.$, $\left.J_{1 \mathrm{~b}, 2}=5.6 \mathrm{~Hz}, 1 \mathrm{H}, \mathrm{H}-2\right), 4.38\left(\mathrm{dd}, J_{3,4}=1.3, J_{2,3}=3.8 \mathrm{~Hz}, 1 \mathrm{H}, \mathrm{H}-3\right), 4.28\left(\mathrm{dd}, J_{3,4}\right.$ $\left.=1.3, J_{4,5}=3.1 \mathrm{~Hz}, 1 \mathrm{H}, \mathrm{H}-4\right), 3.27\left(\mathrm{dd}, J_{5,6 \mathrm{a}}=7.3, J_{6 \mathrm{a}, 6 \mathrm{~b}}=9.8 \mathrm{~Hz}, 1 \mathrm{H}, \mathrm{H}-6 \mathrm{a}\right), 3.26$ 
$\left(\mathrm{dd}, J_{5,6 \mathrm{~b}}=7.3, J_{6 \mathrm{a}, 6 \mathrm{~b}}=9.8 \mathrm{~Hz}, 1 \mathrm{H}, \mathrm{H}-6 \mathrm{~b}\right), 3.258\left(\mathrm{dd}, J_{1 \mathrm{a}, 2}=4.4, J_{1 \mathrm{a}, 1 \mathrm{~b}}=13.6 \mathrm{~Hz}\right.$, $1 \mathrm{H}, \mathrm{H}-1 \mathrm{a}), 3.23\left(\mathrm{dd}, J_{1 \mathrm{~b}, 2}=5.6, J_{1 \mathrm{a}, 1 \mathrm{~b}}=13.6 \mathrm{~Hz}, 1 \mathrm{H}, \mathrm{H}-1 \mathrm{~b}\right) ;{ }^{13} \mathrm{C} \mathrm{NMR}(125 \mathrm{MHz}$, $\left.\mathrm{D}_{2} \mathrm{O}\right) \delta 81.7$ (C5), 77.5 (C3), 76.52, 76.50 (C2 and C4), 39.4 (C1), 0.6 (C6); HRMS(ESI) $m / z$ calcd. for $\left[\mathrm{C}_{6} \mathrm{H}_{12} \mathrm{O}_{3} \mathrm{NI}+\mathrm{H}\right]^{+}: 273.9935$, obsd.: 273.9938.<smiles>CCCCCCNCC1O[C@@H](CI)C(OC(C)=O)C1OC(C)=O</smiles>

\section{1-Acetamido-3,4-di-O-acetyl-2,5-anhydro-1,6-dideoxy-6-}

iodo-L-iditol (37). A solution of iditol 35 was stirred over night at rt in a solution of Acetic anhydride $(4 \mathrm{~mL})$ and pyridine $(4 \mathrm{~mL})$. The reaction mixture was concentrated, the dissolved in EtOAc and washed sat. aq. $\mathrm{NaHCO}_{3}$ and brine, dried $\mathrm{MgSO}_{4}$, filtered and concentrated in vacuo to give acetylated iditol 37 as the major product. $\mathrm{R}_{f}=0.12\left(\right.$ EtOAc); ${ }^{1} \mathrm{H} \mathrm{NMR}\left(500 \mathrm{MHz}, \mathrm{CDCl}_{3}\right) \delta 5.84\left(\mathrm{t}, J_{1 \mathrm{a}, \mathrm{NH}}=\right.$ $\left.J_{1 \mathrm{~b}, \mathrm{NH}}=6.2 \mathrm{~Hz}, 1 \mathrm{H}, \mathrm{NH}\right), 5.38\left(\mathrm{dd}, J_{3,4}=1.4, J_{4,5}=4.0 \mathrm{~Hz}, 1 \mathrm{H}, \mathrm{H}-4\right), 5.27(\mathrm{dd}$, $\left.J_{3,4}=1.4, J_{2,3}=3.4 \mathrm{~Hz}, 1 \mathrm{H}, \mathrm{H}-3\right), 4.52\left(\mathrm{ddd}, J_{4,5}=4.0, J_{5,6 \mathrm{a}}=6.3, J_{5,6 \mathrm{~b}}=8.8 \mathrm{~Hz}\right.$, $1 \mathrm{H}, \mathrm{H}-5), 4.30\left(\mathrm{ddd}, J_{2,3}=3.4, J_{1 \mathrm{~b}, 2}=6.2, J_{1 \mathrm{a}, 2}=7.3 \mathrm{~Hz}, 1 \mathrm{H}, \mathrm{H}-2\right), 3.47$ (ddd, $\left.J_{1 \mathrm{a}, \mathrm{NH}}=6.2, J_{1 \mathrm{a}, 2}=7.3, J_{1 \mathrm{a}, 1 \mathrm{~b}}=14.0 \mathrm{~Hz}, 1 \mathrm{H}, \mathrm{H}-1 \mathrm{a}\right), 3.27\left(\mathrm{td}, J_{1 \mathrm{~b}, \mathrm{NH}}=J_{1 \mathrm{~b}, 2}=6.2\right.$, $\left.J_{1 \mathrm{a}, 1 \mathrm{~b}}=14.0 \mathrm{~Hz}, 1 \mathrm{H}, \mathrm{H}-1 \mathrm{~b}\right), 3.21\left(\mathrm{dd}, J_{5,6 \mathrm{a}}=6.3, J_{6 \mathrm{a}, 6 \mathrm{~b}}=9.7 \mathrm{~Hz}, 1 \mathrm{H}, \mathrm{H}-6 \mathrm{a}\right), 3.17$ $\left(\mathrm{dd}, J_{5,6 \mathrm{~b}}=8.8, J_{6 \mathrm{a}, 6 \mathrm{~b}}=9.7 \mathrm{~Hz}, 1 \mathrm{H}, \mathrm{H}-6 \mathrm{~b}\right) ;{ }^{13} \mathrm{C} \mathrm{NMR}\left(125 \mathrm{MHz}, \mathrm{CDCl}_{3}\right) \delta 79.6$ (C5), 78.9 (C2), 76.4 (C3), 76.1 (C4), 38.1 (C1), -0.6 (C6); HRMS(ESI) m/z calcd. for $\left[\mathrm{C}_{12} \mathrm{H}_{19} \mathrm{O}_{6} \mathrm{NI}+\mathrm{Na}\right]^{+}: 422.0071$, obsd.: 422.0076 .

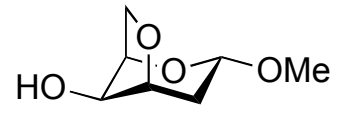

Methyl 3,6-anhydro-2-deoxy-a-D-galactopyranoside (42). $\mathrm{R}_{f}=0.3\left(\right.$ EtOAc/MeOH, 98/2, v/v); ${ }^{1} \mathrm{H}$ NMR $\left(500 \mathrm{MHz}, \mathrm{D}_{2} \mathrm{O}\right) \delta 4.69\left(\mathrm{~d}, J_{1,2 \mathrm{~b}}=\right.$ $6.2 \mathrm{~Hz}, 1 \mathrm{H}, \mathrm{H}-1), 4.31-4.32$ (m, 2H, H-3 and H-6a), 4.27-4.28 (m, 1H, H-5), 4.02 $\left(\mathrm{d}, J_{3,4}=1.8 \mathrm{~Hz}, 1 \mathrm{H}, \mathrm{H}-4\right), 3.98\left(\mathrm{dd}, J_{5,6 \mathrm{~b}}=3.4, J_{6 \mathrm{a}, 6 \mathrm{~b}}=9.9 \mathrm{~Hz}, 1 \mathrm{H}, \mathrm{H}-6 \mathrm{~b}\right), 3.40(\mathrm{~s}$, $3 \mathrm{H}, \mathrm{OMe}), 2.19\left(\mathrm{dd}, J_{2 \mathrm{a}, 3}=4.6, J_{2 \mathrm{a}, 2 \mathrm{~b}}=14.5 \mathrm{~Hz}, 1 \mathrm{H}, \mathrm{H}-2 \mathrm{a}\right), 2.02\left(\mathrm{ddd}, J_{2 \mathrm{~b}, 3}=1.6\right.$, $\left.J_{1,2 \mathrm{~b}}=6.2, J_{2 \mathrm{a}, 2 \mathrm{~b}}=14.5 \mathrm{~Hz}, 1 \mathrm{H}, \mathrm{H}-2 \mathrm{~b}\right) ;{ }^{13} \mathrm{C} \mathrm{NMR}\left(125 \mathrm{MHz}, \mathrm{D}_{2} \mathrm{O}\right) \delta 97.2(\mathrm{C} 1)$, 77.8 (C3), 77.3 (C5), 74.8 (C4), 70.2 (C6), 55.7 (OMe), 37.6 (C2); HRMS(ESI) $m / z$ calcd. for $\left[\mathrm{C}_{7} \mathrm{H}_{12} \mathrm{O}_{4}+\mathrm{Na}\right]^{+}: 183.0633$, obsd.: 183.0631 . 


\subsection{References}

(1) Dangerfield, E. M.; Plunkett, C. H.; Stocker, B. L.; Timmer, M. S. M. Molecules 2009, 14, 5298-5307.

(2) Dangerfield, E. M.; Gulab, S. A.; Plunkett, C. H.; Timmer, M. S. M.; Stocker, B. L. Carbohydr. Res. 2010, 345, 1360-1365.

(3) Dangerfield, E. M.; Plunkett, C. H.; Win-Mason, A. L.; Stocker, B. L.; Timmer, M. S. M. J. Org. Chem. 2010, 75, 5470-5477.

(4) Dangerfield, E. M.; Timmer, M. S. M.; Stocker, B. L. Org. Lett. 2009, 11, 535-538.

(5) Miniami, Y.; Kuriyama, C.; Ikeda, K.; Kato, A.; Takebayashi, K.; Adachi, I.; Fleet, G. W. J.; Kettawan, A.; Okamoto, T.; Asano, N. Bioorg. Med. Chem. 2008, 16, 2734-2740.

(6) Butters, T. D.; Dwek, R. A.; Platt, F. M. Glycobiology 2005, 15, 43R-52R.

(7) Asano, N.; Oseki, K.; Kizu, H.; Matsui, K. J. Med. Chem. 1994, 37, 37013706.

(8) Asano, N.; Ishii, S.; Kizu, H.; Ikeda, K.; Yasuda, K.; Kato, A.; Martin, O. R.; Fan, J.-Q. Eur. J. Biochem. 2000, 267, 4179-4186.

(9) Skaanderup, P. R.; Poulsen, C. S.; Hyldtoft, L.; Jørgensen, M. R.; Madsen, R. Synthesis 2002, 12, 1721-1727.

(10) Huang, Y.; Dalton, D. R.; Carroll, P. J. J. Org. Chem. 1997, 62, 372-376.

(11) Buchanan, J. G.; Lumbard, K. W.; Sturgeon, R. J.; Thompson, D. K.; Wightman, R. H. J. Chem. Soc. Perk. Trans. 1 1990, 699-706.

(12) Meng, Q.; Hesse, M. Helv. Chim. Acta. 1991, 74, 445-450.

(13) Hoffer, M. Chem. Ber. 1960, 93, 2777-2781.

(14) Wang, D.; Nugent, W. A. J. Org. Chem. 2007, 72, 7307-7312.

(15) Lee, H. J.; Kang, J. E.; Yang, M. S.; Kang, K. Y.; Park, K. H. Tetrahedron 2001, 57, 10071-10076.

(16) Merino, P.; Delso, I.; Tejero, T.; Cardona, F.; Marradi, M.; Faggi, E.; Parmeggiani, C.; Goti, A. Eur. J. Org. Chem. 2008, 2929-2947.

(17) Mascavage, L. M.; Lu, Q.; Vey, J.; Dalton, D. R.; Carroll, P. J. J. Org. Chem. 2001, 66, 3621-3626.

(18) Jurczak, J.; Prokopowicz, P.; Golebiowski, A. Tetrahedron Lett. 1993, 34, 7107-7110.

(19) Banks, M. R.; Blake, A. J.; Cadogan, J. I. G.; Dawson, I. M.; Gaur, S.; Gosney, I.; Gould, R. O.; Grant, K. J.; Hodgson, P. K. G. J. Chem. Soc. Chem. Commun. 1993, 1146-1148.

(20) Ballou, C. E.; Fischer, H. O. L. J. Am. Chem. Soc. 1954, 76, 3188-3193.

(21) Gulab, S. A.; Cheng, J. M. H.; Timmer, M. S. M.; Stocker, B. L.; Gainsford, G. J. Acta. Crysta. 2010, E66, O1724.

(22) McGhee, W.; Riley, D.; Christ, K.; Pan, Y.; Parnas, B. J. Org. Chem. 1995, 60, 2820-2830.

(23) Hampe, E. M.; Rudkevich, D. M. Tetrahedron 2003, 59, 9619-9625.

(24) Jones, M. J. Organic Chemistry; W.W. Norton \& Company, 1997.

(25) Casadei, M. A.; Galli, C.; Mandolini, L. J. Am. Chem. Soc. 1984, 106, 1051-1056.

(26) Galli, C.; Mandolini, L. Eur. J. Org. Chem. 2000, 3117-3125.

(27) Karaman, R. J. Mol. Struc-Theochem 2010, 939, 69-74. 
(28) Chamberlin, A. R.; Mulholland Jr, R. L.; Kahn, S. D.; Hehre, W. J. J. Am. Chem. Soc. 1987, 109, 672-677.

(29) Tredwell, M.; Luft, J. A. R.; Schuler, M.; Tenza, K.; Houk, K. N.; Gouverneur, V. Angew. Chem. Int. Ed. 2008, 47, 357-360.

(30) Munneke, S., VUW Masters Thesis, 2011.

(31) Takahata, H.; Banba, Y.; Ouchi, H.; Nemoto, H.; Kato, A.; Adachi, I. J. Org. Chem. 2003, 68, 3603-3607.

(32) Kumari, N.; Reddy, B. G.; Vankar, Y. D. Eur. J. Org. Chem. 2009, 160169.

(33) Bürgi, H. B.; Dunitz, J. D.; Shefter, E. J. Am. Chem. Soc. 1973, 95, 50655067.

(34) Davis, A. S.; Gates, N. J.; Lindsay, K. B.; Tang, M.; Pyne, S. G. Synlett 2004, 1, 49-52. 



\section{Chapter 7: Anti-Tubercular Activity of Azasugars and Linear Alkenylamines}

\subsection{Introduction}

Tuberculosis $(\mathrm{Tb})$ is caused by mycobacteria, most commonly Mycobacterium tuberculosis, and continues to be the leading cause of death by infectious disease. ${ }^{1}$ Annually, Tb kills more than 1.8 million people world-wide, and in New Zealand, there are between 350 and 400 new cases of $\mathrm{Tb}$ each year. ${ }^{2}$ There have been no new drugs developed for the treatment of $\mathrm{Tb}$ since the late 1960s, and the prevalence of multi and extreme drug resistant tuberculosis strains is increasing. ${ }^{3}$ An estimated one third of the world's population are infected with tuberculosis and, on average, $10 \%$ of infected people will develop active Tb. The high incidence of $M$. tuberculosis infection highlights the importance of new treatments to reduce the prevalence of this disease.

$\mathrm{Tb}$ is difficult to treat, requiring long courses of multiple antibiotics. Currently, the standard short course drug treatment for active tuberculosis is isoniazid, rifampin, pyrazinamide and ethambutol for two months, then isoniazid and rifampin alone for a further four months. ${ }^{4}$ A patient is considered cured after these six months, however, the relapse rate is 2 to $3 \%$. For latent $\mathrm{Tb}$, the standard treatment is six to nine months of isoniazid alone. ${ }^{4}$ The treatment of active $\mathrm{Tb}$ always involves a combination of several drugs. Regimens that use only one drug result in the rapid development of bacterial resistance and subsequent treatment failure..$^{5}$ Due to the lengthy therapy that relies on several drug combinations, patients with TB often do not complete the full drug course. ${ }^{1}$ Non-compliance increases the risk of drug resistant strains developing, thereby threatening the ability to treat and control the disease. Currently, there are many multi-drug 
resistant (MDR) and extreme-drug resistant (XDR) M. tuberculosis strains. MDR is defined as resistance to isoniazid and rifampin, two of the most powerful first line drugs. ${ }^{6}$ To treat MDR Tb, healthcare providers use a combination of secondline drugs, which may have more side effects. Such a treatment is longer and costs up to 100 times more. $^{7}$ XDR Tb occurs when a M. tuberculosis strain is resistant to isoniazid, rifampin, a fluoroquinolone, and at least one of kanamycin, capreomycin, or amikacin. XDR Tb strains may also be resistant to additional drugs, further complicating the treatment.

M. tuberculosis has a thick outer cell wall that plays a critical role in the intrinsic resistance of mycobacteria to antibiotics, chemical injury and the immune response. ${ }^{8}$ As a result, a number of drugs act by inhibiting the biosynthesis of this protective coating. Some of the abundant constituents of in the cell wall include the arabinogalactan (AG) polysaccharides, and the lipophilic mycolic acids. The first line drugs used to treat $\mathrm{Tb}$ are isoniazid, rifampin, pyrazinamide and ethambutol. Isoniazid is a pro-drug, which is activated in mycobacteria, and leads to the inhibition of mycolic acid biosynthesis, thereby resulting in bacterial death (Figure 7.1). ${ }^{4,9}$ Rifampin inhibits mRNA synthesis, ${ }^{9}$ and pyrazinamide, also a prodrug, most likely acts by disrupting the bacterial cell membrane potential. Ethambutol inhibits arabinosyl transferase enzymes ${ }^{10}$ responsible for the biosynthesis of the arabinan polysaccharides that form vital components of the cell wall. ${ }^{9}$ Disruption of the cell wall biosynthesis prevents mycobacterial growth and replication. Some of the more commonly used second line drugs include the fluoroquinolones (e.g. moxifloxacin), streptomycin, kanamycin A, B and C, amikacin and capreomycin. ${ }^{9}$ Most of the drugs in this class are broad-spectrum antibiotics and target enzymes involved in DNA transcription or translation. A summary of key $\mathrm{Tb}$ drugs and their modes of action are presented in Figure 7.1. 


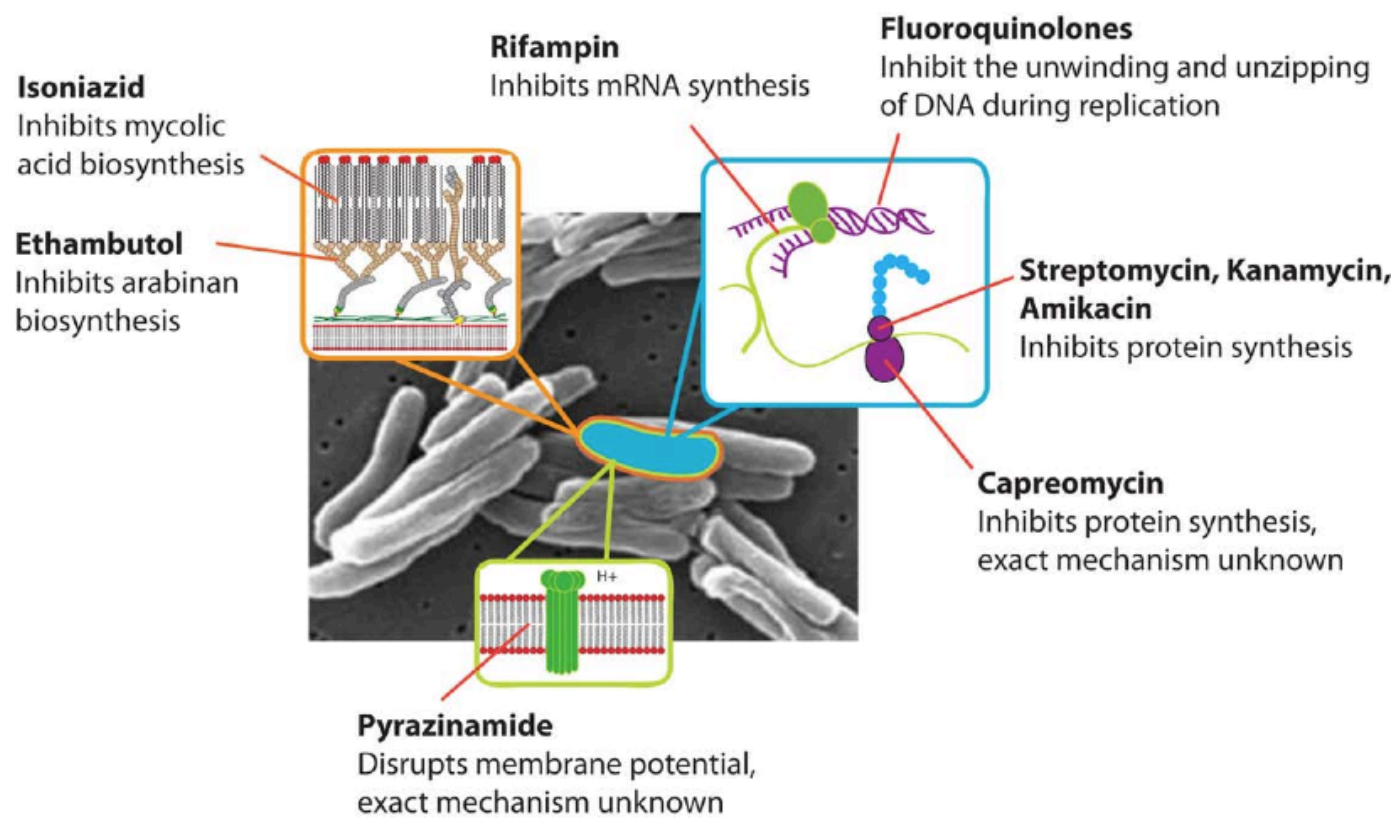

Figure 7.1. Commonly used first and second line $\mathrm{Tb}$ drugs and their mode of action.

In the quest to develop new $\mathrm{Tb}$ drugs we focused our efforts on developing potential drugs that could work by targeting cell wall biosynthesis. As azasugars can inhibit glycosyl transferase enzymes, there is potential that azasugar mimics could be used to inhibit arabinosyl transferase enzymes required for the biosynthesis of the protective M. tuberculosis cell wall. In addition, the alkenylamine precursors have some similarity to ethambutol, a known AraT inhibitor. It is also known that new drugs can be found through screening libraries of compounds, therefore it is also worth testing all azasugar products and synthetic intermediates made so far. Accordingly, the anti-tubercular activity of two target inhibitor series was investigated (Table 7.1). The first was a series of substrate like azasugar transition state mimics, and the second, was a series of ethambutol like inhibitors. 
Table 7.1. Target AraT inhibitor series.

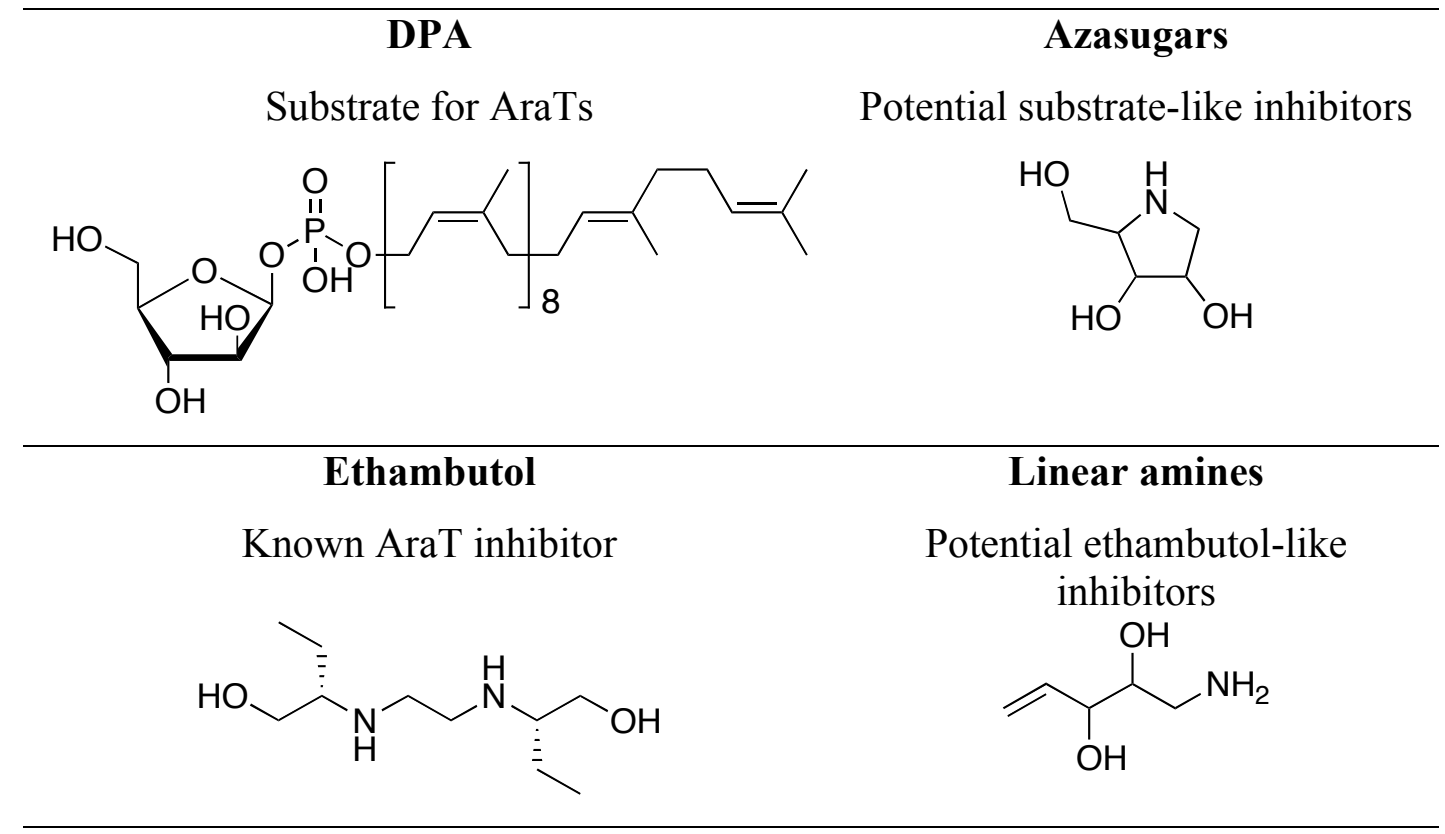

\subsection{Results and Discussion}

\section{Optimisation of the BCG alamar blue assay}

To investigate the potential of our compounds to act as Tb drugs, we needed to develop an assay to screen for anti-tubercular activity. For this we chose to use a Bacillus Calmette-Gérin (BCG) Alamar Blue growth inhibition assay. This robust assay is frequently used in the literature and allows for the rapid and safe screening of anti-tubercular compounds. ${ }^{11-13}$ BCG is a strain of Mycobacterium bovis that has lost its virulence in humans by being cultured in artificial medium for years. Alamar Blue, a redox active dye, is primarily composed of the nonfluorescent compound resazurin (Figure 7.2, blue in colour) which, when reduced, is converted to the pink and highly fluorescent resorufin. Actively dividing cells produce NADPH, which reduces resazurin to resorufin. Therefore, if a compound inhibits BCG growth, the dye will remain blue and very little fluorescence will be observed, however, if no bacterial growth inhibition occurs, the dye will turn pink and fluoresce. 
<smiles>O=c1ccc2[n+]([O-])c3ccc(O)cc3oc-2c1</smiles>

Figure 7.2. Resazurin.

Though the Alamar Blue assay has been widely used in the literature, it needed to be optimised in our laboratory to establish: 1) the initial concentration of bacteria that should be used; 2) the number of days the bacteria should be incubated; and 3) the time (number of hours after the addition of Alamar Blue) that fluorescence should be measured at. A titration experiment was established using a 96 well black clear bottom plate, where the outside wells were filled with PBS and replenished at regular intervals to reduce evaporation. If this was not done, inconsistent assay results were obtained. In rows B through to G (Figure 7.3), two fold dilutions of bacteria were added, starting with a concentration of $1.28 \times 10^{6}$ bacteria $^{*}$ per $\mathrm{mL}, 20 \mu \mathrm{L}$ of Alamar Blue was added to rows $\mathrm{B}$ and $\mathrm{C}$, and the plate was incubated at $37^{\circ} \mathrm{C}$. The fluorescence of rows B and C was read at 19, 24, 26 and 28 hours after the addition of Alamar Blue. On day 4, $20 \mu \mathrm{L}$ of Alamar Blue was added to rows D and E, and the fluorescence of these rows read at 17, 19, 24 and 26 hours after Alamar Blue addition. Finally, on day 7, Alamar Blue was added to rows $F$ and $G$ and the fluorescence of these rows read at 2, 18, 23 and 26 hours post addition (Figure 7.4).

\footnotetext{
* M. bovis BCG Pasteur strain $1173 \mathrm{P}_{2}$ was gifted by AgResearch Wallaceville Animal Research Centre, Upper Hutt, New Zealand.
} 


\section{Decreasing Bacteria Concentration}

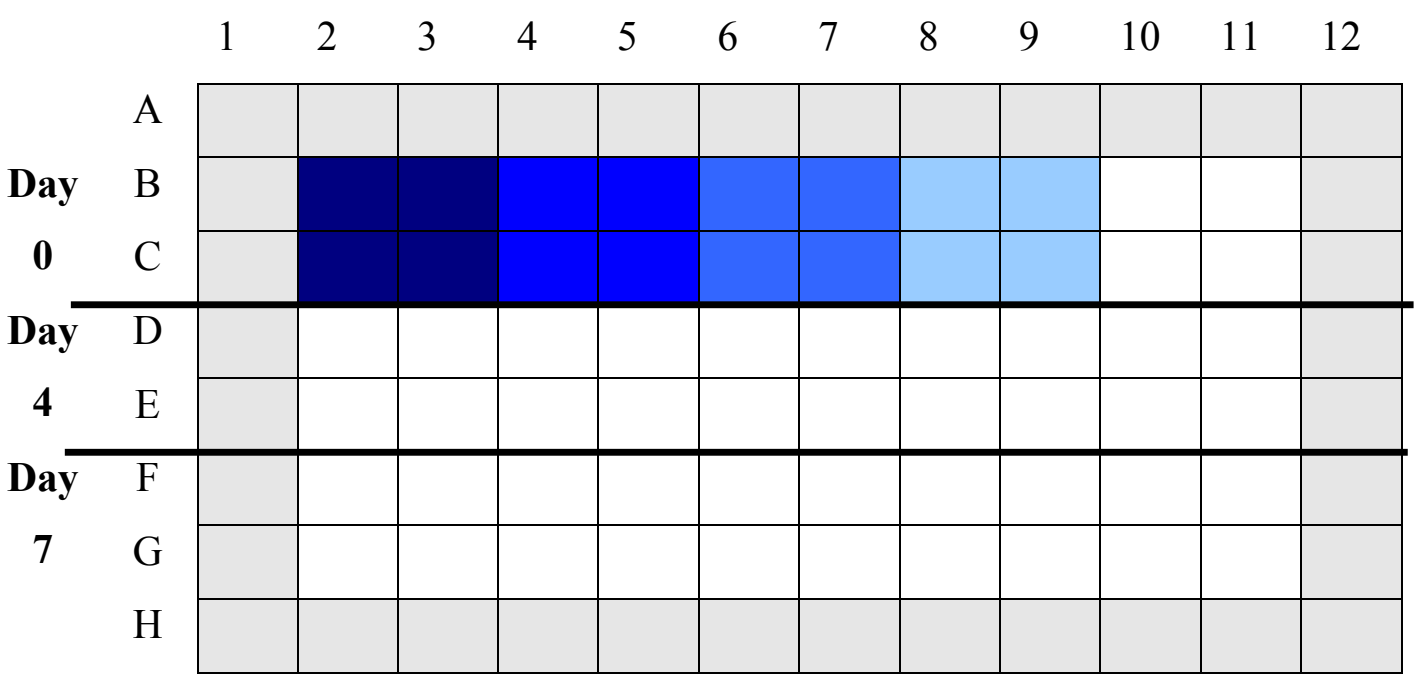

Figure 7.3. Diagram of plate used for $B C G$ assay. Bacteria were added to the plate in two fold dilutions (from $1.28 \times 10^{6}$ per $\mathrm{mL}$, going down to $5.0 \times 10^{3}$ bacteria per $\mathrm{mL})$.

Titration curves were then plotted to determine the optimal initial concentration of $\mathrm{BCG}$, the length of incubation, and the time at which fluorescence should be read (Figure 7.4). From these results, we can see that reading the fluorescence 2 hours post Alamar Blue addition (day 7, hour 2) gives inconsistent results, and a titration curve is not observed. Between 17 and 26 hours post the addition of Alamar blue, the fluorescence readings are more consistent (days 0, 4 and 7). Therefore, fluorescence was measured at 24 hours post Alamar blue addition in subsequent experiments, as this was a convenient time point. To determine the initial concentration of bacteria and optimal incubation period required, we investigated initial concentrations of bacteria that gave very little fluorescence at day 0 , and maximum fluorescence after 4 or 7 days. From the titration curve it can be observed that an initial concentration of bacteria of $40,000 / \mathrm{mL}$, gave a fluorescence reading close to zero on day 0 . By day 7 these bacteria had grown to such an extent that they produced approximately maximal fluorescence. This point on the graph gave the greatest difference between fluorescence on day 0 and fluorescence on day 7. Therefore, an initial bacteria concentration of 40,000 bacteria per $\mathrm{mL}$ and an incubation time of 7 days was determined optimum for all subsequent assays. 


\section{Titration of BCG bacteria}

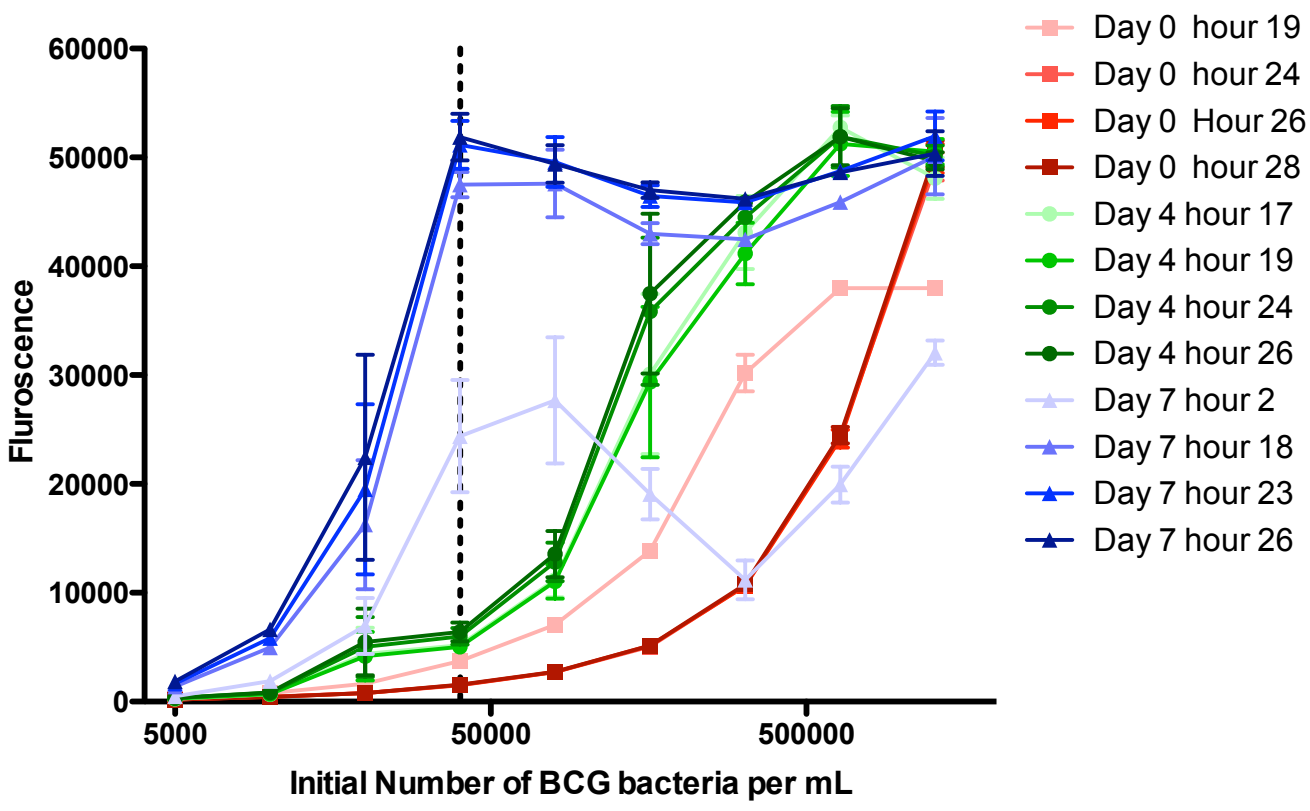

Figure 7.4. BCG titration curve. Each bacterial concentration was repeated twice, error bars represent SE.

These experimental conditions were then assessed by conducting an ethambutol titration. Two fold dilutions of ethambutol, in triplicate, were incubated for 7 days with 8,000 bacteria per well $(40,000$ bacteria per $\mathrm{mL})$. The results from this experiment were plotted and a dose response curve obtained (Figure 7.5). The minimum inhibitory concentration (MIC) was determined to be $29 \mu \mathrm{M}$. In the literature the MIC of ethambutol against M. tuberculosis (H37Rv) in vitro was reported as $2 \mu \mathrm{M},{ }^{9}$ however, the MIC against a BCG strain has been reported as $7 \mu \mathrm{M}^{14}$ The MIC obtained using this alamar blue assay is, therefore, comparable to literature. 


\section{Ethambutol titration}

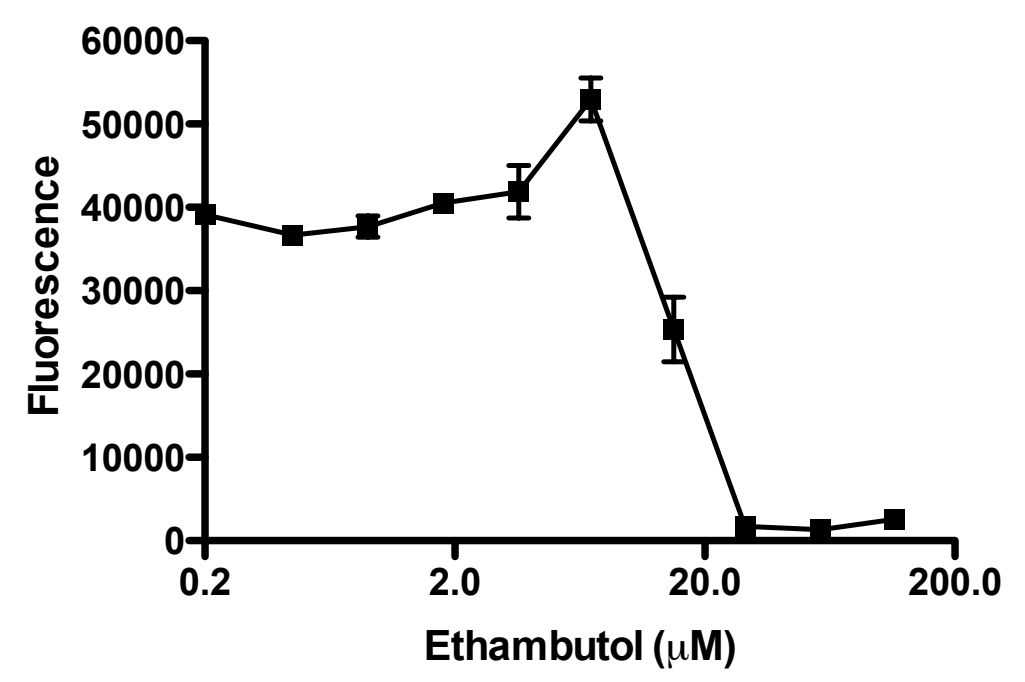

Figure 7.5. Ethambutol Titration. Each concentration was repeated in triplicate, error bars represent SE.

\section{Testing azasugars and linear alkenylamines}

Having established the optimal conditions for the BCG Alamar Blue assay, a series of azasugars (1 to 8, Table 7.2) and linear alkenylamines (10 to $\mathbf{1 5}$ ) were tested for their ability to inhibit the growth of BCG. Each compound was tested at six concentrations, in two fold dilutions beginning at $500 \mu \mathrm{g} / \mathrm{mL}$, and each of these series was repeated in triplicate. On each plate two negative controls (PBS only and the compounds being tested in PBS only) and a positive control (bacteria in PBS only) and an ethambutol titration control (115 to $4 \mu \mathrm{M})$ were included. A photograph of the Alamar Blue BCG assay in which alkenylamine 14 was tested is given (Figure 7.6). This illustrates the colour change of the blue resazurin to the pink resorufin resulting from bacterial production of NADPH. Unfortunately, cyclic carbamates $\mathbf{1}$ to $\mathbf{4}$ and azasugars $\mathbf{5}$ to $\mathbf{8}$ did not demonstrate any inhibitory activity (MIC >3.5 mM). (Diphenylmethyl)amine (9) demonstrated modest activity with an MIC between $1.36-2.73 \mathrm{mM}$. Alkenylamines 10 to $\mathbf{1 3}$ did not demonstrate any inhibitory activity, however, (diphenylmethyl)amine functionalised alkenylamine 14 (Figure 7.6) and the methylated derivative 15 demonstrated modest activity, inhibiting bacterial growth at $0.44-0.88 \mathrm{mM}$ and 
$0.80-1.61 \mathrm{mM}$, respectively (Table 7.2). This inhibitory activity was greater than that observed with (diphenylmethyl)amine (9) alone $(1.36-2.73 \mathrm{mM})$.

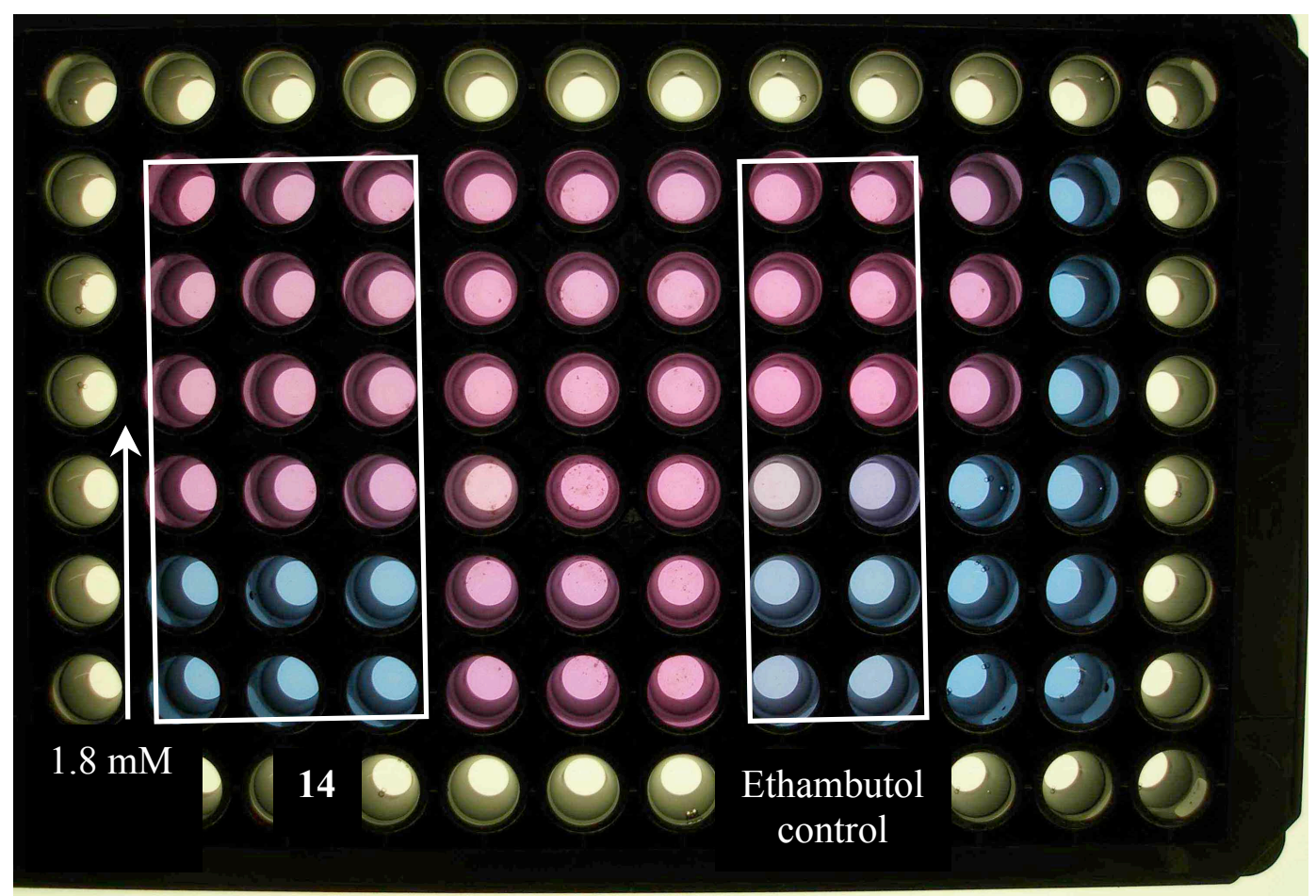

Figure 7.6. Photograph of BCG Alamar Blue assay demonstrating the inhibitory activity of $\mathbf{1 4}$ in two fold dilutions, beginning at $1.8 \mathrm{mM}$, repeated in triplicate. 
Table 7.2. Compounds tested in the BCG Alamar Blue assay and their MIC values.

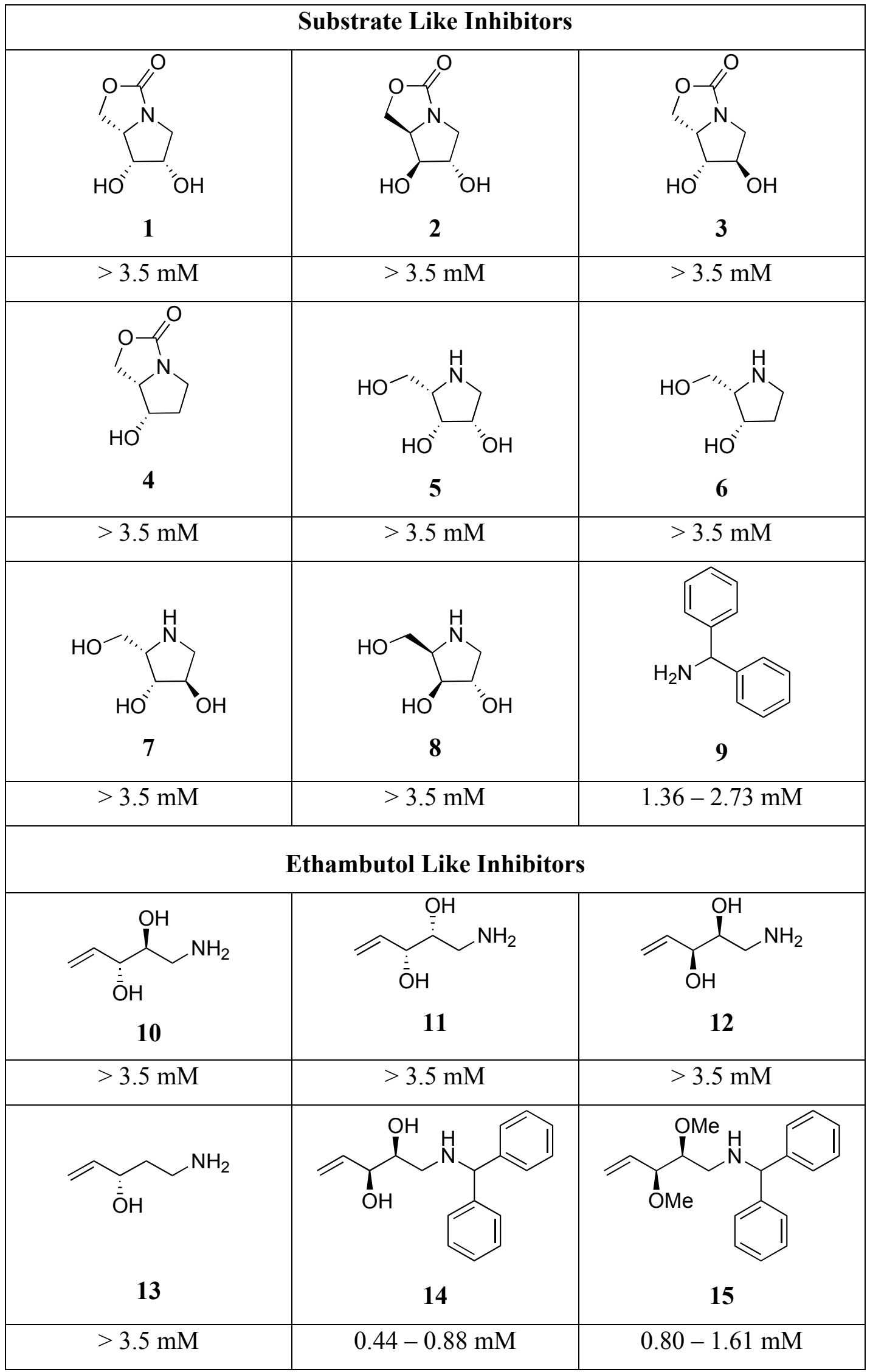


The lack of activity observed for the unprotected azasugars (1 to 8) and alkenylamines (10 to 13, Table 7.1) may be due to the hydrophilicity of the compounds, making it difficult for them to travel through the high lipid content of the bacterial cell wall. Compounds with a hydrophobic moiety, such as alkenylamines 14 and $\mathbf{1 5}$, may more readily pass through this waxy coating to penetrate the cell and inhibit growth. Given this, the addition of a lipid tail to the azasugar scaffold is a potentially interesting avenue for further research.

The activity of $\mathbf{1 4}$ could, in turn, potentially be improved by altering the lipophilic group present on the amine. In the future, a library of alkenylamines with different stereochemistry and various lipids could be synthesised and screened for BCG inhibition. It would also be valuable to investigate the activity of these compounds toward other tuberculosis strains (e.g. M. smegmatis, and M. tuberculosis) and test their specificity by investigating their ability to inhibit the growth of other bacteria (e.g. Escherichia coli or Staphylococcus aureus). The toxicity of the compounds toward human cells should also be investigated as well as their ability to inhibit the growth of dormant mycobacteria found in macrophages. 


\subsection{Experimental}

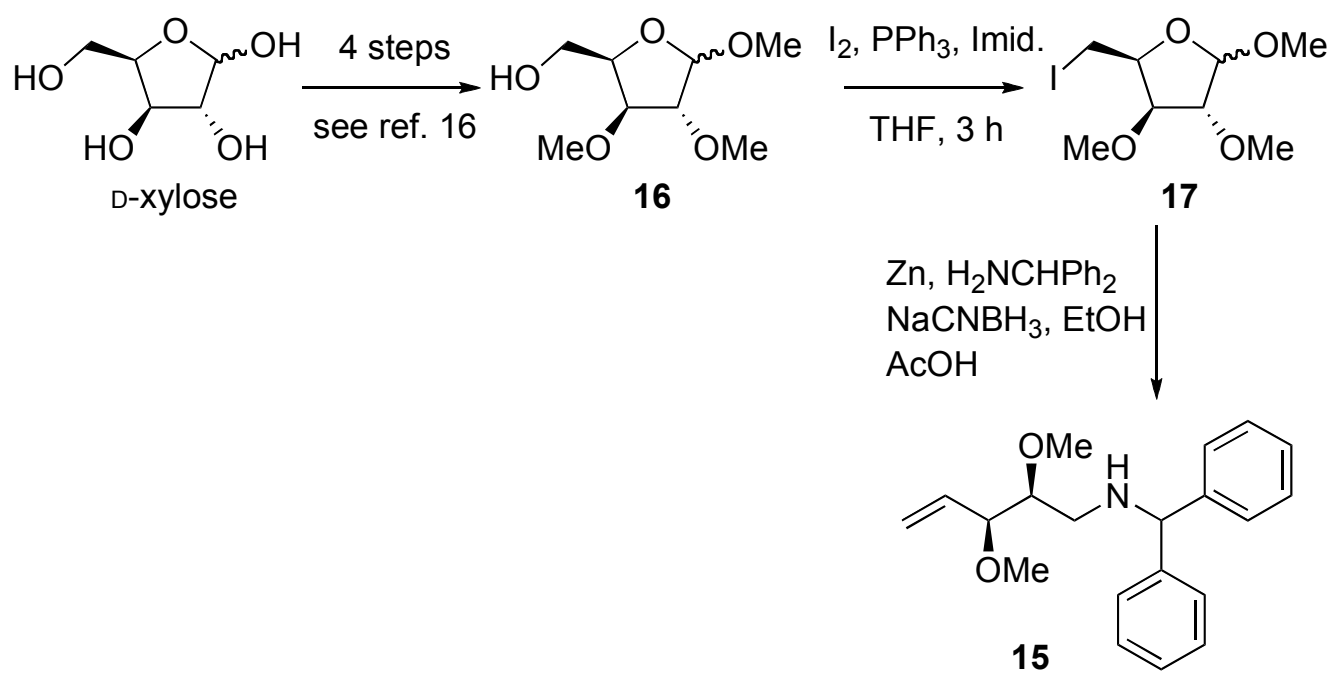

Scheme 7.1. Synthesis of methylated alkenylamine 15.<smiles>CO[C@H]1OC(CO)[C@H](OC)[C@H]1OC</smiles>

OMe Methyl 2,3-di- $O$-methyl- $\alpha / \beta$-D-xylofuranoside

(16).

Synthesised in four steps from D-xylose. Data matched that previously reported. ${ }^{15}$<smiles>CO[C@H]1O[C@H](CI)[C@@H](OC)[C@@H]1OC</smiles>

Methyl 5-deoxy-2,3-di- $O$-methyl-5-iodo- $\alpha / \beta-D-$

xylofuranoside (17). To a solution of $16(301 \mathrm{mg}, 1.57 \mathrm{mmol})$ in THF (20 mL) was added $\mathrm{PPh}_{3}(616 \mathrm{mg}, 2.35 \mathrm{mmol})$, and imidazole $(214 \mathrm{mg}, 3.14 \mathrm{mmol})$ and the resulting mixture stirred at reflux for $3 \mathrm{~h}$, then cooled filtered and concentrated in vacuo. The crude reaction mixture was purified by silica gel flash column chromatography (Petroleum Ether/EtOAc, 5/1, v/v) to give 17 as a colourless oil (160 mg, $0.53 \mathrm{mmol}, 34 \%) . \mathrm{R}_{f}=0.71$ (EtOAc); ${ }^{1} \mathrm{H}$ NMR $\left(500 \mathrm{MHz}, \mathrm{CDCl}_{3}\right) \delta$

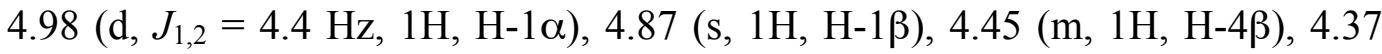
$\left(\mathrm{td}, J_{3,4}=J_{4,5 \mathrm{a}}=6.2, J_{4,5 \mathrm{~b}}=7.3 \mathrm{~Hz}, 1 \mathrm{H}, \mathrm{H}-4 \alpha\right), 3.86\left(\mathrm{dd}, J_{2,3}=5.4, J_{3,4}=6.2 \mathrm{~Hz}\right.$, $1 \mathrm{H}, \mathrm{H}-3 \alpha), 3.77$ (dd, $\left.J_{1,2}=4.4, J_{2,3}=5.4 \mathrm{~Hz}, 1 \mathrm{H}, \mathrm{H}-2 \alpha\right), 3.74-3.73(\mathrm{~m}, 2 \mathrm{H}, \mathrm{H}-2 \beta$ and $\mathrm{H}-3 \beta), 3.43$ (s, 3H, OMe), 3.41 (s, 3H, OMe), $3.36\left(\mathrm{dd}, J_{4,5 \mathrm{a}}=7.3, J_{5 \mathrm{a}, 5 \mathrm{~b}}=9.7\right.$ $\mathrm{Hz}, 1 \mathrm{H}, \mathrm{H}-5 \mathrm{a} \beta), 3.31\left(\mathrm{dd}, J_{4,5 \mathrm{a}}=6.2, J_{5 \mathrm{a}, 5 \mathrm{~b}}=10.1 \mathrm{~Hz}, 1 \mathrm{H}, \mathrm{H}-5 \mathrm{a} \alpha\right), 3.27\left(\mathrm{dd}, J_{4,5 \mathrm{~b}}\right.$ $\left.=7.5, J_{5 \mathrm{a}, 5 \mathrm{~b}}=9.7 \mathrm{~Hz}, 1 \mathrm{H}, \mathrm{H}-5 \mathrm{~b} \beta\right), 3.16\left(\mathrm{dd}, \mathrm{J}_{4,5 \mathrm{~b}}=7.3, \mathrm{~J}_{5 \mathrm{a}, 5 \mathrm{~b}}=10.1 \mathrm{~Hz}, 1 \mathrm{H}, \mathrm{H}-\right.$ $5 \mathrm{~b} \alpha) ;{ }^{13} \mathrm{C}$ NMR $\left(125 \mathrm{MHz}, \mathrm{CDCl}_{3}\right) \delta 108.0(\mathrm{C} 1 \beta), 100.8(\mathrm{C} 1 \alpha), 88.1(\mathrm{C} 2 \beta), 85.9$ 


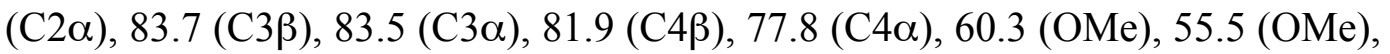
$3.6(\mathrm{C} 5 \beta), 2.4(\mathrm{C} 5 \alpha)$; HRMS(ESI) $m / z$ calcd. for $\left[\mathrm{C}_{8} \mathrm{H}_{15} \mathrm{O}_{4} \mathrm{I}+\mathrm{Na}\right]^{+}: 324.9907$, obsd.: 324.9915 .<smiles>C=CC(OC)C(CNC(c1ccccc1)c1ccccc1)OC</smiles>

(2S,3S)-1-(Diphenylmethyl)amino-2,3-di-O-methyl-

pent-4-ene-2,3-diol (15). To a solution of methyl iodosugar 17 (144 mg, $0.48 \mathrm{mmol})$ in $\mathrm{EtOH} / \mathrm{H}_{2} \mathrm{O}(15 \mathrm{~mL} / 0.3 \mathrm{~mL})$ was added activated $\mathrm{Zn}(125 \mathrm{mg}, 1.91$ mmol), aminodiphenylmethane (288 $\mu \mathrm{L}, 307 \mathrm{mg}, 1.67 \mathrm{mmol}), \mathrm{NaCNBH}_{3}(102$ $\mathrm{mg}, 0.96 \mathrm{mmol})$, and $\mathrm{AcOH}(50 \mu \mathrm{L})$ and the solution was stirred at reflux for 18 h. The reaction mixture was cooled, and dry loaded onto a silica gel by the addition of silica gel to the dissolved material followed by evaporation of the solvent under reduced pressure. The silica gel was loaded onto a silica gel column for purification by flash column chromatography (Petroleum ether/EtOAc, 10/1, $\mathrm{v} / \mathrm{v})$ to give alkenylamine 15 as a colourless oil $(119 \mathrm{mg}, 0.80 \mathrm{mmol}, 80 \%) . \mathrm{R}_{f}=$ $0.53\left(\right.$ EtOAc); $[\alpha]_{\mathrm{D}}{ }^{17}=-10.0\left(c=1.0, \mathrm{CHCl}_{3}\right) ;{ }^{1} \mathrm{H}$ NMR $\left(500 \mathrm{MHz}, \mathrm{CDCl}_{3}\right) \delta$ $7.34-7.10(\mathrm{~m}, 10 \mathrm{H}$, aromatics $), 5.68\left(\mathrm{ddd}, J_{3,4}=7.7, J_{4,5 \text {-cis }}=10.4, J_{4,5 \text {-trans }}=\right.$ $17.3 \mathrm{~Hz}, 1 \mathrm{H}, \mathrm{H}-4), 5.29\left(\mathrm{~d}, J_{4,5-\text { trans }}=17.3 \mathrm{~Hz}, 1 \mathrm{H}, \mathrm{H}-5\right.$ trans $), 5.25\left(\mathrm{~d}, J_{4,5-\text { cis }}=\right.$ $10.4 \mathrm{~Hz}, 1 \mathrm{H}, \mathrm{H}-5$ cis), 4.78 (s, 1H, C$\left.-\mathrm{Ph}_{2}\right), 3.77$ (dd, $J_{2,3}=5.9, J_{3,4}=7.7 \mathrm{~Hz}, 1 \mathrm{H}$, H-3), 3.47 (s, 3H, OMe), 3.39 (ddd, $\left.J_{1 \mathrm{a}, 2}=4.1, J_{2,3}=5.9, J_{1 \mathrm{~b}, 2}=6.8 \mathrm{~Hz}, 1 \mathrm{H}, \mathrm{H}-2\right)$, $3.30(\mathrm{~s}, 3 \mathrm{H}, \mathrm{OMe}), 2.74\left(\mathrm{dd}, J_{1 \mathrm{a}, 2}=4.1, J_{1 \mathrm{a}, 1 \mathrm{~b}}=12.3 \mathrm{~Hz}, 1 \mathrm{H}, \mathrm{H}-1 \mathrm{a}\right), 2.60\left(\mathrm{dd}, J_{1 \mathrm{~b}, 2}\right.$ $\left.=6.8, J_{1 \mathrm{a}, 1 \mathrm{~b}}=12.3 \mathrm{~Hz}, 1 \mathrm{H}, \mathrm{H}-1 \mathrm{~b}\right) ;{ }^{13} \mathrm{C} \mathrm{NMR}\left(125 \mathrm{MHz}, \mathrm{CDCl}_{3}\right) \delta 144.2,143.8$ (aromatics), 134.9 (C4), 128.5, 128.4, 127.6, 127.4, 127.3, 127.0, 126.9, (aromatics), 118.8 (C5), 83.8 (C3), 82.7 (C2), 67.7 ( $\left.\underline{\mathrm{CH}}-\mathrm{Ph}_{2}\right), 58.9$ (OMe), 56.7 (OMe), 47.9 (C1); HRMS(ESI) $m / z$ calcd. for $\left[\mathrm{C}_{20} \mathrm{H}_{25} \mathrm{NO}_{2}+\mathrm{H}\right]^{+}: 312.1958$, obsd.: 312.1959 .

\section{Growing BCG stock}

\section{Preparation of Tween albumin broth (TAB)}

$1.3 \mathrm{~g}$ Dubos Broth Base was dissolved (Difco, Detroit, Michigan, USA) in 180 $\mathrm{mL}$ deionised $\mathrm{H}_{2} \mathrm{O}$ in a schott bottle $(200 \mathrm{ml})$. The solution was then sterilised by autoclaving, the solution was cooled to below $50^{\circ} \mathrm{C}$ and $20 \mathrm{~mL}$ oleic albumin 
dextrose catalase (OADC) growth supplement (Difco) ${ }^{*}$ was added. Note that if OADC is added when the media is too hot, the proteins will denature. Though the enrichment (OACD) comes "free from contaminating microorganisms" it was also filtered before use as an added precaution (using a $0.2 \mu \mathrm{m}$ filter). $10 \mathrm{~mL}$ volumes of the prepared TAB were dispensed into $50 \mathrm{~mL}$ tissue culture flasks (Falcon ${ }^{\circledR}$, Becton Dickinson Labware).

\section{Growing BCG}

One vial of frozen BCG Pasteur 1173P2 stock was defrosted.* The defrosted BCG were inoculated into a $50 \mathrm{~mL}$ Falcon tube with $10 \mathrm{~mL}$ TAB. The flask was incubated at $37{ }^{\circ} \mathrm{C}$ until log phase growth was reached (takes up to 7 days - judge by eye looking for increased turbidity). Five $\mathrm{mL}$ of this media was removed to replace stock BCG vial. The remaining $5 \mathrm{~mL}$ was made up to a volume of $40 \mathrm{~mL}$ using TAB. Once this flask reached log phase growth, it was split into 4 times 10 $\mathrm{mL}$ batches, put into 4 times $75 \mathrm{~cm}^{3}$ flasks and each flask made up to $100 \mathrm{~mL}$ total volume using TAB. Once these flasks had reached log phase growth, they were each split in half, to give 8 times $50 \mathrm{~mL}$ flasks, and each was made up to 250 $\mathrm{mL}$ total volume using $\mathrm{TAB}$. The $\mathrm{BCG}$ were harvested into $50 \mathrm{~mL}$ (or larger) Falcon tubes, and centrifuged for 30 minutes at $3115 \mathrm{~g}, 4{ }^{\circ} \mathrm{C}$. The BCG were washed twice in sterile PBS ( $\mathrm{pH}$ 7.4) containing $0.05 \%$ Tween 80 (Polyoxyethylene sorbitol monooleate, Sigma). Finally, the BCG were suspended in $10-15 \mathrm{~mL}$ of sterile PBS containing $0.05 \%$ Tween 80 (Polyoxyethylene sorbitol monooleate, Sigma) and vortexed (in hood) vigorously. Aliquots from $0.25 \mathrm{~mL}$ to $1 \mathrm{~mL}$ were prepared in $1.8 \mathrm{~mL}$ Cryotubes $^{\mathrm{TM}}$ (Nalge Nunc), and kept frozen at -70 ${ }^{\circ} \mathrm{C}$ until use.

To enumerate viable BCG, a one in ten fold serial dilution of sample aliquots was prepared (from 1 to $10^{-6}$ ). A Middlebrook $7 \mathrm{H} 11$ agar ${ }^{*}$ with 10\% OADC enrichment was divided into six sections, and onto one section 3 times $10 \mu \mathrm{L}$ of

\footnotetext{
* Difco, Fort Richard Laboratories, Auckland, NZ.

${ }^{* *}$ M. bovis BCG Pasteur strain $1173 \mathrm{P}_{2}$ was gifted by AgResearch Wallaceville Animal Research Centre, Upper Hutt, New Zealand.
} 
the $1 \times 10^{-1}$ serial dilution was dropped. This was repeated for the remaining concentrations (from $1 \times 10^{-2}$ to $1 \times 10^{-6}$ ) and the agar was incubated at $37^{\circ} \mathrm{C}$ for 21 days, then the colonies were counted. To confirm that the batch of BCG was free from contaminating micro-organisms, $100 \mu \mathrm{l}$ of the BCG aliquot was incubated at $37^{\circ} \mathrm{C}$ for 5 days (if it is sterile, nothing should grow).

\section{BCG alamar blue assay}

Samples: Compounds were dissolved in sterile PBS (sterile DMSO was added if necessary - up to $5 \%$ ) to make solutions of $1 \mathrm{mg} / \mathrm{mL}$. The samples were then filtered (Acrodisc $13 \mathrm{~mm}$ syringe filter, with $0.22 \mu \mathrm{m}$ pore size).

BCG: BCG were defrosted, then sonicated for 10 seconds, and placed on ice for 10 seconds, this was repeated twice. Stock BCG solutions were made to $8 \times 10^{4}$ bacteria/mL using sterile TAB ( $\mathrm{pH} 6.6)$ to suspend.

Assay: In a black clear bottom 96 well plate, two fold serial dilutions of each compound in triplicate were added, in volumes of $100 \mu \mathrm{L}$, all outer wells were left unused. An ethambutol titration (two fold dilutions from 115 to $4 \mu \mathrm{M}$ ) was included as a positive control, as well as a positive BCG only control in triplicate, and two negative controls (media only and media and compound only) also in triplicate. $100 \mu \mathrm{L}$ of BCG stock was added to the appropriate wells and all the other wells were made up to $200 \mu \mathrm{L}$ using sterile PBS. $200 \mu \mathrm{L}$ PBS was added to the outer wells. The plate was then incubated at $37{ }^{\circ} \mathrm{C}, 5 \% \mathrm{CO}_{2}$ for 7 days (day of set up was day 0), the outer wells were filled over the incubation period. On day 7, $20 \mu \mathrm{L}$ of Alamar Blue (Invitrogen) was added to all the test wells and the plate was incubated a further $24 \mathrm{~h}$. Fluorescence was read using a FLUOstar optima plate reader with an excitation filter of $544 \mathrm{~nm}$, and an emission filter of $590 \mathrm{~nm}$. Fluorescence values were determined by subtracting the fluorescence of the negative control wells from the fluorescence of the test wells. 


\subsection{References}

(1) Hernandez, C.; Cetner, A. S.; Jordan, J. E.; Puangsuvan, S. N.;

Robinson, J. K. J. Am. Acad. Dermatol. 2008, 59, 363-380.

(2) ESR "Monthly Notifiable Disease Surveillance Report," 2008.

(3) Centers for Disease Control and Prevention Morb. Mortal. Wkly Rep. 2006, 55, 301-328.

(4) Vilchèze, C.; Jacobs Jr, W. R. Annu. Rev. Microbiol. 2007, 61, 35- 50.

(5) David, H. L. Appl. Microbiol. 1970, 20, 810-814.

(6) Palomino, J. C.; Leão, S. C.; Ritacco, V. Tuberculosis 2007 From basic science to patient care; TuberculosisTextbook.com, 2007.

(7) Jasmer, R. M.; Snyder, D. C.; Saukkonen, J. J.; Hopewell, P. C.; Bernardo, J.; King, M. D.; Kawamura, L. M.; Daley, C. L. Clin. Infect. Dis. 2004, 38, 363-369.

(8) Bhowruth, V.; Alderwick, L. J.; Brown, A. K.; Bhatt, A.; Besra, G. S. Biochem. Soc. Trans 2008, 36, 555-565.

(9) Brennan, P. J.; Young, D. B. Tuberculosis 2008, 88, 1-169.

(10) Alderwick, L. J.; Seidel, M.; Sahm, H.; Besra, G. S.; Eggeling, L. J. Biol. Chem. 2006, 281, 15653-15661.

(11) Taneja, N. K.; Tyagi, J. S. J. Antimicrob. Chemother. 2007, 60, 288-293.

(12) Yajko, D. M.; Madej, J. J.; Lancaster, M. V.; Sanders, C. A.; Cawthon, V. L.; Gee, B.; Babst, A.; Hadley, W. K. J. Clin. Microbiol. 1995, 33, 23242327.

(13) Baker, C. N.; Banerjee, S. N.; Tenover, F. C. J. Clin. Microbiol. 1994, 32, 1261-1267.

(14) Shawar, R. M.; Humble, D. J.; Van Dalfsen, J. M.; Stover, C. K.; Hickey, M. J.; Steele, S.; Mitscher, L. A.; Baker, W. Antimicrob. Agents Chemother. 1997, 41, 570-574.

(15) Kováč, P.; Petriková, M. Carbohydr. Res. 1971, 19, 249-251. 


\section{Global Conclusions and Future Prospects}

The findings from the work reported in this thesis can be divided into two sections. In the first section, two $\alpha$-GalCer glycolipid analogues were synthesised in order to investigate the importance of the 4-hydroxyl for iNKT cell activation. Here I found that the activity of the two 4-deoxy $\alpha$-GalCer analogues was species-specific. The 4-deoxy $\alpha$-GalCer sphinganine and sphingosine analogues demonstrated comparable activity to $\alpha$-GalCer in mice. Toward human iNKT cells, however, the 4-deoxy analogues demonstrated significantly reduced iNKT cell activity. The reduced activity is attributed to species-specific differences in iNKT cell glycolipid recognition rather than reduced CD1d presentation. From these results we suggest that glycolipids developed for potent CD1d-iNKT cell activity in humans should contain a ceramide base with the 4-hydroxyl present.

A number of $\alpha$-GalCer analogues with modifications to the lipid portion have been synthesised to investigate the structural requirements for CD1d binding and iNKT cell activation. However, only a few studies have focused on modifications to the carbohydrate head group. In the future it would be valuable to investigate the ability of glycolipids with additional carbohydrate groups to bind to CD1d and activate iNKT cells. The majority of the carbohydrate-modified glycolipids that have been investigated for activity often possess the 4-deoxy sphingosine lipid, e.g. iGb3. Therefore, it would be valuable to investigate the activity of carbohydrate modified glycolipid analogues containing the phytosphingosine lipid base.

The second section of this thesis focused on developing protecting group free methodology for the synthesis of azasugars. In this work two new reaction 
methodologies were discovered. These facilitated the protecting group free synthesis of five membered azasugars. The first reaction allowed for the synthesis of primary amines directly from aldehydes. The most important factors leading to the chemoselective synthesis of primary amines were a $\mathrm{pH}$ of approximately 12 , a large excess of ammonia, and an aldehyde concentration of $20 \mathrm{~mL}$ of ethanol per mmol. Overall, the reductive amination methodology was applicable to a wide range of functionalised substrates. The second reaction was a carbamate annulation for the stereoselective synthesis of cyclic carbamates from olefinic amines. Overall, this carbamate annulation methodology shows great potential for the synthesis of five membered azasugars. However, competition between the formation of five and six membered cyclisation products can limit the scope of the methodology for the synthesis of six membered azasugars. Our two new synthetic methodologies are important additions to the chemist's toolbox and we believe that both methodologies will find wide application in the synthesis of azasugars and other organic molecules without using protecting groups.

In the future it would be valuable to investigate the ability for these azasugars to inhibit glycosidase and glycosyl transferase enzymes. If specific inhibitory activity is observed the active azasugar(s) could be developed to treat a specific disease. In addition lead compounds could be modified by the addition of lipophilic moieties, this could lead to improved inhibitory activity. The protecting group free methodology could also be expanded by developing additional reactions that can be conducted in water without the use of protecting groups. Specifically, the development of a carbon-carbon bond forming reaction that could be performed without the use of protecting groups would be a valuable addition to the methodology developed in this thesis. This would enable additional classes of molecules to be accessed via protecting group free methodology. 


\section{Appendix - NMR Spectra}

Chapter 2: Spectra of final glycolipids

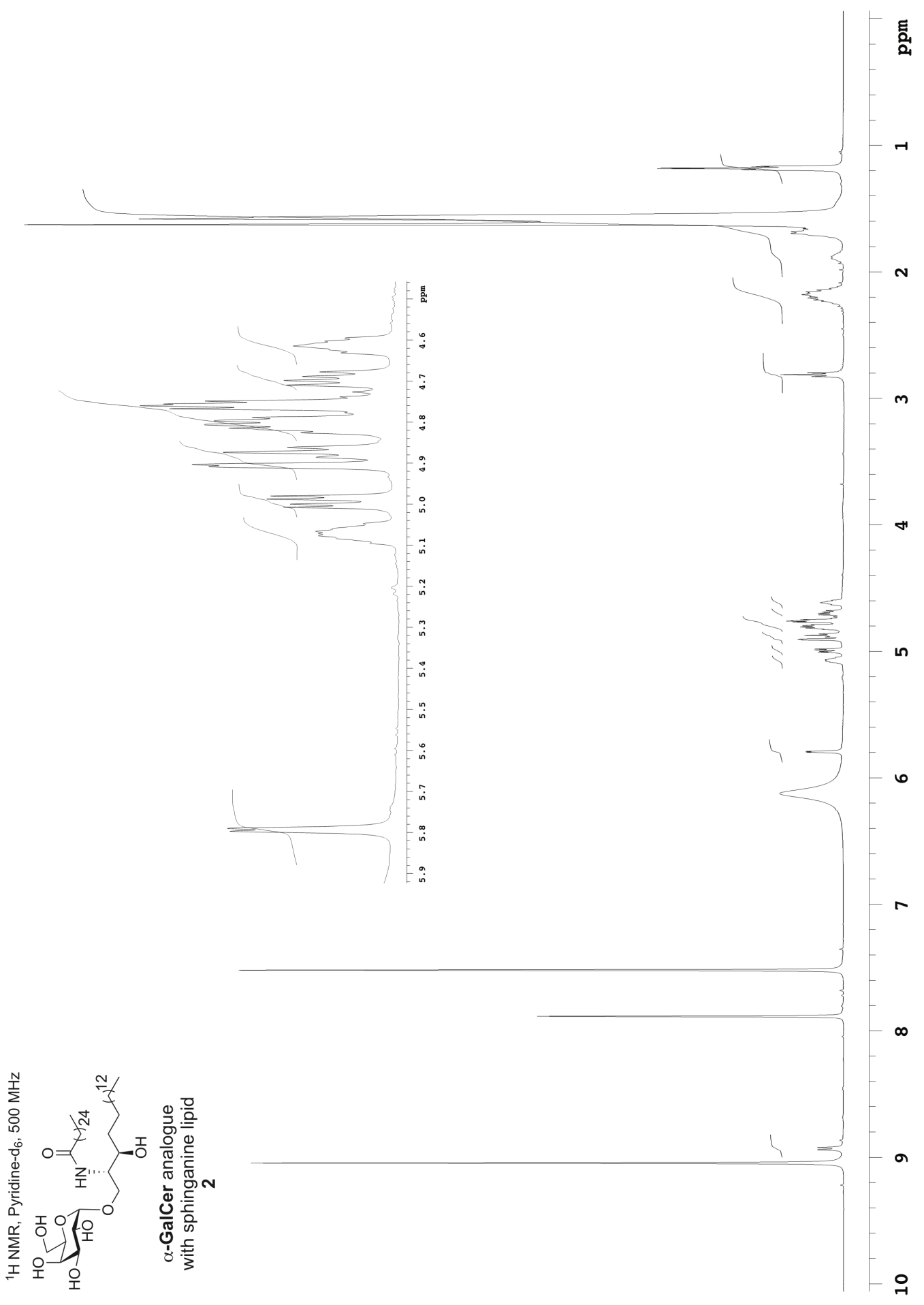




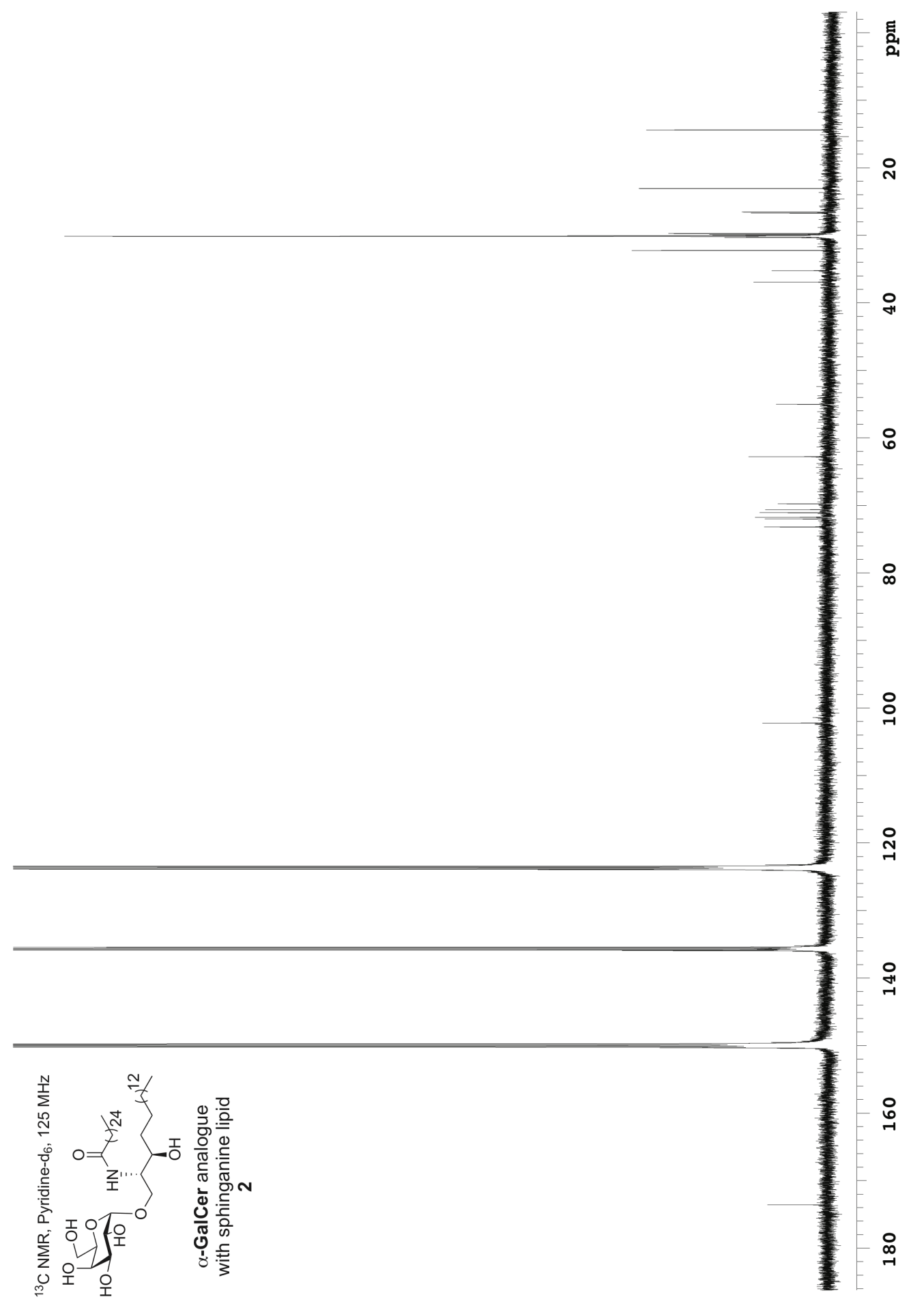




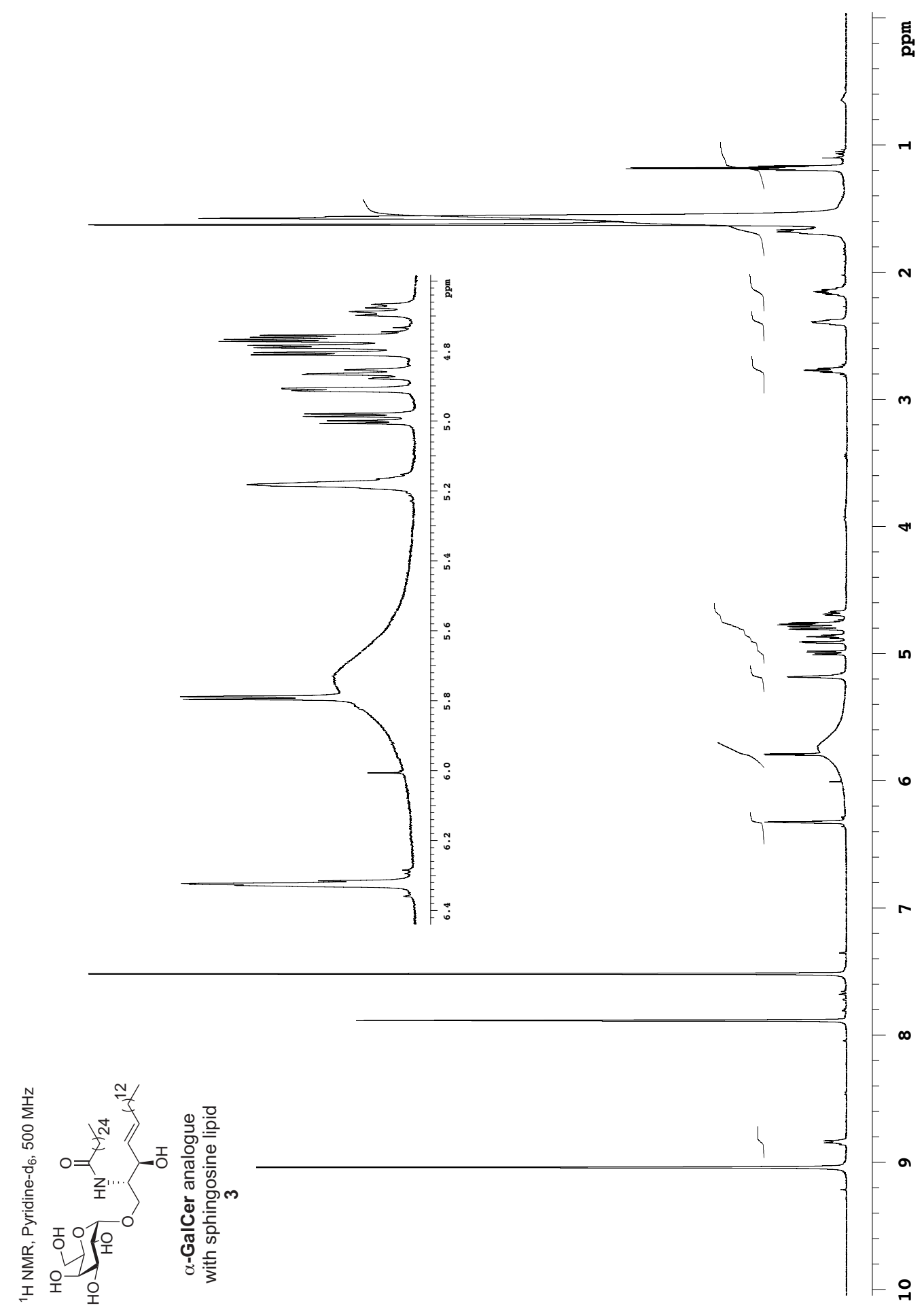




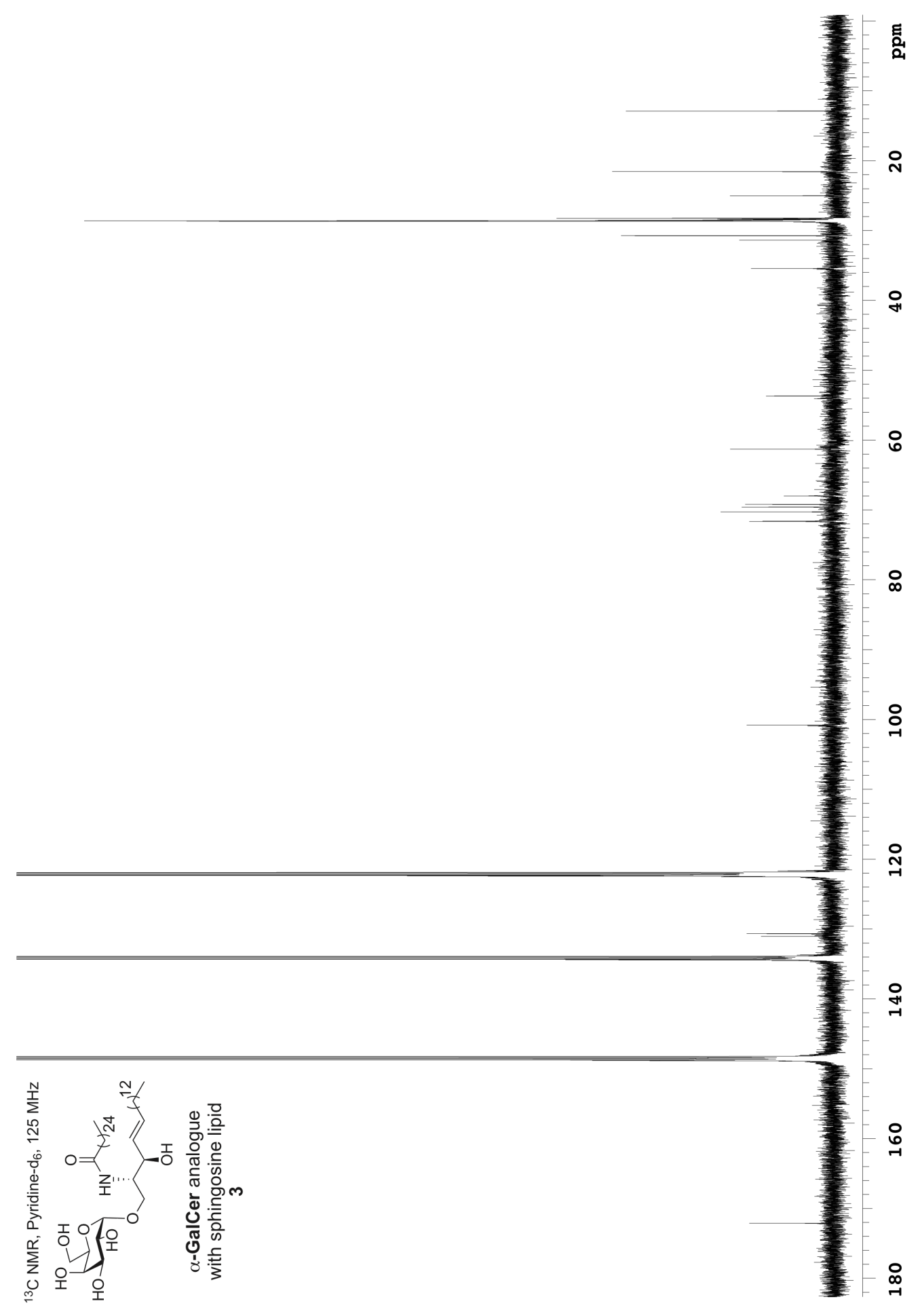




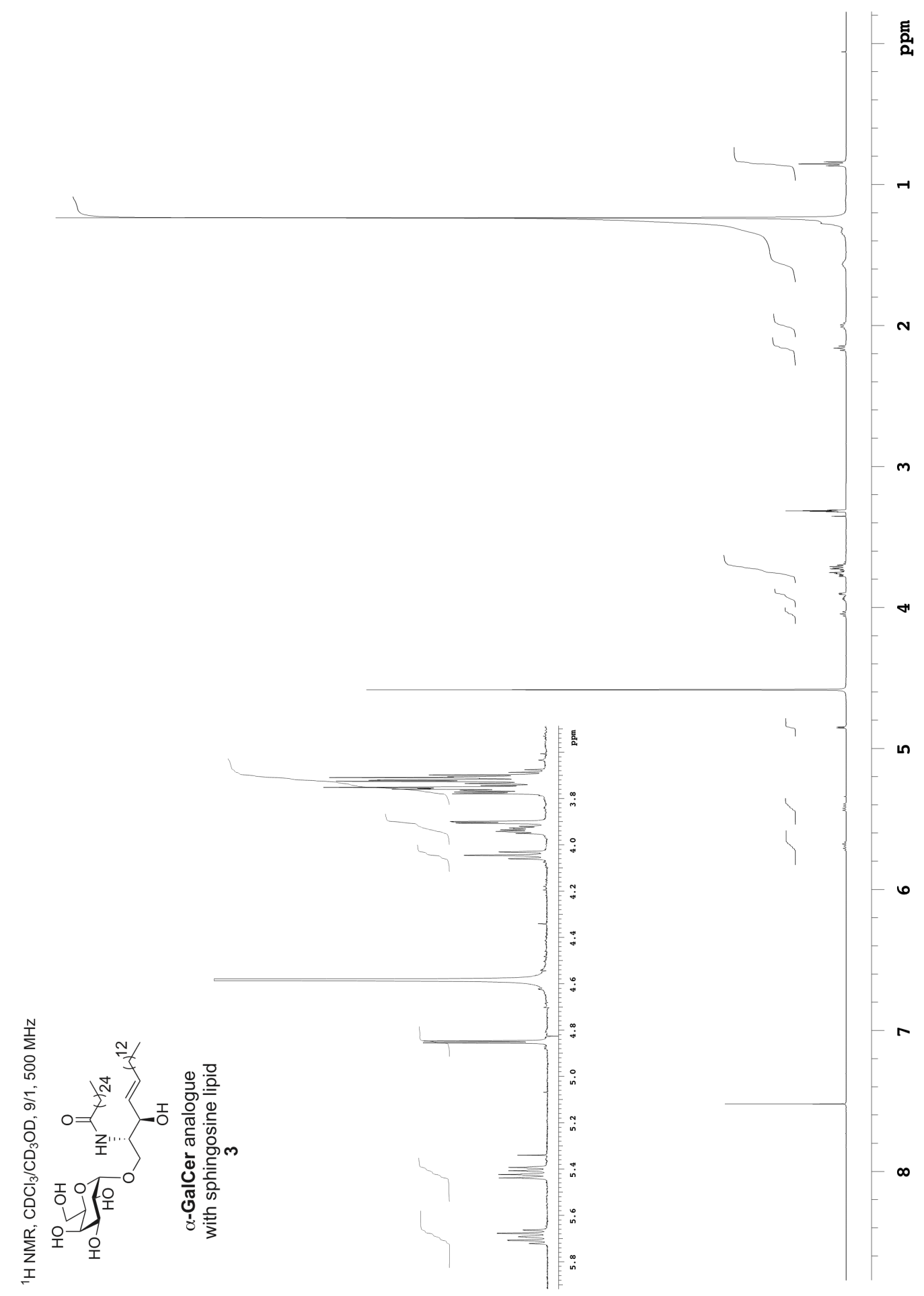


Chapter 4: Spectra of carbamate and primary alkenylamine

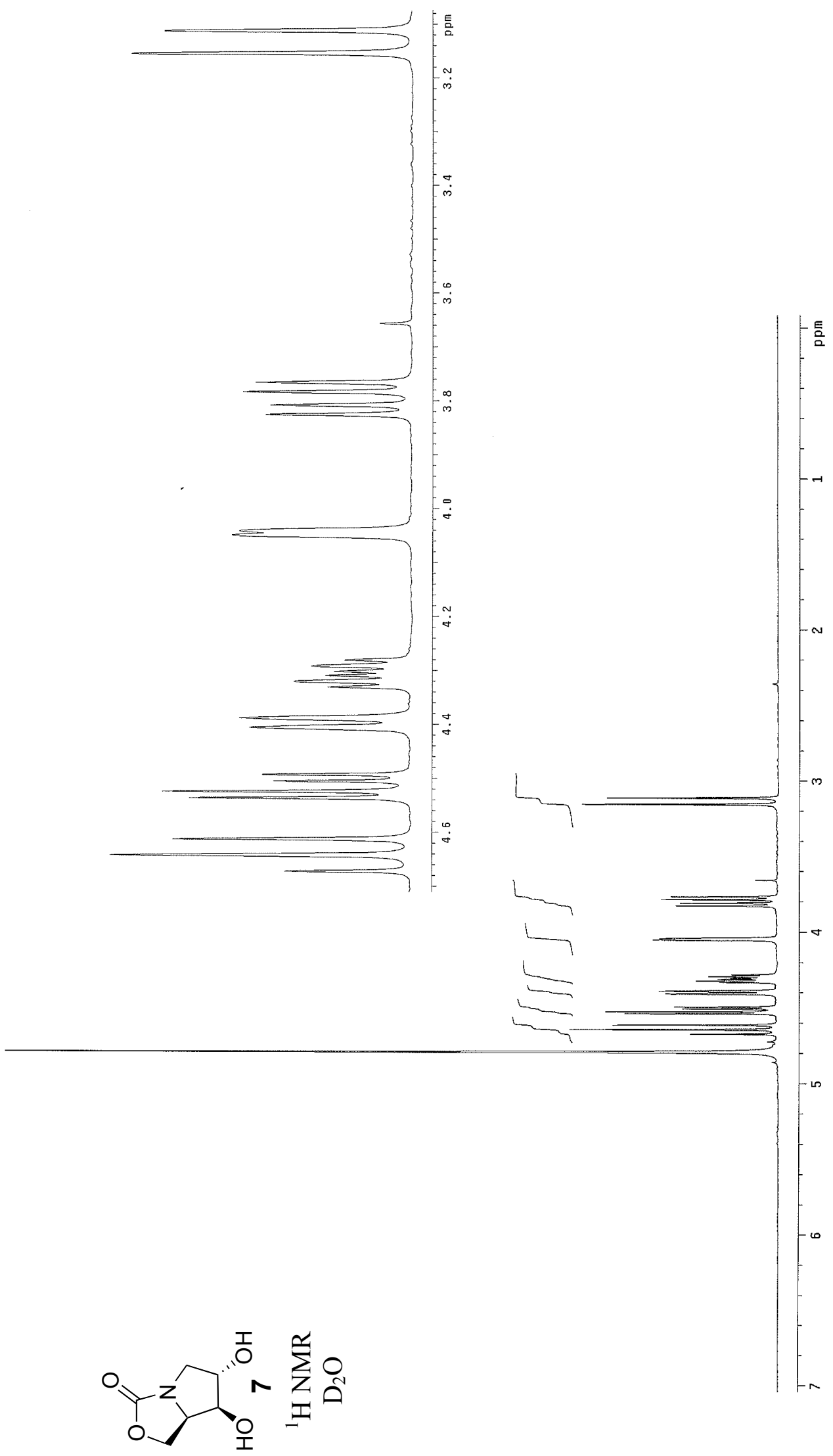




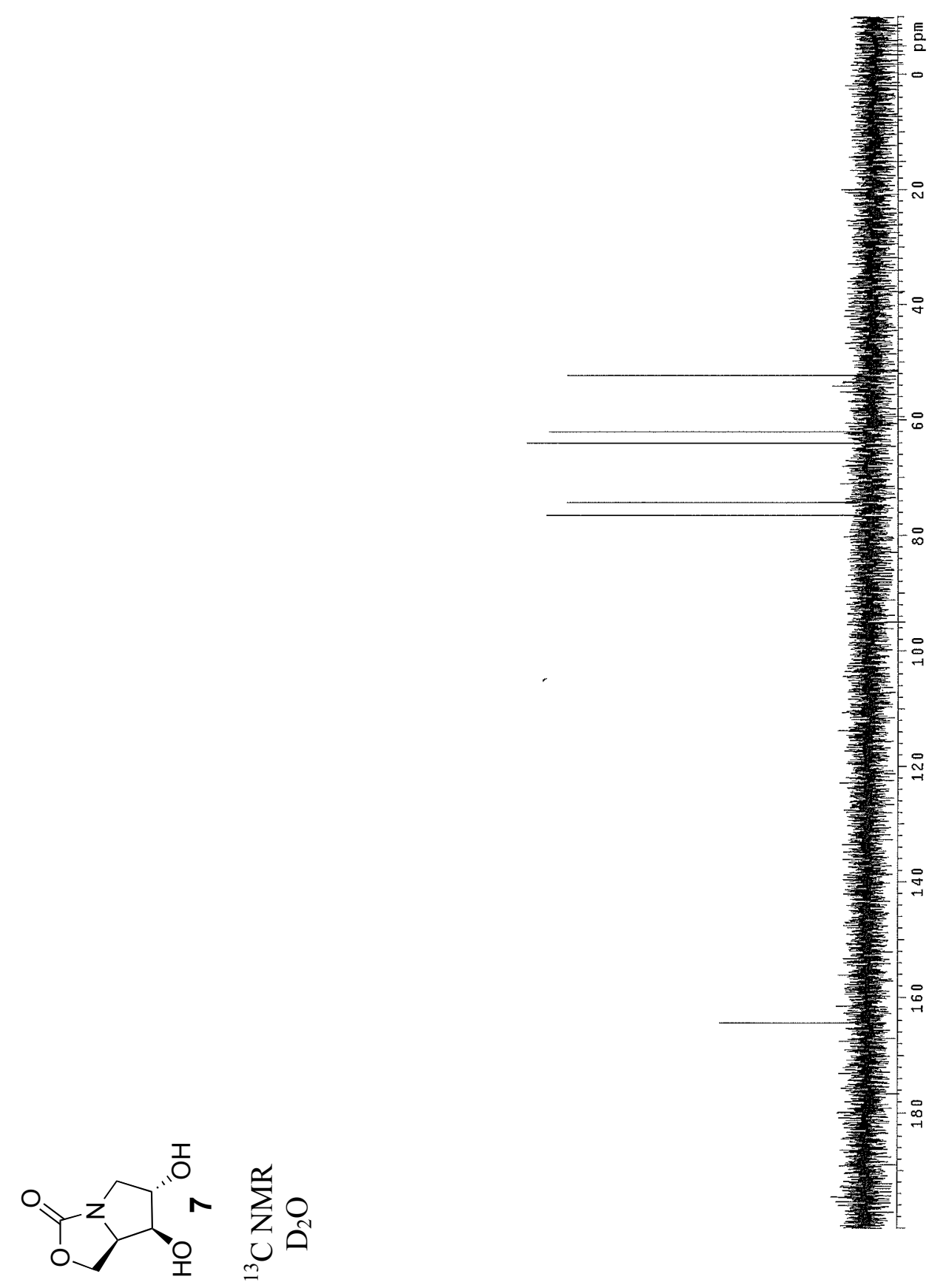




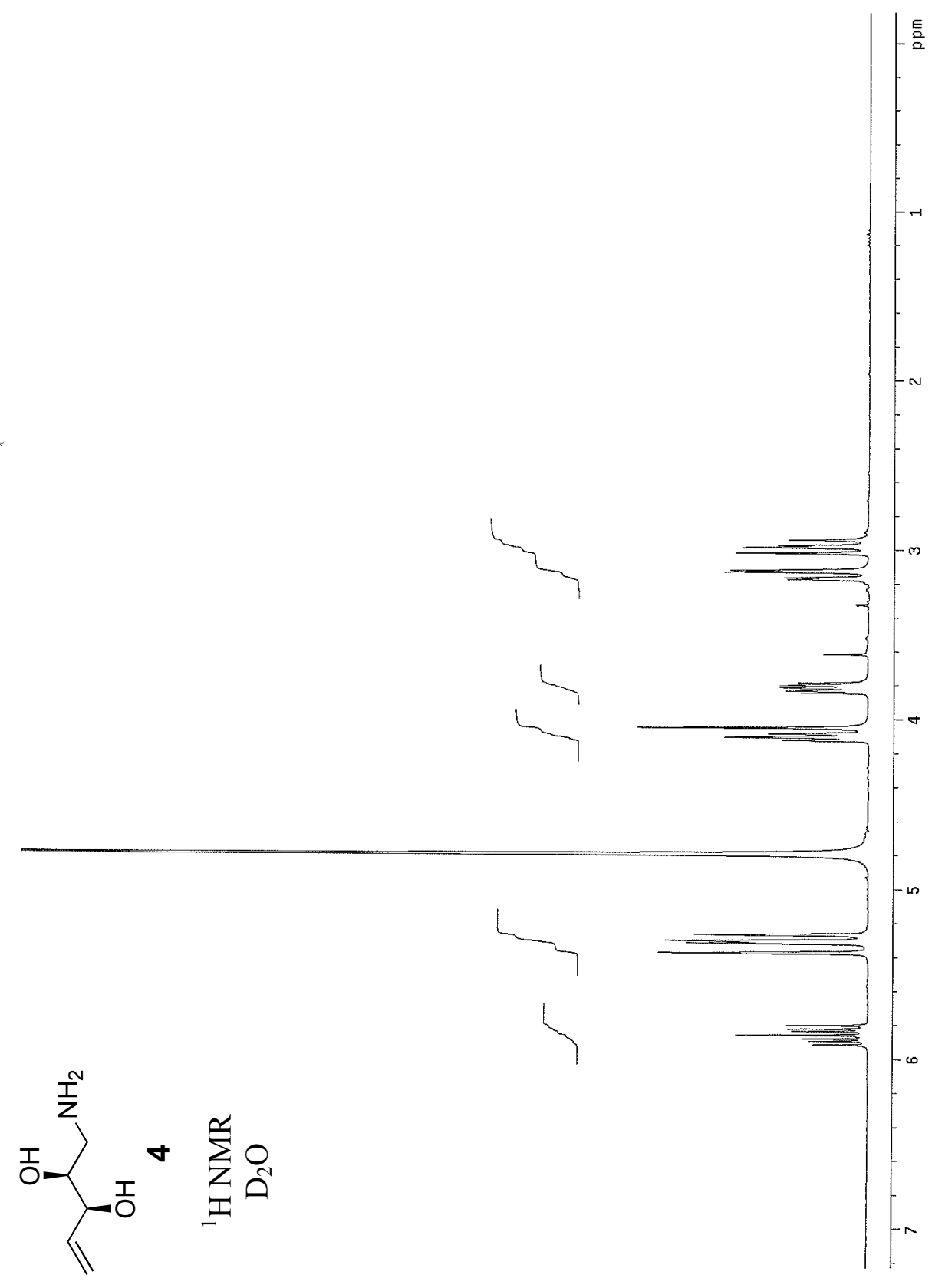

